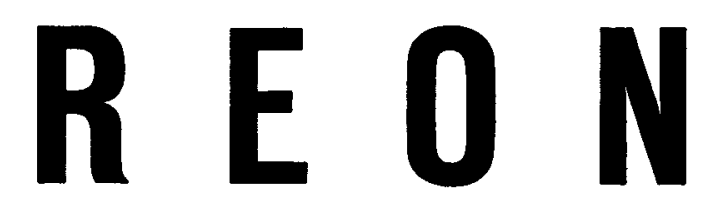

ROCKET ENGINE OPERATIONS - NUCLEAR

PROGRAM ACCOMPLISHMENTS - CONTRACT YEAR 1963

VOLUME II

RN-S-0014

30 OCTOBER 1963

SPACE NUCLEAR PROPULSION OFFICE

CONTRACT SNP-I

DISTRIBUTJON QE THIS DOCUMENT IS UNLIMITED

AEROJET

GENERAL TIRE

GENERAL 


\section{DISCLAIMER}

This report was prepared as an account of work sponsored by an agency of the United States Government. Neither the United States Government nor any agency Thereof, nor any of their employees, makes any warranty, express or implied, or assumes any legal liability or responsibility for the accuracy, completeness, or usefulness of any information, apparatus, product, or process disclosed, or represents that its use would not infringe privately owned rights. Reference herein to any specific commercial product, process, or service by trade name, trademark, manufacturer, or otherwise does not necessarily constitute or imply its endorsement, recommendation, or favoring by the United States Government or any agency thereof. The views and opinions of authors expressed herein do not necessarily state or reflect those of the United States Government or any agency thereof. 


\section{DISCLAIMER}

Portions of this document may be illegible in electronic image products. Images are produced from the best available original document. 


\title{
AERUJT-EENERAL CORPPARTION
}

$765: 726$

GLR: se

\author{
2. December 1963
}

\begin{abstract}
Space Nuclear Propulsion Office - Cleveland Extension National Aeronautics and Space Administration 21000 Brookpark Road

CIevelard 35, Ohio

At,iention: R.W. Schroeder, Chief

Subject: Supplemert to Report RN-S-0014 -- Program Accomplishments Contract Year 1963
\end{abstract}

Gertiemen:

During the CY 1.963 Contract status presentation at Cleveland, 30-31 October 1963, it was agreed that Aerojet would record and submit questiors and answers given in the course of the conference. In addition, some items were omitted from the printed report. Acrordingly, submitted as Enclosures (1), (2) and (3), are errata, omitted narrative material, and recorded questions and answers, respectively. It is requested that these be inserted intoncopies of Report, RN-S-0014 which were previously delivered to you.

Very truly yours,

AEROJET-GENERAI CORPORATION

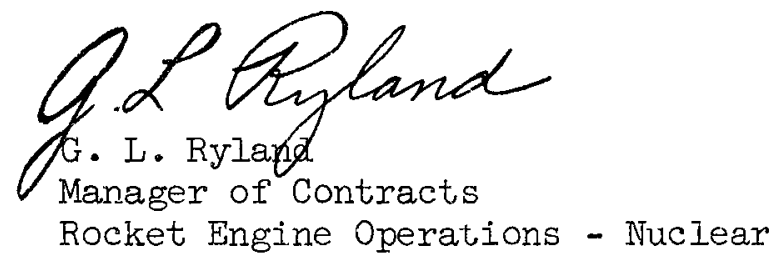

Eric losure:

(1) Eirrat,a Sheet to Report RN-S-0014

(i) Supplement to Report RN-S-00I4

(3) Questions and Answers

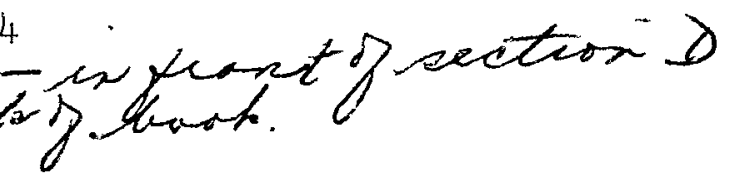


Enclosure ( 1 )

Page 2 of 2

ERRATA SHEET TO REPORT RN-S-0014

Correct the SNP-1 Cost Summary Chart in Section D of Volume II, as follows: CY 1963 PLART STATUS

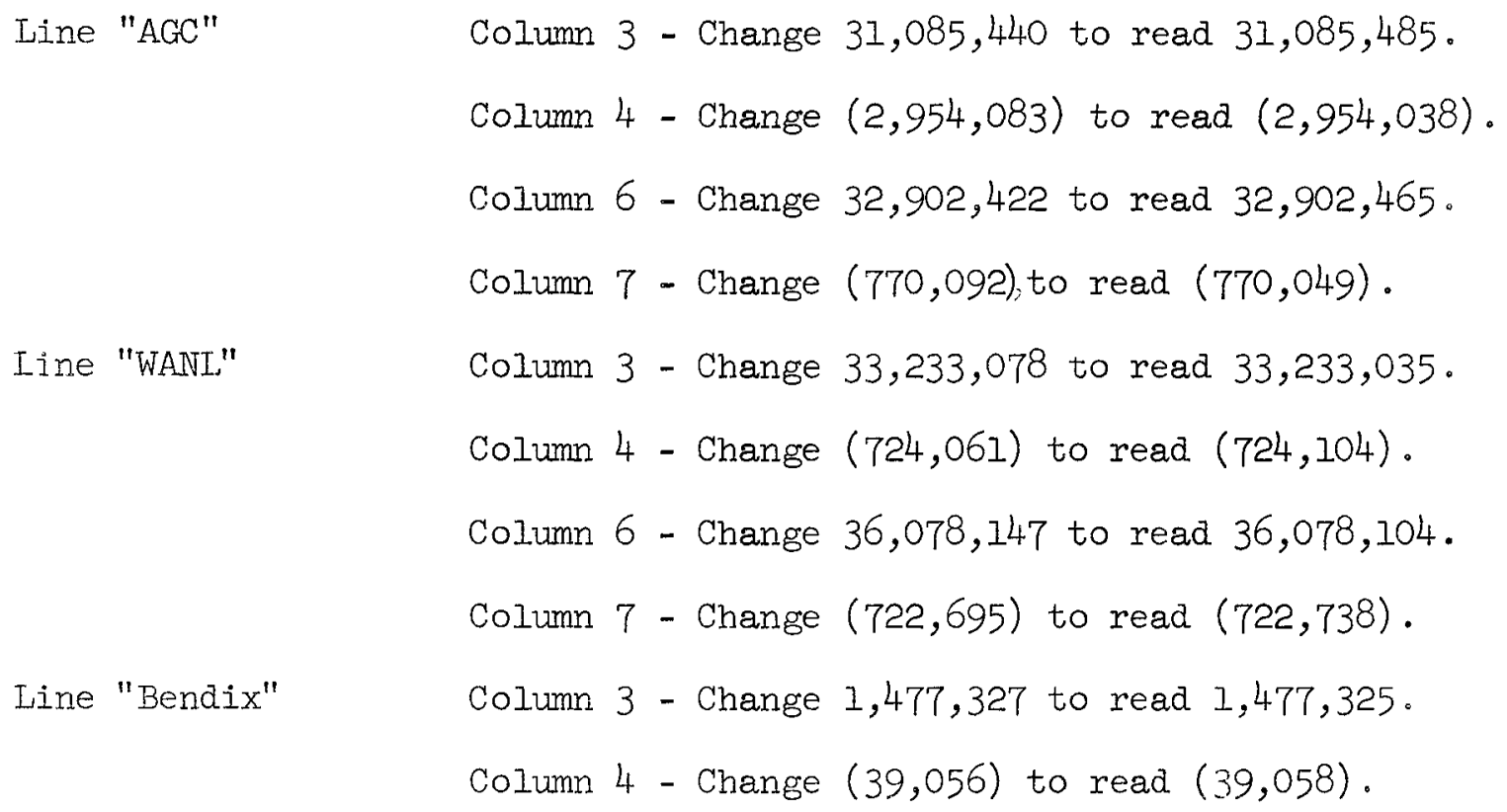

C.Y 63 STATUS

Line "Actual CY 63" Column 3 - Change 13,349,692 to read $73,349,692$. 
Thus report was prepared as an account of work sponsored by the United States Government. Neither the United States nor the United States Energy Research and Development Administration, nor any of their employees, nor any of their contractors, subcontractors, or their employees, makes any warranty, express or implied, or assumes any legal liability or responsibility for the accuracy, completeness or usefulness of any information, apparatus, product or process disclosed, or represents that its use would not infringe privately owned rights.

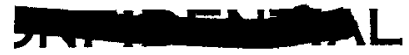

AEROJET 整:
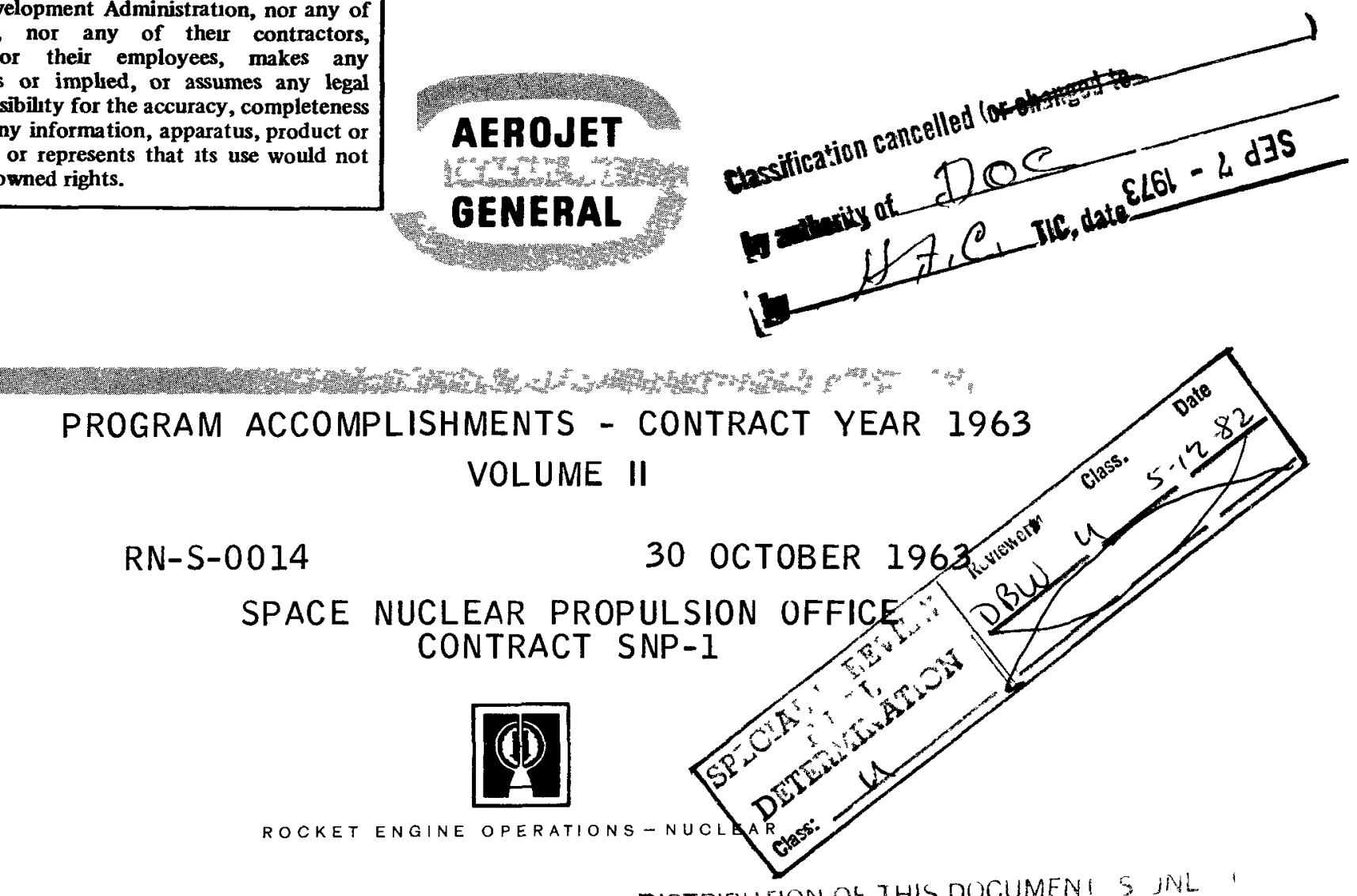

DISTRIBUION DE THIS DOCUMENI 5 JM

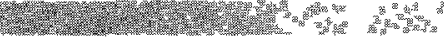

"This Document contains information affecting the National Defense of the United States within the meaning of the Espionage Laws, Title 18, U.S.C. Sections 793 and 794. Its Transmission or the Revelation of its contents in any manner to an unauthorized person is prohibited by Law."

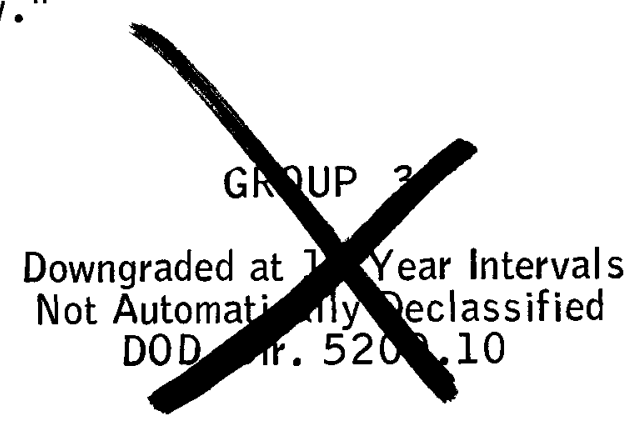

AGC Official Certifying Class. and/or Group

Indicate Name (Typed or Printed) Signature and Dept. No.

\section{AER OJET - GENERAL CORPORATION}

A SUBSIDIARY OF THE GENERAL TIRE \& FUBBER COMPANY 
PAGE BLANK 


\section{CONTENTS}

Volume I

A. CONTRACTUAL BACKGlioUnd MNIJ AFPRUACL

B. CALENJAR yeAR $190 j$ PROGRAM CBJWLLEVÉ

C. TASK $\triangle$ COOMPLISUMLNUS

(Subtasks 1.1 through 2.4)

Volume II

C. TASK ACCOMPLISHMENTS

(Subtasks 2.0 tin rough 0.2 )

D. SUMMARY

E. ESTIMATE TO COMPLETE CY 1903 WORK 


\section{S/T 2.6- PRESENTATION CHARTS CY63}

$W / s$

REFERENCE

2.6.1 RELIABILITY PROGRAM ACCOMPLISHMENTS

2-2.6.1

PLANNED

ACTUAL *

\begin{tabular}{|c|c|c|}
\hline $2-2.6 .1$ & $\begin{array}{l}\text { PREPARE A DETAILED RELIABILITY PROGRAM } \\
\text { PLAN \& SUBMIT TO SNPO-C PRIOR TO } \\
\text { FEB } 28,1963 \text {, FOR APPROVAL }\end{array}$ & $\begin{array}{l}\text { 1. RELIABILITY PLANS SUBMITTED TO SNPO-C } \\
\text { 2. REVISED RELIABILITY PLANS SUBMITTED } \\
\text { TO SNPO-C }\end{array}$ \\
\hline $2.6 .1(a)$ & $\begin{array}{l}\text { REVIEW PREVIOUSLY APPORTIONED RELIABI- } \\
\text { LITY GOALS } \xi \text { UPDATE AS REQUIRED } \xi \text { SUBMIT } \\
\text { TO SNPO-C FOR REVIEW }\end{array}$ & $\begin{array}{l}\text { 3. APPORTIONMENT - HOT BLEED ENGINE } \\
\text { 4. REVISED APPORTIONMENT - HOT BLEED } \\
\text { ENGINE COMPLETED }\end{array}$ \\
\hline $2.6 .1(b)$ & $\begin{array}{l}\text { REVIEW DWGS., SPECS., } \xi \text { OTHER PERTINENT } \\
\text { DOCUMENTATION DURING PERIOD FOR RELLABI- } \\
\text { LITY REQ'TS } \& \text { PREPARE MODES OF FAILURE ANAL }\end{array}$ & 5. DESIGN REVIEWS MOFA COMPLETED \\
\hline $2.6 .1(c)$ & $\begin{array}{l}\text { REVIEW TEST PLANS PEST PROGRAMS FOR } \\
\text { RELIABILITY REQUIREMENTS }\end{array}$ & 6. COMPLETED-RELIABILITY DATA BOOK \\
\hline $2.6 .1(d)$ & $\begin{array}{l}\text { ANALYZE TEST RESULTS } \& \text { TEST FAILURES } \\
\text { AND MONITOR FOR CORRECTIVE ACTION }\end{array}$ & 7. COMPLETED-RELIABILITY DATA BOOK \\
\hline $2.6 .1(e)$ & $\begin{array}{l}\text { COLLECT \& ANALYZE RELIABILITY DATA } \\
\text { AND RECORD RELIABILITY INFORMATION }\end{array}$ & $\begin{array}{l}\text { 8. RELIABILITY DATA HAS BEEN } \\
\text { COLLECTED \& ANALYZED COMPLETED }\end{array}$ \\
\hline$-3.3(a)$ & $\begin{array}{l}\text { IMPLEMENT A SUPPLEMENTARY EFFORT } \\
\text { TO MONITOR } \xi \text { MAINTAIN SURVEILLANCE OF } \\
\text { THE RELIABILITY ACTIVITY OF EG } \$ \text { G }\end{array}$ & $\begin{array}{l}\text { 9. EG } \text { G G RELIABILITY PLAN HAS BEEN } \\
\text { APPROVED } \\
\text { 10.CRITICAL ITEMS LIST PREPARED }\end{array}$ \\
\hline
\end{tabular}

* EVIDENCE OF COMPLETION IS SHOWN IN DOCUMENTATION LIST INCLUded IN HANDOUT 


\title{
S/T 2.6 PRESENTATION CHART CY '63
}

W/S

REFERENCE $\quad$ PLANNED

\subsection{RELIABILITY PROGRAM ACCOMPLISHMENTS}

\author{
MISC ACCOMPLISHMENTS \\ 11. NPC 250-I INCORPORATED IN RELIABILITY \\ PROGRAM PLAN \\ 12. MATHEMATICAL MODEL FOR SIMULATION \\ AND PREDICTION OF THE RELIABILITY \\ OF THE NERVA ENGINE \\ 13. RELIABILITY ANALYSES REPORTS \\ HAVE BEEN PREPARED \\ 14. MATHEMATICAL MODELS DEVELOPED \\ FOR RELIABILITY PREDICTION OF NON- \\ NUCLEAR ASSEMBLIES AND COMPONENTS
}

* EVIDENCE OF COMPLETION IS SHOWN IN DOCUMENTATION LIST INCLUDED IN HANDOUT 


\section{S/T 2.6 PRESENTATION CHART CY'63}

\begin{tabular}{|c|c|c|}
\hline \multirow{2}{*}{$\begin{array}{c}W / S \\
\text { REFERENCE } \\
2-2.6 .2(a)\end{array}$} & \multicolumn{2}{|c|}{ 2.6.2 QUALITY ASSURANCE PROGRAM ACCOMPLISHMENTS } \\
\hline & $\begin{array}{l}\text { PLANNED } \\
\text { CONDUCT A QA PROGRAM IN ACCORD } \\
\text { ANCE WITH NPC 2OO-2 AND } \\
\text { 2OO-3 AS INTERPRETED BY NOPPS } \\
\text { IV. B. I DURING PERIOD IOCTOBER } \\
1962 \text { THROUGH } 31 \text { MARCH } 1963\end{array}$ & $\begin{array}{l}\text { ACTUAL * } \\
\text { 1. QA PROGRAMS STARTED } \\
\text { 2. INSTRUCTIONS PREPARED FOR E QA PROGRAM } \\
\text { PLAN } \\
\text { 3. REON RE, QA PLAN SUBMITTED } \\
\text { 4. MTGS. WITH AGC \& SUBCONTRACTOR PLANTS } \\
\text { 5. REQQA PROGRAM PLANS SUBMITTED FOR LRP, } \\
\text { WANL, AMF, BENDIX } \\
\text { 6. ESTABLISHED PROD. ASSURANCE DIVISION } \\
\text { 75 MARCH I963 } \\
\text { 7. MONITORED REQA PERFORMANCE }\end{array}$ \\
\hline $2.6 .2(b)$ & $\begin{array}{l}\text { EFFECTIVE } 1 \text { APRIL } 1963 \text {, CONDUCT } \\
\text { A R \& QA PROGRAM IN ACCORD- } \\
\text { ANCE WITH NPC 200-2 AND 200-3 } \\
\text { AS INTERPRETED BY REON RE2QA } \\
\text { PROGRAM PLAN, REPORT } * 2487\end{array}$ & $\begin{array}{l}\text { 8. REVIEWED QA PLANS W SNPO-C } \\
\text { 9. COORDINATED REVISIONS WITH RESPECTIVE } \\
\text { PLANTS } \\
\text { 10. REVISED QA PLANS SUBMITTED TO SNPO-C } \\
\text { 11. ESTABLISHED FIELD SURVEILLANCE OFFICES } \\
\text { 12. REVISED REON R E, QA PROGRAM PLAN } \\
\text { 13. ORIENTATION } \varepsilon_{2} \text { INTRODUCTION PROGRAM } \\
\text { 14. QA IMPLEMENTATION SCHEDULE ESTABLISHED } \\
\text { 15. PREPARED RE. QA PROGRAM PLAN FOR NTO } \\
\text { 16. NRX-AI FACTORY TEST PLAN E PROCEDURES } \\
\text { 17. IMPLEMENTATION OF RE Q QA ACTIVITIES } \\
\text { 18. ESTABLISHED COMPREHENSIVE AUDIT SYSTEM. }\end{array}$ \\
\hline & MONITOR QA ACTIVITIES OF EG $\varepsilon_{2} G$ & 19. EG \& QA PLAN REVIEWED \\
\hline
\end{tabular}

* EVIDENCE OF COMPLETION IS SHOWN IN DOCUMENTATION LIST INCLUDED IN HANDOUT 


\section{SUBTASK 2.6 - ACCOMPLISHMENTS CY 1963}

Purpose and Objective

The overall objective of Subtask 2.6 was to ensure that the subsystems, components and related support equipment designed and built during CY 1963 achieved the required reliability and quality.

There are over 100 significant program activities which directly affect product reliability or quality and for which the Reliability and Quality Assurance organization has primary or associate responsibility. The Reliability and Quality Assurance supervisory and engineering input to these activities are supported by Subtask 2.6. The accomplishments under Subtask 2.6 probably could be demonstrated most effectively by presenting the status and problems associated with the implementation of each of these activities. Also, I am sure the presentation of slides or charts illustrating some of the more significant accomplishments in these activities, such as reliability apportionment diagrams, growth curves, prediction models, etc., would be of interest. However, allotted time for this presentation will not permit detailed discussion of each of the reliability and quality assurance activities, although I will be glad to provide any information desired on specific items of interest. Reliability and quality methods, charts, graphs, etc., are available in the plans, data books, reports and other documentation which have been submitted to the SNPO-C Reliability and Quality Assurance group.

My presentation will be based on the flip charts which include the program objectives, and a very brief statement of actual accomplishment of these objectives. Program plans, data books, reports and other documentation bearing evidence of completion of these accomplishments is given in the bibliography included in the handout. Also, a copy of this narrative report and the Milestone Chart for 2.6 is given, showing completion of all milestones during 1963. I will briefly expand on the accomplishments in order to explain their significance.

A Reliability Program Plan, REON Report No. 2487, was submitted to SNPO-C for approval in February, 1963. Reliability Program Plans were prepared also by LRP, WANL, AMF, and Bendix and submitted to SNPO-C for review. These plans were reviewed by Lewis Research Center - Reliability, SNPO-C, and REON Product Assurance Division. Comments resulting from these reviews have been incorporated into revised editions of the plans.

$$
2.6-1
$$


A complete apportionment of reliability - based on actual or calculated failure rate data and assuming $80 \%$ reliability for the E-7 engine test - was prepared during the previous Contract Year for the heated-bleed engine. This apportionment was revised to meet the configuration of the hot bleed engine and was included in Report No. 2469, Volume 1. The latter has been reassessed and revised to update and to include all additional reliability information and will be included in Report No. 2487, Revision (a).

$\underline{2-2.6 .1(b)}$

All designs - specifications, drawings, standards - have been reviewed by Reliability as released. Modes of failure analyses - giving mode, cause, effect and probability of failure and the corrective action required - was prepared on all critical assemblies, subassemblies or components. Results of design reviews and modes of failure analyses are reported in the LRP Reliability Data. Book and WANL technical reports.

$\underline{2-2.6 .1(c)}$

All test plans and test programs published during the Contract Year have been reviewed by Reliability Engineering, and the reliability input has been included in the final plans. Reliability test plan reviews appear in the LRP Reliability Data Book and in WANL technical reports.

$\underline{2-2.6 .1(a)}$

Test results have been analyzed by Reliability Engineering. All test failures have been analyzed and failure reports and corrective action reports have been issued in accordance with the failure reporting corrective action system developed in each plant. Failure reports are filed in the Reliability Data Book, and summaries of failures and corrective action appear in the Reliability and Quality Assurance supplement to the Informal Monthly Progress Letters.

$\underline{2-2.6 . I(e)}$

All pertinent reliability data generated during the Contract Year have been collected, maintained, analyzed and reported in accordance with the data system established in each plant. Summary data required for the reliability assessment of the NERVA engine is collected, maintained, analyzed and reported $b_{J}$ the REON Product Assurance Division.

$$
2 \cdot 6-2
$$


In accordance with C.O. No. I for Mod 8, a Reliability Program Plan has been prepared by EG\&G for the ETS-I I\&C equipment and approved by REON and SNPO-C. However, this program is limited to critical items. A critical item is defined as an item the failure of which would:

(1) Adversely affect the safety of personnel.

(2) Result in significant loss of test data.

(3) Result in facility or engine damage that would cause excessive schedule delay.

A critical items list has been prepared by REON Engineering and Product Assurance and transmitted to SNPO-C for approval.

In addition to the above, other reliability accomplishments include the following:

(a) REON Reliability Program Plan, Report No. 2487, is being revised to incorporate the applicable requirements of NPC 250-1, which is to be incorporated into the 2.6 Work Statement for Contract Year 1964. Target date for the issue of revision (a) to this plan is 15 November 1963.

(b) A system for the simulation and prediction of the reliability of the NERVA engine is under development. This system involves the establishment of mission phases, environmental and operating conditions for each phase, time sequenced events required for mission success, specific hardware associated with each event, a mathematical model for assessing, reliability, including redundancy available, and a Monte Carlo computer program for reliability simulation. This system will be included in revision (a) to REON Report No. 2487.

(c) Numerous statistical studies have been made for use in the reliability analysis of nuclear and non-nuclear components. Examples of the studies made during the contract Year are given in the documentation list.

(a) Mathematical models have been developed for computing the reliability of all non-nuclear components and assemblies of the NERVA engine. These models are in the Reliability Data Book and will be used for reliability assessments as reliability date is generated. 
$2-2.6 .2(a)$

Prior to 1 October 1962, a quality control program was conducted in all AGC and subcontractor plants, in accordance with local quality control manuals and guidelines established by REON. This program met most of the requirements of NPC 2002- except that the level of quality control applied to experimental, test and ground support equipment was left up to the cognizant design or test engineer。

On October 1962, NPC 200- $\hat{c}$ was included in the Work Statement. It was agreed by REON and SNPO-C that the quality program during the period 1 October 1962 through 31 March 1963 would be limited to those NPC $200-2$ requirements as interpreted by NOPPS IV-BI. The latter document limited the program to approximately the program in effect during CY 1962. It was further agreed that during this period a quality program plan would be prepared, to be effective 1 April 1963, which would extend a.l applicable provisions of NPC 200-2 and NPC 200-3 to all NERVA hardware including experimental, STE, GSE, and to all ticrs of suppliers. This was a momentous decision, as it extended the quality control coverage to experimentaI laboratories, development nachine shops, test areas, facility and tool design and certain suppliers which previously had not been subjected to this level of control. Ihis created a serious indoctrination and tralning requirement in the extended areas and a serious stafiing problem for the Quality Control Departments.

In order to comply with the above requirements, NOFPS IV-BI was revised and negotiated with SNPO-C. Elaborate instructions for preparing definitive quality program plans were issued to all AGC and subcontractor plants. Numerous meetings, conferences and communications were required to obtain plans from the several plants and to obtain agreement of plant managements.

The REON Reliability and Quality Assurance Program Plan, Report No. 2487, incorporating program plans for LRP, WANL, AMF and Bendix were submitted to SNPO-C on schedule prior to 28 February 1963. A Product Assurance Division was established in REON in March 1963 to establish and monitor the NERVA Reliability and Quality Assurance Program in accordance with this plan. Considerable effort was expended to get all plants in shape to implement the program plan. 
The plans, submitted above, were reviewed with SNPO-C. In general, they were found to be satisfactory except for areas requiring further clarification and certain compromises which were not acceptable. Desired changes were negotiated with plants concerned, and Revision (a) of the LRP, WANL, AMF and Bendix Plans were resubmitted for SNPO-C review. The revisions have been found satisfactory, with the exception of minor editorial comments, except for the WANL Plan, which still has a few items of omission and a few items requiring change or clarification. WANL has been notified of changes required. Now that the plans for the AGC and subcontractor plants have been substantially finalized, the REON Reliability and Quality Assurance Plan is being revised to incorporate any significant changes that have been agreed to and to directly incorporate all Reliability and Quality Assurance contractual program requirements. This will be submitted to SNPO-C for final approval on 15 November 1963.

No matter how adequate the plan, no improvement in quality will result unless every person affected by the plan understands it and follows it. Consequently, the second phase of a Reliability and Quality Assurance program is the orientation and indoctrination of personnel affected. The Reliability and Quality Assurance Program affects almost everyone on the NERVA program, and so this is a herculean task. Plans have been distributed widely, and considerable effort has been spent in determining that pertinent personnel are informed as required regarding the provisions, methods, systems, procedures, etc. included in the plan.

The third step in a Reliability and Quality Assurance Plan is the implementation of the designated activities. Since the plan went into effect on 1 April 1963, it could not be expected that each of the 100 activities could be fully implemented and 100\% effective immediately. Each activity was appraised in each plant and implementation schedules were obtained for those items requiring implementation.

Field surveillance offices were established at WANL and LRP." The present status of implementation might be summarized as follows: almost all of the 100 required activities have been implemented to some degree in every plant. The majority of these items have been implemented to a satisfactory 
level in each plant. Some of these items have been satisfactorily implemented for certain types of hardware, but not for others. The weakest hardware areas are still the special test and ground support equipment and experimental hardware made in development labs and shops. Probably the most vulnerable area in this category in all plants has to do with specifications. Existing Industrial and Government specifications and standards are not definitive to the extent that they can be used for the acceptance or rejection of hardware on a black-or-white basis. These specifications have been previously used, expecting that with certified processes, certified operators and certified inspectors, technical judgement would be used in those areas that required further interpretation and that any questionable areas would be covered by proper Material Review Board actions. If specifications are required to be completely definitive, either excessive time must be spent in the review of each procurement package or there must be a complete set of definitive specifications written specifically for the NERVA program. In order that the review of procurement packages be implemented fully and effectively, criteria as to the degree of definitiveness of specifications will have to be evolved.

An audit system has been prepared through which the effectiveness, completeness, efficiency, conformance to policy and status of corrective action will be determined on a current basis for each of the 100 reliability and quality assurance activities in each plant on a current basis. This system will also provide a numerical rating for the implementation of reliability and quality assurance activities for each plant and the overall program.

A Reliability and Quality Assurance Program Plan for the NERVA Test Operations at NRDS has been prepared and will be submitted to SNPO-C for revicw by 15 November 1963. Also, a factory test plan which designates the control points during the assembly of the NRX A-I test at NRDS and the inspection procedures for each control point has been prepared and submitted for review.

$13-3 \cdot 3(\mathrm{a})$

Several EG\&G Quality Control plans have been reviewed and comments submitted to EG\&G and SNPO-C. The last plan submitted to EG\&G is somewhat improved, but is not completc and lacks derinition of detailed procedures. 
In summary, during Contract Year 1963, we have developed Reliability and Quality Assurance Program Plans which are substantially complete and satisfactory. Personnel have been oriented and indoctrinated as to the requirement and provisions of these plans to a large extent. Most of the reliability and quality assurance activities have been implemented to a satisfactory level. Remaining action is to extend the coverage and to improve the effectiveness and the efficiency of these activities. This will be accomplished by a comprehensive audit-corrective action system. 


\section{SUBTASK 2.6 - BIBLIOGRAPHY}

Ia a REON Report 2487 - REON Reliability and Quality Assimanco Program Plan, Sebruary 1963

bo IRP Report $\# 2469$ - R \& QA NERUA Program, Vol. I (Reliability Program Plan), February 1963

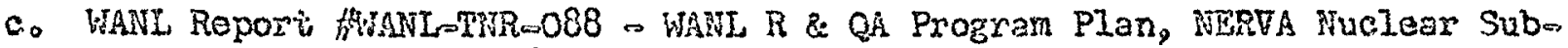
system, 31 January 1983

do AM Atomies Report o $\mathrm{R}$ \& QA Program Plang NFRVA Renote Handing System, 6 February 1963

e. Bendix Report fHBAD 4909 o The Bendix NERVA Progran, $n$ is Qh Progran Plan, 8 Fémuary 2963

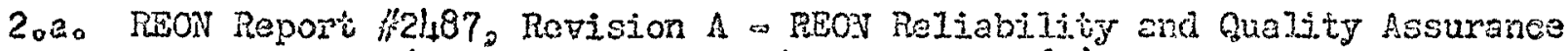
Progian Plan (to bo published 15 Novomber 1963)

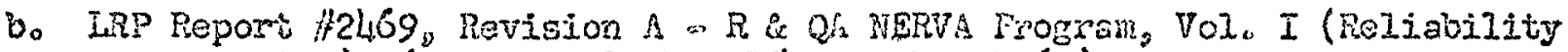
Program Plan), (to be publishea 15 Nuvember 1963)

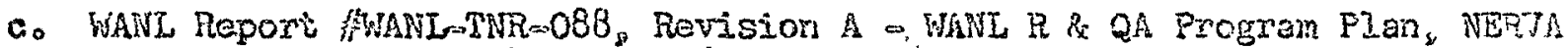
Nuclear Subsystem, 24 june 1963

d. ARF Atomics Report, Rev。 $I$ - $R$ \& QA Program Plan, WERVA Remote Handing System, 22 August 1963

e. Bendix Report thPAD 4909, Revision $B$ o The Rendix NERVA Program, $R$ Re $Q A$ Program Plan (Reliability) 30 August 1963

30 Exhibit IVw1 - LRP R \& QA Program Plan, Volume 1, February 1963

4. Exhibit in REON Report 42487 , Revision A - REON R \& QA Program Plan, (Co be published 15 November 1963)

5oa. $R$ \& QA Supplenents to REON Informal Plonthly Frogress Letters No. 22 through 27 sor NERVA Program, April through Sepuenber 1963

b. LRP NERVA Reliability Data Bock (continuous)

co REON Report (as yet unpublished) corresponding to REON TM 739-63-103 Report on Actuator Bvaluation did 10/10/63.

d. WANL Repor't WANL TWR 085 a Failure Mode Analysis Summary, NERVA NRX $\odot$ Reactor, 3 Kareh 1963

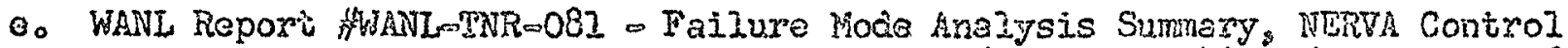
Drum Actuator Proposed by General. Electric (Fodel AGol4), 25 January 1963

1. WANL Report IWAMLINR=082 - Failure Pode Analysis Sunmaxy, NERTA Control Drum Acicuator Proposed by Bendix (Kodel NDoDI), 15 Jenuary 1963 
Documani List $=2.6 .1$ Reliability Prograin (continued)

6.a. $\mathrm{A}$ \& QA Supplements to REON Informal Ponthly Progress Letters No. 22 through 27 for NERVA Program, April through September 1963

bo LRP NERVA Reliability Data Book (continuous)

c. WANL Report $\frac{1}{\pi}$ WANL-TNR=095 - NRX-A Cornponent Test Program, 16 April 1963

d. WANL Report fWANL-TNR-097 - NRX $-A I$ Test PIan, Revision I, May 1963

7oa. A is QA Supplements to REON Informal Monthly Progress Letters No. 22 through 27 for NERVA Program, April through September 1963

b. LRP AERTA Reliaojlity Data Book (continuous)

C. Bendix Report HBPAD 863-4=25022R - Turbine Power Control Valve Actuator

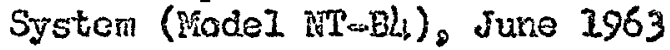

8.a. R \& QA Supplements to REON Informal Monthiy Progress Letters No. 22 through 27 for WERVA Program, April through September 1963

bo IRP NERVA Reliability Data Book (Continuous)

c. Bendix Report BPAD 49-14995R - Statistical Distribution for Reliability Frediction, 2 July 1953

d. AGC Repost \#2258 - Reliability Concepis, Vol. I of Reliability Handbook, April 1962

0. AGG Report HCRA62-2 - Reliability Nethods" Vol II of Reliability Hondbook (Corporate)

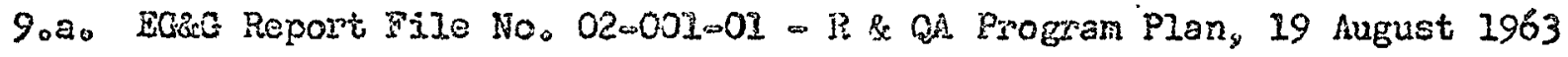

bo ERgG Report File No. 02000i-12 - R R QA Program Plang 29 August 1963

10. Itr. fiom W D Stinnett to $R$ W Schreeder did 6 September 1963. Subject: Ciritical Ftem List, $R$ \& OA Program, FirS-1 I \& $G_{9}$ I741:0302, Subtask 3.3

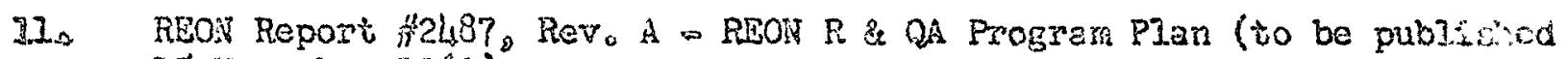
15 Noveniber 7963)

12. REON Report H2L87\% Rev。A = REON $R$ \& QA Program Plan (to be published 15 November 1963)

13.a. REON Merno 736:0184 w Statistical Tolerance Study of the Bal Fuel Element With Respect to the CrossoSectional Area of the Core, 29 March 1963

b. REON Memo 736:0167 - Statistical Iclerance Study of the Bal Fuel Elemont, 12 March 2963

0. REON Mero 736:0208 - Study of Using Uadersize Fuel Elements for a Portion of the Core, 23 May 1963

d. REON Remo 736:0232 - Reliability Companison of Relay vg Solid State Cirouitry

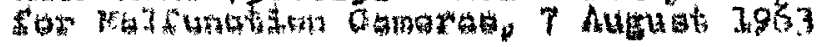




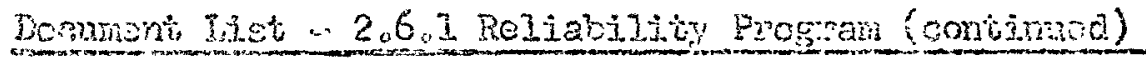

13.0. MECN Romo 736:0203 or Reliability Compazison Between Two Anti-criticality Destruet Systems, 14 May 1963

$I_{0} \cdot \mathrm{REO}_{4}$ Memo 736:0212 - Reliability Study "Evaluation and Comparison of Attitude Control System for Spacecrait With NERVA Engines, 3 June 1963

3ho LRP NERVA ReIiability Data Book (continuous)

Docunert List $=2.602$ Quality Assurance Program

I. MOPPS TV $-B$ - NERTA NASA Quality Provisions NPC 200.2 and NPC $200-3$ dated 17 july 1962

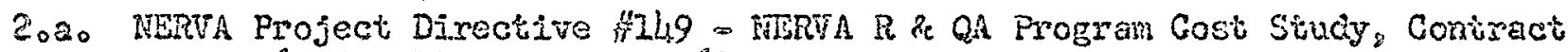
Task 2.6, did 13 Decenber 1982

D. Enclosuxe I of $P_{0} D$. 149 - HOPPS IV=El Revision (a) a NERVA NASA Quality Provisions (NPC 200-2 and NPC 200-3) dated 15 November 1962

Go Bhelosure 2 of P.D. 149 - HOPPS JNaA, Revision (a) o NREVA Raliability and Gualtity Assurance Program, did 7 Decomber 1962

d. Enclosure 3 of P.D. 149 o Quality Assurance Program Plan Outiline

3o PEON Report H2L87 - PRON R \& QA Progian Plan, February 1963

Lo Minutes of Meetings, Letiers to Subconiractors, etr.

5.a. IRP Beport $\# 2469$ - $R$ \& QA NERVA Programi Vol. II (Quality Assuronee) Feb。 1963

b. WANL Report thaNL mINR 088 - WANL R R QA Progtam PIan, 31 january 1963

c. Eendix Repont fBPAD 4999 - The Bendix IVERVA Program, $R$ \& QA Progran Plan, 8 February 1963

d. AMF Atomics Report = $\mathrm{R}$ \& QA Frogram Plan, NERVA Remote Handing Sysiom 6 February 1963

6. Itr. Ixom 6 House to Corporate Offices and Stanf, Plant and Division Ianagers, Depariment Heads, Supervisors o A11 Planis, citd 15 March 1963, re: Establishment of REON Product Assurance Division

7. Mnutes of Technical Direction Meetings, Trip Roports \& Other Conrespondenee

8.a. Various Review Meeting Reports

bo Program Plan Checklisis

9. Letters to Planis from REON Subcontracts Division, Minutes of Meotings, and Technical Direction Meetings

10.2. LRP Report fithóg, Vol. II, Revo $A=R$ \& QA NERVA Program (Quality Assurance Program Plan), April 1963

$$
2.6-3 a
$$


Document Ijist - 2.6.2 Quelity Assurance Program (continued)

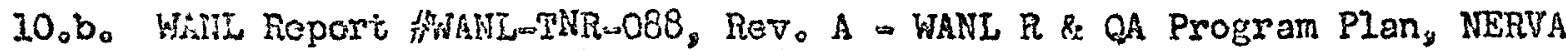
Nuclear Subsystem, 24 June 1963

c. Eandix Report fBPAD 49-9, Rev。A $-\mathbb{R}$ \& QA Program Plan (Quality Assuranco), 30 August 1963

d. ANF Atomics Renort o R \& QA Rrogran Plan, Revision $I_{3} 22$ August 1963

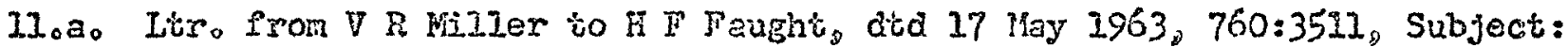
Subcontract NPol o REON Reliability and Qualitiy Assuranee Office at WANL

b. Correspondence, Management Mectings, Technical Direction Meatings, and Organization Nanuals

12. REON Report M248?, Rev。 A $\propto$ PEON R \& OA Program Plan (to be published 15 November 1963

13. Management Meetings, Seninars, Technical Direction MeetIngs, Project Directives, Training Manuais, Procedures and Correspondenco

14. Implenentation Dates Incicated on Program Elenent Chart for Each Plant Contained in $R$ \& $Q A$ Pians

15. Nevada Tesi Operations $R$ \& QA Program Plon to be publikhod 15 November 2963

16. NRX $=$ A1 Factory Test Plan $\infty$ Procedures Lol through Loldg Lo8 through Lall, L=13, Wo5 through Wo7, Wol2, Woll, Nols through No33, 23 June 1983

37.a. Reliebility Data Books

D. Reports (Reliability, Corrective Action, Audits, Survey, Quality Control)

C. Documantation (Design, Procurement, Fabrication, Quality Control)

d. Projeci Directives and Comespondence

18.a. REON Report $\$ 2487$. Rev. $A=$ REON $R$ \& QA Program Pian (to be published 15 November 1963)

b. AGG Quazity Control Instruction Manual

C. ACC Corporate Qualicy Control Poliejes \& P cedures Manual

d. AGC Corporate Qualitiy Control Standards Mamual

19.2. EG\&G Repont File No. O2. DOL-18 a \& QA Plan, 1 October 1963

b. AGG Iitr. From $D$ I Dering to $\mathrm{J} W$ Dutili, $720: L 173$, did 22 October 1963, re: EC\&G QA Program Plan

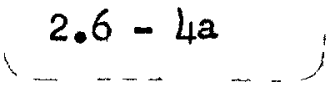




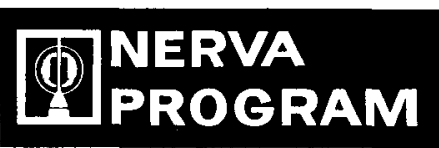

SCHEDULES AND MILESTONES

CONTRACT YEAR 1963

TASK ITEM 2.6

县

RELIABILITY \& QUALITY
ASSURANCE

1962

1963

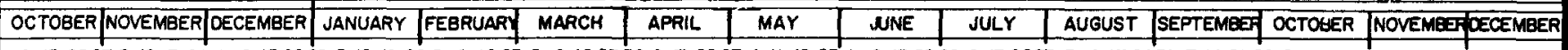

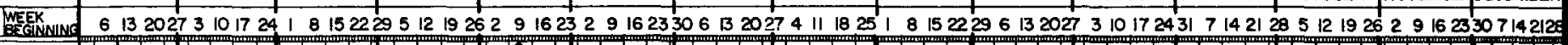

1. SUBMIT REON RELIABILITY \& QUALITY ASSURANCE KREPORT №. 2487) TO SNPO-C

2. IMPLEMENT APPROVED RELIABILITY \& QUALITY ASSURANCE PROGRAM PLAN

3. ISSUE NRX-A REACTOR FAILURE MODE ANALYSIS REPORT (M) 4. COMPLETE NRX DESIGN REVIEW (W) 5. COMPLETE DESIGN REVIEW FOR EXPERIMENTAL BENDIX ACTUATORS (BPAD)

6. COMPLETE 1St RELIABILITY ASSESSMENT FOR NON-NUCLEA ENGINE (LRP)

7. COMPLETE DESIGN REVIEW OF NRX-AI COLD FLOW NONNUCLEAR ASSEMBLY (LRP) 8. COMPLETE REVIEW OF NA AI COLD FLOW ACEEPTANEE TEST PROC

9. COMPLETE REVIEW OF NRX-A] COLD FLOW NOW NUGLEARASSEMBLIY AGGEPTANGE TEST DATA (LRP)

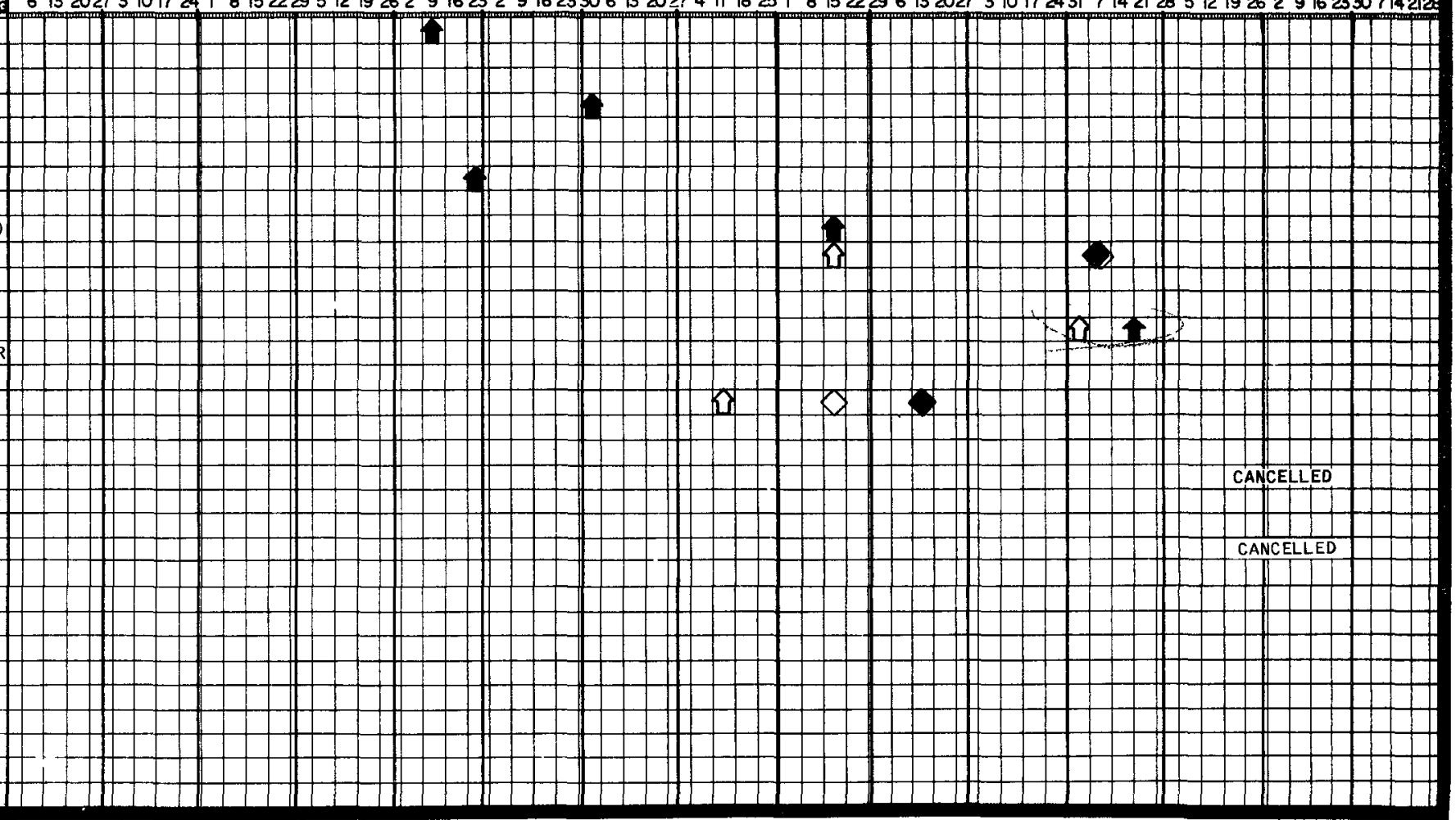

仓 SCHEDULED MILESTONE $\diamond$ RESCHEDULED MILESTONE Rescheduled to $\mathrm{cr} 64$ - Milestone aCHIEVEMENT $\checkmark$ RESCHEDULED MILESTONE ACHIEVEMENT 


\section{S/T 2.7 SAFETY}

ACCOMPLISHMENTS

$W / s$

REFERENCE

PLANNED

ACTUAL

EVIDENCE OF COMPLETION

\section{SITE OPERATION}

2-2.7 A I

(1) PROVIDE NRDS SAFETY PROCEDURES

COMPLETE

I. AGC REPORT NO.

AND REGULATIONS

FOR CY 63 2636-SS MATERIALS CONTROL MANUAL

2. NERVA OPERATIONAL SAFETY PROGRAMNOPPS I-A9

3.NRDS HEALTH AND SAFETY INSTR. MANUAL RN-HSM-OOOI 4. TRAINING DOCUMENTS 5 MEDICAL PROGRAM PLAN

(2) PROVIDE A SAFETY STAFF FOR NRDS

COMPLETE FOR CY 63
NRDS SAFETY STAFF ORGANIZATION OF 7-PROF. PERSONNEL - 3 WANL, 4 AGC 


\section{S/T 2.7 SAFETY}

\section{ACCOMPLISHMENTS}

$W / S$
REFERENCE

$2-2.7 \mathrm{~A}$
PLANNED

(3) REVIEW AND EVALUATE NRDS TEST AND OPERATIONS PROCEDURES

(4) COMPLIANCE WITH GOVERNMENTAL REGULATORY AND CONTRACTUAL

REQUIREMENTS AT NRDS
ACTUAL

COMPLETE FOR CY 63

COMPLETE FOR CY 63
EVIDENCE OF COMPLETION

SEE BIBLIOGRAPHY MATERIAL CONTROL NERVA OPERATIONAL SAFETY PROGRAM NOPPS I-A9

COMPLETE FOR CY 63 SAFETY PANEL

(2) ASSURE SAFETY IN DESIGN, MANUFACTURE, HAN- COMPLETE DLING, SHIPPING AND ASSEMBLY OF COMPONENTS
PARTICIPATION IN ALL 3 RFSP MEET'GS. AGC RPT. NO.2636-SS MAT'LS. CONTROL/RPT. NO.765:610-SS MAT'LS. ACCOUNTABILITY PROC'S. MANUAL 


\section{S/T 2.7 SAFETY}

\section{ACCOMPLISHMENTS}

$W / s$

REFERENCE

PLANNED

\begin{tabular}{ll} 
EVIDENCE OF \\
ACTUAL \\
\hline
\end{tabular}

2-2.7 B (CONT) (3) INCORPORATION OF SAFETY FEATURES IN NERVA ENGINE TESTS

COMPLETE

FOR $\mathrm{CY} 63$

AGC REPORT NO.2316OPERATIONAL SAFETY

EVALUATION OF ETS-I

(4) REVIEW OF ENGINE DESIGN FROM STANDPOINT COMPLETE

AGC REPORT NO.2316 OF (2) AND (3) ABOVE FOR CY 63 OPERATIONAL SAFETY EVALUATION OF ETS-I

(5) ASSIST AND PROVIDE DATA TO TEST AND COMPLETE PARTICIPATION IN RFSP LAUNCH SITE OPERATIONS AND RIFT CONTRACTOR FOR CY 63 MEETINGS - AGC REPORT NO. 242I - INITIAL AND REVISED 


\section{S/T 2.7 SAFETY}

\section{ACCOMPLISHMENTS}

$W / s$

REFERENCE

2-2.7 B(CONT)
PLANNED

(6) PROVIDE DESIGN REQUIREMENTS FOR AND REVIEW OF SAFETY AND DESTRUCT SYSTEMS AND COMPONENTS

(7) PREPARE AND REVIEW ALL REQUIRED HAZARDS AND SAFETY EVALUATION AND REPORTS

(8) PROVIDE REQUIRED INCIDENT REPORTS, EVALUATIONS, REVIEWS AND CORRECTIVE ACTION
ACTUAL

COMPLETE FOR CY 63

COMPLETE FOR CY 63

COMPLETE FOR CY 63

(9) PROVIDE DATA FOR AND DESIGN REVIEW OF FACILITIES AND EQUIPMENT

COMPLETE

FOR CY 63
EVIDENCE OF COMPLETION

AGC REPORT 2421NOV. 62 -AGC REPORT 2421 (REVISION) AUG 63

NARF GTR FIRE INCIDENT-FZK-164 DTD 14 JUNE 1963 
Purpose and Objective

To assure the maximum protection to operations personnel and the general public in the design, fabrication, and testing of the NERVA engine and its components, and to provide maximum protection to facilities and equipment consistent with the foregoing and with program objectives.

During the 1963 Contract Year, Subtask 2.7 encompassed the entire field of safety including operational, design and flight safety problems. By its very nature such a program is, generally speaking, not productive of hardware and technical report documents, but rather consists of review and approval or modification of designs and procedures, and recognition and correction of operational hazards to assure the minimization of danger to personnel and damage to property. The Safety Program consists of three phases: (1) operational safety related to the entire NERVA Program including the safety aspects associated with engineering, manufacturing, assembly and test operations at the various plants; (2) the design safety of facilities and the engine with its related handing and service equipment; and (3) the safety of projected flight operations.

In all of these areas, the Aerojet accomplishment has been significant. We have complied with all of the objectives set forth in the contractual work statement and, with one exception, have met the milestones set forth in out program within the reasonable limits of possible accomplishment. For purpose of this discussion, the work statement as set forth in the 1963 Revised Program Plan RN 63002 will be reviewed and accomplishment and significant progress under each item will be briefly discussed.

Under Item (A) of the Work Statement for Subtask 2.7, Site Operation, four objecties are set forth.

$2-2.7-A(1)$

All essential site operation procedures required during Contract Year 63 were prepared. The preparation of detailed procedures related to safety aspects of assembly and operation of specific reactors, and the conduct of specific tests was initiated. However, the delay in the reactor test schedule precluded the completion of detailed procedures. The work statement was geared to the

$$
2 \cdot 7-1
$$


provision of safety procedures in accordance with the overall program status, and in this context our program is current and contracted work is completed.

Basic safety policies, instructions and procedures related to the control of nuclear materials, the operational safety program, necessary medical arrangements and safety training were prepared and are listed in the bibliography .

$\underline{2-2.7-A(2)}$

A safety staff of seven people ( 4 AGC - 3 WANL) has been organized for the Nevada test station operation and is currently functioning as called for in the work statement.

$\underline{2-2.7-A(3)}$

All test operations procedures have been reviewed, evaluated and modified as necessary to comply with sound safety practice and contractual requirements. These reviews were documented in the form of internal memoranda to the originating organizations. Examples of this documentation are listed in the bibliography.

$2-2 \cdot 7-A(4)$

Designs of facilities and subsystems were reviewed for compliance with regulations and functiunal safety requirenents through consultation with SNPONevada and SNPO-Cleveland. Preliminary arrangements have been worked out to provide for appropriate supervision, review, and control by these organizations. Arrangements have been made for the utilization of the services of SNPO-Nevada and the Support Services Contractor, and procedureal manuals for the control and management of source and special nuclear materials have been prepared. An overall program for the continued assurance of compliance with all regulatory and contractual requirements has been prepared. A listing of the principle documents applicable to this activity is set forth in the bibliography.

Under Item (B) of the Work Statement for Subtask 2.7, Design Safety, nine objectives are set forth.

$\underline{2-2.7-B(1)}$

Formal membership on the Rover Flight Safety Panel has been maintained and in addition, the resources of various related activities, particularly to 
the design of destruct systems and countermeasures, have been provided to the Rover Flight Safety Panel during Contract Year 1963. Formal presentations were made by AGC at three of the scheduled meetings during this contract period. $2-2 \cdot 7-B(2)$

Under this activity, the proposed procecures for shipment and handing of fuels and core materials and design of handing facilities have been reviewed and the necessary corrective actions taken to ensure the safety of these operations. Fuel storage facilities and special equipment for handling radioactive components and materials were evaluated. Safety criteria pertaining to siting and to radioactive materials handling requirements for the NRDS Radioactive Materials Handing, Decontamination, and Storage Complex were developed. The operational support plan for NRX-A2 was reviewed. The review of the assembly, shipping and criticality testing of the $\mathrm{NRX}$ reactor was initiated. Some of the intermal documents resulting from these activities are listed in the bibliography. $\underline{2-2.7-B(3)}$

In CY 1963 this activity consisted primarily of the review of ETS-I operational requirements and the preliminary procedures for its operation. Detailed procedures for engine test operations at NRDS were not available for review during this contract period. Internal documentation which resulted from this effort is contained in the bibliography. $\underline{2-2.7-B(4)}$

The details of the NERVA engine design have not progress to the point where a rigorous examination of engine components from the standpoint of safety would be possible. The engine specifications have been examined from the standpoint of safety in normal and abnormal operation, particularly as related to the engine tests in the ETS-I Complex. Pertinent documentation is included in the bibliography.

$2-2.7-B(5)$

A significant portion of the effort required under this element of the work program grows out of the Source Term Program and the data which will be produced thereunder. The major portion of this activity is conducted under the 
Westinghouse subcontract. Arrangements were made during CY 1963 to provide available data derived from this activity directly to the participating agency in the NERVA Program, including the Rover Flight Safety Panel and the RIFT Contractor. Detailed descriptions of the NERVA engine system and pertinent data for use in safety analysis and planning were presented to the Rover Flight Safety Panel and documented in the Rift Safety Review Program reports, AGC Report No. 2421 and AGC Report No. 2421 (Revised). $\underline{2-2.7-B(6)}$

Preliminary and general design requirements for safety, destruct, and countermeasure systems have been generated throughout the contract year as guidance for the development activities in reactor destruct systems and anticriticality poison mechanisms. Detailed design information and data on the NERVA engine and the RIFT stage were supplied to Westinghouse in March (772:H\&S: 055-Conf) to enable the conceptual design of the in-flight poison system to proceed. The design of destruct components has not progressed to the point where a review from the standpoint of reliability and performance would be meaningful. It was planned during Contract Year 1963 to provide a report on the design requirements for safety and destruct systems for the NERVA engine. This planned activity was not cumpleted and has been deferred to CY 1964.

$\underline{2-2 \cdot 7-B(7)}$

Preliminary due to the slippage in the NRX-A reactor test schedule, the preparation and review of the INRX-A Safety Analysis Report was delayed to CY 1964. A significant effort was involved in the coordination and establishment of the content and format for the NRX-A Safety Analysis Report and supporting documentation. Partial redirection by SNPO-C of the effort initiated early in the contract year (reference: SNPO-C letter NNO:DS of 15 May and 10 July 1963) caused additional coordination effort on this task that was not anticipated and resulted in further delays in the preparation of the draft material for the $N R X-A$ Safety Analysis Report.

The shipping container design and the preliminary draft of the Shipping Safety Analysis Report was reviewed with Westinghouse in December 1962. As a result of this review, major design changes were incorporated into the shipping

$$
2.7^{-4}
$$


container design and major revision to the Shipping Safety Analysis Report was initiated. The Assembly and Shipping Safety Analysis Reports were completed by Westinghouse by the close of the contract year and are currently under review by REON.

The NRX-A Disassembly Operations Safety Analysis Report was delayed by slippage in the reactor schedule as noted above and will not be available until CY 1964. REON review of this report will be performed as draft material becomes available.

The critical facility safety analysis report covering activities at WANEF was completed by Westinghouse at the end of the contract year and is currently under review by REON.

$\underline{2-2 \cdot 7-B(8)}$

Fortunately, there was a minimum of accident and incident situations requiring report and corrective action during CY 1963. However, our investigation committee prepared a report on the 1962 LRP fire. A major review was undertaken relating to the fire and damage at the NARF-GTR and incident reporting requirements for the developmen of the propellant feed system were evaluated. Pertinent documentation to this effort is contained in the bibliogrphy.

$\underline{2-2 \cdot 7-B(9)}$

A major part of the effort of the safety staff was properly devoted to this activity during the contract year and over forty safety evaluation and review reports were prepared in support of the facility design and review of the functional safety of facilities and equipment operation. These reviews covered all aspects of the facility and operational design with principal concern directed at the adequacy of shielding and nuclear materials handling problems. Shielding requirements were established for equipment and facilities. Decontamination requirements in support of the exhaust duct design were provided and data were developed with respect to expected levels of fission-product plateout contamination. Radiation monitoring instrumentation systems for E-MAD and ETS-I facilities were reviewed and appropriate modifications accomplished. Design data were provided for the location and design of the radioactive materials storage and disposal areas. 
Although considerable work remains to be done in the review of operational and handling procedures as a result of facility and support equipment reviews during CY 63, there is real assurance that the facilities and equipment as now existing or designed can be safely operated. Documents prepared in support of this activity are listed in the bibliography. 
SUBTASK 2.7 - BIBLIOGRAPHY

Work Statemert

Rofesence

Documenic Description

$2-2.7 A(1)$

$2=2.7 A(3)$

"Coments aut Revisions to Lead Safety Engirooring Tasks for Prelimirary Count Schodulo, 772aKkS:006, 27 Octobar 2962

"Safoty Procedures During NRx $\rightarrow$ A Pnal Asembly and Checkouti" 770:0297, 28 Jamary 1963

"Roview of Test Stand and Facilitics Preparation and Countdown schedulos" 772:1385:031, 6 Fobruary 3963

"NRDS - SOP RevLew" 772:S:001, 3 April 1963

"Caments on Prelininary Draft of NDDS Standard Operating Procedures $_{9}$ ' 772:S:006 8 Apri2 1963

"Comments on Preliminary Draft of MRDS Standard Operating Procedure," $772: 10_{4} 8_{2} 3$ Juns 1963

"Review of NTO 898, Procedure for Recelpt and Inspootion of Reactor at $\mathrm{NMO}_{2}$ "720:1004h, 19 September 1963

"Roview of MRX-12 Tost Plan" - Rough Draft, 778:M009 25 September 1.963

"Roviou of IRX oA Operational Support Plan - Revision $1_{9}$ " 778 85012, 26 Septernoer 2963 
Work Statement

"Safoty Alarn and Warning Systens for NRDS," $772: 0216,26$ October 1962

"Exiso Facility Thase II Preliminary Design," 770:0237, 9 Novomber 1962

"Trip Report i SNPOAN Safety Prograra for NRDS," 772:His: 013, 7 December 1962

"Minutes of Technical Meecing on Radioactive Materials Facilities Dagign Criteria $(3.8)_{8}$ " $17417: 0155,23$ April 1963

"Minutes of Teqhnicol Meeting on Radionctive Materials Facilities Design Criteria (3.8) 2 and 3 May 1963," 1741:01.94, 21 May 2963

"Roview of SS Matertals Conirol Instruction Manuel for RIERVA Progran, Report No. 2636" 772 :M1064, 18 JuIy 2963

"SS Materiala Control Instruction lanual for NERVA Program" AGC Roport No. 2636, July 1963

"Safeity Requirenentis for EANAD Radiation Monitoring," 772 :MO68, 24 July 1963

"NERVA Operational Safecy Programg" NOPPS I-A9, 22 hugust 19",

$2 \backsim 2.7 B(2)$

"Draft Safoiy Report for Shipping NERVA Reactors, WANL $=1$ TIE-202, 770:0281, 3 January 1963

"NRX Core Vault Spsco at RMMD, 772 :Hes:056, 12 Marcin 1963

"E-HAD Phase I Final Drawings \& Spocifications Reviews" $772: 3019,18$ April 2963

"Radioactive Shipmenis to REON from General Dynarios, Fit Worths " $772: 11023,25$ Apre1 2963

"Task 2.8 - Radioactive Materials Complex," 772:M028, 7 May 1963

whanL Procurament Packages $590 \mathrm{Cr}-34778$ and $590 \mathrm{CN} \times 37 \mathrm{OU}_{4}{ }^{\circ}$ $770: 0362_{2} 14 \mathrm{May} 1963$

"Source Strengths and Scattered Radiation Irom Spent Fuel Storago:" 774: $\mathrm{NA}: 046_{3} 27$ Nay 1963

"Generation of Decay Heat After Shutdown," 774:HA:055, 13 June 2963 
Work Statoment

Bororenco

$2+2.7 B(2)$

$22.7 B(3)$

$2-2.7 B(4)$

$22.7 B(5)$
Docuneni Description

"Evaluation of Gamin Ray Dose Ratas in Air from Spent NRX Reactors" 774:17A:070, 18 suly 1963

"SS Materials Control Instruction Manual for NRDS" AGC Report No. 2636, July 1963

"Preliminary SS Materials Accountability Procodures Manuel for Azusa SS Station $\mathrm{CLC}_{2} " 765: 610_{2}, 30$ August 1963

"Safety Revien of WANEP,"778.5003, 23 September 1963

"MRX 0 A2 Opsrational Support Plan sovision $I_{2}$ " 778:11011, 26 Soptember 1963

"Reviev of Dram Safety Report for Shipping NBRVA

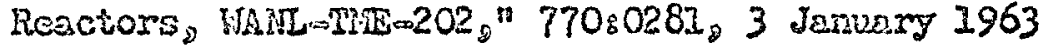

"Oparational Safoty Evoluation of ETS-I Complex," AGC Report No. 2316, October 1.962

"Coments and Rovisions to Leed Safoty Bnginooring Tasics for Preliminary Count Stheoule "772:Hik:006, 27 Cotobor $196 ?$

"Abromal Engine or Irrediated Fuel Handling Situations at ERS-1, 772:13:5:029, 4 February 1963

"Revien of Tegt Stand and Fecilitios Proparation and Counidom Schocinle,772:His:031, Enclosure (1)。 6 February 1963

"Fis.eld Survay at ETSol for Losating Sarety System Iach" $772: 2505 \mathrm{~d}_{9} 10$ June 3963

"Operational Safety Eveluation or ETS-I Complex" AGC Report No. 2326, October 1962

"Comments on WhL kicdes of Failure Analysis: NRX-A Huclesr Subsystomg" 772:HO16, 16 April 1963

"Roview of N10 898 Procedure for Receipt and Inspection of Reactor at $\mathrm{KTO}_{2}$ " 720:1004h, 19 Septomber 1963

"RIFT Safety Program" 760:1833, 25 Octobor 1962

"Sibcontract NP-1 a MEEVA Sygtems Descriptions for tho RIFT Safety Reviet Prograng" 760:3496, $23 \mathrm{May} 1963$

"Presentation to the Rover Flight Safety Panel lleating at Cape Canaveral, I - 3 May 1963,"772:14040, $16 \mathrm{May} 1963$

$$
2.7-3 a
$$


Woris Statement

Rererence

$2-2.7 B(5)$ (Continued)

$2-2 \cdot \operatorname{TB}(6)$

$2-2 \cdot 78(7)$

\section{Docunent Description}

"RIFI Safety Review Prograsn - HERVA Systems Description," AGC Repori 2421, November 1962 \& Revislon August 1963

"In-FIight Poison Systern," 772:H\&S:055, 12 March 1963

"RTIT" Saloty Review Program - NERVA systems Description," ACC Roport 2421, November 1962 \& Revision August 19.63

"MRX-A Hazards Report," Project Directive Ho. 167 , 14 February 1963

"INRX-A Safeguards Report IiRP Contributions," Project Directive 167A, 3 April 1963

"Tech Discussions with IASE Personnel," 772:MO29, 7 May 1963

"Dept 780 Contributions for IRR-A SaPeguards Report," 10 May 1963, T72:11033

"Review of SEPO-C Requirements for SARs," TT2:LO42, 20 Bay 1963

"Review Dept 780 Safety Report Contributions," 7TI:RS: 025,29 May 1963

"INRX Safety Analjsis Reports" 772:I050, 4 June 1963

"IRRX Safety Anolysis Report," 772:I049, 6 June 1963

"INRX Safety Analysis Report," 770:2088, 9 July 1963

"IRX Safety Analysis Report," 777:L082, 30 Aueust 1963

"WRX Safety Analysis Repori," 778:L006, 17 September 196

"Criticalfty Safery Analysis of Reactor Fuel Storage at WANL, T78:MO10, 26 September 1963

"Sapety Review of WANHE," 778:M008, 23 September 1963

$$
2.7-4 a
$$


Work Statement

Relerence

$2-2 \cdot 7 B(8)$

$2-2.7 B(9)$
Document Description

"Preliminary Report of IIre Inveatigation Commitee IRP," 770:0304, 6 February 1963

"Fire Incident and Damage Report of 30 March 1963 at ITAET GIR Radiation TPPects Testing Systom," IZK-164 14 June 1963

"Incident Roporting Requircments in Connection $\mathrm{w} / \mathrm{s} / \mathrm{p}$ $1.2 .3, " 720: 155000,20$ August 1963

"E-IIAD Postmortem Cell Pece," 772:H8S:003, 22 October 1962

"Safoty Alarm and Warning Systems for IIRDS," 772:0216, 26 October 1962

"Prelininary Review of D-imD Phase II Preliminary Design," 770:0237, 9 Novernber 1962

"Decontamination of IITis BNIB Mozzle at IRDS," TT2:Fis:010, 19 November 1962

"IIIS-I Exhaust Duct Neutron Activation and Iission Prod. Plateout Dose Rates," 7TI:RI:028, 7 Decomber 1962

"Radiation Analysis for Hoclear Erhaust System," 77I:RI: 051,24 Fanuary 1963

"Review Coments on TURCO Decontamination," $772:$ HR:S: 030, 5 February 1963

"Tission Product Plateout Experiments for Ituclear Fxhaust Systems, T72:HRS:035, 15 February 1963

"riwi B-4A ITozzle Decontamination Experiment," 772:EkS: 044,21 Tebruary 1963

"Reviev of IHIRVA Malfunction Arolysis OPS," 772:178:S:053, 8 Marcin 1963

"Review of AEnRON Report 2408A, Preliminary Design for Additions to IFIS I," I74I:0109, 11 March 1963

"Tasik 3.8 - Radioactive Materials Complex," 772:Ers: 054, Misch 1963

"IRDS E-MAD Facility Phase II - Drawing Review, T72:HES: 059, 15 Morch 1963

$$
2.7-5 a
$$


Tork Statement

Reference

Documont Description

2-2TB(9) (Continued) "Review of Radsation Intensity Relative to MCC in

E-MAD, TT1:RI:097, 21 March 1963

"Equipment Specification for 60-ft Crane," 772 :

HeS:060, 21 llarch 1963

"EIS-I I\&C Design Data Review," T72:H\&S:061, 22 March 1963

"Bid Specification for Cemma Probing of MCC," T72:HRS: 2 April 1963

"Eunctional Specifications for HIS-1 Safety System," IT $41: \mathrm{OI}_{10}$, 15 April 1963

"Sefety Revier of RCC Radiation Shielajing Windows," 772:012, 15 April 1963

"Safety Review of MCC Shielded Cab and Assessories," 772:013, 15 Apri1 1963

"E-MAD Phase I Final Dwgs and Specification Review" T72:14019, 18 Apri1 2963

"E-MAD Phase II Drawings 1425 A-202 and 1425-A-301," T72:MO27, 30 April 1963

"Comments on Task 3.8 - Radioactive Miaterials Lamplex," $772: 15028,7 \mathrm{Kay} 1963$

"Er-MAD Phase II Design Reviem," T72:M032, 9 May 1963

"E-BAD Phese "wid Safety Review," 741:0186, 13 May 1963

"Review of IF BAD Phase I Muclear Sotelding Feport," $772:$ M037, 14 Hey 1963

"Tech Discussions w/EC\&G on IIIS-I Sarety I\&C," 7T2:MO44, 21. May 1963

"TrMAD Facility - Phase I and II Radiation Monitoring System," 772:Mo 45, 28 Mey 1963

"Tire Protection ana General H\&S Equipment for EMAD Facility Actiyation," T72:NO52, 5 June 1963

"E-MAD Radiation Monitoring System, Phase I \& II," I740:0057, 17 June 1963

$$
2.7-6 a
$$


Work Statenent Rezeronce

"FIS-I Specifications Reviev," T72:M5055, 20 June 1963

"EnS-1 I3:C Safety Design System Data Review," 772:M058, 1 July 1963

"Safety Requirements for E-MAD Kediation Monitoring," $772:$ MO68, 2lt awy 1963

"Egr: vaent Fequirenents for FomD Counting Room," $772: 1069,25$ Juity 2963

"T.WWES Rectetion Monitoring System," 740:0061, 16 Augrest 1963

"Mcc Ridetien lwvels vs Distance from Flat Car Mounted Disoswembles, ;es," 77t:092, 20 August 1963

"Safety Review or FmifAD Plase II Designs," 772:M080, 20 Ausust 1963

"Evaluation lof linurec Control Car Shield Design," T74:055, 22 Augretc 1963

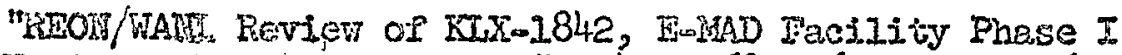
Wuclens Shiepting Report," 74j:0268, 26 August 1963

"Rexid of kfety Provisions of MW Kelloge Conceptua? Design Fackige ror MARI", 778:M001, 5 September 1963

"RGOI Compos.. a Reviow of B-IHAD Phase II Designs," 778 s 7 na, 5 septicibe: 1963

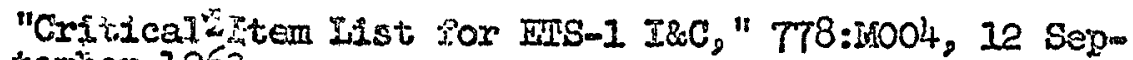
tember 1963 


\section{(Q) NERVA}

SCHEDULES AND MILESTONES

CONTRACT YEAR 1963

TASK ITEM 2.7

局

SAFETY

1962

1963

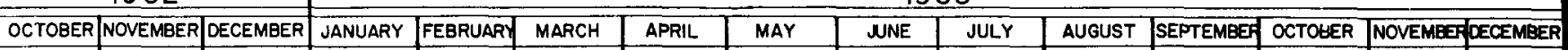
$61320273101724|8152229512192629162329162330613202741| 1825 \mid 8152229613202731017243171421285121926291623307142128$

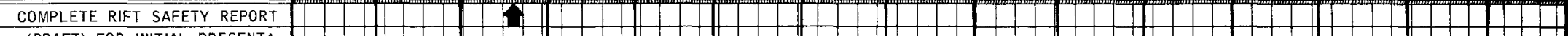
(DRAFT) FOR INITIAL PRESENTATION AND REVIEW

ISSUE REVISED RIFT SAFETY REPORT ON NERVA ENGINE DESCRIPTION

ISSUE PRELIMINARY NRX-A SAFEGUARDS REPORT ISSUE INITIAL SOURCE TERM DESCRIPTION

ISSUE HEALTH \& SAFETY PROCEDURES MANUAL FOR NRDS OPERATIONS

ESTABLISH S/S MATERIALS

STATION AT NRDS FOR RECEIPT FOR NRX-A-ICF REACTOR

COMPLETE EMERGENCY PLAN FOR NRX-A TESTS AT NRDS

ESTABLISH SYSTEMS OF INSPECTION FOR THE REVIEW AND EVALUATION OF ALL NUCLEAR HAZARDS ASSOC. WITH NERVA TEST OPERATIONS

FLIGHT OPERATIONAL SAFETY SYSTEMS REQUIREMENTS REPOR . ISSUE INITIAL REPORT OF HAZARDS EVALUATION

11. PROOF TEST SAFEGUARDS REPOR ISSUED

12. REACTOR ASSEMBLY SAFETY ANALYSIS REPORT COMPLETE

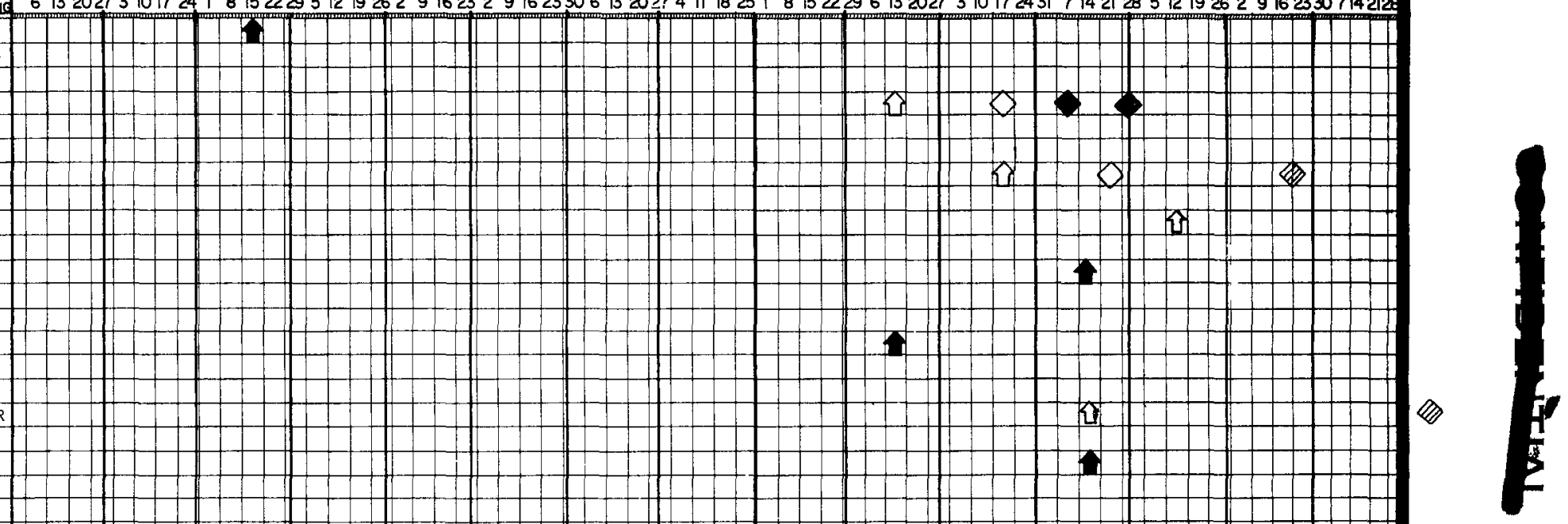

- MILestone achievement 


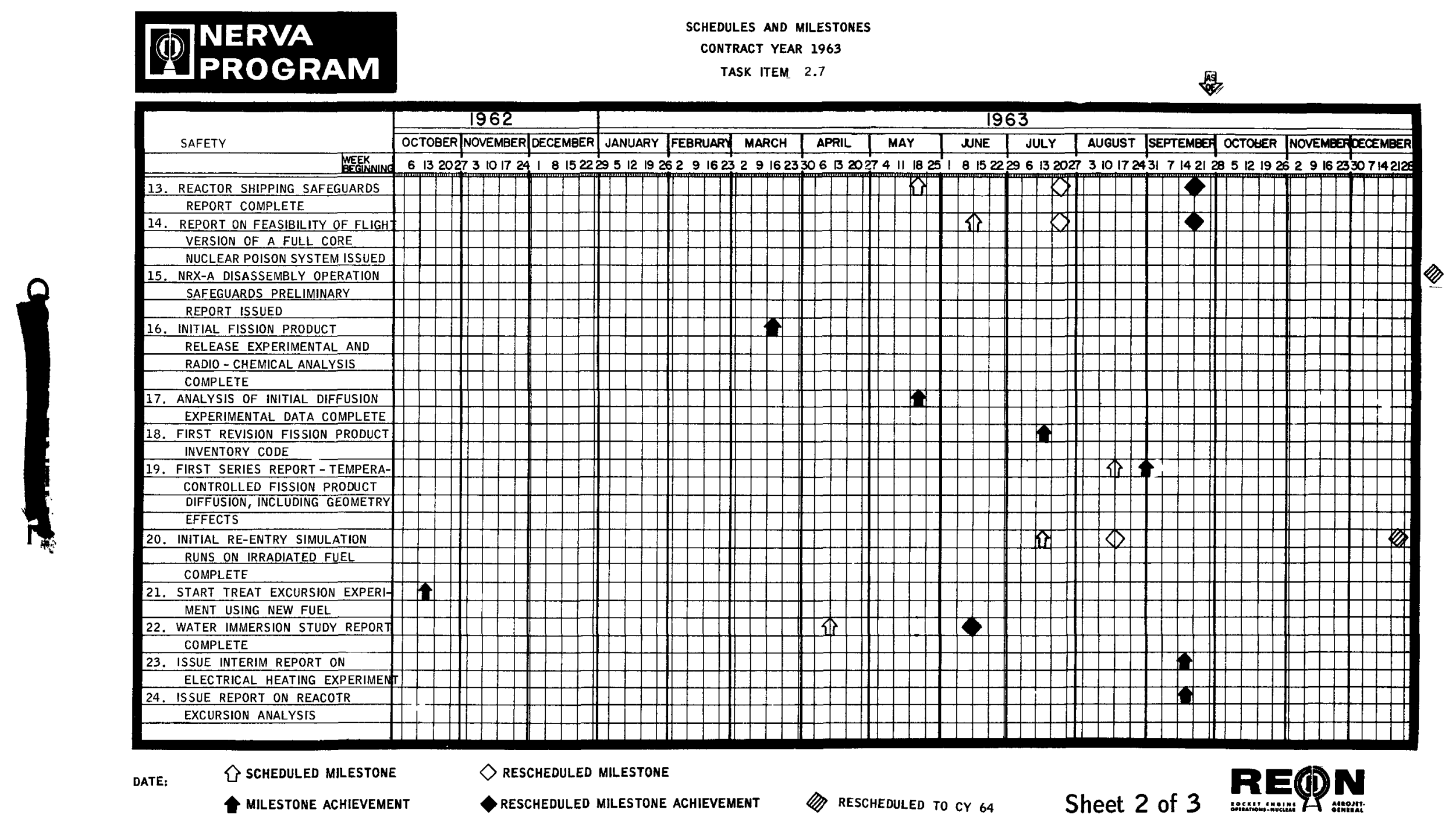




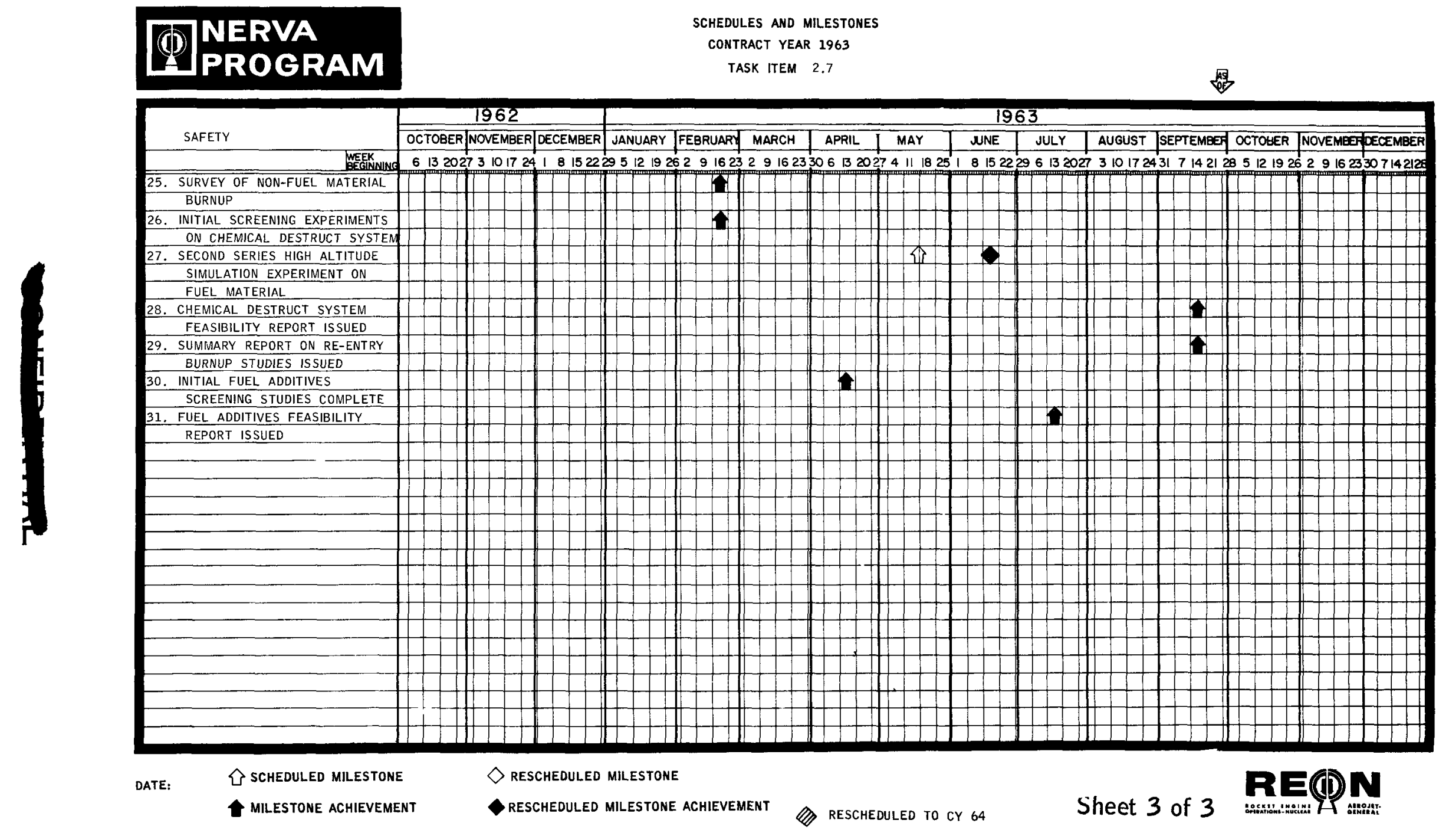


Purpose and Objective

The objective of this subtask was to initiate specialized indoctrination and familiarization to wualify appropriate personnel for assignmeni anc performance of operations in support of the NERVA program.

Accomplishments

Staffing was maintained at four engineers throughout CY 1963 for implementing the training effort at NRDS and providing direction, review and integration of all NERVA training activity within participating Aerojet Divisions and with subcontractors. During the contract year, the following itemis were accomplished.

1. Assisted WANL in the preparation of operator job descriptions for the Test Cell "A" Control Point and of certain other positions at E-MAD based on R-MAD operational experience. Assistance was also provided in performing job task analysis and the subsequent establishment of a preliminary detailed operators' Qualification Program.

2. Prepared psychomotor testing procedures entitled "Psychomotor Study" to aid in the selection of "remote handling" operators at E-MAD. This procedure is also applicable for selecting new hires at R-MAD or at any facility utilizing remote handlins equipment.

3. Completed a "Selector and Screening Studj Manual" for the purpose of determining the screening process required in selecting operators for "remote handling" equipment at E-MAD or any other facility, such as R-MAD or ETS-I, which does or will utilize remote handling techniques.

4. During the final quarter of CY 1963, a government-furnished training trailer was established supplied with standard sudio-visual equipment, for conducting lectures and office space for the training staff members. In addition, the preparation of visual training aids was initiated to permit effective dissemination of course presentations. 
5. Prepared a "Test CeII 'A' Indoctrination" manual which was used during the final quarter of CY 1963 for three groups of trainees totaling 28 enrollees. The course is of $\delta$ days duration, or 48 hours, and covers the various process systems including radiological safety. The large majority of trainees who completed this course were assigned to Test Cell "A" operations.

6. Initiated preliminary assembly of training materials for courses in nuclear physics, cryogenics, and general NRDS indoctrination of new employees, which will continue into CY 1964.

7. Prepared a preliminary list of recommended training mockups of engine hardware for future NERVA training programs.

8. Established a NERVA Training Plan accepted by SNPO-C for CY 1964 and also reviewed and recommended revisions to the preliminary training program submitted by Aermican Machine and Foundry for E-MAD Operations in CY 1964 . 


\section{SUBTASK 2.8 - BIBLIOGRAPFY}

\section{Psychomotor Tests}

Visual gcreening and Praining Study

l'est Cell "A" Indoctrination Course Syllabus

Test Cell "A" Indoctrination Course

NRDS Indoctination - Assembly of Handouts for Slide Ixcture Presentation. 


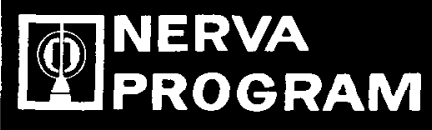

SCHEDULES AND MILESTONES

CONTRACT YEAR 1963

TASK ITEM 2.8

㔠

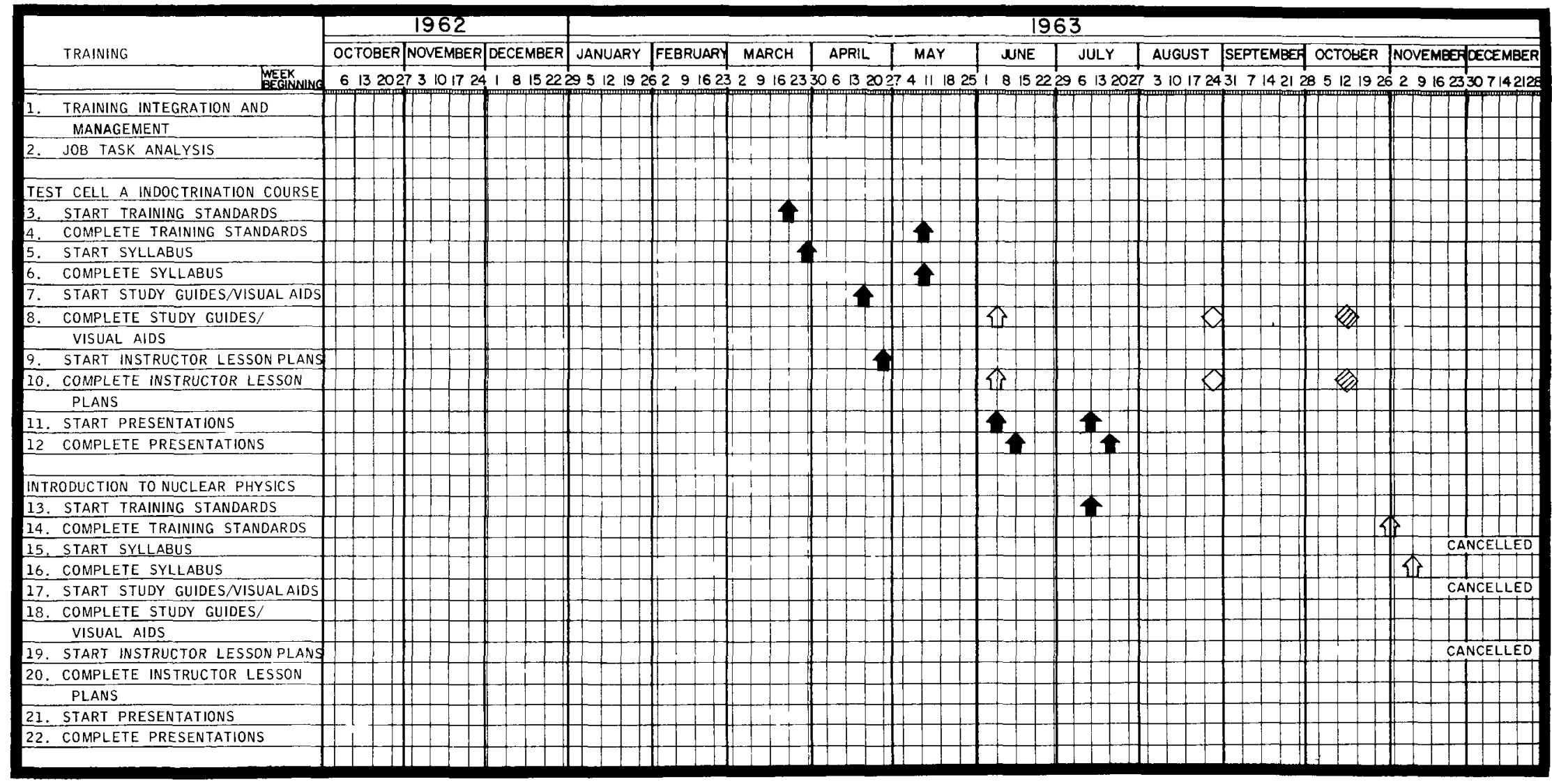

DATE:

$\checkmark$ SCHEDULED MILESTONE

- MILESTONE ACHIEVEMENT $\diamond$ RESCHEDULED MILESTONE

RESCHEDULED MILESTONE ACHIEVEMENT
- Rescheduled to cy 64
Sheet 1 of 2 RE(P) $\mathbf{N}$ 


\section{NERVA
PROGRAM}

SCHEDULES AND MILESTONES

CONTRACT YEAR 1963

TASK ITEM 2.8

成

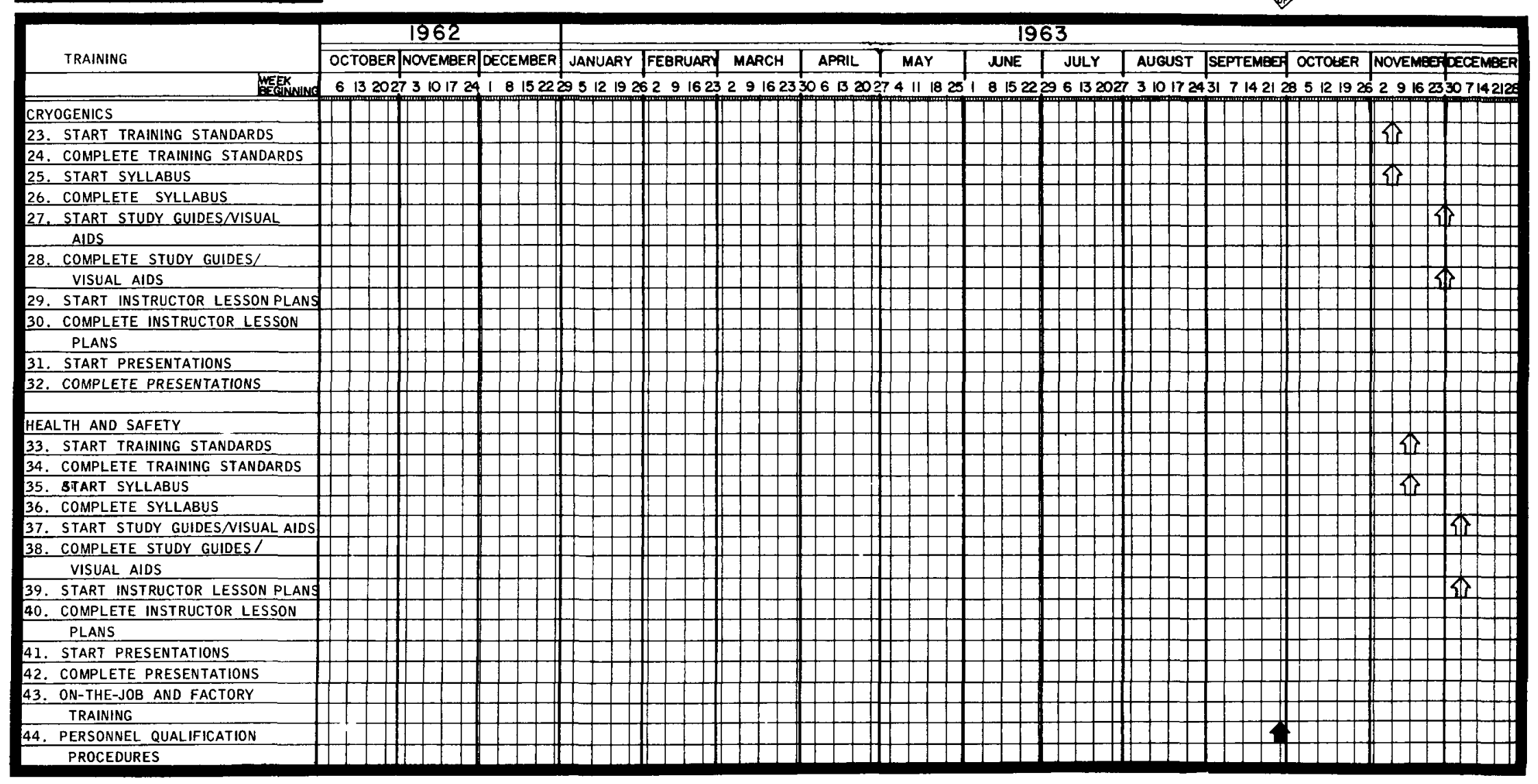

DATE:

$\checkmark \mathrm{SCHEDULED} \mathrm{MILESTONE}$

$\diamond$ RESCHEDULED MILESTONE

- MILESTONE ACHIEVEMENT

REScheduled milestone achievement

Rescheduled to cy 64

Sheet 2 of 2

$\mathbf{R E}(\mathbf{P}) \mathbf{N}$ 
Purpose and Objective

The objective of this tank was to provide LASL with technical assistance at Los Alamos and NRDS in areas related to rocket propulsion. Accomplishment

The level of engineering personnel assignment was that which was mutually agreeable to both REON and SNPO-C. During the first quarter of CY 1963, four AGC engineers were assigned to LASL at NRDS and three engineers at Los Alamos. Personnel at NRDS participated in KIWI reactor and test car assembly, disassembly and hot cell operations while those at Los Alamos participated in reactor analysis reports, instrumentation, data evaluation and control system and component design analysis.

During the third quarter of CY 1963, LASL support at NRDS was phased out so that during the final quarter of CY 1963 support was only provided at Los Alamos and consisted of three engineers. The four engineers at NRDS were integrated into the NRX organization. 


\section{S/T 3.0 GENERAL SUPPORT FACILITIES}

\section{ACCOMPLISHMENTS}

$W / S$ REFERENCE 2-3.0-(1) SUPPORT TO SNPO-C

(b) PROVIDE AS REQ'D UPDATED REQUIREMENTS

2-3.0-(2) DOCUMENT REVIEW

(d) PERFORM REVIEWS PER SNPO-C REQUESTS

(d) PREPARE AND ISSUE PRD DURING CONTRACT YEAR REQMTS. DOCUMENT

SPECIAL REQUEST SNPO -W

(d) CONDUCT AND REPORT MISC. TECH STUDIES AS REQUESTED

ASSIST IN EVALUATION OF
COMPLETED. AIRSTRIP ANALYSIS AUX TEST STAND STUDY AND NRDS TEL. REQMTS. TAB

PERFORMED

(d) REVIEWED PRELIM. DRAWINGS \& REPORTS

(b) REVIEW PRH

(d) SUBMITTED FIRST ISSUE

(b) SUBMITTED FIRST QUARTERLY REVISION COMPLETED EXISTING NTO FACILITIES FOR USE IN NUCLEAR ROCKET PROGRAMS
EVIDENCE OF COMPLETION

LTR. 720:571 DTD $11 / 8 / 62$

AGC. REPORT \# 2433

DTD $12 / 28 / 62$

LTR 741:0065 DTD 1/8/63

AGC TWX DTD 10/17/62

LTR 780:0110 DTD 5/21/63

AGC REPORT \# 2578

DTD 6/25/63

AGC REPORT \#2578 REV. 1 DTD $10 / 1 / 63$

GOVERNMENT

TRIP REPORT

\section{REON-ROGKET ENGINE OPERATIOIS-NUBLEAR}


Purpose and Objectives

The objective of the Task 3 Series (less S/T 3) are in general to provide technical assistance to SNPO-C as required in establishing NRDS Facility requirements and facility criteria, perform design reviews of the AE designs, monitor as requested the procurement and installation/construction, review and/or supply activation plans and advise or assist SNPO-C in the facility acceptance of the facility item from the contractor.

It is to be noted that all of these $S / T$ were negotiated at a level of effort basis and that the performance of the required work was dependent on the basic REON Facilities group being assigned on various $S / T$ 's as the work load demanded with some peak loads being handled by AETRON in certain areas. Conclusion

In conclusion, all milestones, reviews, work requests, criteria, studies have been completed in a timely manner which aided SNPO-C to continue creation of the NRDS facilities for the NRX and Engine development programs. 
Purpose and Objective

1. Support to SNPO-C

a. Conduct and Report on Miscellaneous Technical Studies

(1) REON reviewed the Lockheed Aircraft Corporation

"Survey of Proposed Airport at Jackass Flats, Nevada." A comparative analysis of the Lockheed plan versus a previously submitted (during CY 62) REON plan, was completed and submitted to SNPO-W in L720:571 on 8 November 1962. Conclusions reached was that an airfield was required at NRDS.

(2) A study of requirements and development of criteria for alternate methods of testing an E-Engine at NRDS was instigated per SNPO-C letter dated 11-20-62. Subtask 3.0 in conjunction with Subtask 3.2 completed and issued REON Report No. 2433 on 12-28-62.

(3) A tabulation of telephone stations and extensions was made of the Direct Iine and Dial Telephone Subsystems survey ETS-I Complex as requested by SNPO-C letter FDB: CEF dated I August 1962. Results of this tabulation were transmitted to SNPO-C (in REON L741:0065 1-8-63).

b. Update Requirements

(I) No requests were received to update requirements for general support facilities; however, updating was achieved via the PRD reporting.

2. Document Review

a. Perform reviews per SNPO-C requests:

(1) A review of 6 preliminary drawings of the NRDS Support Area Plan was made at the request of SNPO-N (letter 9 October). Comments on these drawings were sent to SNPO-C by TWX on 17 October 1962 (refer to Bibliography). Significant problems were identified and a meeting was requested to discuss these problems which has not yet been scheduled. 
(2) Comments resulting from a REON review of the NRDSSOP were compiled and transmitted to NRDS Operations Division for inclusion with their submittal at the request of NTO. (to SNPO-C - TWX 8 May 1963).

3. Program Requirement Document

a. Program Requirements Handbook (PRH)

(1) The Program Requirements Handbook - preliminary (PRH) issued by SNPO-N which provided the guidelines for the preparation of Program Requirements Documents (PRD) was reviewed and comments were submitted to SNPO-C (L780:0110) (Refer to Bibliography").

b. Program Requirements Document (PRD):

(I) The development and publication of a Program Requirements Document (PRD) was accomplished and the first issue of AGC Report No. 2578 was made in June 1963 (Refer to Bibliography). The first quarterly revision has been completed and is to be published during October 1963 .

4. Special Request SNPO-W

a. Evaluation Study: :

(1) As required by SNPO, REON assisted in the evaluation of existing NTO facilities for use in the Nuclear Rocket Program (L74l: M0564) (refer to Bibliography). This inspection tour involved evaluation of the PLUTO facilities at Area 401, NTS. The conclusion of recommendations of this meeting were to be documented in SNPO-W trip report.

Conclusion

All SNPO-C requests and direction were completed on a timely and satisfactory basis. 
SUBTASK 3.0 - BIBITOGRAPHY

\begin{tabular}{|c|c|c|c|}
\hline INSM & REFERENCE & SUBJECT & ORTGINATOR/ADRESSES \\
\hline 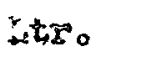 & $10-9-62$ & Preliminary Mester Plan for NRDS & Huff, SNPOSN to REON \\
\hline$T W X$ & $10-17062$ & Prelininary Mastor Plan for MRDS & House to Schroeder \\
\hline Ltso & $\begin{array}{l}720: 571: A C J: \\
g b=11=8=62\end{array}$ & Airstrip at Jackass Fats, Nevada & House to Finger \\
\hline Ltro & $11-27-6$ & NRDS Commanications & Schroeder to House \\
\hline Raport & $\begin{array}{l}\text { No. } 2433 \\
12=62\end{array}$ & $\begin{array}{l}\text { Auxiliary Static Test Facility } \\
\text { Study }\end{array}$ & \\
\hline Ltro & $1-8=63$ & NRDS Communications & Stinratt to Schroedes \\
\hline 2650 & $2-26-63$ & Program Requirements Handbook & Dickson, SNPO-NOREON \\
\hline$T W X$ & $5-10-63$ & Program Requirements Documeni & Ryland to Schroodar \\
\hline Ltro & $5-21-63$ & $\begin{array}{l}\text { Comments on Prog?am Requiremertos } \\
\text { Hardbooic }\end{array}$ & House to Schroedor \\
\hline Report & $\begin{array}{l}\text { No. } 2578 \\
6.63\end{array}$ & Program Requirements Document & \\
\hline Litro & $6=25-63$ & $\begin{array}{l}\text { Program Requirements Document } \\
\text { for NRDS }\end{array}$ & Ryland to Schroedar \\
\hline itro & $7-26-63$ & $\begin{array}{l}\text { Utilization of Pluto Facildties } \\
\text { in Nuclear Rocket Progxan }\end{array}$ & $\begin{array}{l}\text { HoBoJohnson/N.R.Slivka } \\
\text { to Finger" }\end{array}$ \\
\hline
\end{tabular}




\section{S/T 3.I NERVA EXHAUST SYSTEM}

ACCOMPLISHMENTS

$W / s$

REFERENCE

A. ENGINEERING

$2-3.1(1)$

EVALUATE SUBSCALE ETS-I NES EJECTOR SYSTEMS FOR 25:1 AREA RATIO ENGINE NOZZLE (PAGE II-A-30)

2-3.1(2) NES RED PROGRAM TO ESTABLISH PRIMARY \& SECONDARY PERFORMANCE FOR ETS- 1 \& ETS-2 (PAGE II-A-3O)

2-3.1A(1) NES DUCT MECHANICAL DESIGN SUPPORT OF SCALE MODEL PROGRAM (PAGEII-A-30)

$2-3.1(3) \&$ NES DUCT PRELIMINARY DESIGN, DRAWINGS COMPLETED

2-3.1 A (2) \& SPECIFICATIONS (PAGE II-A-3O)

2-3. I A (3) SELECT NES PURGE SAFETY SYSTEM (PAGE II- COMPLETED A-30)

\section{ACTUAL}

COMPLETED

COMPLETED

COMPLETED

REPORT NO.2699

REPORT NO. 2630

CHANGE ORDER NO.I, MOD. 8, RN-63013 AGC SPEC 10193 


\section{S/T 3.I NERVA EXHAUST SYSTEM ACCOMPLISHMENTS}

\section{W/S \\ REFERENCE}

$13-31$ a (2) CONT
ACTUAL

PLANNED

\author{
EVIDENCE OF \\ COMPLETION \\ MEMO 790:MO131 \\ MEETING 13 SEPT. \\ 1963 SNPO-C \& \\ REON \\ LETTER 741:0311
} MEMO 791:MOO 34

13-3.1 a (3) ENGINEERING SUPPORT OF INSTRUMENT- RERFORMED ATION \& CONTROL (I\&C) FOR STEAM SYSTEM (PAGE II-6)

13-3.1 a(4) SUBSCALE THERMAL CYCLE TEST PROGRAM COMPLETED PLAN (PAGE II-6)
MEMO 29365 (I\&C TRAILER) MEMO 791 MOO 34 STATUS REPORTS $1 \xi 2$

TWX SNDO - CTO REON TEST PLAN. 


\section{S/T 3.I NERVA EXHAUST SYSTEM}

\section{ACCOMPLISHMENTS}

$W / s$

REFERENCE B. FABRICATION

2.3.1.B

PLANNED

FABRICATION OF DUCT COOLANT PASSAGE TEST SPECIMENS (PAGE II A-3I)

13.3.1.a(1) PROCUREMENT OF STEAM GENERATOR SYSTEM (PAGE II-6)

13.-3.I.a(4) FABRICATION OF THERMAL CYCLE TEST SPECIMENS

(a) DELTA CHAMBER MOD.

(b) UNCOOLED TEST SPECIMEN

(c) COOLED TEST SPECIMEN (PAGE II -6)
ACTUAL

COMPLETED

COMPLETED

P.O.NO.NP.000254

COMPLETED

$P / N 2-088180-1 S / N$

A.42

COMPLETED

P.O.NO. 363778

COMPLETED 


\section{S/T 3.I NERVA EXHAUST SYSTEM}

ACCOMPLISHMENTS

\begin{tabular}{|c|c|c|c|}
\hline $\begin{array}{l}W / S \\
\text { REFERENCE }\end{array}$ & PLANNED & ACTUAL & $\begin{array}{l}\text { EVIDENCE OF } \\
\text { COMPLETION }\end{array}$ \\
\hline TESTING & & & \\
\hline $2-3.1 . c(1)$ & $\begin{array}{l}\text { CONDUCT STRUCTURAL TEST OF COOLANT } \\
\text { PASSAGE TEST SPECIMENS (PAGE II A-31) }\end{array}$ & COMPLETED & REPORT NO. 2668 \\
\hline $2-3.1 . c(2)$ & $\begin{array}{l}\text { CONDUCT } 1 / 4 \text { SCALE NES FACILITY SEAL } \\
\text { TEST PROGRAM (PAGE II A -31) }\end{array}$ & COMPLETED & REPORT NO. 2700 \\
\hline $13-3.1 \mathrm{a}(4)$ & CONDUCT UNCOOLED SPECIMEN TEST & COMPLETED & MEMO 790 :MO148 \\
\hline
\end{tabular}


SUBTASK 3.1 - ACCOMPLISHMENTS FOR CY 1963

Purpose and Objective

Conduct scale model tests which will provide information to develop design criteria and perform preliminary design of the NERVA Exhaust System (NES) configuration with safety purge for ETS-1, prepare criteria for the ETS-2 systems. These criteria and preliminary designs will be supported by studies of the operational and safety aspects of the NES. Technical direction and assistance will be provided for and during the final design and procurement of the duct and purge gas systems. Limited testing to support and/or verify the preliminary design will also be provided.

$2-3.1(1)$

1. Scale model tests were performed to aid in the selection of the NES ETS-I duct configuration. In order to provide sufficient data to enable selection of the most favorable configuration, eight scale models were designed, fabricated, and subjected to hot gas testing to ascertain their aerodynamic performance, heat transfer rates, and operational characteristics. The selected configuration designated the SST-2 duct geometry, a configuration with a heat flux at the elbow of $2.6 \mathrm{Btu} / \mathrm{in}$. sec. When utilized with the secondary injecior safety purge, the NES allows the E engine 25:I nozzle to flow full when the chamber pressure pressure makes approximately 230 psig. However, the NES for ETS-1 does not permit engine gimballing or altitude simulation firing startup or shutdown.

2. Report No. 2678

The selected configuration (SST-2) was further tested to determine safety purge requirements and operational behavior, such as heat rates, distribution, and the simulation of actual testing sequences. The results of the above two testing programs provided design criteria to the NES ETS-l duct preliminary design.

$2-3.1(2)$

To establish primary and secondary performance for ETS-1, ETS-2

Facilities (Report No. 2680). 
In order to predict the behavior of secondary fluid and cell pressure and to establish the secondary ejector flow requirements during the reference engine operating cycle, an analytical model was developed and scale models were tested to verify the model. This testing program confirmed the predicted behavior and interaction of the major components which comprise the exhaust sysien. $\underline{2-3.1 A(1)}$

In support of the Subscale Heat Transfer Testing Program, a conceptual design effort was performed to establish basic design concepts which served as the basis for the preliminary design of the NES duct for ETS-1. Several design approaches for the duct were generated and evaluated. As a result of the effort basic decisions made were:

1. Selection of the coolant channel configurations for each duct section

2. Establishment of basic fabrication techniques for development curing the preliminary design

3. Selection of 347 SS as the construction material.

$2-3.1(3)$ and $2-3.1 A(2)$

A preliminary design of the ETS-I NERVA Exhaust System (NES) duct, designated SST-2 Subsonic Turn Configuration, was completed in the fulfillment of Milestone No. 7 of Subtask 3.1 as defined in RN 63002. Analysis of flows, stresses, and temperatures have been performed to verify the adequacy of this design and to establish the actual configuration. Detailed calculations and backup analysis, along with the design description, has provided sufficient information to complete the preliminary design and permit proceeding with the final design. Support analysis included in the preliminary design concludes that the design is adequate and fulfills the NES ETS-I program goals.

The major products of the preliminary design were the drawings and related specifications for the NES duct.

Analyses in support of the designs and specifications were made in the following areas

1. Design

2. Heat Transfer 
3. Water System

4. Stress

5. Fabrication

6. I\&C

$\underline{2-3.1 \mathrm{~A}(3)}$

An economic evaluation of the possible safety purge systems for ETS-I was made. Based upon this evaluation and data obtained from the scale model test program, a decision was made in coordination with SNPO-C to provide a steam safety purge system for ETS-1. Detailed requirements for a steam generator system were established and an equipment specification was prepared and issued.

$\underline{2-3.1 A(4)}$

The NES Integration effort was specifically aimed toward providing the definitive data and criteria to permit the orderly integration of the several NES subsystems and to describe the overall performance band of the operational NES. The technical data and studies developed under this portion of the 3.1 Subtask considered such activities as handling, installation and removal at the test site; minimum acceptable standards for operational readiness; the operational sequence of events for startup and shutdown of the NES. Additionally, a preliminary malfunction analysis of the NES was performed to define probable modes of failure. This information will serve to establish necessary remedial procedures and to define an initial spare parts component list. Studies were also conducted to estimate the fission product plate-out to the NES duct inner wall and to formulate candidate processes of the deposited fission products.

$13-3.1$ a (2)

A list of potential steam generator suppliers was established and requests for quotations from three prospective subcontractors were solicited. Proposals were received and a detailed evaluation performed. Visits were made to each company to inspect methods of fabrication and test facilities. A subcontractor was selected and a recommendation submitted to SNPO-C. 
Coordination metings with SNPO-C and REON were held and a visit to the test site at NRDS was made to select the site location for the steam generator. Steam generator interface control drawing 093119 and facilities requirements were prepared and issued. The basic steam generator development test program was defined and discussed with SNPO-C.

\section{$13-3.1$ a (3)}

It was not expected that the facility I\&C would be operational by the time of the steam generator development test period. Therefore, an interim instrumentation system was deemed necessary. The design for such a system has been initiated. Two (2) surplus Army fire control trailers (GFE) obtained on loan basis, have been integrated into the design. The trailers have been stripped of their original electronic equipment and are being refurbished to install the instrumentation, signal conditioning, recording and controls equipment. Procurement of material for the instrumentation system has been initiated. Preliminary tabulations defining measurement points and transducer requirements have been made.

$13-3.1$ a $(4)$

A test program was initiated utilizing a Delta Thrust Chamber and subscale specimens of the ETS-I duct. Four uncooled specimens were used to determine the representative heat transfer profile. One tubular coolant passage cross-section specimen and one rectangular coolant passage crosssection specimen each of cylindrical ejector cross-section are in process of fabrication to be tested in evaluating the combined mechanical and thermal stress loads as a verification of the preliminary design studies.

This testing was accomplished by firing the Delta rocket engine into instrumented scale model specimens. A test program plan describing the testing sequence was completed.

$\underline{2-3 \cdot 1 B}$

Sample coolant channels, for possible use in the design of the ETS-I primary and secondary portion of the NES exhaust duct, were fabricated. Five specimens were constructed for this test program, three tensile specimens and two burst specimens. 


\section{$13-3.1 \mathrm{a}(1)$}

Approval of the recommended steam generator subcontractor was received from SNPO-C and procurement was initiated. P.O. Number N.P. 000254 was issued to the Thiokol Chemical Corporation for design, fabrication, and testing of the steam generator units.

\section{$13-3.1$ a $(4)$}

1. Delta Thrust Chamber Modifications

A Delta Thrust Chamber (Ser. No. A.42) was purchased and modified for acceptance of the test specimens.

\section{Uncooled Test Specimens}

In order to simulate actual heat transfer conditions, verification of the hedt transfer rates were required. Four uncooled test specimens were fabricated for testing in order to obtain representative heat transfer profiles.

\section{Cooled Test Specimen}

The fabrication of the cooled simulated duct specimens for subsequent testing was initiated in CY 1963. This specimen has coolant passages and manifolds similar to that of the final ETS-I NES duct.

$\underline{2-3.1 C(1)}$

Five sample coolant channel specimens were structurally tested. Burst and tensile testing was conducted using these specimens, and results indicated the structural capability of the coolant channel design was adequate.

$2-3.1 \mathrm{C}(2)$

A $1 / 4$ scale NES seal test program was conducted to evaluate three types of metallic seals and to determine the types that are best suited for use in the design of the ETS-I NES duct. Results indicated that a double, aluminum "Conoseal," backed by an inert gas buffer zone, will provide satisfactory sealing and safety for the NES duct operation. However, the test indicated that the present Conoseal design was unsuitable for repeated use. This report marks the completion of Item 4.3a, task 3.1 of Program Plan, RN 63002, Vol. I of Contract SNP-1. 
$13-3.1$ a (4)

Five firings at various durations up to 15 seconds were performed on the uncooled specimens to obtain a representative heat flux profile.

Conclusion

1. The work statement objectives were met.

2. All thirteen milestones scheduled in Subtask 3.1, as defined in both RN 63002 and RN 63013 (Change Order 1) were completed in CY 1963.

3. All hardware demands were completed on schedule in compliance with the updated program plan.

4. All scheduled testing was conducted and completed on schedule.

5. The objectives of this subtask have been accomplished such that final design of the NES can proceed during CY 1964. 
REPORS

I5ymber

2679

2678

2680

2699

2630

ACE- 10293

Fins 69

2658

2700

2474

\section{REON PIETSOS}

Ejugher

793:190080

$793 \div 180078$

$793: 120079$

$793=240059$

793:250067

\section{Tise}

Analyticol \& Exparinontal Eraluation of $90^{\circ}$ Subsomic Tura Ejector Syeton Por UDe at His

ENSol, IJES Percomance \& Desiga Cxitezia

Experinenta? Evaluation of Secondary Funping Systams for ExS-2

IFS Coneeptur Dosiga, Septembas 1953

HES Daci Frelimirasy Design Report \& Appandix, Soptember 1963

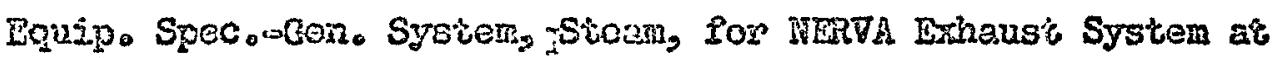
EIS 1

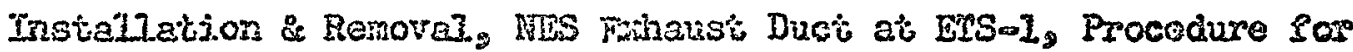

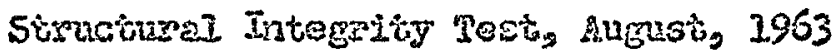

EIS-I Stibascale Seal pest Progran, October, 1963

Therral Cycle Test Plon, Septeribot 1963

AC6 2 LIS-I IUSS Preniminary Design Report

IES Duet Subwsele Thermai Stress Struebural Test Flan, September 1963

Svgjoces

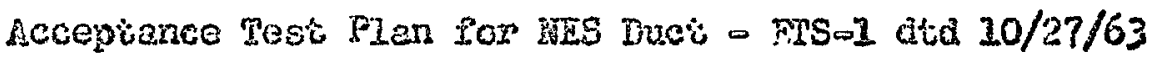

Sequence of Cperation, NES, ETS 2 did $20 / 26 / 63$

NES Prelininary Halunction Analyois ata $20 / 27 / 63$

HIS Decontantination Reporis atd $10 / 28 / 63$

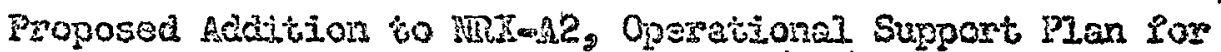
Nozzle Contratination Anelysis déa $20 / 18 / 63$ 
$: 456$ ez:

$723=20075$

$793: 120076$

$742: 10321$

$790: 30131$

$791: 150031$

798-5150042

$A C C$

SNPO

TWX

$790=120248$

Recoiving Vemo

$791: 10034$

PURCLASE ORDERS

Humber

H.P. 000254

P/N $2=088180=1$

$5 / 2$ A.42

363778
Subject

Revien of MrR-A2 Test PIan did 10/30/63

Proposed Revisions to Rrisolz Test Plan Sor Nozzle Contamination Analysis diti 10/23/63

Intersace, ETSin MRS Stean Generator atd 10/30/63

ERS I Facilitiy Requirements dta 10/9/63

Trip Report SNPO-REON Stom Cenerator System dra 6/13/63

Trip Repori o OFE, Inst. Trailers for Scs Developmont atd 10/3/63

Stacus Repoitc is \& 2 dtd $8 / 2 / 63$ and $8 / 26 / 63$ - SCS

Finutes of lieeting REOR w SNPO dit 10/23/63 - SGS

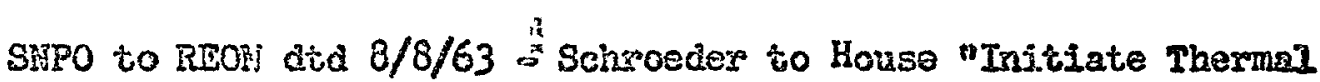
Cyolo Tesi Frogram"

Boniniy Frogress Report Thermal Cyele Test Program dta 10/1/63

Spare Mrailer Ban (SGS Instrumentation) S/ 55

Stean Generetor System Frocurement did 7/20/63

Sizject

Design, Fabsication, Inspection and Test completes SGS (Thiokol)

Delta Chamber Fabrication Redification

Thermal Cycie Test Specinans 


\section{T.}

SCHEDULES AND MILESTONES

CONTRACT YEAR 1963

TASK ITEM 3.1

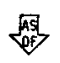

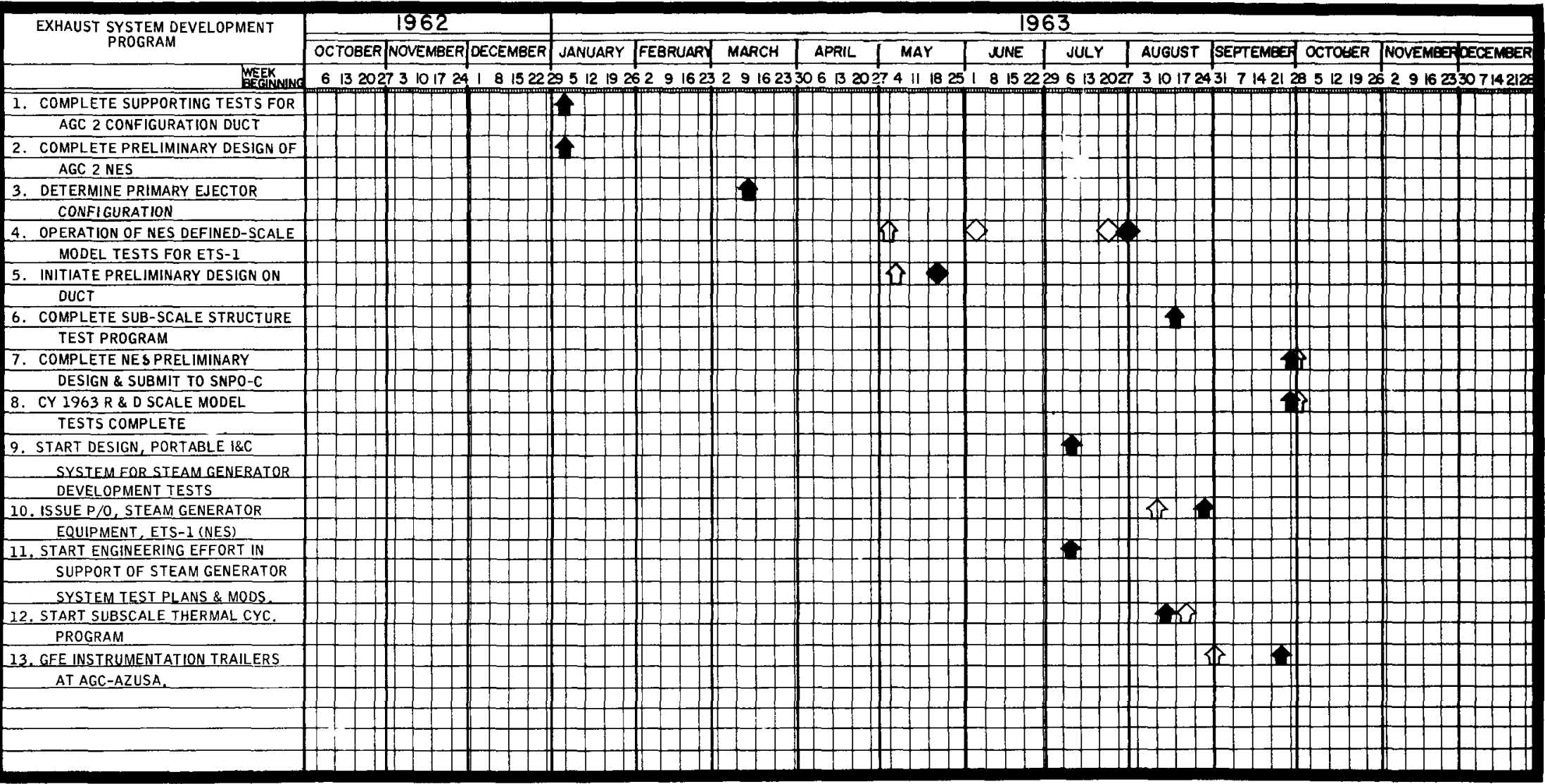

S SCHEDULED MILESTONE

$\diamond$ RESCHEDULED MILESTONE

Rescheduled to Cy 64

- MILEstone ACHIEVEMENT

RESCHEDULED MILESTONE ACHIEVEMENT

RE(D) 
RE(I)N

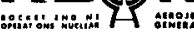

HARDWARE STATUS

$9-30-63$
TASK ITEM 3.1.8

TASK TITLE, Sub-scale Therma] Cycle Test Frogram

\begin{tabular}{|c|c|c|c|c|}
\hline COMPONENT/SUB-ASSEMBLY & END USE & EST. & ACTUAL & REMARKS \\
\hline Sub-scale Uncooled Cylinder & Devolopment Test & 1 & $4^{*}$ & Memo $746:$ B. $10: 458$ \\
\hline \multicolumn{5}{|l|}{ Test Specumen } \\
\hline Sub-scale Uncooled Rectangular & Dcvelopment Test & 1 & o* & XAn agreement wath SAIPO-C to elminate the rectangular \\
\hline \multirow[t]{2}{*}{ Test Specimen } & & & & uncooled specumen and add three additional \\
\hline & & & & cylndrical test specunens \\
\hline Sub-scale Cooled Cylinder & Developrent Test & 1 & $0 * *$ & * Drue to a design change, a change order wdS \\
\hline Test Specimen & & & & Issued to the vendor to add gussets $1 n$ the \\
\hline Sub-scale Cooled Rectangular & Development Test & 1 & $O * *$ & manzfolds and caused a three week delay in the \\
\hline Test Specimen & & & & delivery of the two cooled test specimens \\
\hline Delta AJ-10-118 Thrust Chamber & Development Test & 1 & 1 & \\
\hline & & & & \\
\hline & & & & \\
\hline & & & & \\
\hline & & & & \\
\hline & & & & \\
\hline & & & & \\
\hline & & & & \\
\hline & & & & \\
\hline & & & & \\
\hline & & & & \\
\hline & & & & \\
\hline & & & & \\
\hline & & & & \\
\hline & & & & \\
\hline
\end{tabular}


RE(C) N

\begin{tabular}{|c|c|c|c|c|c|c|}
\hline $\begin{array}{c}\text { COMPONENT } \\
\text { OR SUBASSEMBLY }\end{array}$ & \begin{tabular}{|l|} 
CONFIGURATION \\
NO. OR SERES
\end{tabular} & TEST OBJECTIVE & FACILITY & $\frac{\text { NUMBER }}{\text { EST. }}$ & $\begin{array}{l}\text { F TESTS } \\
\text { ACTUAL }\end{array}$ & REMARKS \\
\hline Sub-scale Duct & 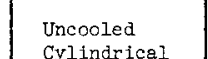 & Estabizsh Heat Flux Prof & Azusa & 2 & 5 & \\
\hline Sub-scale Duct & $\begin{array}{l}\text { Uncoooled } \\
\text { Rec tangular }\end{array}$ & Establ1 sh Heat Flux Profile & Azusa & 2 & 0 & 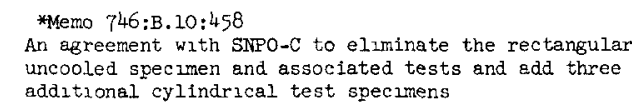 \\
\hline Delta Thrust Chember & 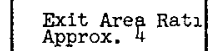 & Checkout Chamber Performance & Azusa & 1 & 2 & \\
\hline & & & & & & \\
\hline & & & & & & \\
\hline & & & & & & \\
\hline & & & & & & \\
\hline & & & & & & \\
\hline
\end{tabular}

TASK ITEM 3.1.8

TASK TITLE Sub-scale Thermal Cycle Tes Frogram
STATUS

$9-30-63$
Program 


\section{S/T 3.2 TEST STAND ETS-I}

\section{ACCOMPLISHMENTS}

W/S REFERENCE

$$
\text { PLANNED }
$$

ACTUAL

EVIDENCE OF COMPLETION

\section{$2-3.2(1)$ \\ SUPPORT TO \\ SNPO -C}

(a) PRODUCE SCHEMATICS AND DWGS FOR CONTROL SYSTEMS. PROCESS SYSTEMS AS REQUIRED

(b) PRODUCE, REVISE, EXPAND OPERATING PROCEDURES

(c) PROVIDE ACTIVATION PLANNING AS REQUESTED

2-3.2 (1) REVIEW (a) DESIGN REVIEW

TEST STAND DESIGN (b) CONDUCT STUDIES TO IDENTIFY TEST STAND MODS TO ACCEPT ENGINE/NES

(C) PERFORM SYSTEM ANALYSIS AS REQUIRED

2-3.2 (1) DESIGN CRITERIA
DEFINE ENGINE/FACILITY INTERFACES AND DEVELOP CRITERIA AS REQUIRED
(a)PERFORMED

(b) PERFORMED

(C) PERFORMED

(a) PERFORMED

(b) PERFORMED

(c) PERFORMED

PERFORMED (a) AGC DWGNOS.091035, $091036,091257,091258$

(b) L740:0035 DTD 10/17/62

(c) L741:0158 DTD 5/1/63

(a) L741:0109 DTD 3/11/63

(b) AGC REPORT 2506 DTD 6/63

(c) AGC REPORT \#2506 ADDENDUM DTD 6/18/63 NDC-65 DTD 9/19/63 L741:0309 DTD 9/19/63 AGC DWG \#091762 AGC REPORT \#2433 DTD $12 / 28 / 62$ 
Purpose and Objective

1. Support to SNPO-C

a. REON produced drawings of the test stand process and utility flow schematics. AGC Drawing Nos. 091035, 091036, 091257, 091258 were released to NTO for review and comment including a layout of the control systems composite flow schematics. One set of these schematics was transmitted to EG\&G through $\mathrm{S} /$ Task 3.3 for use in designing the I\&C wiring and control consoles.

$$
\text { b. As a continuing function Subtask } 3.2 \text { periodically re- }
$$
viewed, revised and expanded EIS-I operating procedures and countdown schedules. One revision of these procedures and schedules were incorporated as an addendum into REON Report 2506, dated June 1963.

REON also supplied various preliminary checkout procedures for Test Stand and Process Systems (ref. REON L740:0035 dated 10-12-62).

Construction contractor prepared checkout procedures for various ETS-I systems were also reviewed and commented on as the procedures became available. Comments on these procedures were returned to NRDS for action through the NERVA Test Organization.

c. Activation planning was accomplished as requested by SNPO-C. PERT data, periodically received from SNPO-C was reviewed and incorporated into REON working charts. At specific SNPO-C request (Ltr PPO/PSR dated 4-5-63) a bi-weekly reporting system was implemented by Subtask 3.2 for the E"IS-I program (Ref. REON L741:0158 5-1-63).

\section{Design Review of Modifications and Deficiencies}

a. Aetron Report No. 2403A, "Preliminary Design for Additions to ETS-1," was received and reviewed as requested by SNPO-C. Comments as to operational and safety adequacy of the contents of this report were prepared and forwarded to SNPO-C (Ref. REON Letter 1741:0109, dated 3-11-63). 
Specifications and drawings for the ETS-l fire protection system, and for specific facility additions and modifications were reviewed as a separate package and again as part of the revised facility modification package. Comments were submitted to SNPO-C each time in REON letters I741:0109 dated $3 / 11 / 63$ and $L 741: 0253$ dated $7 / 26 / 63$.

Field review, verification and correction of the test stand process and utility flow schematics was completed during this report period. Drawings of individual system schematics were initiated and completed.

Subtask 3.2 also participated in reviews of certain I\&C design packages in support of Subtask 3.3. Effort was provided in developing control room, control console and facility/graphic display layouts. The I\&C construction bid package material such as tunnel modifications, cable tray installation, etc. were reviewed (REON letter 741:508 dated 4/12/63).

b. REON Report No. 2506, "Mandatory Facility Additions, Engine Test Stand No. I at NRDS," and Addendum, "ETS-I Fluid Requirements," was completed and submitted to SNPO-C in June 1963. The report included data on the operational requirements of the NERVA engine. The Static Test Complex Utilization Plan and ETS-I Functional Requirements. The mandatory additions and modifications of the test stand were divided into the following categories:

(1) Major Contracts and Bid Packages

(2) Major Mods of Addendums required from program changes requiring an A\&E effort

(3) Systems associated with engine development

(4) Facility mods accomplished as part of activation.

A special preliminary engineering study requested by SNPO-C (Itr PPO/RWS dated 1I/20/62) was conducted to consider alternate facilities for NERVA engine testing which are not dependent on the NERVA exhaust system. The results of this study, which considered several alternate methods including upward firing were submitted in REON Report No. 2433. Coordinated efforts in subtask 3.0 and 3.6 were involved. Alternate test facilities were considered feasible. 
c. REON conducted a study to assess the feasibility of topping the EIS-1 test run tank in order to achieve an extended run time capability. This study, which included both a flow analysis and a thermodynamic feasibility analysis, was conducted to provide guidelines for ETS-I I\&C system design, and to assess the capability of the facility in supporting various test objectives. It was concluded that significant facility modifications were mandatory before ETS-I could be utilized for test runs of longer duration than the present run tank is capable of sustaining. Results of this study were submitted to SNPO-C in REON L741:0234 dated 6-26-63.

Another typical study conducted by REON was the $\mathrm{LH}_{2}$ engine cooldown facility requirements study, which was initiated when revised engine cooldown data became available in late April 1963. The results of this study were included as addendum to REON Report 2506 wherein cooldown facilities were defined and preliminary conceptual design of the $\mathrm{LH}_{2}$ and $\mathrm{LN}_{2}$ systems included.

Assistance was provided in generation of an Operational Safety Hazards Study REON Report No. 2316.

Additionally, preliminary data was developed to illustrate the feasibility of performing maintenance on a "hot" NERVA engine on the test stand and the facility support requirements associated with limited engine removal. This data is presently being used to supplement the "On Stand Maintenance" study current,ly being conducted by REON under subtask 2.I.

3. Define Engine/Facility Interfaces and Develop Criteria as Required

Considerable effort was expended by Subtask 3.2 in defining, analyzing ETS-I interfaces and producing and maintaining interface control drawings. Typical resuits of these actions are as follows:

Production of Design Criteria for $\mathrm{LH}_{2}$ Propellant Feed Line Assy, REON NDC-50, dated 10-15-62, of criteria for "Top Shield Penetration ETS-I Engine Compartment NDC-63 dated 6-28-63 were completed and submitted to SNPO-C. Criteria was generated from October 1962 until December 1962 for the NERVA Exhaust Duct System, which was later used in REON Report 2474. 
Assistance in the production of preliminary criteria for the ETS-I Thrust Structure and Thrust Structure to Engine Adapter was given to Subtask 1.1.

Subtask 3.2 assisted in establishing all NES-Facility interfaces and produced a preliminary interface drawing REON No. 093118. This drawing has been used as a guide in establishing exhaust duct requirements. All NES Design Criteria has been reviewed as it affects the operation and functional capability of the ETS-1 facility.

Another Drawing, No. 091762, was produced to further identify ETS-I facility and process system interfaces. This drawing included the Cooldown Compartment Purge interfaces, the interfaces for the disconnect for the gas back pressure actuator and the I\&C engine harness systems.

Further, a topical study of the ETS-l/ETS-2 Facility Control Interface was conducted at the direction of SNPO-C TWX 506 dated 8-9-63. This study presented methods of utilizing facilities for both ETS-I and ETS-2 and determined that only minimum changes to the I\&C system and the existing storage facilities must be made to allow common and simultaneous usage of both test stands. The results of this study were submitted to SNPO-C by REON L741:0309 dated 9-19-63.

Conclusions

The effort expended under Subtask 3.2 during CY 1963 has expedited preparations for activation of the ETS-I facility and greatly aided SNPO-C in the identification of additional requirements, needed for new internal planning and budgeting. 


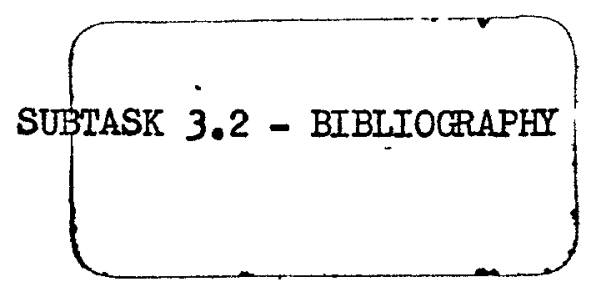

CORRESPOINDEWTE TO AND FROM REON

\begin{tabular}{|c|c|c|c|c|c|}
\hline DATH & TO & FROM & TWX 10。 & LETHWER IDO。 & SURJECI \\
\hline $10-17-62$ & SNFO-C & REON & & $\mathbf{I 7 4 0 : 0 0 3 5}$ & $\begin{array}{l}\text { Checkout Procedures for Test Stand } \\
\text { and Process Systems. }\end{array}$ \\
\hline $10-37-62$ & BNEO-C & REON & & $1741: 0045$ & Area Harnins System Sumbary \\
\hline $12-5-62$ & PREN & $\begin{array}{l}\text { NASA } \\
\text { I.RC-C }\end{array}$ & & 0321142 & $\begin{array}{l}\text { HFIS-I Supersonic Turn Configuration } \\
\text { NES }\end{array}$ \\
\hline $12-20-62$ & RTEOT & SNPO-C & , & $\begin{array}{l}\text { Draft to } \\
\text { House }\end{array}$ & Bxhasut System Actions. \\
\hline $1-10-63$ & REON & $\begin{array}{l}\text { NASA } \\
\text { S.M. }\end{array}$ & & 2343 & $\begin{array}{l}\text { Cryogenic Storage Capacities for } \\
\text { DISS-I }\end{array}$ \\
\hline $1-22-63$ & SMPO-C & REDN & & I7 $41: 0080$ & Proposed IS8-I Fucility Madifications. \\
\hline $1=5-63$ & SNEO-C & RIEON & $740-6179$ & & - Revision to AGC Report 2409. \\
\hline $2-11-63$ & REDN & SIIFO-C & & None & Preliminary Design for Addition to EIS-1 \\
\hline $2-113-63$ & SNPO-C & REDNT & $741=5263$ & $\cdot$ & 2409 Revision Report \\
\hline $2-18-63$ & REDON & SNIPO-C & & FDG :ETSM & $\begin{array}{l}\text { Nitrogen Cas Purge of Instrument Boxes } \\
\text { BIS-I }\end{array}$ \\
\hline $2-19-63$ & REEON & SNFO-C & & $\begin{array}{l}\text { TSB :AT/CEF } \\
\text { FDG :EN }\end{array}$ & $\begin{array}{l}\text { mectrical Hazard Classification of } \\
\text { ELS-1 }\end{array}$ \\
\hline
\end{tabular}


CORRESPONDEHTCE TO AND FROM REDN

\begin{tabular}{|c|c|c|c|c|c|}
\hline DATI & 20 & FROM & TWXX NOD。 & IETHYTHR 100 & SUBTECT \\
\hline $3-11-63$ & SNPO-C & RDON & & $2741: 0109$ & $\begin{array}{l}\text { REON Comments on Report No. } 2408 \text { A } \\
\text { "Preliminary Design for Additions } \\
\text { to EIS-1." }\end{array}$ \\
\hline $4-3-63$ & REDN & SNEO-C & 1539 & & EHSS-1 Piplng \\
\hline $4-5-63$ & REON & SNEO-C & & ppo-per & Preliminary ELS-1 Facility Network \\
\hline $4-10-63$ & SNFO-C & REON & & I7 $40: 0008$ & $\begin{array}{l}\text { Preliminary Facilities Instrumentation } \\
\text { and Control }\end{array}$ \\
\hline $4-12-63$ & SIFP-C & REDON & & $741-508$ & $\begin{array}{l}\text { Addition of Blast Valve to BHSS-I } \\
\text { Tunnel }\end{array}$ \\
\hline $4-30-63$ & REDN & & $\begin{array}{l}\text { ISSS/AJ/CEV } \\
3016292\end{array}$ & & $\begin{array}{l}\text { Addition of Blast Valve to BHS-I } \\
\text { Tunnell }\end{array}$ \\
\hline $5-1-63$ & SNPO-C & REON & & $1741: 0158$ & $\begin{array}{l}\text { Return of Preliminary EIS-I Facility } \\
\text { Network Copy }\end{array}$ \\
\hline $5-9-63$ & REON & & $\begin{array}{l}\text { TSS/AL/CEV } \\
\text { OT1756Z }\end{array}$ & - & $\begin{array}{l}\text { EIS-I I\&C Syatem, Vessel AS-Built } \\
\text { Hrowing }\end{array}$ \\
\hline $5-21-63$ & REON & & $\begin{array}{l}\text { TPROB/BJB } \\
221759 \mathrm{Z}\end{array}$ & & EIS-1 Gas Sybtem \\
\hline $5-22-63$ & REDN & SNFO-C & $\begin{array}{l}\text { TYPRCB/BJB } \\
\mathbf{P} 222052 Z\end{array}$ & & EIS-1 Process Water Sybtem Tegts \\
\hline $5-22-63$ & REON & $\sin 0-\mathrm{C}$ & $\begin{array}{l}\text { PILOOB/BJB } \\
\text { P 22205TZ }\end{array}$ & & $\begin{array}{l}\text { Activation of EISS-1 Process Water } \\
\text { System }\end{array}$ \\
\hline $5-24-63$ & REON & & $\begin{array}{l}\text { FDG/CJL } \\
2322492\end{array}$ & & Testing Diesel-Generator \\
\hline
\end{tabular}


CORRTESPOMDENCE TO AND FRON FEON

\begin{tabular}{|c|c|c|c|c|c|}
\hline DAIE & 20 & FFOM & TWX IDO & IEITIEXPR NO. & SUBJECL \\
\hline $5-24-63$ & REON & $\begin{array}{l}\text { IMASA } \\
\text { IRAC-C }\end{array}$ & $\begin{array}{l}\text { FIG/OJI } \\
2322452\end{array}$ & & $\begin{array}{l}\text { EMS-1 Diesel-Generator Performance } \\
\text { Data }\end{array}$ \\
\hline $6-4-63$ & SINPO-C & REON & & $1740-0023$ & $\begin{array}{l}\text { AGC/Sacto Safety Procedure No. } 3 \\
\text { Pressurized Equi pment }\end{array}$ \\
\hline $5-31-63$ & SNPO-C & Aetron & & $810: 254$ & EIS-1 Engineerling Work Incompleted \\
\hline $6-7-63$ & REON & SNFO-C & $741: 059$ & & $\begin{array}{l}\text { EMS-1 Facility Adaltion and } \\
\text { Modification }\end{array}$ \\
\hline $6-10-63$ & REDN & SINFO-C & & FDG-HAS & $\begin{array}{l}\text { HIS-1 Facllity Additions \& Modif1- } \\
\text { cations Required byNERVA Engine } \\
\text { Program Changes (mineting minutes of } \\
5-29-63 \text { at SNFO-C) }\end{array}$ \\
\hline $6-12-63$ & REON & $\begin{array}{l}\text { INASA } \\
\text { IRC-C }\end{array}$ & $\begin{array}{l}2 \mathrm{TFO} / \mathrm{BJB} \\
1221032\end{array}$ & & $\begin{array}{l}\text { Test Specification Process Water } \\
\text { System }\end{array}$ \\
\hline $6-14-63$ & FEON & $\begin{array}{l}\text { NASA } \\
\text { LRC-C }\end{array}$ & $\begin{array}{l}220 / \mathrm{BJB} \\
141812 \mathrm{Z}\end{array}$ & & Test Specification Diesel Generator \\
\hline $6-26-63$ & SNEO -C & REON & & $1741: 0234$ & InS-1 Run Tank Topping Study \\
\hline $7-12-63$ & SNIFO-C & REDON & & LT41:0251 & HDC-65, NERVA Deaign Criteria \\
\hline $7-12-63$ & REON & SNFO-C & $\begin{array}{l}\text { TPO/BJB } \\
\text { R222103Z }\end{array}$ & & $\begin{array}{l}\text { Process Water System EMS-1 Calibration } \\
\text { Test Specification }\end{array}$ \\
\hline $7-23-63$ & SIISO-C & REDN & 6179 & & EnS-1 Water Frocess \\
\hline $7-26-63$ & SIIFO-C & REON & & $1741: 0253$ & $\begin{array}{l}\text { Review of Fis:-1 Fixe Protection } \\
\text { Systems \& Facility Additions and } \\
\text { Modifications }\end{array}$ \\
\hline
\end{tabular}


CORRESFONDENCE TO AND FROM REON

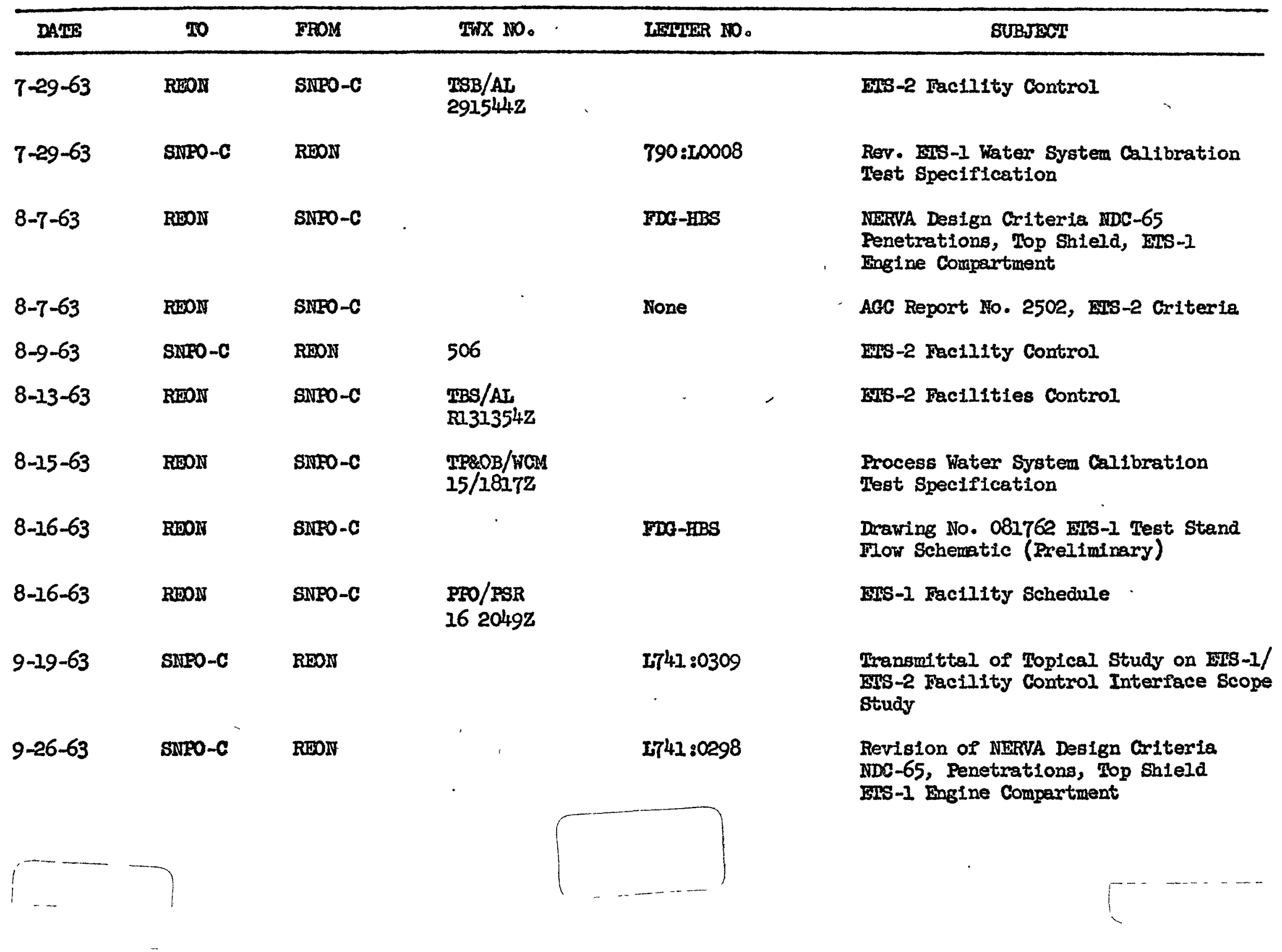


CORRESPONDDHYCE TO AND FROM REON

\begin{tabular}{|c|c|c|c|c|c|}
\hline DATE & 20 & FHOM & IWX 210 & TEXITER INO。 & SUBJECI \\
\hline $9-26-63$ & SNPO-C & REON & & IT $41: 0040$ & $\begin{array}{l}\text { EIS-1 Flre Protection System Fackege } \\
\text { Construction Specification }\end{array}$ \\
\hline $9-27-63$ & SNTPO-C & REDN & & IT41:0323 & $\begin{array}{l}\text { 8NFo-C Coments Concerning AGC } \\
\text { Drewling No. 091762 "ELS-1 Tegt Stand } \\
\text { Flow Schewatic (Preliminary)" }\end{array}$ \\
\hline $9-30-63$ & SNFO-C & REON & & IT41:0316 & $\begin{array}{l}\text { EIS-1 NERRVA Bxhaust System Steam } \\
\text { Generator Interface }\end{array}$ \\
\hline
\end{tabular}




\section{S/T 3.3 ETS-II INSTRUMENTATION \& CONTROLS}

ACCOMPLISHMENTS

\section{$W / S$}

REFERENCE

2-3.3(1) SUPPORT TO SNPO-C

(a) PROVIDE AS REQUESTED CRITERIA, EVALUATIONS, REQUIREMENTS, JUSTIFICATION

2-3.3(I) PROVIDE SUBMIT OPDP DURING CONTRACT YEAR

O'ALL PRELIM. DESIGN

2-3.3(1) TECHNICAL MAINTAIN TECHNICAL LIASON WITH SNPO-C AND LIASON

I \& C CONTRACTOR

2-3.3(1) ENGINEER- MAINTAIN TECHNICAL COGNIZANCE OF INTERFACES ING RESPONSIBILITY WITH I \&C DESIGN

2-3.3(1) OVERALL REVIEW FACILITY MODIFICATION DESIGNS, ENGINEERING MONITOR INSTALLATION AND CHECKOUT AS SURVEILLANCE REQUIRED
EVIDENCE OF COMPLETION

ACTUAL

(a)PERFORMED

(a) SEE BIBLIOGRAPHY

L741:0081 DTD 1/23/63

L741:0123 DTD 5/23/63

L741:0213 DTD 6/13/63

COMPLETED

AGC REPORT *2410

DTD $11 / 19 / 62$

PERFORMED

REON RESIDENT REPRES.

AT $A \xi E$

SEE BIBLIOGRAPHY

SEE BIBLIOGRAPHY

L741:591 DTD 7/29/63

PERFORMED

L741:0205 DTD 6/10/63

\section{REON-ROCKET ENGINE OPERATIONS-NUGLEAR}




\section{S/T 3.3 ETS-I INSTRUMENTATION $\xi$ CONTROLS ACCOMPLISHMENTS}

$W / S$

REFERENCE

2-3.3 (1) TECHNICAL PROVIDE AS REQUIRED CRITERIA

DIRECTION TO

I\&C CONTRACTOR AND DESIGN REVIEW SERVICES

PLANNED

CLARIFICATION, DETAILED REQUIREMENTS

ASSIST SNPO-C IN THE INITIATION AND INTEGRATION OF AN RQA PROGRAM WITH

I \&C CONTRACTOR
ACTUAL

PERFORMED

EVIDENCE OF COMPLETION

SEE BIBLIOGRAPHY

L 741:0104 DTD 2/20/63

L 741:0173 DTD 5/2/63

COMPLETED

\section{L741:028 DTD 8/26/63}

RELIABILITY

AND QUALITY

ASSURANCE 
Purpose and Objective

See page 3-1.

Accomplishments

1. Support to SNPO-C

a. Criteria

Special studies were conducted to define approximately

$\delta 3$ criteria and/or criteria clarifications as requested by SNPO-C. These have been reported in various letters and TWX's (see Bibliography). Typically, these were; electrical hazards definition (741:0081, 23 January 1963 to SNPO-C), emergency coolant flow measurement pipe spool design criteria (L741:0123, 24 April 1963 to SNPO-C), facility operations and control systems (L741:0082, 23 January 1963 to SNPO-C), safety alarm and warning systems (L741:0045, 31 October 1963 to SNPO-C), radio frequency communications system ( $1741: 0074$, 16 January 1963 to SNPO-C), facility modifications (L741:0080, 22 January 1963 to SNPO-C). As a consequence of these studies some technical direction to EG\&G resulted.

b. Technical Evaluations

Approximately 10 special technical evaluations were performed as requested by SNPO-C. Typical examples were the evaluation of the new LASL time code resulting in technical direction to EG\&G transmitted by Addendum No. 6 (REON letter I741:0149 dated 22 April 1963), technical evaluation of digital data system proposals (REON letter L741:0126, 29 March 1963), performance investigation of 32 track FM magnetic tape recorders provided information needed for incorporation of these units in the ETS-I I\&C design (I741:0289, 21 August 1963 to SNPO-C). Use of heated reference junctions . rather than thermocouple reference wells at ETS-I resulted in a change in the EGG design of these systems (1741:0272, 6 August 1963). 


\section{c. Technical Requirements}

Certain special requirements and definitions were submitted to SNPO-C as requested. Typically, these were the EIS-I and ETS-2 Electrical Power Generation and Distribution Requirements (L741:0299, 23 September 1963), this study resulted in clarification of criteria and was utilized in subsequent direction of EGG effort, ETS-I I\&C Phase II Drawing Lists and Procurement Specifications were produced to assist in describing the magnitude of the EG\&G Phase II effort required and define the approval/ review responsibilities.

\section{d. Justification of Technical Direction}

REON at the request of SNPO-C Justified certain Technical Direction which has been given to EG\&G. Typical examples listed in the Bibliography are: (I) use of individual power supplies (minutes of I\&C meeting No. 11, 14 June 1963); (2) Modification of Meteorological Subsystem (TWX Msg. 314, 7 June 1963 to SNPO-C); (3) Duct and Shield Monitor (Addendum 8, Letter 741:0213, 13 June 1963 to SNPO-C). This information provided to SNPO-C the basis for REON technical directives to EG\&G.

\section{e. Program Management Assistance to SNPO-C}

Management assistance was provided in the formulation of contract documents Addendum 3-8 noted in Bibliography for use in contractual direction of EG\&G. These documents were incorporated in the EG\&G contract and implemented by technical direction from REON.

\section{Overall Preliminary Design}

The Overall Preliminary Design Package was submitted as defined in the W/S and TAD. REON was requested to submit the OPDP for use during I\&C contract negotiations on 27 November 1962. REON compiled by submitting the OPDP as AGC Report 2410 on 19 November 1962.

\section{Technical Liaison}

REON provided technical liaison with the I\&C contractor by assignment of a representative at the I\&C contractor's plant in Boston during 
various phases of the design effort and by technical review meetings and field surveys. Approximately 132 man-days were expended during this period. This was exclusive of the liaison provided in design reviews of facility modifications associated wi.th I\&C requirements.

4. Engineering Responsibility

REON maintained engineering responsibility by continuous technical direction and appropriate liaison with the I\&C contractor and for the coordination of interfaces of other systems with the I\&C system. Participation in periodic Remote Engine Control meetings, Test Stand Interface committee meetings and review of various facility design packages such as Fire Protection System, Shield Design, Tunnel Blast Valve, etc., were conducted. Typical interface information was prepared and was subsequently submitted as teclnical direction and/or information to the I\&C Contractor was (I) Fire Protection Control requirements (REON letter I741:591, 29 July to EG\&G); (2) Sisnal Interfaces for REC (L741:0160, 26 April 1963 to EG\&G); (3) Shield Interface (L74I:0130, I April 1963 to EG\&G)。

\section{Overall Engineering Surveillance}

REON performed design reviews and submitted comments regarding the I\&C contractor direction of the facility modification construction bid packages. REON has received 33 documents, 288 drawings, including revised drawings, and has attended 28 design review meetings relative to I\&C influenced facility modifications. Examples of the submittals with review comments are REON letters (L741:0008 dated 6 June 1963), and (L741:0205 dated 10 June 1963), regarding the Facility Modification Criteria, T.V. and Photo Systems and Building Modifications respectively. The results of these reviews have been incorporated in the Construction Bid Packages under REON technical direction.

Although monitoring of installations and checkouts is required, no effort was expended in this area due to program status of the design in CY 1963. It is anticipated that all monitoring of installations and checkouts will be conducted in CY 1964 . 


\section{Provide Technical Direction to the I\&C Contractor}

REON performed design reviews of the I\&C contractor submittals and submitted reviews and technical direction to the I\&C contractor. During this period approximately 76 documents and 650 drawings were reviewed and commented on. In addition REON participated in 18 design review meetings and 22 official I\&C meetings involved in technical direction and program planning.

REON prepared specific technical direction to EG\&G resulting in revised system requirements, design and review, definition of and special studies as noted in Section 1. All of the T.D. actions are noted in the Bibliography. An example of this T.D. is presented by REON letter L741:0173 dated 2 May 1963 defining communication station locations.

Other examples of Technical Direction are illustrated by REON lettex ( $1741: 0104$ dated 20 February 1963) which defines comments to be incorporated in the design of ETS-I/ETS-2 control center as specifically directed by SNPO-C.

During the reporting period, 290 letters and TWX's were received from EG\&G and REON submitted 108 IWX's and 91 letters to EG\&G involving technical direction. These actions are noted in the Bibliography.

7. Reliability and Quality Assurance

(Change Order No. I to Mod No. $8(\mathrm{RN}-63013)$ )

This change order established the requirements for REON to provide R\&\&A surveillance of the overall ETS-I I\&C program.

REON reviewed and submitted comments on the EG\&G Reliability and Quality Assurance Plan. This information was transmitted in REON letter 720:RQA:L004 to SNPO-C on 9 April 1963. REON submitted technical direction document to SNPO-C for review and approval for R\&QA Program Plan in 1741:0278 dated 16 August 1963. A recommended Critical Item List for inclusion in the plan was submitted to SNPO-C in REON letter L741:0302 dated 6 september 1963).I

During this period (last quarter) REON submitted a total of

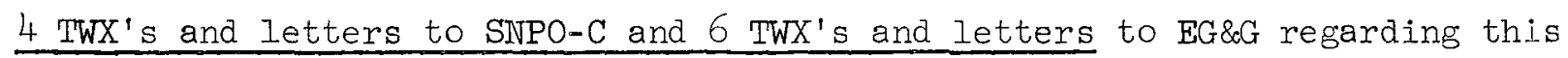
program. In addition REON participated in two I\&C R\&QA meetings. 
As a result of this REON activity a partially acceptable plan has been received by SNPO-C/REON from EG\&G. Some elements of this plan, however, require resolution by SINO-C before a complete plan can be derived and implemented by REON technical direction to EG\&G.

Conclusion

In conclusion, and as noted by the extensive bibliography, significant detailed direction was required to secure a design package acceptable to SNPO-C/REON. Redirection of EG\&G as noted in Addendum 7 dated 24 July 1963, has resulted in the production of a design package that conforms to the objectives presented during meeting No. 8 (26 April 1963). It is expected that this package will be acceptable to SNPO-C/REON with only minor revisions. 


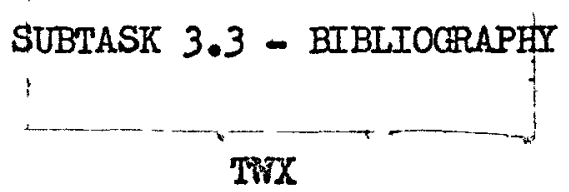

CORPESPONDENICE TO SNPO OC

TWX No.

Date

Subjeat

10.17.6́2

$10-30-62$

$11-21-62$

$1 I=21-62$

$11-27-62$

$12-17-62$

$12-17-62$

$12-27-62$
Separate ETS-2 Control Roon

Control Roor Concept

IreC Completion Schedule

I\&eC System Sehodule

Froility Ira: System Reqd. Completion

Review Agenda for Technical Direction Weeting with EGrit

I\&C System Completion Schedule

Facilities Modification Assignment and Costs 
TुW

CORRBS POATREYCE TO STPO-C

TWX No.

Date

Subject

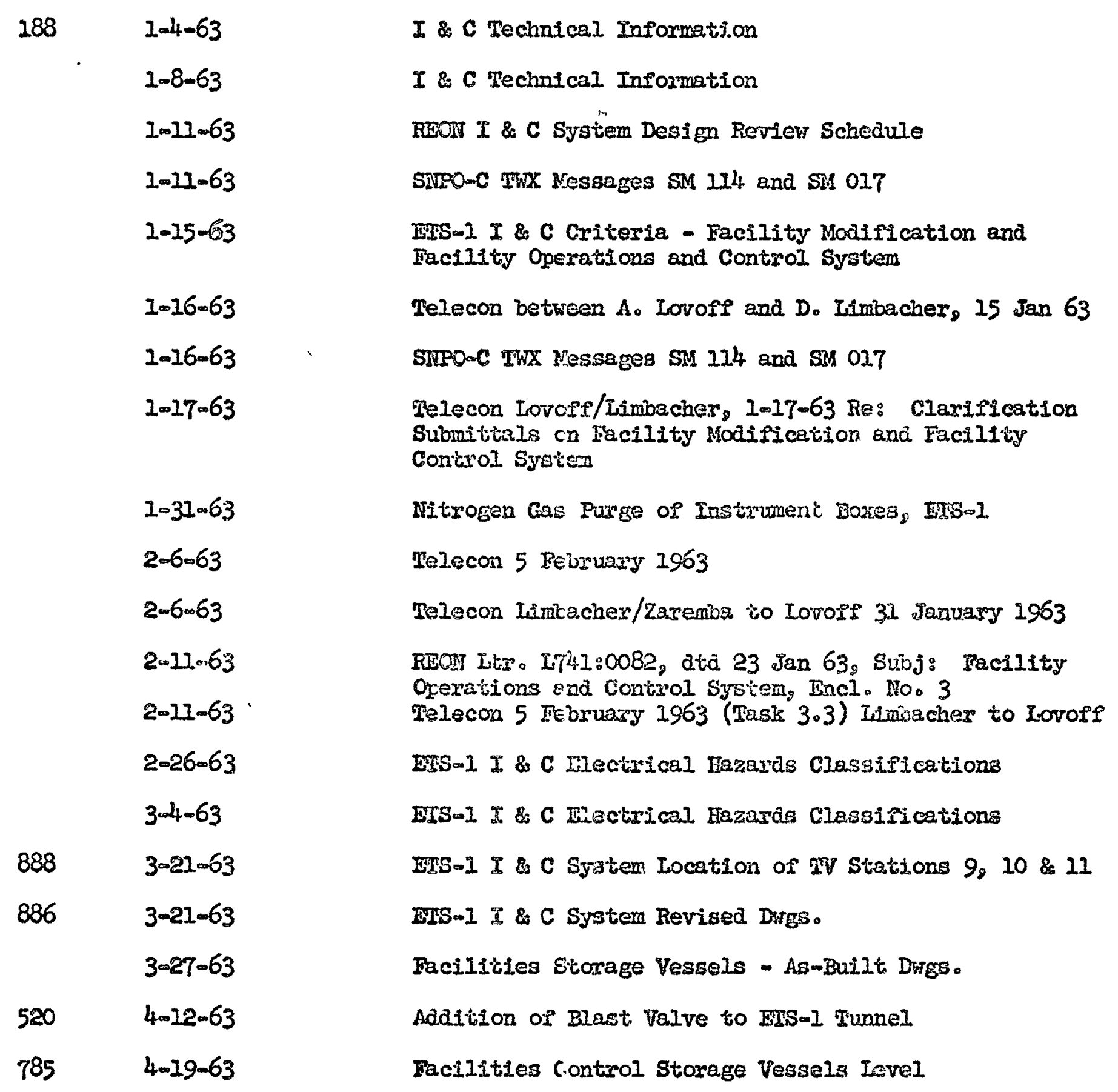

$3.3-2 a$ 


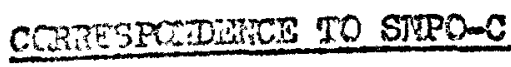

TWX No. Date Subject

$787 \quad 4-19-63$

$282 \quad 5-8-63$

$366 \quad 5-9-63$

$456 \quad 5-11-63$

$927 \quad 5-22-63$

$5-27-63$

$314 \quad 6-7-63$

$508 \quad 6-13-63$

6.20 .63

$21336-28-63$

016701063

$581 \quad 7-3-63$

$586 \quad 7010063$

$689 \quad 7-26-63$

$429 \quad 8.13-63$

$601 \quad 8015-63$

$553 \quad 8-15-63$

$594 \quad 8-16-63$

$593 \quad 8-16-63$

$592 \quad 8-16063$
ISIS-1/EIS-2 Timing Syatem

Comments on Digital System Woris Statement

EXSS-I I \& C System, Addendum No. 4 \& 5

EIS-I Diesel Cenerator Performance Data

Comments on Work Statement and Functional Specs (Rev.B) Digital Dira System

EIS-I I \& C Syctem Vessel As-Buili Durgs。

EIIS-I I \& C Meterological gover

DISS-I I \& C System As-Butlt Dirgs.

ETSal I \& C Preliminary Dasign Revised Schedule

Telecon Lovopi SNPO-C to Iimbacher RECal dtd 28 sun 63

Duct and Skield Monitors

EIS-I I \& C Design Package Review

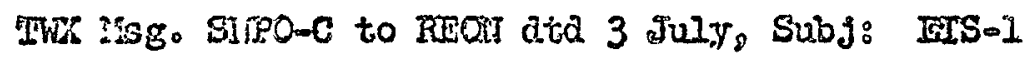

I \& C Paclige Reviev Meeting

Telecon SITPaC (Lovosp) to REOrT (Carton, Limbacher), 15 JuI 63

Attachmant $3 A$ to SIPOAC Ietiter to If \& 6 dtd 24 sul 63

Iocation of Teraninal Boxes Por Steam Generator Wire and $\mathrm{E} G$ \& 6 Interface Point

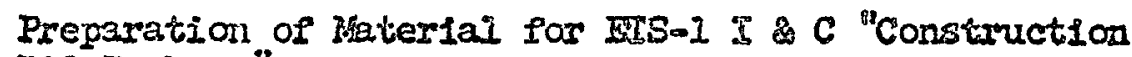
Bid Fo.cizage"

EIS-I/ExS-2 I \& C Cable Engry Estimated Requirements

Recorders for Radiation Monitoring Subsystem

EIS-1 I \& C Design Package Revision Schedule

$$
3.3-3 a
$$




TwX No. Date Subject

\begin{tabular}{|c|c|c|}
\hline 590 & $8-16-63$ & G. E. Electrical Drawings \\
\hline 756 & $8-27-63$ & Calibration Steps for Frequency Channels, ErS-I \\
\hline 026 & $9-3-63$ & $\begin{array}{l}\text { SMPO-C TWX to REOM, dtd. } 26 \text { Aug } 63 \text {, Sugj: EHIS-I I \& C } \\
\text { Wide Rand Recording System }\end{array}$ \\
\hline 0103 & $9-4-63$ & Iocation of Stean cenerators, IISS-I \\
\hline 312 & $9-10-63$ & $\begin{array}{l}\text { SHPO-C to REOS TwK, dtd } 22 \text { Aug 63, Subj: EgS-I } \\
\text { I \& C Power Distribution }\end{array}$ \\
\hline 0384 & $9-21-63$ & $\begin{array}{l}\text { Telecon Farrar (SNIFO-C)/D.Iimioacher (REOH), ErS-I } \\
\text { I \& C Design Agreerents }\end{array}$ \\
\hline $8 \times 2$ & $9-18-63$ & IIS-I Digital Dita System Worls Statement \\
\hline 2060 & $9-26 \times 63$ & 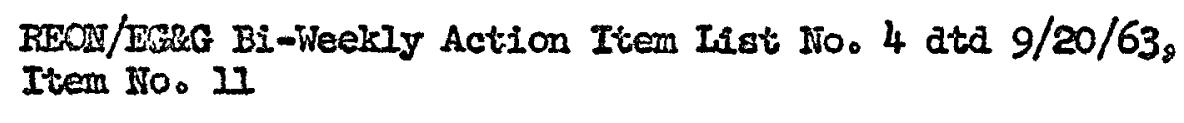 \\
\hline 1221 & $90-30-63$ & $\begin{array}{l}\text { HIS-I TP System Lighting Requirementis for Station } 9 \text {, } \\
10 \text { and } 11\end{array}$ \\
\hline
\end{tabular}

$$
3.3-4 a
$$




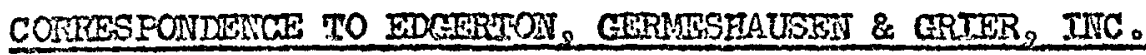

\begin{tabular}{|c|c|c|}
\hline TWX NO. & Daice & Subject \\
\hline \multirow[t]{2}{*}{845} & $12-28-62$ & Technical Direction Procedures \\
\hline & $1-7-63$ & Technical Direction Meeting of 27 December 1962 \\
\hline 299 & $1=8-63$ & I \& C Technical Information \\
\hline 335 & 1.8 .63 & $\begin{array}{l}\text { Changes \& Clariflcation of Technical Direction } \\
\text { Procedures. }\end{array}$ \\
\hline 333 & $108-63$ & E e \& C Tix Io. 3129, atd $1 / 4 / 6$ \\
\hline 334 & $2-0.8-63$ & $\begin{array}{l}\text { Action Item No. } 16 \text { I \& C Niecting No. 3, Polarization } \\
\text { of Control and Indicating Circuits }\end{array}$ \\
\hline 332 & $1-8-63$ & I \& C Technical Information Changes \\
\hline 395 & $1-9-63$ & OPDP Repsoducibles \\
\hline 633 & $1-15-63$ & Comments on Minutes of EIS-I I \& C Meetings ? and 3 \\
\hline \multirow[t]{4}{*}{652} & $1-16-63$ & E \& \& G Rep. No. $1183-3 B$ \\
\hline & $2-2-63$ & TS Functional Spec. Review Comments \\
\hline & $2-4-63$ & Drawlngs for Data Acquisition System \\
\hline & $2-4-63$ & REOT I \& C System Design Rev1sed Schedule \\
\hline \multirow[t]{2}{*}{187} & $2-6-63$ & REON I \& C System Dealgo Review \\
\hline & $2-8-63$ & I \& C Technical Review Meting \\
\hline 945 & $2-25-63$ & Dwg. ICC-OT9A, OPDP, Page 587 \\
\hline 974 & $2-25-63$ & Resolution of On-Off Indications \\
\hline 999 & $2-25-63$ & Analog Recosding System \\
\hline 998 & $2-26-63$ & Veriflcation of Cable Requirement $E_{0} C_{0}$ \& $R \mathrm{E} C$ \\
\hline 1128 & $2-28-63$ & Action Item INo. 14, Minutes of I \& C Meating No. 3 \\
\hline 270 & $3-6-63$ & Comments on Minutes of I \& $C$ Meeting No. 7 . \\
\hline
\end{tabular}

$$
3.3-5 a
$$


TWX

Correspondence to I \& \& 6

THX No. Dete Subject

\begin{tabular}{|c|c|c|}
\hline 271 & $3-6-63$ & External IJeiditronics System \\
\hline 887 & $3-19-63$ & Delay of Farility Hodifications Submittal \\
\hline 1040 & $3-20-63$ & Eis-1 1,00 C..SS Power Requirements \\
\hline 889 & $3-21-63$ & Action Item INo. 14, Minutes of is a c Neeting No. 3 \\
\hline 067 & $4-2-63$ & External Weutronies System \\
\hline 124 & $4-3-63$ & $\begin{array}{l}\text { Digital Data System, Fhase I Design, Scope of Warts } \\
\text { Statement }\end{array}$ \\
\hline 517 & $4-12-63$ & ERRG Cenerated I \& $C$ Syritem Flow Diagrauns \\
\hline 548 & $4-12-63$ & External Neuts゙onics Meesurenents \\
\hline 833 & $4-19-63$ & T. Hoore's risit to $\mathrm{E} \& \mathrm{~B}$ \\
\hline 786 & $4-19-63$ & Spacs Allocation for Additional Kinescops Recordes \\
\hline 922 & $4-23-63$ & 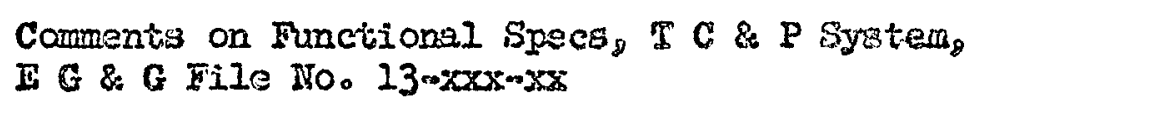 \\
\hline 1052 & $4-25-63$ & Conflrming Agreement of $E \& Q$ Submitiais to REOS \\
\hline ogit & $5-2-63$ & Comments on Funcitional Specs, T $C \& P$ Systern \\
\hline 052 & $5-2-63$ & $\begin{array}{l}\text { Acuivity Wo. } 2 \text {, Detailed System Configuxacion Exeo } \\
\text { liminary Detailed Design Specs. }\end{array}$ \\
\hline 176 & $5=6-63$ & Facility Graphic Display \\
\hline 218 & $5-6-63$ & EIS-I I \& C Fonsex Requirements \\
\hline 217 & $5-6-63$ & Fhoto Systen Munctional Spacs, File Heb-12x-03 \\
\hline 224 & $5-6-63$ & 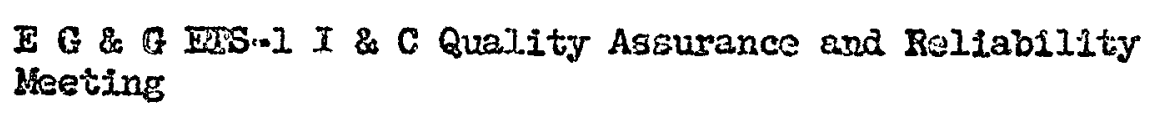 \\
\hline 223 & 506.63 & Qualitiy Assiurapce Hecting \\
\hline \multirow[t]{2}{*}{281} & $5-7-63$ & Drafting Rom Nanual \\
\hline & $5-9-63$ & 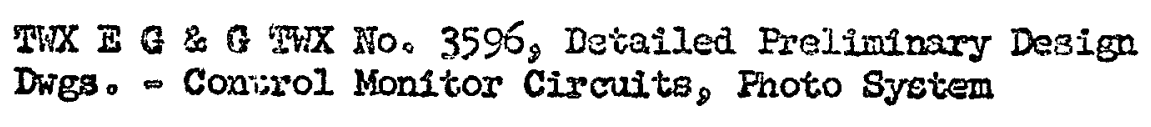 \\
\hline$\therefore$ & $\cdots$ & \\
\hline & i & $3.3-6 a$ \\
\hline
\end{tabular}


TWX

Correspondonce to $E G \& G$

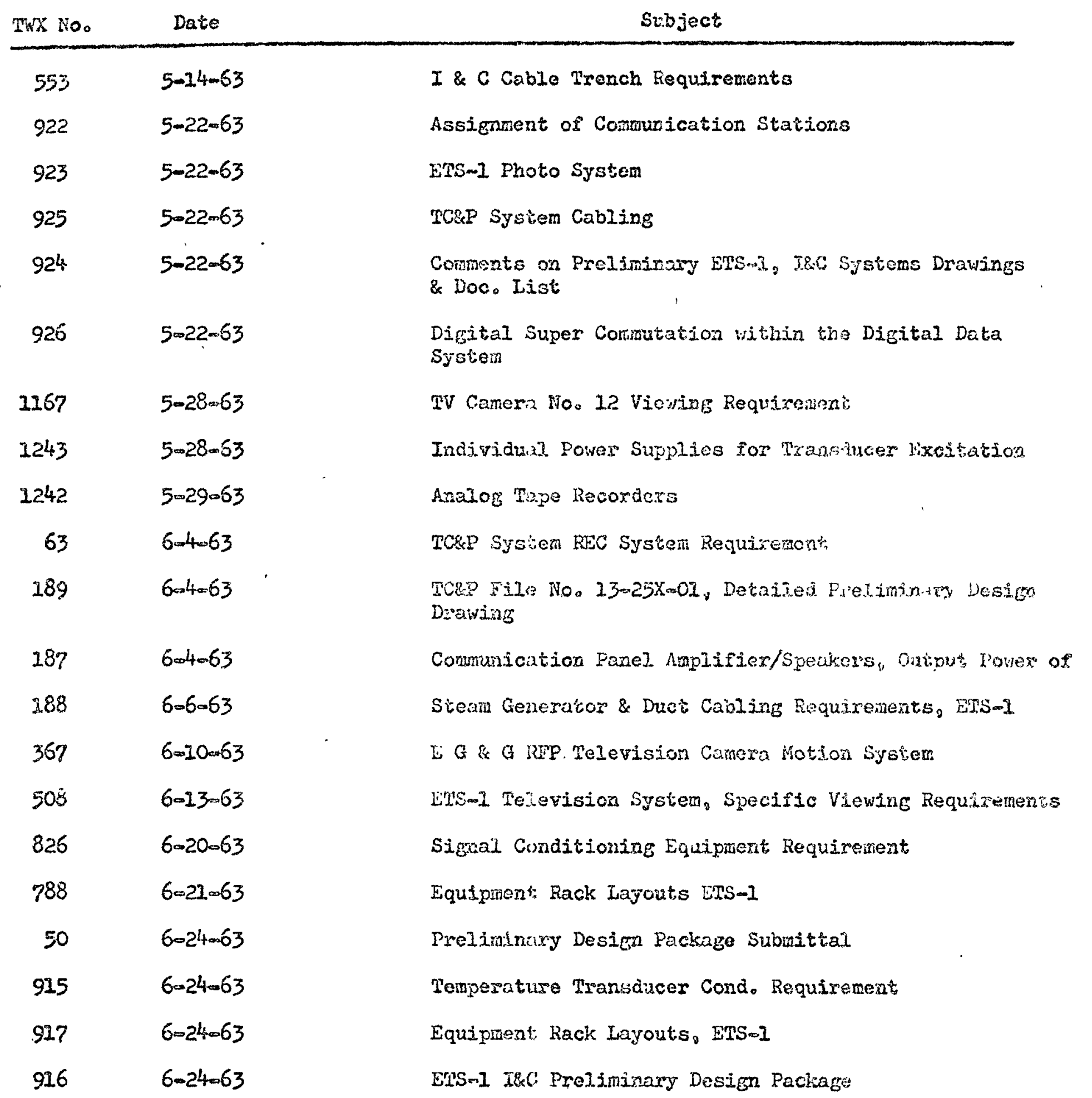

$$
3.3-7 a
$$


Correspondence to $E \mathrm{G} \& \mathrm{G}$

\begin{tabular}{|c|c|c|}
\hline TWX No. & Date & Subject \\
\hline 2048 & $6-25-63$ & TC\&P Cable Requirement Relative to Rack Relocations \\
\hline 1126 & $6-25-63$ & Safety System, Ref̂.E G \& G Tax No.4027, 8 June ${ }^{\circ} 63$ \\
\hline 1049 & $6-25-63$ & $\begin{array}{l}\text { Technical Dir: Resulting from I\&G Meeting No. } 8 \\
\text { 25-26 April } 063\end{array}$ \\
\hline 1044 & $6-25-63$ & ETS-1 TV System Station \#3 \\
\hline 061 & $6-28-63$ & Facility Control System Controller, For \\
\hline 062 & $7-1=63$ & Fire Prolection System, ETS-I \\
\hline 166 & $7-3-63$ & $\begin{array}{l}\text { ETS-I Ifo System, Llectrical Power Sep., Recording } \\
\text { Requiroment }\end{array}$ \\
\hline 135 & $7003-63$ & WETCS, Deletion of \\
\hline 275 & $7-9-63$ & Pinoto Coverage Requirements \\
\hline 580 & $7-10-63$ & ETS-I Signal Conditioning Systeân Specificatioas \\
\hline 678 & $7-16-63$ & $\begin{array}{l}\text { Test Stand Terminal, Box Faciifty Modification Final } \\
\text { Design Review, Minutes of }\end{array}$ \\
\hline$\infty$ & $7-29-63$ & Fire Protection Systen, Console Space Requirements \\
\hline 135 & $7-31-63$ & Safety System, Alarms and Recording \\
\hline 011 & $7-31-63$ & Television Systen Sensilivity \\
\hline 136 & $8-1-63$ & ETS-1 I\&C Timing System/R\&C Systen Clocks \\
\hline 132 & $8 \propto 2-63$ & Conductor Size for Special TV Cable \\
\hline 130 & $8-5-63$ & ETS-1 Control Rooni Consoles, Design Package \\
\hline 392 & $8-12-63$ & Console, Rack and Front Panel Coloxs \\
\hline 389 & $8-12-63$ & Work Statement for the ETS-I Digital Data System \\
\hline 428 & $8-13-63$ & IIS-I Design Package Drawings \\
\hline 427 & $8-13-63$ & Analog Recording System/Facility Control Systerns \\
\hline
\end{tabular}

\section{$3.3-8$}


Correspondence to E G \& G

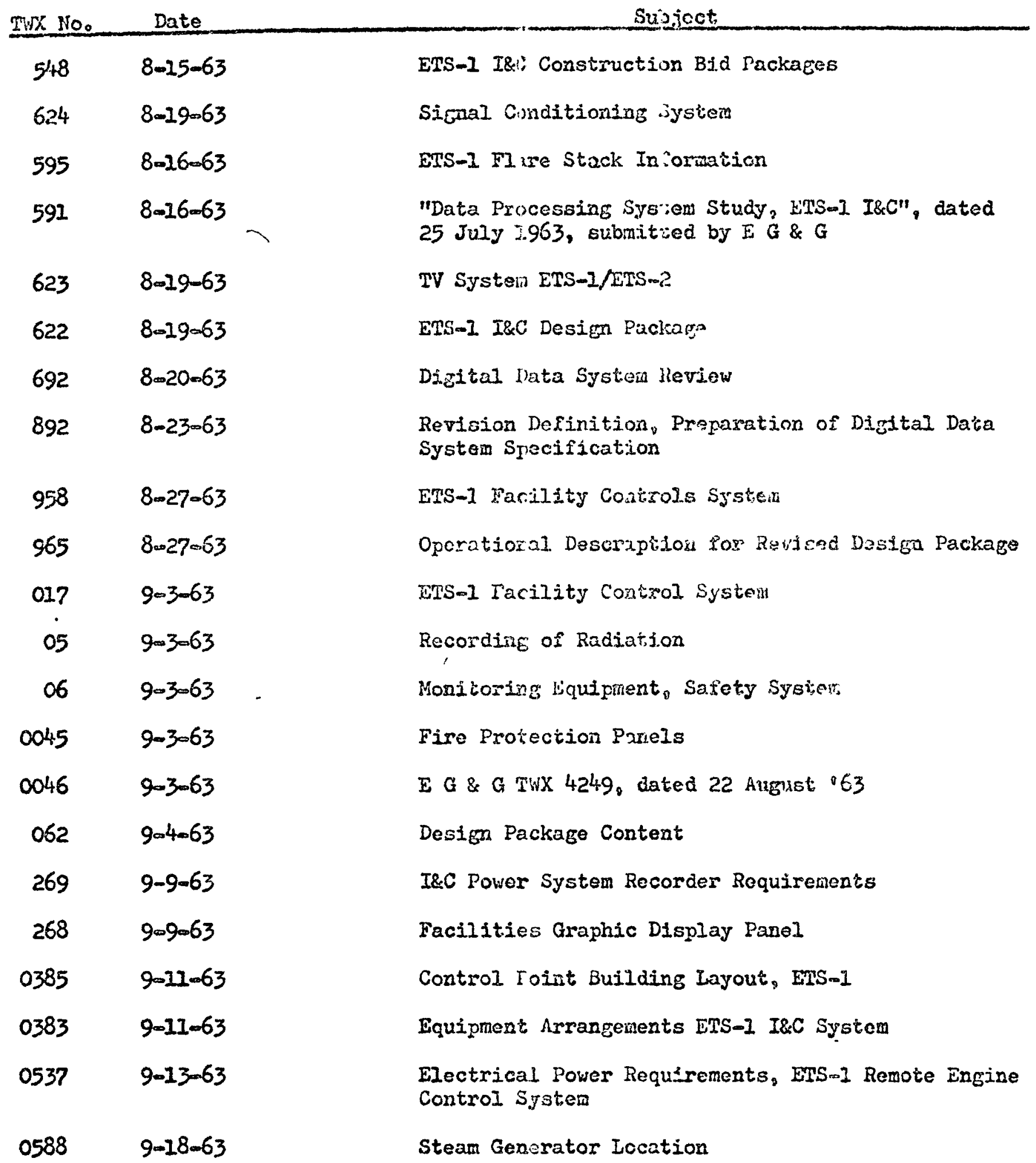


MINUTES OF I \& C MEETINGS

\begin{tabular}{|c|c|c|c|c|}
\hline Date & $\mathrm{No}_{\mathrm{o}}$ & Location & Attendanco & Topic \\
\hline 15016 Nov 62 & 1 & EGreO $\mathrm{O}_{2}$ Boston & $\begin{array}{l}\text { SNPC-C, ACC }-R E O N_{8} \\
\text { AGC-SRC'SO, EG\&EG }\end{array}$ & Prelininary organization \\
\hline $11-12$ Dec 62 & 2 & EGrG, Boston & $\begin{array}{l}\text { SIPPO-C, AGC-REON, } \\
\text { WANL, EG\&OG }\end{array}$ & $\begin{array}{l}\text { Presentation and discussion } \\
\text { of EGRe plans and schedules }\end{array}$ \\
\hline$=7-20$ Dac 62 & 3 & $\begin{array}{l}\text { AGC-Sacto } \\
\text { AGC-Azusa }\end{array}$ & $\begin{array}{l}\text { SIPO-C, WANL, } \\
\text { AGC, EGRG }\end{array}$ & $\begin{array}{l}\text { Discussion of functional } \\
\text { and operational features } \\
\text { of the ETE-1 I\&C Systen }\end{array}$ \\
\hline 27-28 Dec 62 & 4 & AGC-Azusa & $\begin{array}{l}\text { SNPO }-C, \text { EG\&ES, } \\
\text { AGC }\end{array}$ & $\begin{array}{l}\text { Correction of facility } \\
\text { control process drawings }\end{array}$ \\
\hline $21 \operatorname{Jan} 63$ & 5 & $\begin{array}{l}\text { SirPo-Cleve } \\
\text { land }\end{array}$ & $\begin{array}{l}\mathrm{SNPO}-\mathrm{C}, \mathrm{NASA}, \\
\mathrm{CCC}, \mathrm{EG} \& \mathrm{G}\end{array}$ & Control and reporting \\
\hline $29 \operatorname{Jan} 63$ & 6 & EGkG, Boston & $\begin{array}{l}\text { SNPO-C, ACC-REON, } \\
\text { WANI: EG\&O }\end{array}$ & $\begin{array}{l}\text { Discussion of data acquis } \\
\text { ition system and AGC comments } \\
\text { on TV Functional Specifications }\end{array}$ \\
\hline 13 Fob 63 & 7 & EGrea, Boston & $\begin{array}{l}\text { SNPO-C, AGC }-R E O N_{2} \\
\text { WANI, ERRG }\end{array}$ & $\begin{array}{l}\text { Action items and digital dat } \\
\text { system plans }\end{array}$ \\
\hline 25-26 Apr11 63 & 8 & EGrd, Boston & $\begin{array}{l}\text { SNPO-C, AGC-REON, } \\
\text { WANI, T,CRG }\end{array}$ & $\begin{array}{l}\text { Discussion on TWX's SINPO-C } \\
\text { TWX to EG\&G and return TWX }\end{array}$ \\
\hline 13-14 May 63 & 9 & EGRG, Boston & $\begin{array}{l}\text { SNPO-C, SNPO-W, } \\
\text { AGC-REON, IASL, } \\
\text { EGREG, Lewis RC }\end{array}$ & $\begin{array}{l}\text { ETS I IRC orientation } \\
\text { meeting }\end{array}$ \\
\hline 10 June 63 & 10 & $\begin{array}{l}\text { SNPO-Cleve } \\
\text { land }\end{array}$ & $\begin{array}{l}\text { SNPO-C, AGC-REON, } \\
\text { WAiL, Wolf R\&ED, } \\
\text { Lowis RC, EG\&G }\end{array}$ & $\begin{array}{l}\text { Discussion of ETS-I data } \\
\text { acquisition system data } \\
\text { processor and checkout fac- } \\
\text { ility equipment survey, and } \\
\text { evaluation }\end{array}$ \\
\hline 14 June 63 & 11 & $\begin{array}{l}\text { SirPO-Cleve- } \\
\text { land }\end{array}$ & 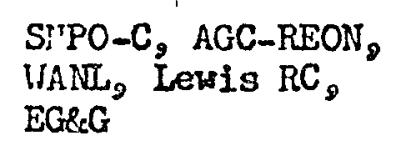 & $\begin{array}{l}\text { Clarification of transducer } \\
\text { and calibration powar suppli-3 }\end{array}$ \\
\hline $\begin{array}{l}\text { nissing? } \\
20-26 \text { June } 63\end{array}$ & 13 & $\begin{array}{l}\text { SNPO-Cleve- } \\
\text { land }\end{array}$ & $\begin{array}{l}\text { SNPO }-C_{9} A G C-R E O N_{0} \\
\text { Lewis RC, EC\&G }\end{array}$ & $\begin{array}{l}\text { I\&C System design packago } \\
\text {, reviews }\end{array}$ \\
\hline 24 June 63 & $\Perp_{4}$ & $\begin{array}{l}\text { SNPO-Cleveo } \\
\text { land }\end{array}$ & $\begin{array}{l}\text { SNPO-C, AGC-REON } \\
\text { Lewis RC, WOIf R\&E } \\
\text { EG\&G }\end{array}$ & $\begin{array}{l}\text { Discussion of the ETS-I. } \\
\text { data acquisition system, } \\
\text { data processor and checkout } \\
\text { facility equipment }\end{array}$ \\
\hline $\begin{array}{c}18-19 \text { JuIy } 63 \\
\ldots\end{array}$ & 15 & AGCøAzusa & $\begin{array}{l}\text { SNPO-C, EGre/Bos. } \\
\text { EGREG/Las Vegas } \\
\text { WANL, AGC-REON }\end{array}$ & $\begin{array}{l}\text { Presentation to EGRG of the } \\
\text { technical direction in Vol. } \\
\text { II \& III of Aerojet's comen } \\
\text { on Degign Paolege }\end{array}$ \\
\hline
\end{tabular}


NTNUTES OF I \& C MEETINGS

Date

Noo

Location

Attendance

Topic

$15-16$ Nov 62

1 EGra, Boston

SNPO-C, ACC $-R E O H$ \%

Preliminary organization AGC-Sacto, EGReG

11-12 Dec 62

2 EGret, Boston

SIPO-C, AGC-REON, WANT, EG\&G

Presentation and discussion

$\therefore 7-20$ Nag $\mathrm{K} 2$

3 AGC-Sacto,

STIPO $-C_{2}$ WANL, AGC-Azusa

$A G C$, EGRlG

27-28 Dec 62

$4 \quad$ AGC-Azusa

SNPO $-\mathrm{C}, \mathrm{EG \& G}_{\vartheta}$ AGC of EGrd plans and schedules

21. Jan 63

5 SIrPO-Cleve Iand

SNPO-C, MASA, CCC, EGReG

Discussion of functional and operational features of the ETS-1 I\&C System

$29 \operatorname{Jan} 63$

6 EGRG, Boston

SNPO $-C, A G C-R E O N$, WANL, EG\&G

Discussion of data acquis ition system and AGC comments on TV Functional Specifications

13 Feb 63

7 EGed, Roston

SNPO-C, AGC $-R E O N_{2}$ WANL, BRR

Action items and digital data system plans

25-26 April 638 EG\&G, Boston

SNPO-C, AGC-REON, Discussion on TVIX's SIIPO C WANL, TGRG

TWX to EGRG and retum TWX

13-14 May 63 9 EG\&G, Boston

SNPO-C, SIPOCW, AGC $\propto$ REON, LASL, EGRE, Lewis RC

ETS-1 IrC orientation moeting

SNPO-C, AGC-REON, WAiN, Wolf R\&E $D_{9}$

Discussion of ETS-I data

10 June 63

10. SNPO-Cleveland

Lewis $\mathrm{RC}$, EG\&G acquisition system, data processor and checkout faco ility $_{2}$ equipment survey ${ }_{8}$ and evaluation

L4 June 63

11 SIPO-CleveIand

(12 missing)

20-26 June $63 \quad 13$ SivPO-CleveIand

24 June 63

$U_{4}$

SNPO-Cleveland

SIPO-C, AGC-REON, WANL, Leivls RC,

Clarification of transducer EG\&EG and calibration power supplies

SNPO $-\mathrm{C}, \mathrm{ACC}-\mathrm{REON}$, I\&C System design package Lewis RC, EG8:G, reviews

SNPO-C ACC-REON Discussion of the ETS-I Lewis $\mathrm{RC}$, Wolf $\mathrm{R} R \mathrm{D}$, data acquisition system, EGeC: data processor and checkout facility equiprient

18-19 July $63 \quad 15$ AGCrazusa

SNPO-C, EGRE/Bos. Presentation to EGRG of the EGrof/Las Vegas WANL, AGC $-R E O N$ technical direction in Vol. $I_{9}$ II \& III of Aerojet's comments on Design Packago 


\begin{tabular}{|c|c|c|c|c|}
\hline Date & No. & Location & Atiendance & Topic \\
\hline 25 July 63 & 16 & EGRG, Boston & $\begin{array}{l}\text { SIIPO-C, AGC } \propto R E O N, \\
\text { EGRCG }\end{array}$ & $\begin{array}{l}\text { Meeting to discuss the } \\
\text { procedures and plans for } \\
\text { preparation of ETS-I IRC } \\
\text { revised design package }\end{array}$ \\
\hline 31 July 63 & 17 & EG\&G, Boston & $\begin{array}{l}\text { SIIPO-C, AGC-REON, } \\
\text { EGREG }\end{array}$ & $\begin{array}{l}\text { Reliability and Quality } \\
\text { Assurance Program Plan }\end{array}$ \\
\hline 6 Aug 63 & 18 & EGteG, Boston & $\begin{array}{l}\text { AGC-REON, HANL, } \\
\text { EGRCG }\end{array}$ & $\begin{array}{l}\text { Implementation schedulo } \\
\text { review }\end{array}$ \\
\hline \multicolumn{5}{|l|}{9 missing) } \\
\hline 27-29 Aug 63 & 20 & AGC-Az̈usa & $\begin{array}{l}\text { SNPO-C, WANI, } \\
\text { AETRON, AGC }{ }_{9} \text { REON }\end{array}$ & Discussion on IEO System \\
\hline 5 Sept 63 & $2 I$ & EGRE, Boston & $\begin{array}{l}\text { SIPPO-C, AGC॰REON } \\
\text { EGREG }\end{array}$ & $\begin{array}{l}\text { Technical Direction and } \\
\text { Coordination of Design } \\
\text { Package revision }\end{array}$ \\
\hline 9 Sept 63 & 22 & $\begin{array}{l}\text { SNPO-Cleve- } \\
\text { Iand }\end{array}$ & $\begin{array}{l}\text { SNPO-C, AGC } \text { REON } \\
\text { EGR\&G }\end{array}$ & $\begin{array}{l}\text { Discussion on catagories } \\
\text { of drawings, documents, } \\
\text { speclfications, etc. }\end{array}$ \\
\hline 14 May 63 & & $\begin{array}{l}\text { EGidG } \\
\text { Lus Vegas }\end{array}$ & $\begin{array}{l}\text { EG\&G, Boston } \\
\text { EG\&G, LasVegas } \\
\text { Aetron, AGCorEEON }\end{array}$ & $\begin{array}{l}\text { Initial Design Review } \\
\text { Mecting, TV and Photo } \\
\text { Bunker Facility } \\
\text { Modification }\end{array}$ \\
\hline 14 May 63 & & $\begin{array}{l}\text { DG\&G } \\
\text { Las Vegas }\end{array}$ & $\begin{array}{l}\text { EGRG Las Vegas } \\
\text { AGC-RIDON }\end{array}$ & $\begin{array}{l}\text { Review Meeting of EIS-l } \\
\text { Facility Control Desiga }\end{array}$ \\
\hline 5 June 63 & & $\begin{array}{l}\text { EG\&G } \\
\text { Las Vegas }\end{array}$ & $\begin{array}{l}\text { EG\&G, Las Vegas } \\
\text { Aetron } \\
\text { AGC-RDON }\end{array}$ & $\begin{array}{l}\text { Initial/Final Desiga } \\
\text { Review, Cable iray } \\
\text { facility modification }\end{array}$ \\
\hline 6 June 63 & & $\begin{array}{l}\text { Basca } \\
\text { Las Vegas }\end{array}$ & $\begin{array}{l}\text { EG\&G, Las Vegas } \\
\text { Aetron } \\
\text { AGC-REON }\end{array}$ & $\begin{array}{l}\text { Initial design review } \\
\text { test stend terminal box } \\
\text { facility modffication }\end{array}$ \\
\hline 20 June 63 & & $\begin{array}{l}\text { SNPO-C } \\
\text { Cleveland }\end{array}$ & $\begin{array}{l}\text { SNPO } C \text { E EG\&G } \\
\text { AGC }-R E O N, W A N L\end{array}$ & $\begin{array}{l}\text { Meeting on ETS-1 signal } \\
\text { conditioning system }\end{array}$ \\
\hline 21 June 63 & & $\begin{array}{l}\text { DGig } \\
\text { Las Vegas }\end{array}$ & $\begin{array}{l}\text { BG\&G, Las Vegas } \\
\text { Aetron, } \\
\text { AGC-REON }\end{array}$ & $\begin{array}{l}\text { Facility modification- } \\
\text { general-2nd and initial } \\
\text { design review meeting, } \\
\text { building modification }\end{array}$ \\
\hline
\end{tabular}

25 June 63

SNPO-C

Cleveland

SNPO-C, EG\&G-

Boston, AGC-REON

26 June 63

SNPO-C Cleveland

SNPO-C, DG8GBoston, AGC-REON
Facility control systems i.e. graphic display panelo, integration of ETS-2, Controllers, remote shut off valves. 


\begin{tabular}{|c|c|c|c|c|}
\hline Date & No. & Iocation & Attendance & Topio \\
\hline 27 June 63 & & EG\&G, Boston & $\begin{array}{l}\text { SNPO-C } \\
\text { EGRG, BOEton } \\
\text { AGC-REON }\end{array}$ & $\begin{array}{l}\text { Design review meting } \\
\text { EIS-1 I\&C System }\end{array}$ \\
\hline 19-20 June 63 & & AGC-Azusa & $\begin{array}{l}A G C-R E D N, \text { WANL, } \\
\text { BG\&G }\end{array}$ & $\begin{array}{l}\text { Meeting on signal } \\
\text { conditioning system }\end{array}$ \\
\hline 1 July 63 & & $\begin{array}{l}\text { SNPO-C } \\
\text { Cleveland }\end{array}$ & $\begin{array}{l}\text { SNPO }=C, \text { EG\&G } \\
\text { AGC } \sim \text { REON }\end{array}$ & $\begin{array}{l}\text { I\&L design activity } \\
\text { meeting }\end{array}$ \\
\hline 2 July 63 & & $\begin{array}{l}\text { SNPO-C } \\
\text { Cleveland }\end{array}$ & $\begin{array}{l}\text { AGC }- \text { REON } \\
\text { SNPO }-C_{0} \quad B G \& G_{8}\end{array}$ & $\begin{array}{l}\text { Regarding instrumentation } \\
\text { and control for ETS-1 }\end{array}$ \\
\hline 3 July 63 & & $\begin{array}{l}\text { EG\&G, } \\
\text { Las Vegas }\end{array}$ & $\begin{array}{l}\text { EG\&G, Las Vegas } \\
\text { Aetron, } \\
\text { AGC-REON }\end{array}$ & $\begin{array}{l}\text { Final design review, } \\
\text { cable tray facility } \\
\text { modification }\end{array}$ \\
\hline 8 July 63 & & $\begin{array}{l}\text { SNPO-C } \\
\text { Cleveland }\end{array}$ & $\begin{array}{l}\text { SNPO }-C_{\circledast} \text { WANL } \\
A G C=R E O N\end{array}$ & $\begin{array}{l}\text { Design package review } \\
\text { meeting }\end{array}$ \\
\hline 17 JuIy 63 & & AGC-Azusa & $\begin{array}{l}\text { SNPO-Cleveland, } \\
\text { WANI, AGC-RMON }\end{array}$ & $\begin{array}{l}\text { ENS-I I\&C system design } \\
\text { review meeting }\end{array}$ \\
\hline 18 iuly 63 & & $A G C$-Azusa & $\begin{array}{l}\text { 5NPO-Cleveland } \\
\text { AGC-REON }\end{array}$ & $\begin{array}{l}\text { EIS-I I\&C syistew design } \\
\text { reviev meeling }\end{array}$ \\
\hline II-12 JuIy 63 & & $\begin{array}{l}\text { SNPO-C } \\
\text { Cileveland }\end{array}$ & $\begin{array}{l}\text { RGC-REON } \\
\text { ACC-LRP, SNYPO-C, } \\
\text { SNPO, LASL, WANL, } \\
\text { LSWIS RC }\end{array}$ & $\begin{array}{l}\text { Feview meeting of functions } \\
\text { and operations of NERVA I\&CG } \\
\text { systems e.s proposed by ER\&G }\end{array}$ \\
\hline 19 July 63 & 15 & AGC-Azusa & $\begin{array}{l}\text { SNPO -C, ECRG-Bosto } \\
\text { IIGRG-LAS VEG E, } \\
\text { WANL, AGG-REON }\end{array}$ & $\begin{array}{l}\text { Presentation to EGGE the } \\
\text { technical direction contained } \\
\text { in Addendum } 7 \text { to ETS I ISC }\end{array}$ \\
\hline 26 Aug 63 & 19 & $\begin{array}{l}\text { EGsG-Ias } \\
\text { Vegas }\end{array}$ & $\begin{array}{l}\text { EGBG, AGS-RTOM, } \\
\text { AEIRON, SNPO-C, } \\
\text { SINO -N, NVPO-N, } \\
\text { WANL }\end{array}$ & $\begin{array}{l}\text { Coordination of ETS-l con- } \\
\text { struction bli package activities }\end{array}$ \\
\hline 28 Aug 63 & & AGC-Azusa & $A G C-2 B E O N$ & $\begin{array}{l}\text { Witeting on remote engine } \\
\text { control coordination }\end{array}$ \\
\hline 10 Sept 63 & & $\begin{array}{l}\text { EG\&G- } \\
\text { Las Vegas }\end{array}$ & $\begin{array}{l}\text { WANT, AGC-REON } \\
\text { EG\&EG }\end{array}$ & $\begin{array}{l}\text { Discussion of revision of design } \\
\text { package as listed in Addendum } 7\end{array}$ \\
\hline & & & $.3-13 a$ & $\ldots$ \\
\hline
\end{tabular}




\section{TWX'S}

CORRESPONDENCE TO EDGERTON, GERHESHAUSEN \& GRIER, INC。

\begin{tabular}{|c|c|c|}
\hline TWX NO & DATE & SUEJECT \\
\hline 845 & $12-28-62$ & Technical Division Procedures \\
\hline - & $1-7-63$ & Technical Division Meeting of 27 December 1962 \\
\hline 299 & $1-8-63$ & I\&C Technical Information \\
\hline 334 & $1-8-63$ & Changes and Clarification of Technical Direction Procedures \\
\hline 333 & $1-8-63$ & EG\&G TWX \#3129 dated 1-4-62 \\
\hline 334 & $1-8-63$ & Action Item No. 16, I\&C Meeting 3 - Polarization of \\
\hline 332 & $1-8-63$ & I\&C Technical Information \\
\hline 395 & $1-9-63$ & OPDP Reproducibles \\
\hline 633 & $1-15-63$ & Comments on Minutes of ETS-I I\&C Heetings 2 and 3 \\
\hline 652 & $1-16-63$ & EG\&G Report No. $1183-3 \mathrm{~B}$ \\
\hline- & $2-2-63$ & TV Functional Spec. Review Comments \\
\hline - & $2-4 \infty 63$ & Drakiags for Data Acquisition System \\
\hline$\infty$ & $2-4-63$ & REON I\&C Systen Design Roview Schedile \\
\hline 187 & $2-6-63$ & REON I\&C Systein Des. Review \\
\hline- & $2-8-63$ & I\&C Technical Review Meeting \\
\hline 945 & $2-25-63$ & Drawing IUC-OP) A, OPDP, Pagre 587 \\
\hline 974 & $2-25-63$ & Mesolution of On-lff Indications \\
\hline 999 & $2-25-63$ & Analog Recording System \\
\hline 998 & $2-26-63$ & Verification of Cable Requirements $E_{0} C$ \& REC \\
\hline 1228 & $2-28-63$ & Action Item No. 14, Minutes of I\&C Meeting No. 3 \\
\hline 270 & $3-6-63$ & Comments on Minutes of I\&C Meeting No. 7 \\
\hline 272 & $3-6-63$ & External Neutronics System \\
\hline 887 & $3-29-63$ & Delay of Facility Mods. Submittal \\
\hline 1040 & $3-20-63$ & EIS-1 400 CPS Poner Reyujrenents \\
\hline 889 & $3-21-63$ & Action Item No. 14, Minutes of I\&C Meeting No. 3 \\
\hline$\infty 67$ & $4-2-63$ & External Neutronics System \\
\hline 124 & $4-3-63$ & Digital Data Sysiem, Phase I Dsn, Scope of Work Statement \\
\hline 517 & $4-12-63$ & DG\&G Generated I\&C Sytem Flow Diagrams \\
\hline 548 & $4-12-63$ & External Neutronics Measurements \\
\hline$t^{\cdots-}$ & $\cdots$ & $\cdot$ \\
\hline 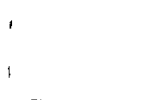 & & $\int_{-\infty}^{-\infty}$ \\
\hline
\end{tabular}


TWX:S

CORRESPONDENCE TO EDGERTON, GERHESHAUSIN \& GRIER, INC.

\begin{tabular}{|c|c|c|}
\hline ThX NO. & DATE & SUBJECI \\
\hline 833 & $4-19-63$ & To Moore's Visit to EG\&G \\
\hline 786 & $4-19-63$ & Space Allocation for Additional Kinescope Recorder \\
\hline 922 & $4-23-063$ & $\begin{array}{l}\text { Comnents on Functional Specs. GC\&P System, } \\
\text { EG\&:G File No. } 13-x 0 x-x \times x\end{array}$ \\
\hline 1052 & $4-25-63$ & Confirming Agreement of EusG Submittals to REON \\
\hline 074 & $5-2-63$ & Comments on Functional Specs. GC\&P System \\
\hline 052 & $5-2=63$ & $\begin{array}{l}\text { Activity No. 2, Detailed System Configuration Preliminary } \\
\text { Detailed Design Specso }\end{array}$ \\
\hline 176 & $5-6-63$ & Facility Graphic Display \\
\hline 218 & $5-6-63$ & ETS-I I\&C Power Requirementi \\
\hline 217 & $5-6-63$ & Photo System Functional Specs, File \#26-12x-03 \\
\hline 224 & $5-6-63$ & EG\&G ETS-I T\&C Quality Assurance and Reliability Meeting \\
\hline 223 & $5-6-63$ & Quality Assurance Meeting \\
\hline 281 & $5-7-63$ & Drafting Room Manual \\
\hline$\infty$ & $5-9-63$ & $\begin{array}{l}\text { TWX Eg\&G TWX } 1 / 3596, \text { Detailed Preliminary Design Drawines } \\
\text { Control lionitor Circuits, Photo System }\end{array}$ \\
\hline 553 & $5-14-63$ & I\&C Cable Irench Requirements \\
\hline 922 & $5-22-63$ & Communication Stations, Assignment of \\
\hline 923 & $5-22-63$ & ETS-1 Photo Systen \\
\hline 925 & $5=22-63$ & GC\&P System Cabling \\
\hline 924 & $5-22-63$ & $\begin{array}{l}\text { Comments on Preliminary EIS-I, I\&C Systems Drawings } \\
\text { and Document List }\end{array}$ \\
\hline 926 & $5-22-63$ & Digital Suger Commutation Within the Digital Data System \\
\hline 2167 & $5-28-63$ & TV Camera No. 12 Viewing Requirement \\
\hline 1243 & $5-28-63$ & Individual Power Supplies for Transducers Excitation \\
\hline 1242 & $5-29-63$ & Analog Tape Recorders \\
\hline 63 & $600-6-63$ & TC\&P Systen REC System Requirement \\
\hline 189 & $6-4-63$ & $\begin{array}{l}\text { TC\&P File No. 13-25x-0., Detailed Preliminary Design } \\
\text { Drawing }\end{array}$ \\
\hline 187 & $6-4-63$ & Communication Panel Amplifier/Speakers, Output Power of \\
\hline 188 & $6-6 \times 63$ & Steam Generator and Duct Cabling Requirements, EIS-1 \\
\hline
\end{tabular}


CORRESPONDLNCE TO EDCERTON, GERMESHAUSEN \& GRIER, INC。

\begin{tabular}{|c|c|c|}
\hline IfX 100 & DATS & SUEJLCR \\
\hline 357 & $6-10.63$ & EGRG RFP Television Camera hotion Systen \\
\hline 508 & $6-13.63$ & IrSul Television Systom, Spocinic Viewing Requirenonts \\
\hline 826 & $6-20.003$ & Signal Conditioning Equipnent Requirercnts \\
\hline 788 & $6021=63$ & Equiprent Rack Layouts ETSw 1 \\
\hline 50 & $6-24-63$ & Prelininary Design Package Submitial \\
\hline 925 & 60.24 .63 & Merperature Transducer Condicion Pequirenezi \\
\hline 817 & $6 \sin 24-63$ & Equipment Rack Layouts, ElSw \\
\hline 926 & $6 \mathrm{em} 24063$ & ETSaI IRC Preliminary Design Package \\
\hline 2048 & $60-25063$ & TCRP Cable Requirement Rolative to Rack Relocations \\
\hline 1126 & $6-25-63$ & Sarety Systcin, ReE。 EGRG TWK H4027, 8 June 2053 \\
\hline 1049 & $6-25-63$ & $\begin{array}{l}\text { Technicel Discussion Resulting fo: I\&O Meetivg No. } 8 \\
\text { 25-26 April } 1963\end{array}$ \\
\hline 2044 & 6025063 & EISal IV Systera Ste H3 \\
\hline 052 & $6-28=63$ & Faciiity Control Systcm Controlle:, For \\
\hline 0,52 & $7-10063$ & Fire Protectioa System, LISal \\
\hline 266 & $7-3-63$ & $\begin{array}{l}\text { IIS-I IRC System, Hectrical Powor System, } \\
\text { Recording Requiverouts }\end{array}$ \\
\hline 335 & $7=3-63$ & NETCS, Deietion of \\
\hline 275 & 709063 & Photo Coverage Requirenents \\
\hline 580 & $7-10=63$ & EISol SigraI Conationiag System Specificariens \\
\hline 678 & $7-16-63$ & $\begin{array}{l}\text { Toot Stand Terwial. Jox Facility hodification } \\
\text { Finas Destgn Revicu, Hitutes of }\end{array}$ \\
\hline 009 & $7=29=53$ & Firo Protoction Syston, Conse... Spoce Requiremonto \\
\hline 235 & $70-31006$ & Safety System. Alazms and Recorchas \\
\hline 0.1 & $7-31-053$ & Television System Sensitivity \\
\hline 136 & $8-1-63$ & EISaI I\&C Timine Systow/RzC SJatem Clocko \\
\hline 231 & $8-2-63$ & Conductor Size for Special TV Cable \\
\hline 130 & $8-5-63$ & ETSal Control Roon Consoles, Desigm Package \\
\hline 392 & $8-0.12=63$ & Console Rack and Front Fanel Colora \\
\hline 389 & $8-22-63$ & Work Statement for the ETSul Digitiai Data Systiva \\
\hline 428 & $8-13-63$ & ETSal Design Package Daarings \\
\hline
\end{tabular}

$$
3.3-16 a
$$


TwX'S

CORRESPONDENCE TO EDGLRTON, GERNESHAUSEN \& GRIER, INC。

\begin{tabular}{|c|c|c|}
\hline TWX NO. & DATE & SUBJECT \\
\hline 427 & $8-13-63$ & Analog Recording System/Facility Control Systems \\
\hline 548 & $8-15-63$ & ETS-I I\&C Conetruction Bid Packages \\
\hline 624 & $8-19-63$ & Signal Conditioning System \\
\hline 595 & $8-16-63$ & EIS-I Flare Stock Information \\
\hline 591 & $8-16-63$ & $\begin{array}{l}\text { "Data Processing System Study, ETS-I I\&C," dated } \\
25 \text { July 1963, Submitted by EG\&G }\end{array}$ \\
\hline 623 & $8-19-63$ & TV system MIS-1/EIS-2 \\
\hline 622 & $8-19-63$ & ETS-I I\&C Design Package \\
\hline 692 & $8-20-63$ & Digital Data System Review \\
\hline 892 & $8-23-63$ & $\begin{array}{l}\text { Revision Definition, Preparation of Digital Data } \\
\text { System Specification }\end{array}$ \\
\hline 958 & $8-27-63$ & ENS-1 Facility Controls System \\
\hline 965 & $8-27-63$ & Operational Description for Revised Design Package \\
\hline 017 & $9-3-63$ & ETS-l Facility Control Syoted \\
\hline 05 & $9-3-63$ & Recording of Radiation \\
\hline 06 & $9-3-63$ & Nonitoring Equipment Safety Systen \\
\hline$\infty 045$ & $9-3-63$ & Fire Protection Panels \\
\hline$\infty 46$ & $9-3-63$ & EG\&G TWX fr4249, dated 22 August 1963 \\
\hline 0.52 & $9=4-63$ & Design Package Content \\
\hline 269 & $9-9-63$ & I\&C Power System Recorder Requirementis \\
\hline 268 & $9-9=63$ & Facilities Graphic Display Panel \\
\hline 0385 & $9-11-63$ & Control Point Building Layout, ETS-1 \\
\hline 0383 & $9-11-63$ & Equipment Arrangements BrS-I I\&C Systow \\
\hline 0537 & $9-13-63$ & $\begin{array}{l}\text { Electrical Power Requirements, EIS-1 Remote Engine } \\
\text { Control Systen }\end{array}$ \\
\hline 0588 & $9-18-63$ & Steam Generator Location \\
\hline
\end{tabular}

$$
3.3-17 a
$$


ITHWISTS

CORTESPONDENCE TO SNPO-C

Ietter No. Date

Subject

0067

00740074

0080

$1-22-63$

0081

$1-23-63$

$0082 \quad 1-23-63$

$0083 \quad 1-24-63$

0086

0087

$2-1-63$

0128

0136

0123

$4-26-63$

0162

$4-26-63$

$0172 \quad 5-2-63$

0265

0147
$5-2-63$

$5-8-63$
Submittal of comments and requirenents relative to the Design Submitial Schedule presented by wwon at meeting of 11 - 12 December 1962 at I5 G \& G

Submittal of clarification of functional and operational requirements for the Radio Irequency Cormunlcations Sygiem for EIS-1

Items contained within Proposad Eus-I Facility Modio fications, Appendix 4.5 I \& C System Desigm Criteria

Flectrical Razard Definition, ErS-I I \& C Design

Fac1lity Opzrations and Control Systems

Transwittal of Preliminary Dasign Submittal w/comments far IV System

Transmittai of Corments on Final Functional Speciflcation for Photo System

Transmitial of Reproducible Copy of the EIS-1 Control Point Blag. I. \& C Equipment Proposed Iayout

Mransmittal of REOS DNg. TCC-028J, Engine Test Stand Flow Schematic

Transmittal of Dwg. No. 091035 Composite Flow Dlagrasn Frocess System

Design Criteria, Bnergency Coolant Flow Keasurement Pipe Spool, Transmitical of

Safecy Warning System

ETS-I I \& C Program Requirements Direction

Transmittal of Addendum No. 6 - Els-I I \& C Criteria, Timing Syatan

Transmittal of AdCisndum 4 \& 5, I \& C System Design Criteria

$$
3.3-18 a
$$



Letter No.
Date
Subject

\begin{tabular}{|c|c|}
\hline 0189 & $5-25-63$ \\
\hline 0212 & $6-5-63$ \\
\hline 0213 & $6-13-63$ \\
\hline 0234 & $6-25-63$ \\
\hline 0257 & $7-30-63$ \\
\hline 0265 & $7-29-63$ \\
\hline 0266 & $7-29-63$ \\
\hline 0267 & $7-29.63$ \\
\hline 0272 & $8-6-63$ \\
\hline 0284 & $8-15-63$ \\
\hline 0289 & $8-21-63$ \\
\hline 0292 & $8-26-63$ \\
\hline 0287 & $9-4+63$ \\
\hline 0291 & $9-4.63$ \\
\hline 0295 & $9-11-63$ \\
\hline 0300 & $9-20-63$ \\
\hline 0296 & $9-26-69$ \\
\hline 0297 & $9-23-63$ \\
\hline 0320 & $90023-63$ \\
\hline 0322 & $9-26-63$ \\
\hline 032 & $9-27-63$ \\
\hline
\end{tabular}

EIS-I I \& C System IV Station 12

Diesel Generator Test Plan

Duct \& Shield Monitors, Addendum No. 8

ETSS-1 Run Tank Topping Scuudy

Recomendation of Kinescope Recorders for tha EIS-1 I \& C Sybtens

Minutes of MERVA I \& C Meeting 21 - 12 July 1963

Minutes of ITS-I I \& C Desiga Reviet Meating $17-18 \mathrm{Ju} 1 \mathrm{y} 1963$

Ninutes of IISS-1 I \& C Technical Direction keeting 价15, 19 aruly 1963

Justirication for Utilizing Heated ReP. Junetions Rather than Thermocouple Ref. Wells at ErSS-1

Dys-I I \& C System REON BiaWaekly Action Itam Ifst

Performance Investigation of 32-Tracts Fol.Nagnetic Tape Recorders for Use at ETS-I

Eris-I I \& C Syztom RECN Bi-Weelely Action Itam Iist fto SETPOC TWX TSS-AG/CES atd 20 Jume 163 , Subject: HIS-1 I 3 C SIPO-C Coments on Addenda No. $l_{9} 5,6$.

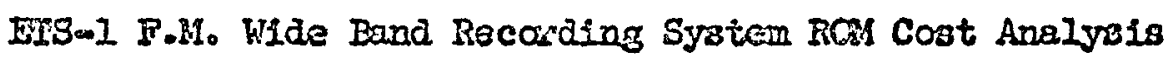

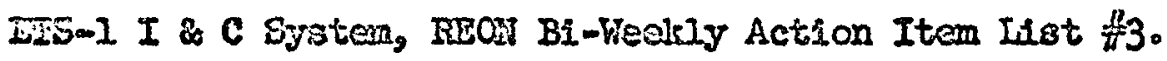

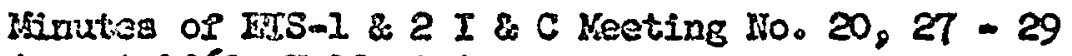
Auguat 1963, Held at Azusa

Two Caterpillar Nodel 397 Diesel Gen. Sets, Propoeed far Fiss-1 \& 2 Instrument Bus

FIS-I \& 2 Elect. Power Cen. \& Dist. Requiramont Critoria

DES-I I \& C System, RRON Bi-Weekly Action Item Iist No.4. Proposal for Use of Trailer Mounted Diesel

SNPOWC Comments Concerning AGC Diffo No. 091762 "EIS-1 Test Stand Flow Schematic (Prel.) 
LETTERS

CORHESPONDENCE TO EDGERTON, GERMESHAUSEN \& GRIER, TNC 。

\begin{tabular}{|c|c|c|}
\hline IETTER NO. & DATE & SUBJECT \\
\hline & & . \\
\hline L0062 & $i 2=28=62$ & $\begin{array}{l}\text { REON Clarification of the intent behind the } \\
\text { requirement of the ETS-I I\&C Sep. Dsg. Crito }\end{array}$ \\
\hline 1.0063 & $12-28-62$ & $\begin{array}{l}\text { Transmittal of ETSwl isc Sep. Documeniation } \\
\text { Flow Diagrams. }\end{array}$ \\
\hline L0064 & $12-32 \times 62$ & $\begin{array}{l}\text { Tranamittal of Report No. } 2320 \text { Instrunentation } \\
\text { Data Book. }\end{array}$ \\
\hline L0068 & $1-10-63$ & $\begin{array}{l}\text { Transmittal of } 1 \text { set repioducabies of alit } \\
\text { dwgs. in the ETSol I\&C Criteria dated Juno } \\
1962 \text { and the Overall Preliminary Design Packago } \\
\text { Report } 211 J_{2} \text { dated November } 1962 \text { and Dugo } \\
\text { Number Listo }\end{array}$ \\
\hline$L 0069$ & $1-11-63$ & $\begin{array}{l}\text { Transmittal of gappless. Read Tape Format in } \\
\text { responso to request made in tech. Mtg. No. } 3 \\
\text { at Sacto. }\end{array}$ \\
\hline L0072 & $1-14=63$ & $\begin{array}{l}\text { official correction of F。D.B. } 501.1 \text { as modifled } \\
\text { in Tec。 Diro Mtgo No. } 30\end{array}$ \\
\hline L0077 & 1017063 & $\begin{array}{l}\text { Transmittal of overall Preliminary Design } \\
\text { Package }\end{array}$ \\
\hline L0088 & $2-5-63$ & $\begin{array}{l}\text { Transmital of Corments on Final Functional } \\
\text { Specifications for Electrical Power System. }\end{array}$ \\
\hline L0089 & $206-63$ & $\begin{array}{l}\text { Transmittal of Commerts on Final Functional } \\
\text { Specs. for Nuclear Effects Test Capability } \\
\text { Systom. }\end{array}$ \\
\hline L0090 & $2-0.063$ & $\begin{array}{l}\text { Radie, Frequency Communications System, Functionel, } \\
\text { \& Operational Requirements. }\end{array}$ \\
\hline L0094 & $2-8-63$ & $\begin{array}{l}\text { Transmittal of Comments on Functional Specs. } \\
\text { for Events Recording System. }\end{array}$ \\
\hline L0095 & $2-8.63$ & $\begin{array}{l}\text { Transmittal of Comments on Final Functional } \\
\text { Specifications for Conmunications Systens. }\end{array}$ \\
\hline L0097 & $2-11-63$ & $\begin{array}{l}\text { Transmittal of Comments on Functional Specs. } \\
\text { Por Signal Conditioning System. }\end{array}$ \\
\hline & & ' \\
\hline
\end{tabular}


LETTER NO. DATE SUBJECT

L0092

$\mathbf{L 0 0 9 9}$

L0100

L0101

LO104

20105

10107

Lonis

10317

$\operatorname{Lo1} 35$

LOI42

20218

10019

LOL20

LOIII

L0115
2-12-63 Requests for Identity Numbers for skctches, charts, schedules etco, and drawing revision numbers.

2-12063 Transmitial of Comentis on Functional Specificas tions for ijgital Data Systom。

2-12-63 Transmitial of Comments on Furctional Specifica tions for Data Acquisition Systeno

2012063 Transmittal of Comments on Functional Specificas tions for Analog Recording Sysiem.

2-25-63 Transmitta? of Reproducibie Copy of REON Drawing ICC $-204 \mathrm{~B}$.

2m?6-63 Transmittal of Supplemental Comment Sfieecs.

305-63 Transmitta of ETSol Data Acquisfition System Computer Requiroments.

3=6-63 Tranistitial of CRD Reporc No. 23,6 Operational Safety Evaluation of ETSw Complex.

3.0.63 Transmittal. of Daca Acquisztzon L2st, $1 C 6=09 \%$

(CRD) arid Devailed Summery ICC- $2 \%$ O

3-12=63 Facisty Móificauion

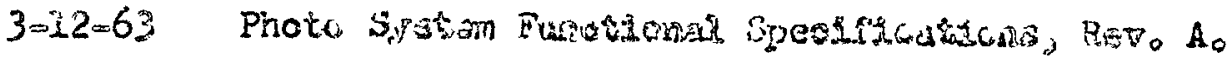

3-29-6\% Transmital of Comments on Functional Specifica tions for "actiliby Concrois System。

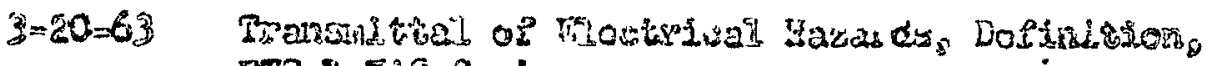

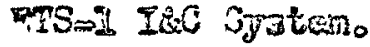

3020-063 Transmittal of Signal Cordisioning Requitrements for all Systerns, ICCO222A.

3-20063 Agreenents on the Facility Systems.

3-2.263 Transmittal of Photo Canera Fiolds of View \& EIS-1 Photo Camera Buniser Positions。 


\section{LETTERS}

CORRESPONDENCE TO EDGERTON GERMENSHAUSEN \& GRIER, INC.

\begin{tabular}{|c|c|c|}
\hline LETTER NO. & DATE & SUBJECT \\
\hline Lo213 & $3=22-63$ & Transmittal of Results of TV Station Field Survey. \\
\hline 10129 & $3-26-63$ & $\begin{array}{l}\text { Transmittal of CRD Report } 2316 \text {, Operational } \\
\text { Safety Evaluation of ETS. I Complex. }\end{array}$ \\
\hline 20124 & $3-27-63$ & $\begin{array}{l}\text { Transmitici of Comments on Facility hodification } \\
\text { Criteria, iV \& Photo Systems and Meteorological } \\
\text { Tower. }\end{array}$ \\
\hline L0126 & $3-29-63$ & $\begin{array}{l}\text { Intitial Tech. Evaluations of the Proposals } \\
\text { Submitted to EG\&a }\end{array}$ \\
\hline LoL22 & $4=1=63$ & $\begin{array}{l}\text { Transmittal of Aerojet Dogo } 084959 \text { Test Stand } \\
\text { Adepter ard Thrust Structure Irterface Control. }\end{array}$ \\
\hline LOI30 & $\mu_{i}=1,=63$ & 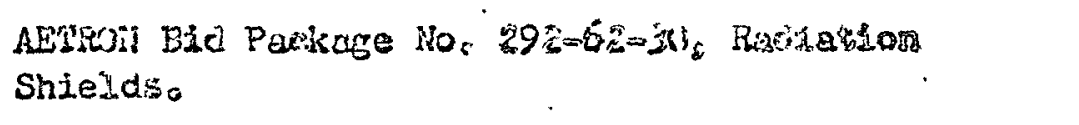 \\
\hline 20326 & $402=63$ & $\begin{array}{l}\text { Trarsmittal of Recomended Console layout. } \\
\text { Drakirss \& Tabulations. }\end{array}$ \\
\hline LOI2\% & $4-25$ & Transmitial of Photo Canera Stration Ledationso \\
\hline LOL 3 & $4,-5=63$ & Functional Speco Analog Recording Sjstemo \\
\hline$[.0233$ & $4=8-63$ & Functional Speco for TC\&P Sepo \\
\hline $\mathrm{LOB} 34$ & $4=8-63$ & Functonal Requirements Digita. Dati Systemo \\
\hline LO132 & $4-9=63$ & Functional Spec。Events Recoräirg Systima \\
\hline 20239 & $4=9=63$ & Facility Nodifleations. \\
\hline LOL39 & $4, \infty=63$ & Ergire Irstallation Venicle Assy。 Drgo No。 073915。 \\
\hline $\operatorname{Lo} 36$ & $4-10-63$ & $\begin{array}{l}\text { REON Dygo 091035, Composite Flow Dlagram, Procesa } \\
\text { Systomso }\end{array}$ \\
\hline 20138 & $4=12=63$ & Speciai/Standara Functional Fanily Treto \\
\hline 2024] & $4-12=63$ & ICC-100, Facility Graphic Display Paral。 \\
\hline $\mathrm{LO} 240$ & $4=15=63$ & Furictiona Specso Safeity System Rov. A. \\
\hline LOLLS & $4-15-63$ & Revision A o Functional Spec.s Tumarg System。 \\
\hline
\end{tabular}




\begin{tabular}{|c|c|c|}
\hline LETTHR NOO & DATES & SUBJECT \\
\hline 10144 & $4-18-63$ & Televiaion Systew Functional Specifications, Rev. A. \\
\hline I0149 & $4-22-63$ & Addendun iNo. 6 - Transinittal of \\
\hline$I 0146$ & $4-22-63$ & Grounding Standords, Electrical Design Standards \\
\hline I,OI52 & $4-22-63$ & $\begin{array}{l}\text { Detailed Prel. Dag Dwes R. F. Co.unnication, } \\
\text { Sys for ETS-1 }\end{array}$ \\
\hline 10143 & $4-23-63$ & Reconnendcd Locations for T.V. Stations Nunbers $9,10 \& 1$ \\
\hline$I, 0150$ & $4-23-63$ & $\begin{array}{l}\text { Detailed Prel. Dsg. Drg - Control Monitor Cirauits, } \\
\text { Photo System for BtS-I }\end{array}$ \\
\hline IOI5I & $4-23-63$ & Functional Specs. Notes - Rev. A. \\
\hline 10153 & $4-23.063$ & $\begin{array}{l}\text { Detailed Prel. Dosign Dibs, Comunications System for } \\
\text { DIS-1 }\end{array}$ \\
\hline 10159 & 4.23 .63 & 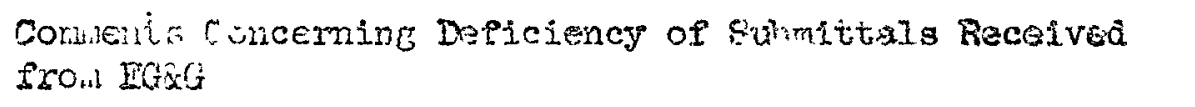 \\
\hline 10154 & 4.25 .63 & $\begin{array}{l}\text { Televiszor and Hoin Systels, Facility Munteication. } \\
\text { Griteria, hev. A. }\end{array}$ \\
\hline 10156 & $4 \times 25-63$ & 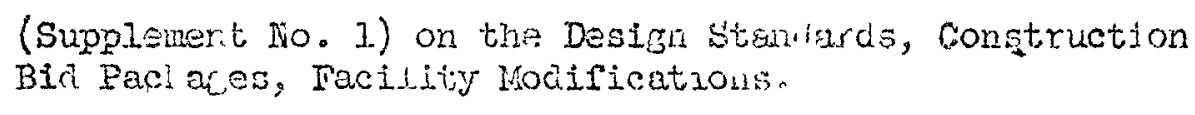 \\
\hline 10157 & $4-25-63$ & 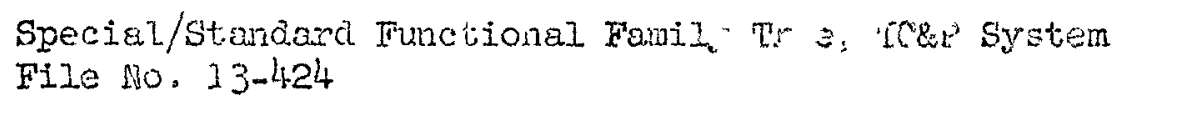 \\
\hline 10160 & $4-20-53$ & Action Itcm 9.1 - Sichal Interfoce for RLd Syotsu \\
\hline $\mathrm{IO}_{3}$ & $4-30.55$ & 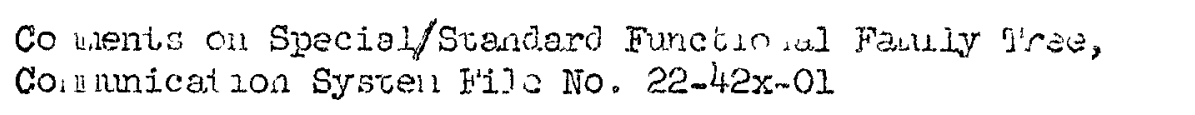 \\
\hline 10160 & $5-2.63$ & $\begin{array}{l}\text { TH. Ling Systan - Connents Reserved Until. Creater } \\
\text { Design Det ail Conpleted }\end{array}$ \\
\hline 20167 & $5=2-03$ & Signal Corajtioning System - Same tw Above \\
\hline 10170 & $5-2-63$ & $\begin{array}{l}\text { Recondended Clianges to Iuprove Accuracy of Digital } \\
\text { Dat,a Systemo }\end{array}$ \\
\hline 10163 & $5.7 \times 03$ & $\begin{array}{l}\text { Ti ine Sycreil - Colleits on. File N } 23-25 \mathrm{X} \text { and } \\
23-35 \mathrm{X}\end{array}$ \\
\hline
\end{tabular}


TETITERS

CORRESPONDEUTCE TO EDGERTON, GERMESHAUSEN \&: GRIER, TNCL,

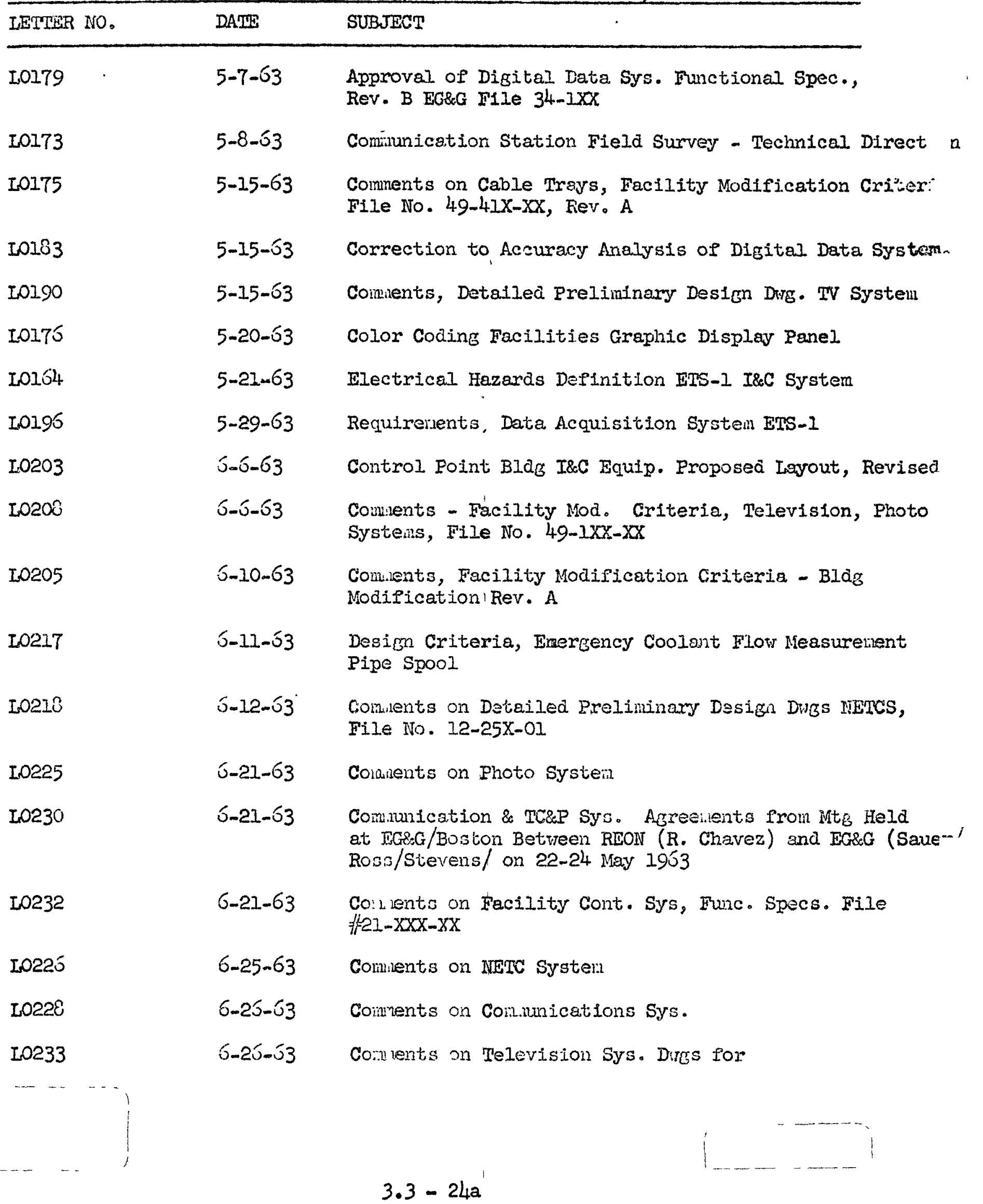


CORRESPONDENCE TO EDGRRTON, GERMESHAUSEN \& GRTER, IMT.

\begin{tabular}{|c|c|c|}
\hline LETTER NO. & DATE & SUBJECT \\
\hline L.0235 & $7-3-63$ & $\begin{array}{l}\text { Approval of Facility Moä. Crit., Cable Trays, Fice } \\
\text { No. } 49.41 \mathrm{x}-31 \text {, Rev. B, Dtd } 10 \text { May } 1963\end{array}$ \\
\hline 1,0229 & $7-8-63$ & Photo Sys Dirgs, Counents \\
\hline 10240 & $7-11-63$ & Approval of Photo Sys Dircs \\
\hline I.0237 & $7-15-63$ & $\begin{array}{l}\text { Comuents on Fac. Mod. Crit. Test Stand Temunal Boxes, } \\
\text { File No. 49-7XX-XX, Rev. A \& Planuing Inaex EIS-l Des. } \\
\text { Data File, Fac. Mod, File No. } 49-X X X-X X \text { Rev. B }\end{array}$ \\
\hline 20254 & $8 . .5-63$ & Duct \& Suield Paraneters to be Displayed \\
\hline 20283 & $8 \cdots .5-63$ & DISw 1 Television Camera Motion Sys KFP No. 1183-10B \\
\hline 10285 & $8-1.6-63$ & ETS-1 Control Room Consolos Das. Ditg \\
\hline 10275 & $3-19-63$ & Transaucer Iist for 3.ray Vent VaIve Sys ETS-I \\
\hline L0288 & $8-20.63$ & $\begin{array}{l}\text { Use of Relays in EIS-1 Control Muadtor Cuxcuits } \\
\text { Photo Systom. }\end{array}$ \\
\hline I0282 & 8.28 .63 & Comnents, EG\&G Draft, Room Mranual \\
\hline 10290 & $9.4-63$ & ETS. I Data Acq. Sys. Digo Data Procussor Heq"mt Cors \\
\hline $\mathrm{LO}_{0} \mathrm{~g}_{4}$ & $9-4-63$ & FIS. Fac Cont Sys-Solgnoid Valve Box Drawings \\
\hline 1.0297 & $9.023-63$ & Fac. Cont. Systems, Adaitions, Cornetioss \& Dulotions \\
\hline 10319 & $9=26-63$ & 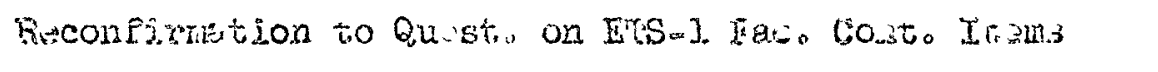 \\
\hline 10321 & $9=20.63$ & 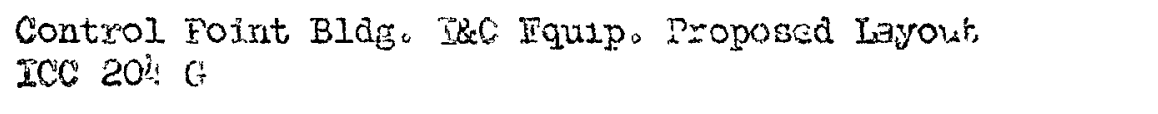 \\
\hline 10324 & $20.15 \div 63$ & Mimutes of Dsn Nitz Dig Data Sys Spac. \\
\hline
\end{tabular}


ADDENDA TO ETSOI IRC DESION CRITERTA

SUBMITTED TO SNPOC

Addendum No. Dato Content

3

4

5

6

7

8
1 June 1963

5 Narch 1963

1 June 1963

I Juno 1963

19 July 1963

1 June 1963
Dolets electrical poyer, tunnel modification, and fire protoction from Iac dealgn critoria.

A. Ammends Facility IzoC Channel List, Volo IVo

B. Ammends Criteria Vol. Is Appendix 4.2 (transducers)。

C. Ammends Criteria Vol. II, 23 revised interface drating s。

Providea

A. Gaseous hydrogen system.

B. Hyörogen venting.

C. Complote block valve design.

D. $\mathrm{LH}_{\mathrm{g}}$ bleed valvo。

E. Rovised tomperature monitor.

F. Completes information on temperature and pressure inulcaison.

Q. Add to Criteria Vol. IV data aquisition IIst and Facility Channel 1ist.

Amonds design of timing systom。

Includes revisions and delotions required in the EC\&a preliminary design package for completion of design Phase $I_{0}$

Revised technical data (OPDP November 1969) Duct and Shield Monitor Critoria. 
INIILSS AND TWX

Coxreopoxdence Iron EG \& C

\begin{tabular}{|c|c|c|c|}
\hline TWX 10. & IEETIAR HO. & DATS & SUBJECT \\
\hline & $\mathbf{x}$ & $12-19$ & 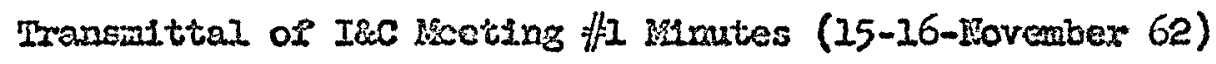 \\
\hline \multirow[t]{4}{*}{3091} & & $12-6$ & Agenda for 11,12 - Decerber leeting \\
\hline & $x$ & $* 12-14$ & Subrisston of Plans and Schedules \\
\hline & $\mathbf{x}$ & $12-14$ & Trananittal of Ifoeting fle Elinateg (11, 22 Dec.) \\
\hline & $\mathbf{x}$ & $1-2$ & Tranasittal of Meting $/ 13$ Mimutes \\
\hline 3129 & & 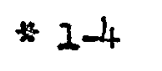 & TDS-5.1 Leoting 3 not Accepted by EG\&G \\
\hline \multirow[t]{6}{*}{299} & & $1-8$ & File Data Syatem \\
\hline & $x$ & $* 1-14$ & Wonthiy Status Report, 31 Decomber 1962 \\
\hline & $\mathbf{x}$ & $* 1-14$ & RFQ DLEital Syoten 1183-3P \\
\hline & $x$ & $1-16$ & Submittal Preliminal Desisn TV System \\
\hline & $\mathbf{x}$ & $1-17$ & Subait Functional Spec Events \\
\hline & $\mathbf{x}$ & $1-18$ & Subint Funztional spec Froto \\
\hline \multirow[t]{7}{*}{333} & & $1-19$ & TLS 5.2 Chonges \\
\hline & $\mathbf{x}$ & $1-21$ & Submit El. Power Syetem Functional Spec \\
\hline & $\dot{x}$ & $1-21$ & Subait IUWh Spec \\
\hline & $x$ & $1-22$ & Subnit Functional spee Anglog Pecording \\
\hline & $\mathbf{x}$ & $1-24$ & Transartital Bifoutes I\&C Ireting t5 \\
\hline & $x$ & $1-24$ & Tranarittal ininutes Ire riecting \\
\hline & $\mathbf{x}$ & $1-25$ & Document Distribution \\
\hline \multirow[t]{7}{*}{ IA-037 } & & $1-25$ & RePcrence THX 1010, Technical Heeting \\
\hline & $\mathbf{x}$ & $1-29$ & Subait Digital Syaten Functional. Spec \\
\hline & $\mathbf{x}$ & $1-29$ & Submit Data Acq. Syaten Functional Spec \\
\hline & $\mathbf{x}$ & $1-30$ & Transulttal Functional Spec Cormuntestions \\
\hline & $x$ & $1-31$ & Transmittel. Funcioional Spec Timing System \\
\hline & $\mathbf{x}$ & $1-31$. & Transmittal ILloutes I\&C Meeting \#3 revised \\
\hline & $\mathbf{x}$ & $2-1$ & Subaittal Iunctional spec Slgnal Conaitioning \\
\hline \multirow[t]{2}{*}{3220} & & $2-4$ & Delay Subaisaton of spec on Facility Control \\
\hline & $x$ & $2-4$ & Mranguttal of IEC Hectins inuber 6 lunutes \\
\hline
\end{tabular}

$$
3.3-27 a
$$


Comespondonce from EG \& G

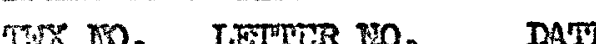

\begin{tabular}{|c|c|c|c|}
\hline & $\mathbf{x}$ & $2-5$ & Rranamittal TV syater Functional spec (Rev A) \\
\hline & $x$ & $2-5$ & Transmit TV Systen Functional Spec., Revised \\
\hline & $\mathbf{x}$ & $2-5$ & Foraat for Evaluation Digital Systen Prop. \\
\hline & $\mathbf{x}$ & $2-6$ & Trancmittal of Repros D/A System \\
\hline \multirow[t]{6}{*}{3239} & & $2-7$ & TV Discussion at 2-11-63 feoting \\
\hline & $\mathbf{x}$ & $2-11$ & Monthly Status 1-31. \\
\hline & $\mathbf{x}$ & $2-11$ & I\&C System Rev1ew end Appxove Schedules \\
\hline & $\boldsymbol{x}$ & $2-11$ & Tranaraftal Facllity Kods: MHEC, Cable Mrays, Bldg. Mod \\
\hline & $\mathbf{x}$ & $2-15$ & Trancmittai of I\&E Maeting if 7 \\
\hline & $\mathbf{x}$ & $* 2-15$ & Subnit KFP 1283-3B Digital Data Systen \\
\hline 3271 & & $2-18$ & Reliability afd Q.C. \\
\hline 5503 & & $2-25$ & $C$ ble Requiresents $\mathrm{BC}$ and REC \\
\hline 3000 & & $2-25$ & Digital Data Dasign R vicw liecting \\
\hline \multirow[t]{2}{*}{3303} & & $2-26$ & Confirm Blanchard to SACIO \\
\hline & $\mathbf{x}$ & $2-27$ & Transmittal Facility Control Functional Spec \\
\hline \multirow[t]{2}{*}{3371} & & $2-27$ & As-Built storage Vessel Dramings \\
\hline & $\mathbf{x}$ & $2-28$ & Transmittal Fuoto System Functional Spec Revised \\
\hline \multirow[t]{9}{*}{3315} & & $2-28$ & IV Cameras 9, 10, 11 \\
\hline & $\mathbf{x}$ & $3-1$ & Trans. Facility Mode T.V. Fhoto and MIST Towet Funct Specs \\
\hline & $x$ & $3-1$ & Transmittal Safoty System Functional spec \\
\hline & $\mathbf{x}$ & $* 3-6$ & Subraittal I Ilne Flectrical \\
\hline & $\mathbf{x}$ & $3-7$ & Transmittal Anelog Irunctional Spec (Fer A) \\
\hline & $x$ & $3-7$ & Transmittal Erents Funational Spec \\
\hline & $\mathbf{x}$ & $3-8$ & Transmittal Comulcation Syeten Functional Spec (Rev A \\
\hline & $x$ & $3-8$ & Trangmittal Digital Data Functional Spec (Rer A) \\
\hline & $\mathbf{x}$ & $3-8$ & Transaittal IETCS Functional Spec (Rev A) \\
\hline \multirow[t]{3}{*}{3351} & & $3-11$ & Schedule Subralttal $R$ and Q.C. Plan \\
\hline & $\mathbf{x}$ & $3-12$ & Transmittal Feb Status Report \\
\hline & $\mathbf{x}$ & $3-14$ & $\begin{array}{l}\text { Trensmittal R\&Q Assurance Flan, QC Mamual, Rel. } \\
\text { Design Sta. }\end{array}$ \\
\hline
\end{tabular}

$$
3.3-28 a
$$


Correspondence from EG \& $G$

\begin{tabular}{|c|c|c|c|}
\hline TWX INo. & IETIER NO. & DATE & SUBTECI \\
\hline & $\mathbf{x}$ & $3-20$ & Transmittal Safety System Functional Spec (Rev A) \\
\hline & $x$ & $3-20$ & Transmittal Timing System runctional spec Revised \\
\hline & $x$ & $3-21$ & Mransmittal Photo System Stds/Spec FFT \\
\hline & $\cdot x$ & $3-22$ & Transmittal TCis Functional Spec \\
\hline & $x$ & $3-22$ & $\begin{array}{l}\text { Mransmittal Facility Mod Criteria: Terminal Boxes } \\
\text { Ceneral Fin Criteria Rev A, Intex and } \mathfrak{T}-\mathrm{C} \text { Rev A, } \\
\text { Dosign Stds }\end{array}$ \\
\hline & $x$ & $3-25$ & Transmittal Fl Design Grounding \\
\hline \multirow[t]{11}{*}{3416} & & $3-28$ & IDS, Phase I Design, Scope of Work statement \\
\hline & $x$ & $4-3$ & Transmittal Signal Cond s/s FriT \\
\hline & $x$ & $4-3$ & Iransmittal Photo Detail Prelim Design Dug CaM Circults \\
\hline & $x$ & $4-4$ & Transmittal Com System Detail Design Prelim Dwgs \\
\hline & $\mathbf{x}$ & $4-5$ & Pransmittal Facillty Mod Criteria (Rev A) TV and Photo \\
\hline & $\mathbf{x}$ & $4-15$ & Transmitcal Rr Syscem Detail Prelin Design Drgr \\
\hline & $x$ & $4-15$ & Transmittal Timing System Detail Prelim Design Drgs \\
\hline & $\mathrm{x}$ & $4-15$ & Tranamittal icos S/S FHP \\
\hline & $\mathbf{x}$ & $4-15$ & Transmittal Timing System S/S FFI \\
\hline & $\mathbf{x}$ & $4-15$ & Transmittal Cormunications system s/s IFT \\
\hline & $\mathbf{x}$ & $4-15$ & Iransmittal TV Detailed Preliminary Design \\
\hline 3500 & & $4-15$ & Adaltional Cost IV stat. 12 \\
\hline 3504 & & $4-16$ & Correspondence Distribution \\
\hline Is987 & & $4-18$ & ECRC Submittal File Wumbers \\
\hline 3526 & & $4-18$ & Camera Efiective Aperture, Periscope vs. Mirrors \\
\hline \multirow[t]{2}{*}{3434} & & $4-2$ & $400 \mathrm{cps}$ Pover Requirement \\
\hline & $x$ & $4-11$ & Transmittal Monthly Status March \\
\hline \multirow[t]{3}{*}{3531} & & $4-19$ & Cabling Conform to INEC \\
\hline & $x$ & $4-24$ & Recomend Alt. Design Mins. System \\
\hline & $x$ & $4-25$ & Transmittal Facility hod Criteria, Cable Trays (Rev A) \\
\hline 3536 & & $4 \cdot-25$ & Photo Iens App., Periscope vs. Mirrors \\
\hline $\begin{array}{l}702-248- \\
7018\end{array}$ & & $4-30$ & $\begin{array}{l}\text { Confirm Agreements Made at IV } \\
\text { (1) Remove TV Control ISE } \\
\text { (2) Delete Remote Control Door/Gate ISE }\end{array}$ \\
\hline 3582 & & $4-30$ & Comment on InEns system \\
\hline
\end{tabular}


IEMWITRS AIVD TWX

Correspondence from raga

\begin{tabular}{|c|c|c|c|}
\hline max 210 & IEIIHER MO。 & DATP & SUBJIECT \\
\hline I22 & & $4-30$ & Request Envlronmental Data Oxygen and Hydrogen Sample \\
\hline 3583 & & $5-1$ & S/S FFT Data Avail. 6-10-63 \\
\hline \multirow[t]{2}{*}{231} & & $5-1$ & Added Cost Revise Facllity Mod Title Block \\
\hline & $x$ & $5-2$ & Transmittal TCaP Detail Prelim Design \\
\hline \multirow[t]{2}{*}{3587} & & $5-2$ & DDS Scope of Work \\
\hline & $\mathrm{x}$ & $5-3$ & REON Corment Facility Mod and CBP Design Stds \\
\hline \multirow[t]{2}{*}{3596} & & $5-6$ & Photo System Agreements CaM Circuits \\
\hline & $\mathbf{x}$ & $5-6$ & Transmittal IEETCS Detail Prelin Design Drgs \\
\hline 3591 & & $5-6$ & Ens-I Photo-Periscope vs. Mirrors \\
\hline 546 & & $5-6$ & Facility kod Criteria, Cable Trays \\
\hline$I+1$ & & $5-6$ & TV and Photo Bunk Facility Mod Design Review \\
\hline 3595 & & $5-6$ & Agenda for QG Meeting 5-9-63 \\
\hline 3597 & & $5-6$ & Revision to IWX 3587 \\
\hline 3602 & & $5-6$ & Pover System and Cable Trench Requirements \\
\hline \multirow[t]{3}{*}{ I.52 } & & $5-7$ & Schedule Facility Mod Review \\
\hline & $\mathbf{x}$ & $5-7$ & REON Corment Facility Mod, Building Mods \\
\hline & $x$ & $5-7$ & Transmittal Minutes Irc Meeting 8 \\
\hline 3611 & & $5-7$ & Agenda for Orientation at EC\&C $5-13-63$ \\
\hline 3610 & & $5-7$ & Reliabllity Photo System DesIgn \\
\hline 3617 & & $5-8$ & I\&C Power for EIS-2 \\
\hline 4001 & & $5-9$ & Comment on Exse Analog Recording \\
\hline L70 & & $5-10$ & EGed Requirement fox Fac ility Mod Met Tower \\
\hline 3626 & & $5-10$ & Update Operational Requirement Photo System. \\
\hline \multirow[t]{6}{*}{ I3I } & & $5-13$ & Mitle Block Faclitity Mods \\
\hline & $\mathbf{x}$ & $5-9$ & Response to REON Corment Events Recording \\
\hline & $x$ & $5-14$ & Mransmittal Preliminary Iist of Drgs \\
\hline & $\mathbf{x}$ & $5-14$ & Transmittal Facility Mod Criteria TV and Photo \\
\hline & $\mathbf{x}$ & $5-14$ & Minutes of Controllex Design Review \\
\hline & $x$ & $5-14$ & ErIS-2 Cable Requirements \\
\hline 3642 & & $5-15$ & Breakers, Power System \\
\hline
\end{tabular}


Correspondence from EGSG

THYX NO, LETTER NO, OO DATE

$\mathbf{x}$

$617-262=$ 9357

$L=100$

$617-202=$

937

4016

4012

$x$

4016

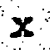

$x$

$x$

$x$

$x$

$\mathbf{x}$

$\mathrm{x}$

$x$

$x$

$5-20$
$x \quad 5-21$

$x$

- 5-22

* 5-23

$5-24$

$5-24$

* 5-24

5-24

$5-27$

5-27

$5-27$

5-27

$5-28$

I- 127

4021

$\operatorname{In} 130$

4019

4023
5-28

$5-29$

$5-29$

* 5-31

*6. 6

$5-31$

$5-31$

6- 4
Transmittal Facility Mod Test Stand Terminal Boxeg (Rev A)

SUBJECT
DDS Super Como Technique

Transmittal, Block Diagram

Transmitta Safety System Drawings, Communication. Timing and Photo

Transmittal Honthly Status April 1963

Transmittal Facility Mod Cable Trays (Rev B)

Sito Survey, TV Canera Stations

Transmittal Hinutes of Orientation Keeting at EG\&d $5-13-63$

Cable Tray Facility Mod Design Review Schedule

Transmittal of Photo and Communications Drawings

Action Items Photo Bunlear Facility Mods

ROM Costs TV Station 12

Radiatión Design Critoria IV Stations $9,10,11$ and 12

Transmittal DDS (I) Scope of Work Phase I (c) Function Spece (Rev C)

IV Station 12 Cost Estimate

Elect. Hazards Dafinition

Transmittal Drawings, NETC Photo, Communications TV Overaly Systora

Transmittal Drawing List

Transmittal Facility Mods Index, Terminal Boxes (Rev A)

Trensmittal Faclitty Control Functlonal Spec (Rov A)

Survey of Equipment for Deta $\mathrm{P}_{\text {rocessor }}$ and Checkout Fac.

Fac lod Design Rav Cable Trays and Terminal Boxes

Transmit tal Drawing and Document $\mathrm{L} 1 \mathrm{st}$ (Rev $\mathrm{B}$ )

TV Camora Locations

Excltat ion Power supply

Transmittal, Equipment Cost Estimato for SP Phaso

Safety System Submittal

DDS Agreemants Confirmsd

Relocate IV Station 3 
Carrespondenco from EQSd

TWX NO, LETTER NO.

Lo130

4023

4027

4030

I-173

$1+176$

$x$

$4-176$

L-177

L- $] 78$

4036

4036

$x$
$x$

X

$x^{2}$

$x$

$x$

$x$

स 6-8

60010

6-10

*6-10

$6-11$

6-13

$6-13$

60013

$6-13$

* 6-13

6-13

$6-14$

$6-17$

* 6019

$6-20$

6-21

$6-21$

L-2I]

$6-21$

$\operatorname{L}-210$

Ise211

$\operatorname{In} 213$

4050

3710

4057

4052
* $6-21$

6-21

* 6-21

* 6-25

* 6-25

6-26

6-26
Safety System Block Diagram

Relocation of IV Camera Station 3

Scope of Work and Costs CY 64

Phase II Cost Estinates

Transmittal S/S FFT Analog and Event Rocord

REON Lotter 741:0159, 4-23-63

Transmittal RFP 1183-10B

Safoty System TD

Fac. Mod, TV and Photo

Transmittal FG\&G DRM

Facility Mod Po Jlizol5

ETS-1/2 Power Requiroments

Facility Mod Bid Packago

Control Roon Layout, Design Reviaw Meoting

Transmittal Minutes, IRe Meeting 10

Acknowledge Receipt of $2741: 0205$

Facility Ifod Bld Packages

Correct TWX L-173

IV Camara Motion Systom

Confirm Design Package Submittal

I $C$ C Correspondenco

Transmittal Dosign Package

Transmittal Status May 1963

Facility Mod Meeting 6-21-63

Rack Relocation, Facillty Mod Schedulo

Package lieviow

Relocation Racks, Cable and Equipment

SNPO-C Meeting

EClda Rap at Hetings

Reliability and $Q_{0} C$.

Prelin. Design Package Submittal

Prelimo Design Package Suhmittal 


\section{LETTERS AND THX}

Correspondence from EGed

TWX NO O IETTER NO.

\section{9}

95

ko61
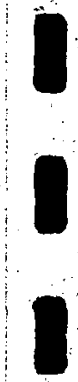

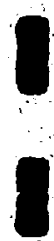

3720

$-268$

4091

$\mathrm{I}-298$

4703

$x$

4II2

4112

4716

4713

4319

$x$

+7019

* 7-23

$7-25$

* 7-29

$7-31$

$7-31$

$8-1$

8-1

$48-2$

8.6

$x$

8.6

- 8-7

$x$

$x$

\section{$-1$}

.

.

.

\section{.}

\section{1.}

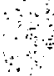

a


Correspondence from EGRG

TWX NO IETTER NO DATE

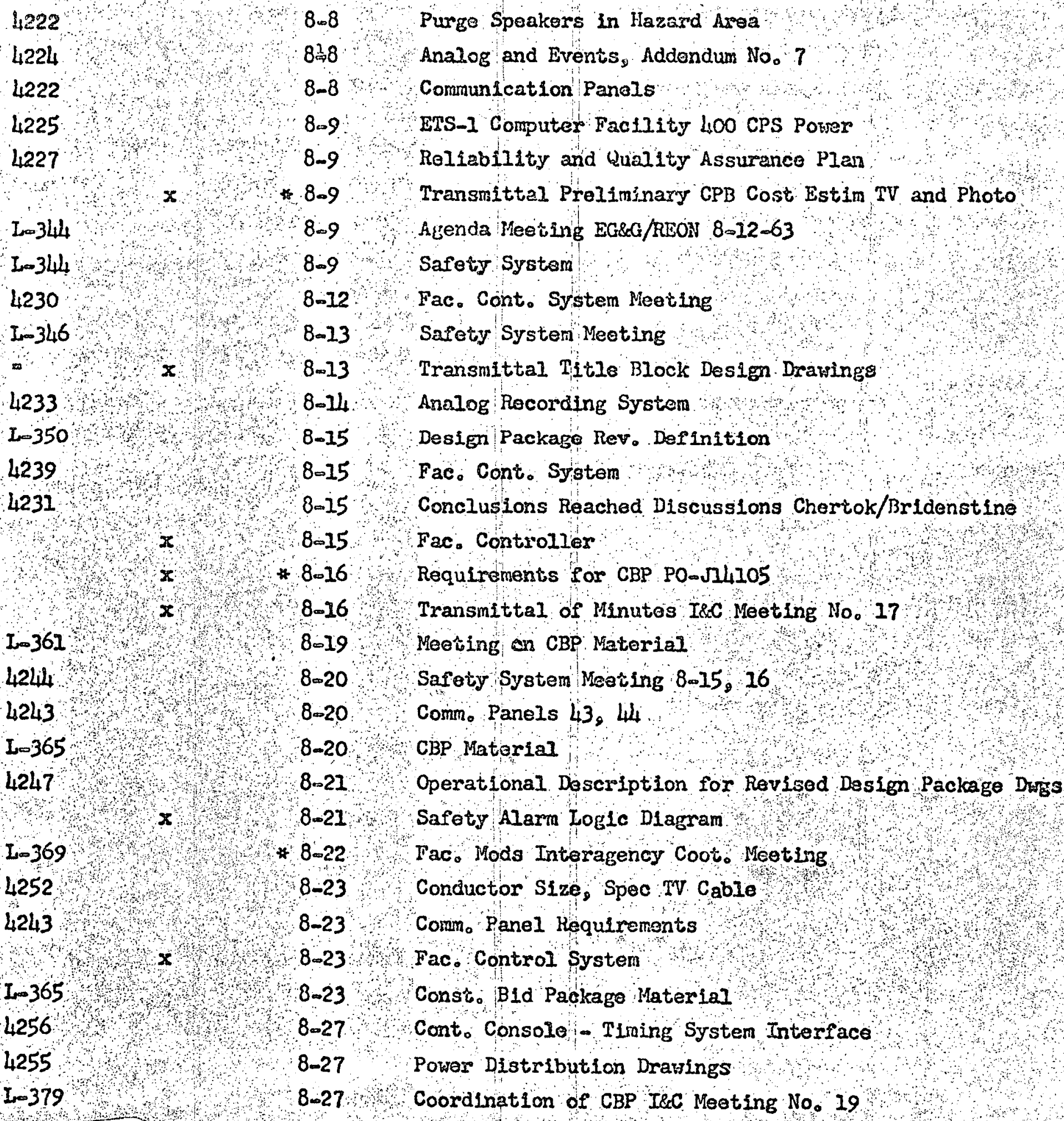




\section{IETTERS AND TWX}

Correspondenco from $B G \& G$

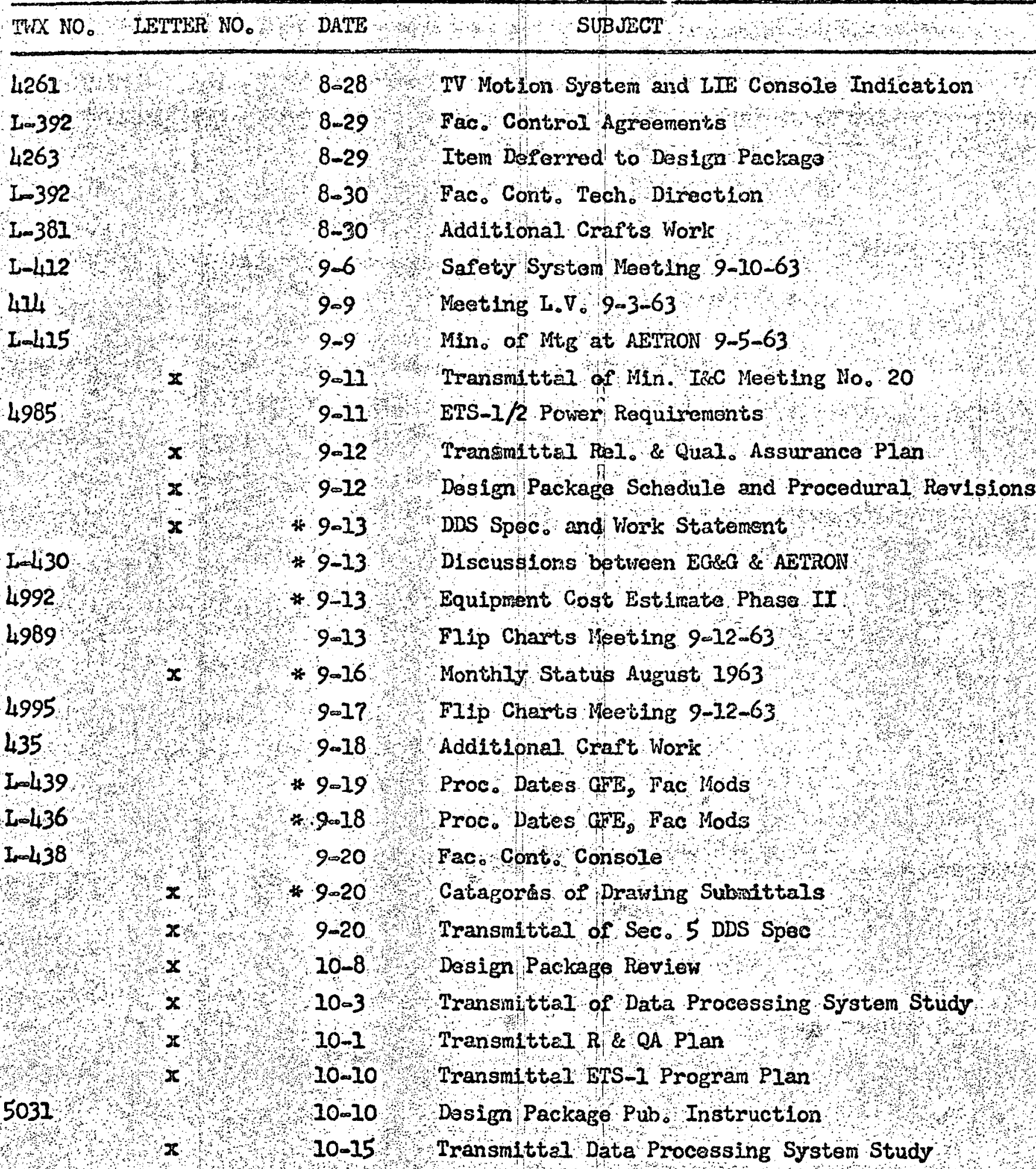




\section{IETTERS AND THX}

CORREGYONDISUCE TRSM SNPO-C

TWX NO.

LETTER NO.

DATE

SUBJECT

$\mathbf{x}$

10-9-62

SM 5

$x$

$\mathrm{BT}$

$S M=021$

$\mathbf{x}$

$S M=040$

$\mathbf{x}$

$x$

$\mathrm{SN}=114$

Sif -011

$S M_{\infty} 01 ?$

$S M-033$

SH -045

C919R

$x$

$x$

$x$

$x$
$10-24-62$

$21-15-62$

$11-27-62$

$12-21-62$

$12-28-62$

$12-28-62$

$12-31-62$

$12-31-62$

$1-4-63$

$1-8-63$

$1-9-63$

$1-10-63$

$1-14-63$

$1-17-63$

$2-18-63$

$1-13 \times 63$

$1-21-63$

$1-21-63$
$1-18-63$
Submit recommended safery warning system

Concrol Room Layouts

Átiendance at BGRG Meetiüb

I\&C System Completion date

Request Repro. of criteria and OPDP drawings

TD procedure-flag cost changes

I\&C systom completion dates

EARG statement of work

Transmittal work statement I\&C system

Correct; oscillographs, patching, computer requirements, 2Ms events, intercom, meeting minutes, SiNPO-C information, submittals, $R_{0} F_{0}$ proposals, and schedule.

Transmittal interphone requirenents to EG\&G

Correct TWX SM-274

Request for $R F$ system clarification and $A D C$ No proposal

Procedures and schedules

hequest ERRG attend PERT neeting

Hinutes of I\&C Neeting No. 2

Copcus with minutes IsC Neeting 3

Concur with minutes I\&C Meeting 1

REON required approval timo

Confirm telecon $1-18-63$ transmit to EG\&G Items $A \& B$ of REON TIX 617, $1-15-63$ 


TWX NO -3 IETTER NO , DATE

$\mathrm{SM}-0 \mathrm{O} 4$

$1-27-63$

$x$

$S M-080$

SM -079

033

034

$R=0115452$

SM 055

$\mathrm{R}-1220322$

2

$R=181856 \mathrm{z}$

$\mathrm{R}-181908 \mathrm{Z}$

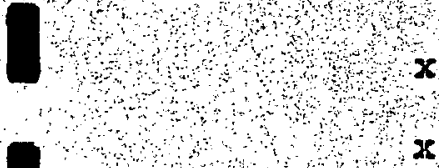

$20-418032$

$R-1317082$

$R-1817562$ $x$

$\mathrm{x}$

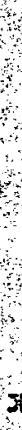

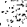

$-12-63$

$2-12-63$

$2-13-63$

$2-18-63$

$2-18-63$

$\mathrm{x}$

$x$

$x$

$x$

$x$

$\mathbf{x}$

$3-15-63$

$3-19-63$

$3-4-63$

$3-8-63$

$3-13-63$
RP channeló operation safety

REON required approval time

AETRON Drauing EIS-1 Complex

Deléte display panel on LIE

Consider facility $\mathrm{Hod}$ as TD

Comment on TV 15 T.D. Take Action.

T.D. procedures

Facility nodificatlons and facility control Consider comments on photo system as $\mathrm{T}_{\text {. }} \mathrm{D}_{0}$

TD procedures and EG\&G work statement

lonthly status report

Q.C. and Ro

Revised EG\&G work statement

ITE\& month y status report

SNPO approve control room layout

$2-18-63$, N purge of instrument boxes

$2-19-63$, w Gi hazardo classification

ETS-1 El. hazards definitions

Criteria Addendum 3

$3-8-63$ ? Iransmitta 1 Addendum 3

$3-12-63$, N 2 purge instrument boxes

Ty station $9,10,11$ and duct

Miss-sent repor's of analog functional spes.

Request RFC complete flow dia. 


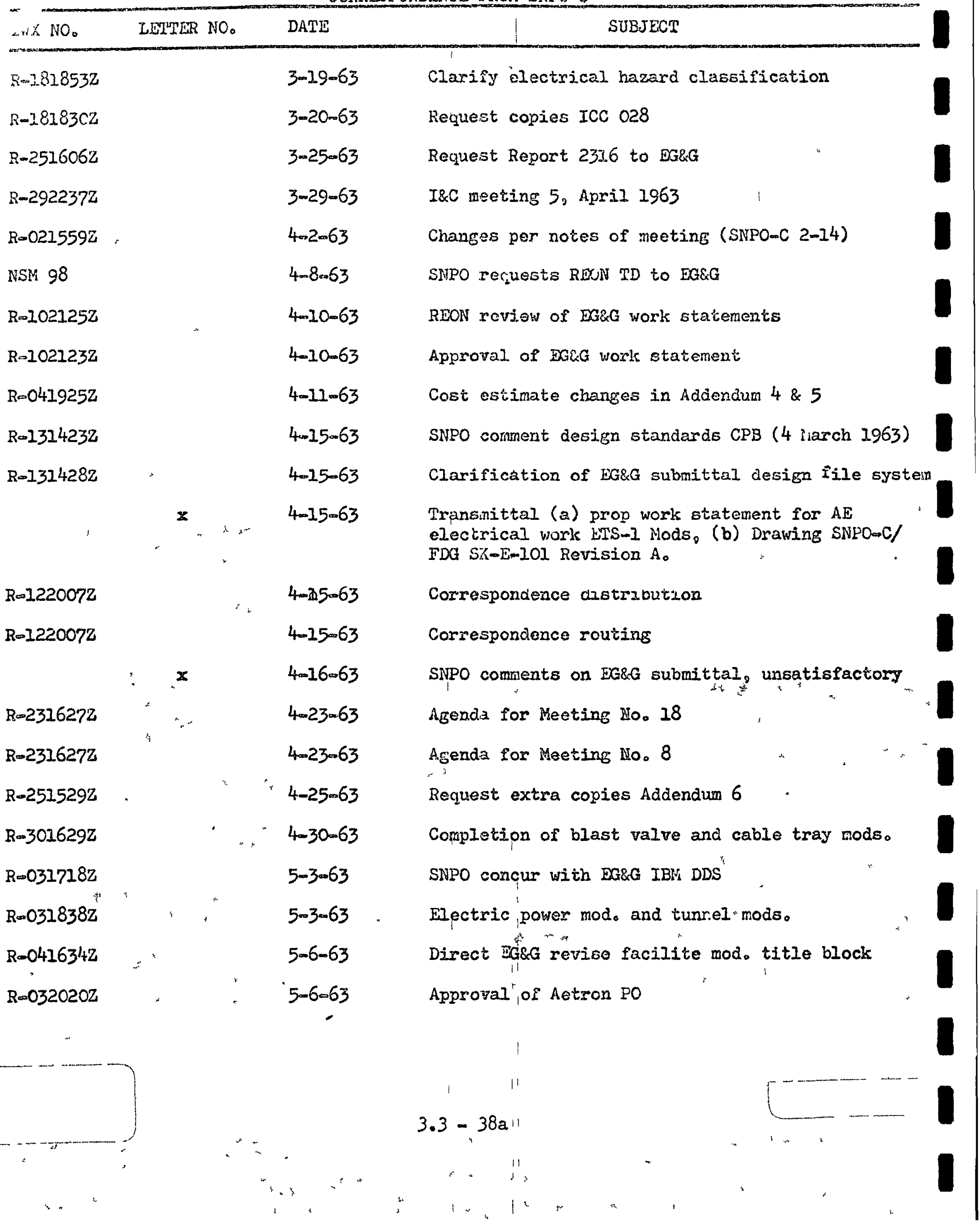


IETIERS AND TWX:S

CORRESPONDENGS FRON SNPO-C

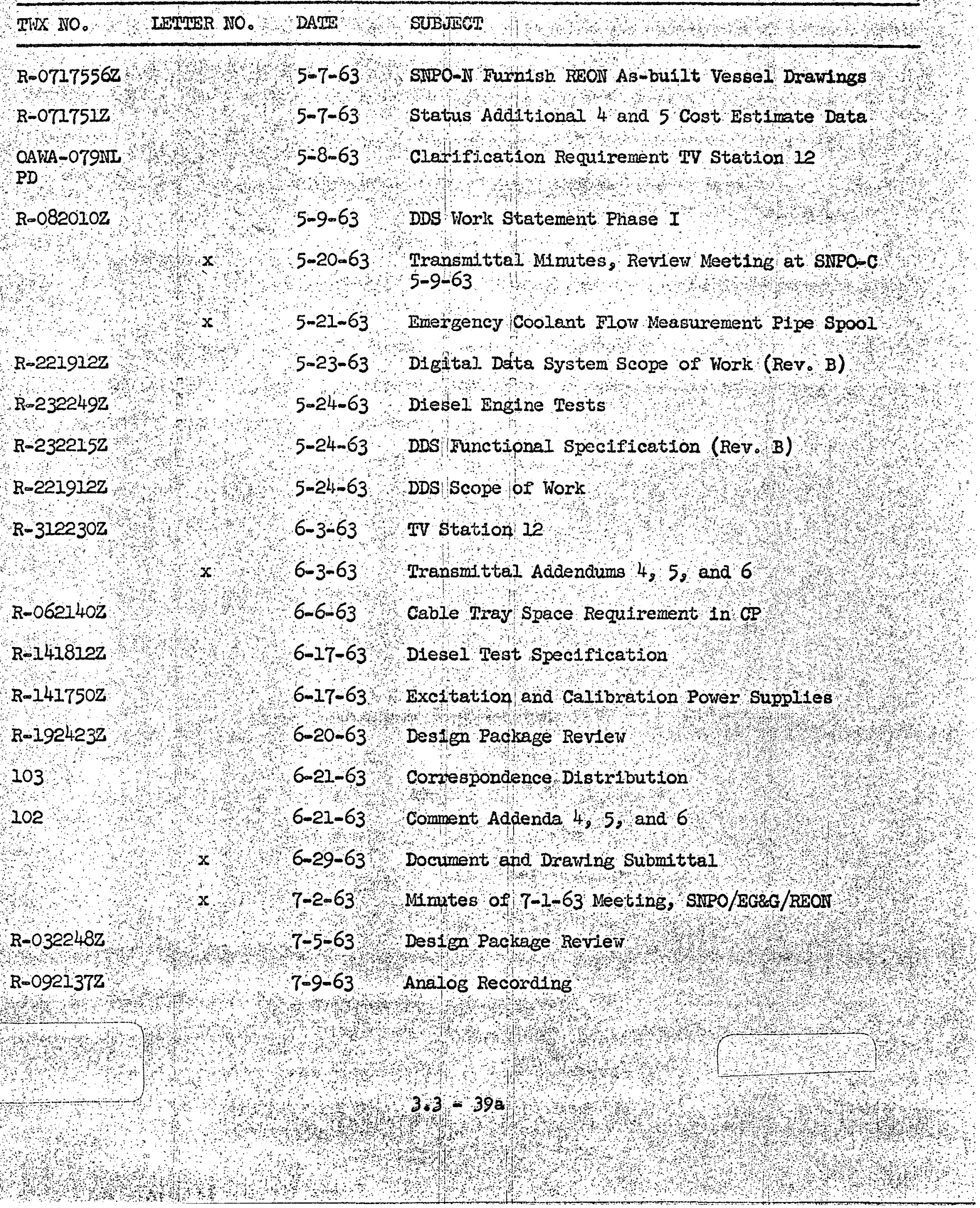


IEIYUERS AND TWX'S

CORRESPONDFANCE FROM SIIPO-C

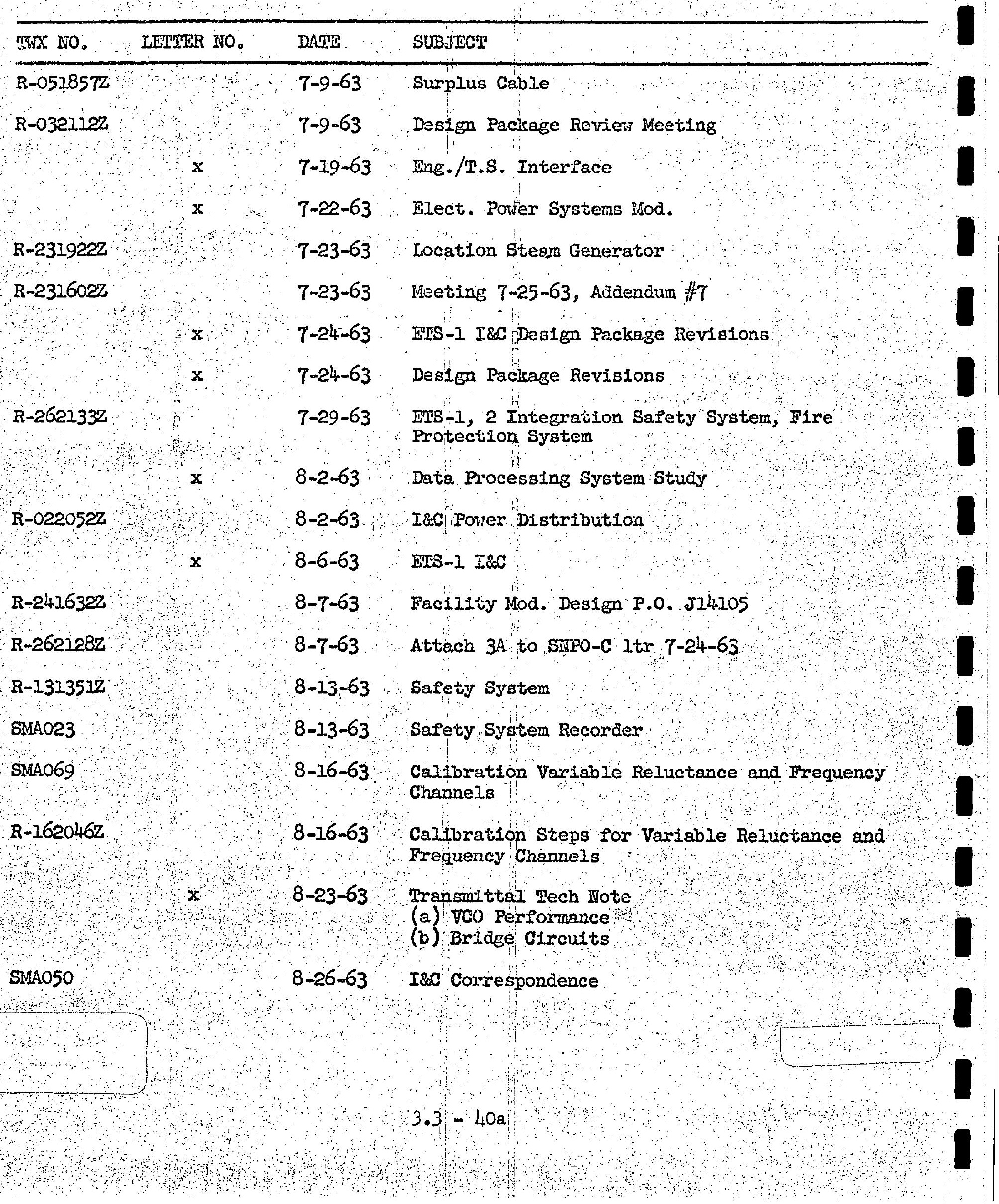


IFITIERS AND TWX'S

CORRESFOINDWHCE FROM SIPO-C

\begin{tabular}{|c|c|c|c|}
\hline T.T. NO. & UMJiR NO。 & DATE & SUBJECT \\
\hline$P-261850 Z$ & & $8-26-63$ & WIde-Band Recording System \\
\hline $\mathrm{p}-261901 \mathrm{Z}$ & & $8-26-63$ & EIS-I I\& Correspondence \\
\hline 006 & & $9-6-63$ & Iocation of Steam Generator \\
\hline$R-092045 Z$ & , & $9-10-63$ & Outline DDS Work statement \\
\hline$R-092028 Z$ & & $9-10-63$ & DDS Works Staterent \\
\hline.$\quad \because$ & $x$ & $9-10-63$ & InS-I I\&O Reliability \& Quality Assurance Plan \\
\hline & $\mathbf{x}$ & $9-17-63$ & Minutes of I\&C Meeting \#22 \\
\hline SNIAO 4.9 & & $9-19-63$ & $\mathrm{CBP}$ \\
\hline$R-271230 Z$ & & $9-27-63$ & I\&C Systems Cost Estimate \\
\hline
\end{tabular}

$3.3-41 a$ 


\section{S/T 3.4 TEST STAND ETS-2}

\section{ACCOMPLISHMENTS}

$W / S$

REFERENCE

$$
\text { 2-3.4(1) }
$$

SUPPORT

SNPO-C

\section{2-3.4(2)}

DOCUMENT

REVIEW

2-3.4(3) TECH ASSISTANCE ON

$I \& C$ SYSTEM
PLANNED

(a) PROVIDE DESIGN CRITERIA FOR ETS-2 DURING CONTRACT YEAR

(b) DEFINE INTERFACES AS REQUIRED

(c) PROVIDE UPDATED REQUIREMENTS AS REQUESTED

(a) PERFORM REVIEWS AS REQUESTED

(a) ASSIST AS REQUIRED
ACTUAL

(a) COMPLETED

(b) PERFORMED

(c) PERFORMED

(a) PERFORMED

(a) PERFORMED
EVIDENCE OF COMPLETION

(a) SEE BIBLIOGRAPHY FINAL REPORT *2502 DTD 7-12-63

(b) L741:039 DTD 9-19-63

(c) CONTINUING EFFORT

(a) MEETING MINUTES SNPO-C/REV 10-12-63

(a) CONTINUING EFFORT (REF. CY $64 \mathrm{~W} / \mathrm{S}$ ) 
Purpose and Objective

1. Support to SNPO-C

The A-E Phase I engineering analysis and design criteria report for ETS-2 was reviewed during August and September of CY 62 and October CY 63. Recommendations were discussed with SNPO-C and noted in conference notes/billings dated 12 October 1963. At this meeting SNPO-C directed REON to develop an ETS-2 basic criteria report. REON completed Report No. 2409 on 13 November 1962, and submitted preliminary copies to SNPO-C for review. Direction for revision of ETS-2 report, resulting from SNPO-C review, was received by REON in a letter dated 7 January. REON submitted the draft of the revised Report No. 2409 on 15 February. After review by SNPO-C during meeting on 27 February and as per directions in a letter dated 14 March, the report was again revised. At this time the report material was divided into two reports, No. 2506 and No. 2502, for ETS-I and ETS-2, respectively.

Report No. 2502 was reviewed by SNPO-C on April 11, revised and issued in May with a limited distribution.

On 26 June a joint SNPO-C/AETRON/REON meeting was held to discuss revisions to Report No. 2502 per comments delineated in the letter, SNPO-C to AGC, dated 13 June. REON again revised the report and made a final issue on $12 \mathrm{July}$. Final approval of Report No. 2502 was received from SNPO-C by letter, SNPO-C to REON, on 7 August 1963.

a. Per SNPO-C TWX dated 13 August 1963 requesting determination and methods of interfacing ETS-2 Facility Control System into ETS-1, REON 3.4 Subtask assisted Subtasks 3.2 in preparation of a Facility Control Interface Scope Study Report L741:0309 which was submitted on 19 september 1963.

b. Anticipating the $A-E$ requests for supplementary design requirement information, REON has been conducting evaluations on the latest Lockheed Tank Bottom Design concept and is accumulating available 
information for the A-E. Preliminary work was also done on establishing a design concept for the tank isolation valve.

2. A\&E Review

Except as noted in 1, a above, no effort was conducted during

CY 1963 on A\&E design review due to no release of contract effort by SNPO-C

to the A\&E which resulted in documents subject to REON review.

3. Technical Assistance on I\&C System

a. During the CY 1963, ETS-2 general I\&C requirements were included on Report No. 2502. Preparation of a detailed ETS-2 I\&C criteria is scheduled to be accomplished in CY 1964 when the ETS-I I\&C design has been firmed and the ETS-2 facility design concept has been established.

Conclusion

The efforts expended under Subtask 3.4 have met all of the Work Statement requirements, and the criteria produced for ETS-2 will greatly assist in expediting the A\&E phase of the program. 
TWX'S, IEITSERS, MEXEIINGS \& RETORTS

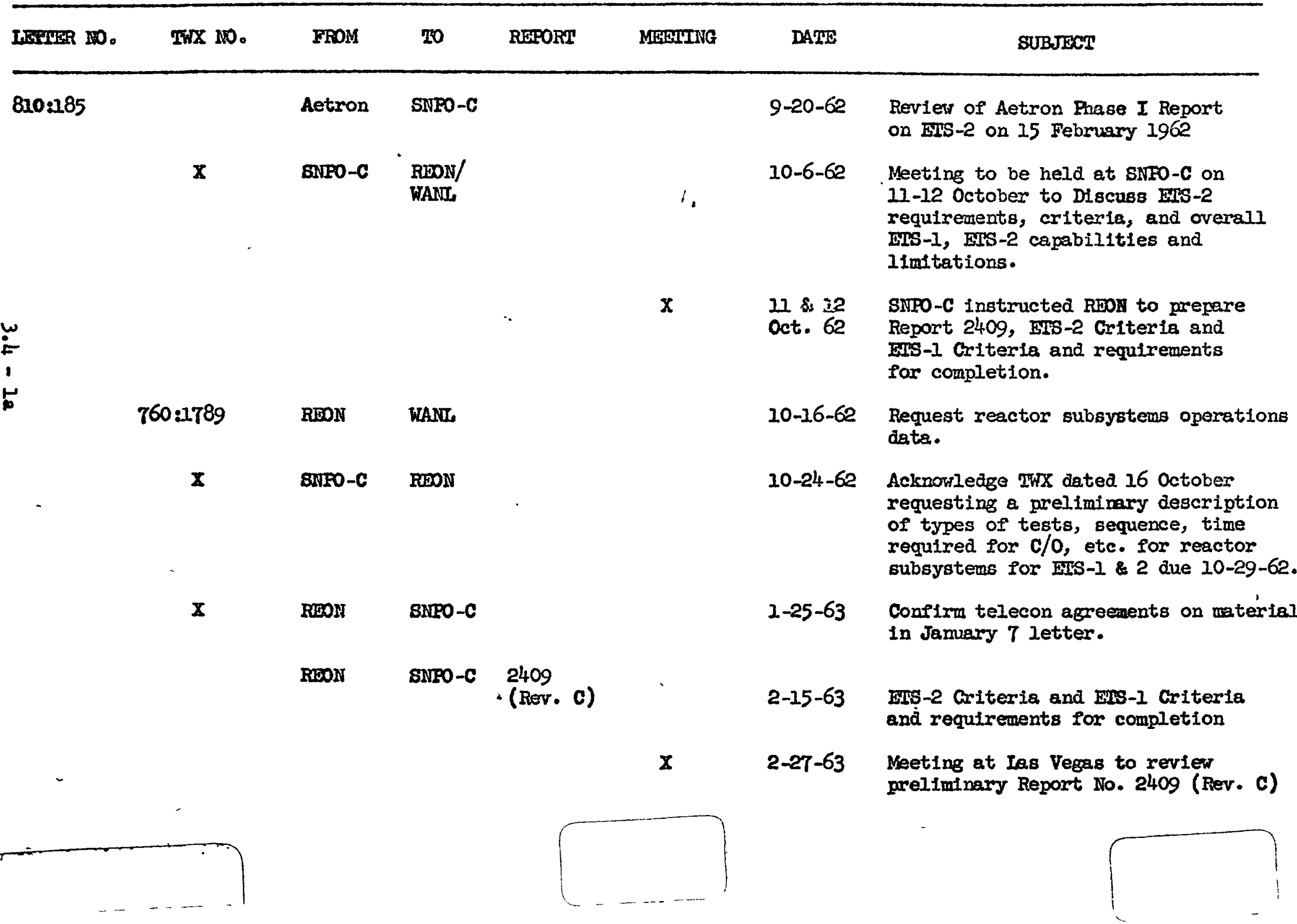


TWX'S, LEIJEERS, MEHEIIIVS \& RAFORTS

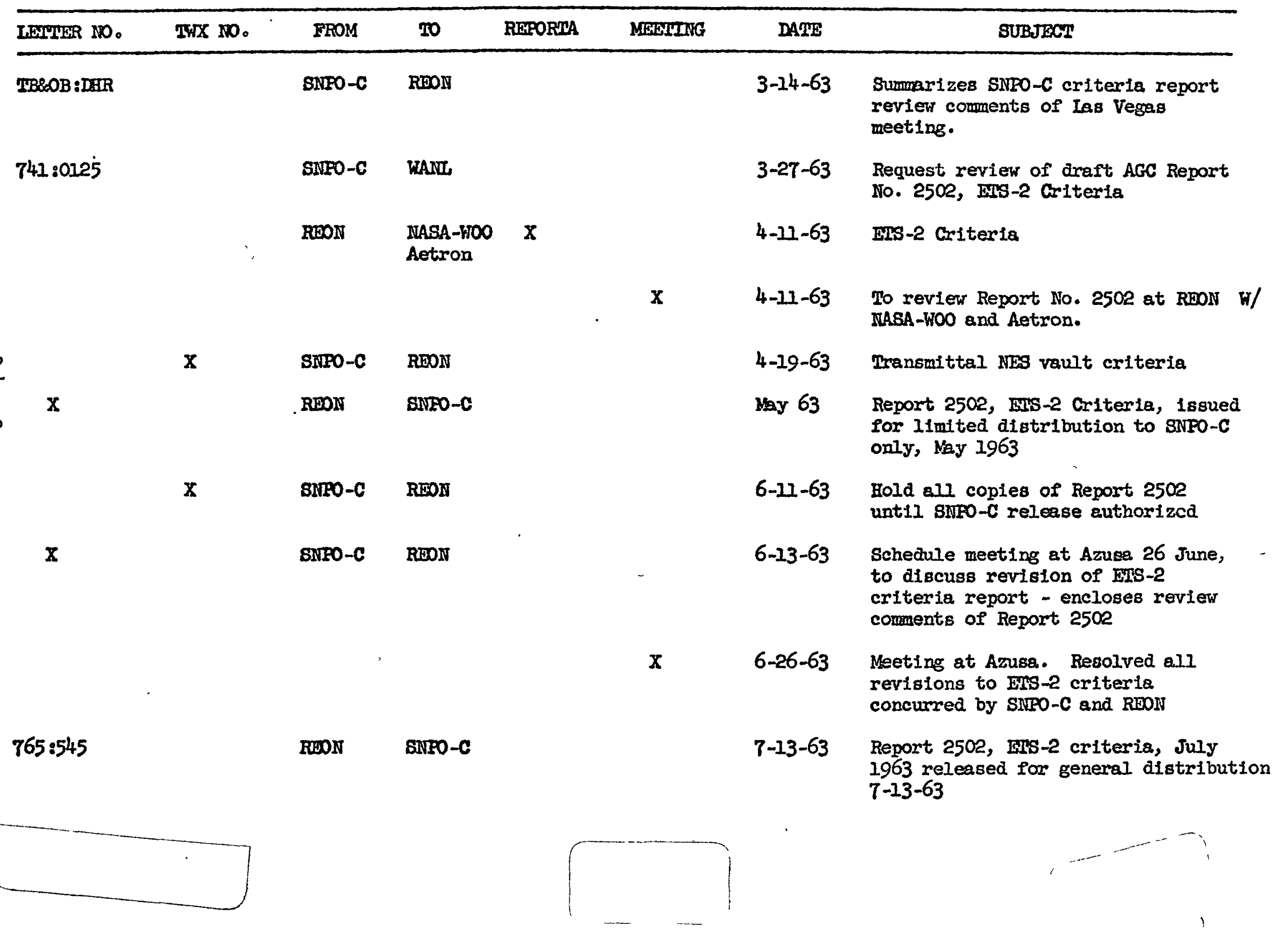




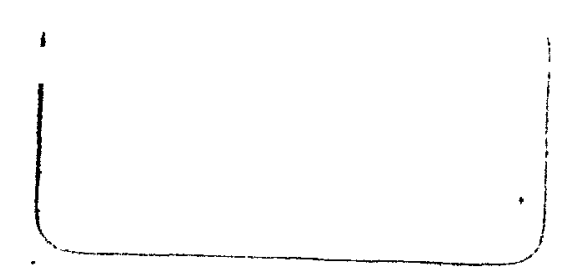

TWX'S, LETTERS, MQETINAS \& REPORTS

\begin{tabular}{|c|c|c|c|c|c|c|c|}
\hline LETTTR NO. & TWX NO. & FROM & To & REPORT & MEETTHO & DATE & SUBJECT \\
\hline & TSB:AL & $S N P O=C$ & REON & & & $7-\approx 9=63$ & $\begin{array}{l}\text { Request definition and nathods of } \\
\text { ETS-1/ETS } 2 \text { Electrical Control } \\
\text { Interface. }\end{array}$ \\
\hline \multirow[t]{3}{*}{$x$} & & SNPO_C & REON & · & & $8.7-63$ & $\begin{array}{l}\text { Approval of ETS-2 Criterta Report } \\
\text { No. } 2502 \text {. }\end{array}$ \\
\hline & $\mathrm{X}$ & SNPO $=6$ & REON & & & $8-12=63$ & Forvarding ETSo2 Schodule dates. \\
\hline & $x$ & REOU & SNPO $-C$ & & & $8-13-63$ & $\begin{array}{l}\text { Ansifer SNPO-C request for eleco } \\
\text { trical control lnterface study } \\
\text { plan and target date. }\end{array}$ \\
\hline FDO : J JR & & SNPODC & REON & & & $8-23-63$ & $\begin{array}{l}\text { Trenemittal of minutes of meoting } \\
\text { to discuss AETRON cost proposal } \\
\text { of ETS } 2 \text { studies. }\end{array}$ \\
\hline & $\mathbf{x}$ & REON & $\mathrm{SNPO}=\mathrm{C}$ & . & & $9.13-63$ & $\begin{array}{l}\text { Request copies of AETRON cost } \\
\text { proposal. }\end{array}$ \\
\hline & 741.0309 & REON & SNPO $=C$ & & & $9-19-63$ & $\begin{array}{l}\text { Submitted facility electrical } \\
\text { control interface study to SNPO-C. }\end{array}$ \\
\hline
\end{tabular}




\section{S/T 3.5 E-MAD FACILITY}

ACCOMPLISHMENTS

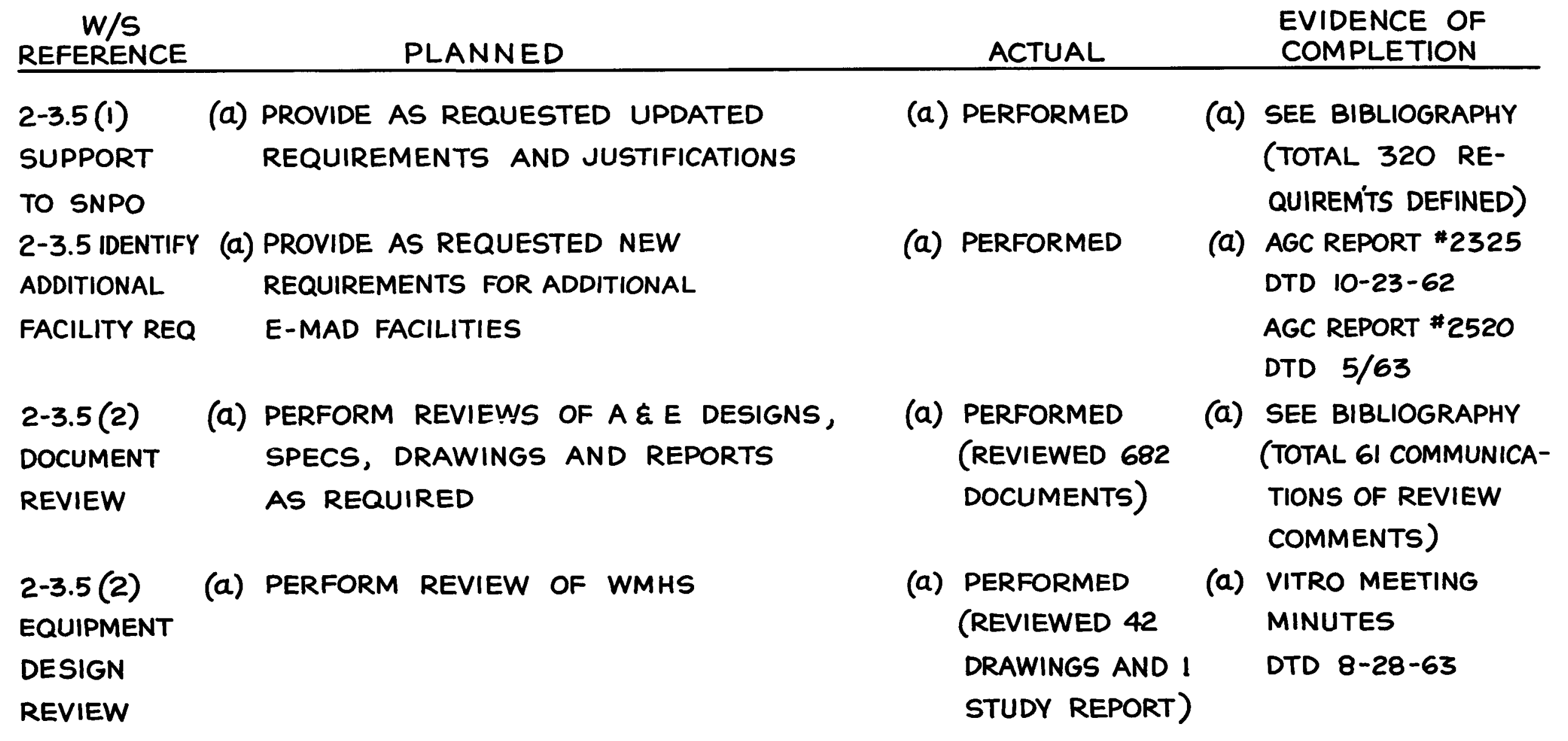




\section{S/T 3.5 E-MAD FACILITY \\ ACCOMPLISHMENTS}

$W / s$

REFERENCE

2-3.5 (3) ASSIST

IN FACILITY

ACTIVATION

PLANNING

SPECIAL REQUESTS

SNPO -C 5-14-63

CONDUCT FEASIBILITY STUDY

OF E-MAD TO ACCOMODATE

NRX

SNPO-C 5-14-63

$$
\text { PLANNED }
$$

(a) FOR E-MAD ACTIVATION

AS REQUIRED

CONDUCT STUDY TO

\section{COMPLETED}

COMPLETED

RECOMMEND PROCUREMENT

CATEGORIES FOR VARIOUS

E-MAD EQUIPMENTS
EVIDENCE OF COMPLETION

(a) CONTINUING STUDY PRELIMINARY REPORT IN PROGRESS

(d) $\quad$ L71:0264 DTD 9-13-63

(d) SEE BIBLIOGRAPHY (TOTAL 5 COMMUNICATIONS) 
SUBTASK 3.5 - ACCOMPLISHMENTS FOR CY 1963

Purpose and Objective

1. Support to SNPO-C

This task was engineering work on a level of effort with no milestones, and support was supplied to SNPO-C in the following manner:

a. Provided as requested and/or as the need indicated, updated NERVA requirements and/or SNPO-C requested justification on various subjects as evidenced by the 320 requirements defined, evaluated and transmitted in 18 TWXs, 29 letters and 2 reports and at the 12 meetings noted on bibliography. Example of such efforts resulting in correspondence are:

(1) REON review of hot cell doors - L741:0058,

8 December 1962.

(2) E-MAD composite safety review enclosing NERVA operations, functional and safety requirements for E-MAD building radiation monitoring, L741:0186, 13 May 1962.

(3) NERVA post operative requirements and load distributions for the E-MAD post-operative cells, L741:0078, 18 January 1963.

(4) Preliminary outline for E-MAD shielding integrity check, L741:0195, 17 May 1963.

(5) NERVA operational requirements for material transfer in E-MAD post-mortem cells, L741:0242 dated 27 June 1963, consisted of three enclosures, NERVA operational requirements for E-MAD post-mortem door interlocks and controls, schematic for E-MAD post-mortem doors, and NERVA operational requirements for the material transfer in and the ability of the post-mortem area less electrical interlocks.

The results of this effort have provided SNPO-C support in their direction of the A\&E effort. 


\section{Additional Facility Requirements}

a. Identification of additional E-MAD facility requirements were made as requested during the contract year and are noted in bibliography, Enclosure (4). This effort identified the facility requirements for critical parts storage, engine transport system maintenance and NERVA warm engine parts post-mortem. In addition to the meetings [Ref. Bibliography, Enclosure (4)], the results of this effort were transmitted by letter L741:0078 dated 18 January 1963, Report No. 2325 and Report No. 2520. (See Bibliography.)

3. Document Review

a. Facility document review of E-MAD building designs were conducted. Comments and/or approval was given on 605 drawings, 74 specifications and three reports received in 83 separate and unscheduled transmittals. REON completed review of all documents received and comments were expedited to SNPO-C by 61 TWXs, noted in bibliography Enclosure (2).

The average number of working days required, between receipt of material and transmittal of comments, was 13.4 days with a minimum of 2 and maximum of 39 days. A specific problem encountered during this review effort was the absence of the A\&E document release schedule. All reviews were therefore conducted on an unscheduled basis. Incoming transmittals varied from a minimum of one specification or report to a maximum of 116 drawings received in 1 day. REON transmitted 277 marked drawings and 80 marked specifications under cover of 15 letter of transmittals (see bibliography). Preliminary design and for-approval documents only were marked up for submittal.

The review effort performed was divided by the nature of the A\&E effort into the following major activities:

(1) The review of E-MAD Phase I construction changes, a total of 152 drawings and 10 specifications received in 23 transmittals. The response to SNPO-C with review comments required an average of 6.9 days with the minimum 2 days and the maximum 21 days (see bibliography). This material received priority over concurrent review effort of Phase II design. 
(2) The review of E-MAD post-mortem cells preliminary design was partially accomplished at meetings as noted in bibliography Enclosure (4), a total of 32 drawings. The review response time averaged 11.9 days with the minimum time 7 days and the maximum 24 days. For the subject 32 drawings, reference bibliography Enclosure (6).

(3) The review on E-MAD post-mortem cells final design included 256 drawings and 64 specifications received in 43 transmittals. These reviews were accomplished in an average of 15.1 days with the minimum 5 days and the maximum 39 days. [See bibliography Enclosure (7)].

(4) The "Certified for Construction" drawings for E-MAD Phase II were received in 6 transmittals and totaled 165 drawings. The average response with review comments was 7 days with the minimum requiring 1 day and the maximum 14 days. [See bibliography Enclosure (8)].

4. Equipment Design Review

REON participated as requested by SNPO-C in review of proposals for the wall mounted handling system procurement. Attendance at meeting and transmittal of review comments were made. Equipment design review was begun, per a SNPO-C supplied schedule, on the wall mounted handling system for the E-MAD east wall. REON reviewed 42 preliminary drawings, received one study report and participated in a technical conference August 27 and 28 (see bibliography). Formal transmittal of REON review comments was not made because of inadequacy and incompleteness of design as noted in Vitro Meeting notes september 1963.

\section{Facility Activation Planning}

Technical assistance on checkout and activation planning was provided as requested. However, no major requests were made to REON due to construction schedule readjustments into CY 1964. REON initiated early in the contract year an outline for and initiated compilation of E-MAD and support facilities operation data in preparation for activation efforts. The preliminary draft version is scheduled for printing in the first quarter of CY 1964. Activation planning was conducted throughout the contract year as 
required to assess manpower requirements, organizational structure, and preliminary efforts associated with determining support contractor activities.

\section{Special Requests}

Special studies over and above those required to support the A\&E design and construction effort were requested by SNPO-C and completed by REON were:

a. As requested by SNPO-C at the 14 and 15 May meeting and in program plans letter Schroeder to House dated 29 May 1963. REON initiated a three-phase program to complete a feasibility study of the E-MAD facility to accommodate the NRX. The three phases of the study program were:

Phase I Physical sizing of NRX to the E-MAD. This was transmitted by letter L740:0053 dated 4 June 1963.

Phase II Identifying special support equipment and facility requirement necessary to process an NRX through E-MAD, including floor space requirements for this equipment. This was transmitted by letter L740:0059 dated $25 \mathrm{June}$ 1963.

Phase III Identifying and describing all facility modifications, new facilities, and all additional equipment required to process NRX through E-MAD, considering NRX activities concurrent with E-engine operations. This was presented in a progress report in preliminary form by I741:0249 dated $12 \mathrm{July} 1963$ to verify that SNPO-C objectives had been satisfied. The draft study of the completed exercise was transmitted by letter 1741:0264 on 13 september 1963 which included 19 enclosures.

b. At the 14 May 1963 meeting, REON recommended all FY 1964 construction fund procurement items to be segregated in three categories with

$$
3.5-4
$$


the non-severable category being given the highest procurement priority. SNPO-C directed REON to study the recommended procurement categories and supply recommended quantity, type and description to meet minimum requirements and for procurement as part of E-MAD 1964 modification construction funds for

(1) General health and safety equipment

(2) General purpose fire protection equipment

(3) Machine shop equipment (Rooms 117 and 118)

(4) Physical counting room

(5) Personnel counting room

(6) Miscellaneous shop tools

(7) Master slave manipulator

(8) Rectalinear manipulator

(9) Office furniture.

This assignment was completed by transmittal of the following letters which are noted in the bibliography:

L740:0047 dated 28 May 1963 "REON recommended minimum equipment lists for E-MAD machine shop

L740:0048 dated 27 May 1963 "REON recommended minimum office equipment list for E-MAD

L740:050 dated 28 May 1963 "Recommendations for minimum rectilinear manipulator systems

L740:0052 dated 4 June 1963 "Recommended minimum general health and safety; general purpose fire equipment lists for E-MAD facility

During the course of this study the requirements were questioned by SNPO-C and justifications were required. The mechanical equipment fork lift trucks, industrial cleaning equipment, vault storage equipment, personnel counting room equipment, assay laboratory equipment and miscellaneous 
shop tools were removed from list as noted by the SNPO-C direction in the minutes of the meeting of $10 \mathrm{July} 1963$ (see bibliography). REON complied with SNPO-C direction to define total manipulator requirement for E-MAD by letter L741:0262 dated $31 \mathrm{July}$ 1962. This transmittal also included data relative to the most recently available new manipulator equipment (see bibliography).

7. Summary

Technical management and integration was supplied by maintaining continuous liaison with SNPO-C, subcontractors, NIS and related subtasks, with appropriate information distributed to those organizations contributing to assure compatibility of the E-MAD complex with other facilities and/or equipment and the adequacy of the facility to accommodate the functional, operational and safety requirements of the NERVA program. Meetings with SNPC-C were held as shown in bibliography Enclosure (4).

The volume of communications, in addition to phone calls, that was generated by this subtask totaled over 370 pages in approximately 100 TWXs and 40 letters transmitted to SNPU-C. In addition, dissemination of data was made to subcontractors and NTO. 
SUBTASK 3.5 - BIBLIOGRAPHY

SCHEDILE OF TWX AND LETTERS

TRANSMITTING REQUIREMENTS DATA

TWX DATE

REON MSG。

LETTER

TITLE OR DESCRIPTION

OR LTR NO.

DATE

$10-10=62$

$E \rightarrow$ MAD Phase II Design Requirements for Location of Borescope Periscope and Stereomicroscopo.

$10=21=52$

Service requirements for each post-mortem cell viewing window.

L74180043 10-26:62 Transnitted preliminary sketch SK=2661-01-1

Transfer Car Track lyout for ENAD。

$10=25 \times 62$

$13-21-62$

$10-21=62$

REON transmitted requirements relative to shielding critaria and calculations.

Ltr。 transmitted preliminary unedited rough draft of salient portions of NERVA Post Operativa Requirements document。

L730:2062: dh $\quad 10=23-62$

Transmitted smooth rough draft of sallent poro tions of NERVA Post Operative Requirements document。

$2741: 0045 \quad 10-31-62$

Encl。 (1) Area Warning System Summary

Encl. (2) Proposed Table of Safety AIarm and Warning Systems

$10-23-62$

1741:0014

$10-23-62$

Intercell Railway Door Shlelding and Anchoring Requirements。

Transmitted REON Drawing 037941 Transmitter Receiver Location Plan.

Er $\rightarrow$ MAD Alternates Procurement Priorities

$11-2-62$

$\begin{array}{ll}2741: 0058 & 1200.62 \\ 174180048 & 124-62\end{array}$

Trarsmitted "REON Review of Hot Cell Doors"。

"REON Review Comnents on EwMD Shielding Report" Vitro Report KLX 1842 。

$1-31-63$

EwAD Facility Wall Mounted Handling System Simultaneous motions.

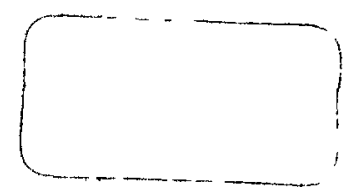


$\begin{array}{lll}\text { TWX DATE } & \text { REON MSG。 } & \text { IETTER } \\ & \text { OR LTR NO。 } & \text { DATE }\end{array}$
MITLE OR DESCRTPTION

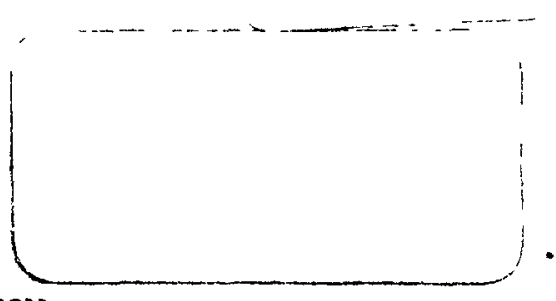

$\lambda=28-6 ?$

$1-22=63$

$1.7480073 \quad 3=13.69$

$1-14=63$

$1741.0000 \quad i=\therefore 0.63$

8-19-63 MSG。 ชoินz

$2-21-63 \quad$ MSG。99it

$[74180202 \quad 3=7063$

$3-25-63 \quad 1450,2236$
Requirement of Manipulators in the E-MAD Masuterance Bazcony

Operetional fnalysis including oost analysis or ecorumit values associated with the lift versus PJur dcors on the Hot Ce?A $2 \mathrm{~A}$ ExMAD Pnase II Procuremento

A deiaisen presentation (Bix enciosures) of the rest-opcrative zequirements and Ioad dia

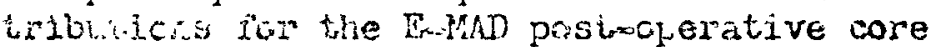

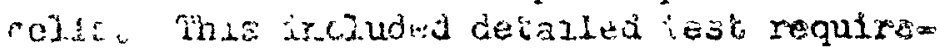

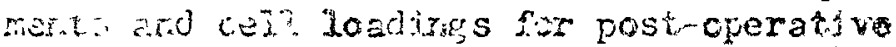

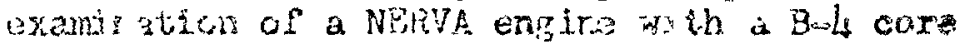
and wis ustd for expansion of REON Rsport 2325

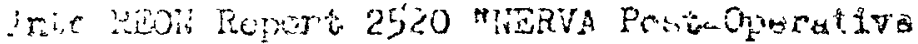

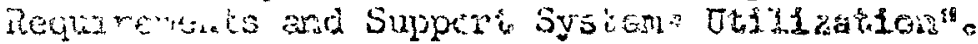

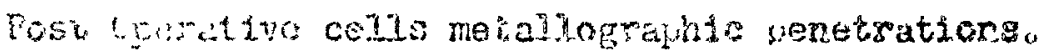

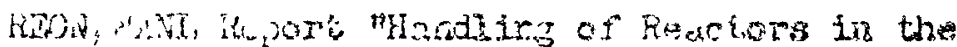

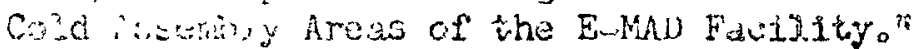

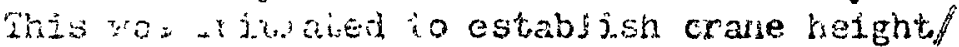
creacitomal reputzowerts arsd then modifying of

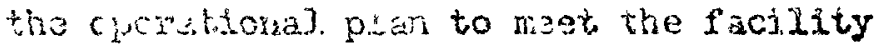
corkistising

Requi remsits for minimum ponetrations for mo besheraphic and mi ciohardnes. test equipment (se13a 165 and 166 )。

Openational requxenent for relocation of $p=4$ drawer and suggestud corner utilizationo

Desien data for Imbaddod liners in cell faco W2:

Fequ orerts for ExMD PostoOperative Cell Faces pilugs 


$\begin{array}{llll}\text { TWX DATE } & \text { REON HSG. } & \text { IETTER } & \text { TITLS OR DESCRIPTION } \\ & \text { OR LTR NO. } & \text { DATE } & \end{array}$

\section{$3-22=63$}

$3-26-63 \quad M S G 。 1285$

$1,740: 0044 \quad 40.2=63$

$4-12-63 \quad \mathrm{MSO}$ 。793

$4=22=73 \quad M S G 0942$

$2741: 0.162 \quad 4=26=53$

5.33 .63

274180.36

5.13 .63

$1741: 0271 \quad 5-i=63$

$1.741: 0295$

$5.17-63$

$274080047 \quad 3-28-63$

$5-27-63$

2740180048

$5-27-63$

174080049

$1740: 0050$

5.28 .63

Technical requirements relative to priority of E $\rightarrow$ MAD windows conforming to procurement inerementiso

Sido wall manipulators in EAMD Balcony。

Critars for control and safe operation of Post operative doors.

Requirement for oponing in plug doors to pros vide transfer capability betwe on cells 165 166 .

Requirements for 3 -inch dianeter pass through condults at windows on south end of cell service area.

Generaz Aree a afety Warning Systen for NRDS.

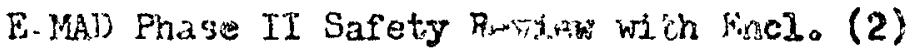
"NERVA Operailonal, Fupritional and Safety Requirenents for E-MAU Buliding Radiation Monftoringo"

Tran'inittal of REON sketch 2030 depieting thren alterrates for locating 3 -inch condults at W.ndows Sol0I and S=102。

Preliminary outline for EsMAD Shielding Integrity Check。

REON Recormended Minimum Equipment Lists for EwMA Machine Shop。

REON Recormended Minimum Office Equipment List for EmMAD。

REON Recommended Minimum Equipment Lists for ilsceilaneous Shop Tosis.

Reconmendations for Minimum Rectilinear Manipulo ator Systems。 
REON MSG。

IETTER

DATE

$2740: 0052$

$6=4 \times 63$

$1741: 0242$

$6-27-63$

L? $40: 0053$

$6=4=63$

$17408 \cos 7$

$6-17-63$

1.740:Cu59

$6-25.53$

I"141:50249

701.2063

L743:0245

$7-3-63$

L741:026?
$7-32-63$
TITLE OR DESCRIPTION

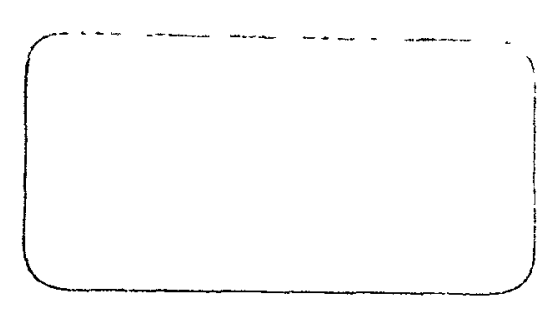


REON MSG 。 OR LTR。NO.

IFTTSR

DATE

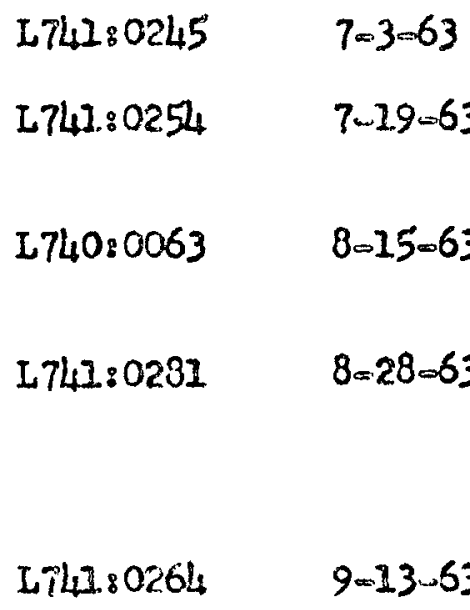

$9027-63 \quad M S G 。 1223$
TITLE OR DESCRIPTION

\section{Ray Plots}

EoMAD Viewing - Phase I Regults of REON Ray Plots transmitted on July 3, 2963.

Transmittal of EmMAD Machine Shop Floor Plan and Machine Tool Ariangement Drawing。

"Effects Cell Plug Doors have on NERVA Operations。 (Encl, 1) Chronological list of REON/WANL identification of plug door influence On NERVA referenced operational plan.

NRX Feasibility Study in book including 29 enclosures.

Power Tool, Requirements for WMHS - EMMAD, 


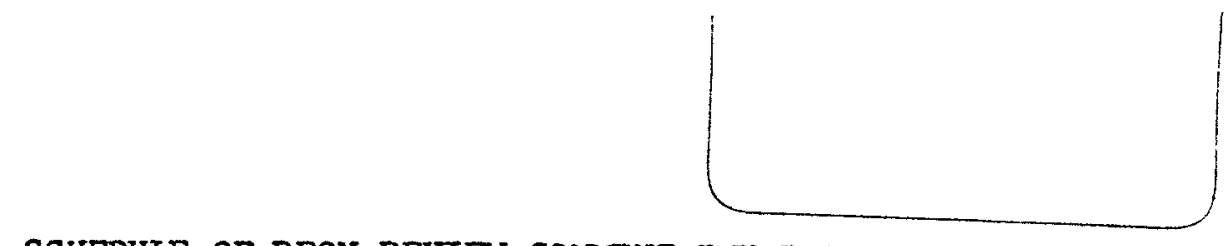

SCHEDULE OF REON REVIEW COMNENT TWX DATES AND THE

DRAWINGS AND SPECIFICATIONS REVIEWED

\begin{tabular}{|c|c|}
\hline $\begin{array}{l}\text { REVIEW } \\
\text { TWX } \\
\end{array}$ & DWGS, \& SPECS, REVIEWE \\
\hline 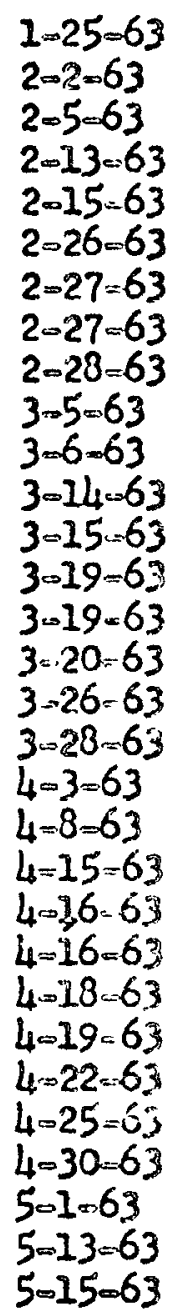 & $\begin{array}{l}26 \text { Drawing } \\
11 \text { Drawings } \\
9 \text { Drawings - } 2 \text { Spec。 } \\
11 \text { Drawings - I Spec。 } \\
10 \text { Drawings } \\
13 \text { Drawings } \\
6 \text { Drawings } \\
6 \text { Drawings } \\
5 \text { Drawings } \\
3 \text { Specification } \\
1 \text { Drawing } \\
7 \text { Drawings } \\
7 \text { Drawirgs } \\
7 \text { Drawirgs } \\
1 \text { Sketch } \\
4 \text { Drawirgs } \\
11 \text { Drawings } \\
7 \text { Drawings } \\
3 \text { Drawing } \\
8 \text { Drawings } \\
15 \text { Drawings } \\
5 \text { Drawings } \\
3 \text { Drawirgs } \\
3 \text { Drawings } \\
23 \text { Drawirg } \\
7 \text { Drawirgs a } 3 \text { Specs。 } \\
3 \text { Drawirgs } \\
14 \text { Speciflications } \\
48 \text { Drawings } \\
1 \text { Drawing } \\
17 \text { Drawings }\end{array}$ \\
\hline
\end{tabular}

REVIEW

TWX

DWGS \& \& SPECS. REVIEWED

$5-20=63 \quad 5$ Drawings

5=23-63 29 Specifications

$5031-6329$ Specifications

$6+6=63 \quad 6$ Dravings 1 Spac。

$6-11=63 \quad 11$ Drawlings

6012.6341 Drawings

601700632 Drawirge

$6-18 \approx 63 \quad 16$ Drawirigs

$6.20 .63 \quad 2$ Specifications

6-25-63 4 Specification

7-10-63 2 Drawings

$7-15=63 \quad 18$ Drawirgs

$7019=67 \quad 2$ Specificatizons

$7=26-63 \quad 3$ Drawings

8-21=63 97 Drawings

$8=26-63 \quad 28$ Drawing

3-26.063 I0 Drawirgs

3-27=63 $25 \mathrm{G}_{0} \mathrm{E}_{0}$ Drawlig

8. $30.63 \quad 16 \mathrm{G} \cdot \mathrm{E}_{0}$ Drairi.ugs

9.13-63 6 Drawings on I Spero

9-13-63 20 Drakirgs = 1 Sper。

9-13-63 R.F.C. L.4 Revislons

$9=23=63 \quad 5$ Drawings 22 Spees。

$9.23-63, R, F, C, 43$ Revisions

9-23-63 RoF。Co 46 Revisiond

9-23-63 Specification 1425 PS- LW

$9024=63$ Relocations of Amplidymes cer Vitro requesto

9.25.63 RoF。Co34 Revisions

9-26.63 11 Drawings - 1 Spec。

9-26.063 2 Drawling 02 Specs。 
SCHEDULE OF LETTERS TRANSMITTING DRAWINGS AND/OR SPECIFICATIONS MARKED WITH REON REVIEW COMMENTS AND REON REPORT REVIEWS

\begin{tabular}{|c|c|c|}
\hline LETTER NO. & DATE & MARKED DWGS \& SPECS, OR REPORT REVIEVS \\
\hline 1741:004? & $10.1706 \%$ & Review Comments of Specification $1425-$ PS- 4 \\
\hline $2742: 0035$ & $2-31-63$ & 16 Draw1rigs \\
\hline & $2-12-63$ & $\begin{array}{l}\text { REON/WANL Review Comments of "E=MAD Factling } \\
\text { Phase II Preliminary Design Report" KLXI34h - } \\
\text { Marked Copy of Report Air expressed to P. Renaso }\end{array}$ \\
\hline $1741: 009$ & $2 \infty 8 \cdots 63$ & 10 Drawings of 1 Specification \\
\hline L741:0127 & & .6 Drawings - 1 Specification \\
\hline L74I::00i:3 & .204 .63 & $\begin{array}{l}\text { ¿EON/WANL review of "ErMAD Nuclear Shlelding Report" } \\
\text { KJXI842 prollminary issve End ( } 1 \text { ) REON Reviow } \\
\text { Lomments on ENMAD Shielding Report KLXI84Z. }\end{array}$ \\
\hline Lifle:801C8 & $3-6-63$ & 12 Drawinga \\
\hline L74i:0102 & $3=7=63$ & ii Drawlings -1 Specification \\
\hline L74l.:011: & $3-5-63$ & 7 Drantings \\
\hline $2741: 018 i$ & $5-14-6 ;$ & 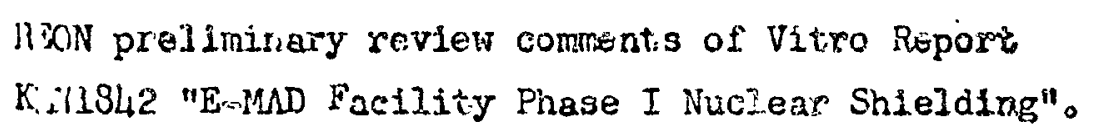 \\
\hline L.741:0136 & $5=13=63$ & $\begin{array}{l}\text { EuAd Phase I Safety Review Enciosure (I) Finel } \\
\text { Dl'uirgu and Specifications Safety Reviewo }\end{array}$ \\
\hline 1741.0180 & $5=9-6$ & 6) Drawings = 3 Specificácions \\
\hline 274180248 & 70963 & $\begin{array}{l}\text { loview Comments of Procurement Specification for } \\
\text { lanipuiator Assemblies }\end{array}$ \\
\hline$L 74180201$ & $5=27=03$ & s9 Drawinge ' \\
\hline 274780248 & 6.28 .63 & 53 Dranings \\
\hline L741:0220 & $6=17-63$ & 16 Specifieations \\
\hline L741:0210 & $6=7-6.3$ & So Speciflearions \\
\hline L741:0244 & $7=1-63$ & II. Drawings \\
\hline $2741: 0273$ & $3-9-63$ & i. Drawings $=6$ Specificarions \\
\hline
\end{tabular}


10-2 SNPO $C$ C/REON

1962

$\begin{array}{ll}10-3 \& 10-4 & \text { SNPO-C/Nitro/REON/ } \\ 1962 & \text { WANL }\end{array}$ WANL

11-13\& SNPDOC/Nitro/REON/

11-14-62 WANL

$12-11-62$ SNPO $C$ /NItro/REON/ WANI

$12-19-62$

SNPO-C/AANL/REON

$3-12-63$

SNPO-C/Nitro/REON
Establish Justification for E-MAD post-mortem Facilitles.

Establish Criteria for Phase II Prelioinary Design.

Evaluate the Scope of Phase II Preliminary Design。

Clarify design criteria for various post mortem cell design considerations.

Provide further juatif:cation of post-mortem cells.

Reviev E-MAD Phase II
None

REON was directed to define NERVA operational criteria and facilities itilization。

Adequate data was suprlied to permit completion of preliminary destgns. Also following the meeting, additional data was sup, iled on Viewing Adequacy, Intercell Rallroad Requirement and Instrument Penetration locations, sizes and types.

Thirteen action items developed relative to completion of requirements for Phase I and/or equipment. Vitro was suthorized to proceed with finalizing the post-mortem cells and office area designs.

Vitro authorized to work directly with NiF to resolve OPS interface problems. General arrangewent irawings accepted by all with minor stipulations. Cell face provisions require reviston to meet requirements and Vitro to proceed with design with minutes as firm design criteria.

KEON was atrec=ed to exponi justifica- None tion study of core post-mortem cells and warm engine parts post-mortom. Destgn, Scope of cell SNPO-C clarified items included in Phase II funding and items deferred from Phase I construction, thus the scope of room layout, view windows present design efforts were generally doors, and HVAC designs and defined. schedule of plans and spenificat can $^{2}$ ?
Vitro Letter of 10-8-62.

Vitro Letter of $11-16-62$.

Vitro Letter of $12-31-62$. 


\section{DATE}

$3-13-53$

\section{PARTICIPANTS}

SNPO-C/N1tro/REON

$4-4-63$

SNPO C/REON

w
ir
$\vdots$

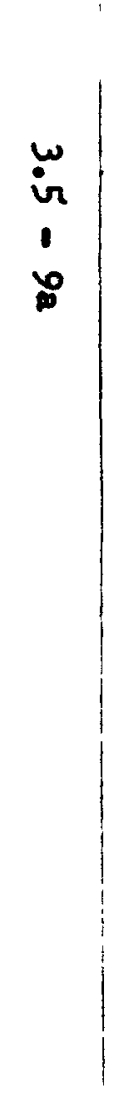

\section{PURPOSE}

Discuss technical proviston of Wall Mounted Bandiing System Proposals.

Discuss Post-Operative door interlock safety system, Fhase I Shielding Report and Radiation Monitoring Requirements。

Define the procurement status and plans for ExML Building and identify funding interfaces.

\section{RESULT}

Although all three proposals had several cases where they did not meet specification none were considered grounds for disqualification, and the merits of each case were to be considered when final recomendations vere formally presented to $A G C$ and Vitro.

It was agreed that RLON would conduct a composite safety review of all Phase I drawings and specifications and would formally present NERVA operational, functional and safety requiremente for E-MAD radiation monitoring. Both were accomplished by 1741:0186 dated 13 May 1963.

Program Requirements Handbook was described consisting of $P R D, P S P, O R$ and $O D$. SNPO-C supplied estimated dates of completion and scope of items procured with Phase I Construction Funds. REON segregated ENMAD FT 64 items into three categories and recommended the non-severable category be given highest priority - REON was directed to evaluate feasibility of NRX Assembly in the ENMAD Facility and to identify the problems, conflicts and additional requirements if any. This effort was to include concurrent NRX and E-Engine operations. REON was to provide Recommended Equipment Iists for procurement with E-MAD 1964 Modification Construction Funds.

\section{MINUTES}

Vitro Letter of 3-19-63.
REON Letter L741:0206 dated 4 June 1963. 
$6=4 \&$

$6-5-63$

SNPO-C/VITRO/REON/ WhNL

\section{$7=1-63$}

SNFU-C/RESN/WANL

Radiation Monitoring and Safety Allarm System ard ciarification of SNPO=C action or dectsiors rela $=$ tive to REON/WANL review comments previously trans ings and specifications.

To establish ard advise VITRO of changes to be made to Post-Mortem Celd. Interlocks and Room 176 service arrargements.

SNPOCC direction to VITRO relative to reviow comments and final. changes to Phase II deslign and certified for construetion issue of drawings and specio flcations. WANL
It was cgireed that Radiation Moritoring Systam did rict appear to affeet cono strumich and construction drawings for

future irstaliation and further decisions

cr systems design would be made at a

It was egreed that the requirement for rea Radiaticn Waming and Alarm for the seuth end of $E=M A D$ Buflding was an acicepted operational requirement and AGC was to define an audiowisual system. All review comments for Phase II that were tiransmitied to date vere discussed and resolved except for a list of hold items that were in transit.

PEJN presented L741:0242 dated 27 June 1963 on material transfer in the postmerstem cell area. VITRO was instruce ted to change high density blocks betwesn cells to a contractor furnishod and not installed item and temporary partitions are to be installed to balance the HVAC syrstem.

Additions to room 276 were directed as SNPO $=$ C/VITRO/REON outlined at the March 13 and 14 meeting. VITRO was directed to submit the 700 package refrigeration system for bid and the 200 and 300 packages (Post Mostem Cells and Office Area) were to he prepared "certified for construction".
REON Letter L74180239 dated 27 June 1963.
VITRO Letter dated 9 July 1963.
VITRO Letter datod 22 July 1963. 


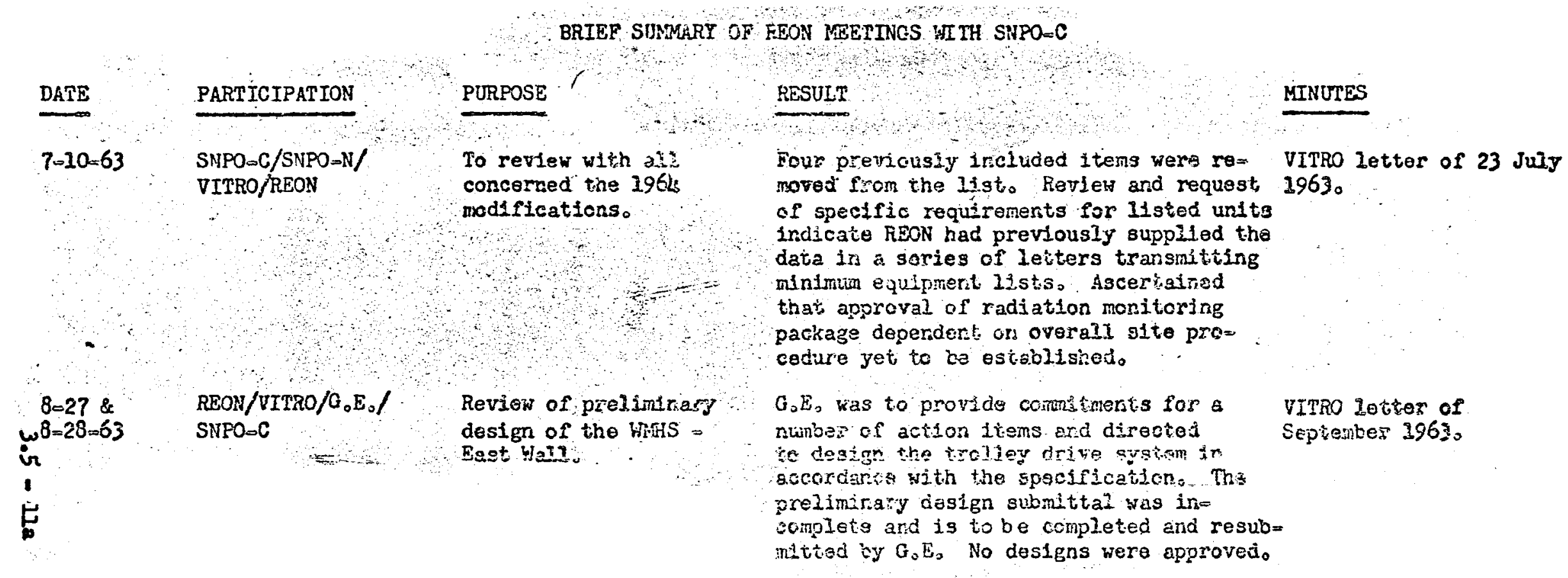


REON REVIEW ACTIVITIES ON EN-MAD PHASE I CONSTRUCTION CHANGES

Incoming Drawings \& Speciflcations

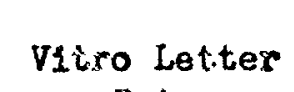

Dato

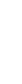

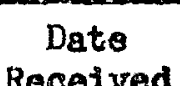

Received
Transmit+al of Review Commentes

\begin{tabular}{|c|c|}
\hline $\begin{array}{l}2-1-63 \\
2-20-63 \\
3-5-63 \\
3-7=63 \\
3-20=63 \\
3-25-63 \\
3-23-63 \\
4=1=63 \\
4=3-63 \\
4=3=63 \\
4-15-63 \\
4=16-63 \\
5-6-63 \\
5-10-63 \\
5-13=63 \\
5-16-63 \\
5-21-63 \\
5-23-63 \\
5=24=63 \\
9-3=63 \\
9=4=63 \\
9-4=63 \\
9-25-63\end{array}$ & 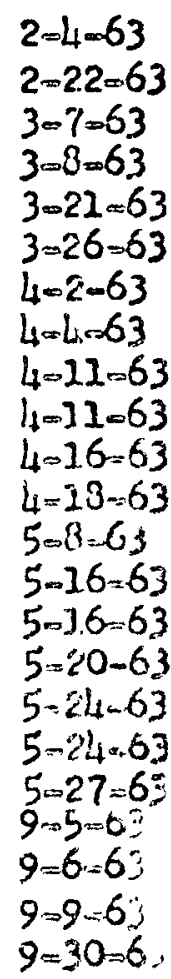 \\
\hline
\end{tabular}

$\begin{array}{ll}25 & 0 \\ 6 & 0 \\ 7 & 0 \\ 7 & 0 \\ 11 & 0 \\ 2 & 0 \\ 8 & 0 \\ 17 & 0 \\ 6 & 1 \\ 4 & 0 \\ 0 & 1 \\ 3 & 0 \\ 1 & 0 \\ 2 & 0 \\ 2 & 0 \\ 8 & 0 \\ 6 & 1 \\ 6 & 1 \\ 6 & 2 \\ 21 & 1 \\ 2 & 2 \\ 6 & 1 \\ 18 & 1\end{array}$

$2=13=63$

$2=27-63$

$3-15-63$

$3=29=63$

$3=26=63$

$4-25-63$

$4=3.63$

$4-19=63$

$4=23-4,3$

$4-17-63$

$4-30-63$

$4.25=63$

5 an $1=61$

$5-22-63$

$5-22-63$

5.22 .63

$6=25=-6 j$

$6=6-63$

$6-25+63$

$9+11=63$

$9-13=6$

$9011=0$.

$x c=3.6$

$\begin{array}{lll}\text { Response Tinis: } & \text { Mintmum } & 2 \text { daye } \\ & \text { Maximum } & 21 \text { Days } \\ \text { Average } & 6.9 \text { days }\end{array}$


REON REVIEN ACTIVITIES CF RDYHD FOST KRTEM CELLS PREIIITHAFY DESICN

\begin{tabular}{|c|c|c|c|c|c|c|c|}
\hline DRANING NUIBER & TITLE & $\begin{array}{l}\text { ROVISE } \\
\text { DRA:T:S NG:ER: }\end{array}$ & $\begin{array}{l}\text { REVISION } \\
M O=\text {, DATE }\end{array}$ & $\begin{array}{l}\text { TPLiIS. } \\
\text { DATE }\end{array}$ & $\begin{array}{l}\text { PECV. } \\
\text { REOY }\end{array}$ & $\begin{array}{l}\text { APPPDVED } \\
\text { IRAYS. }\end{array}$ & $00:=3=$ \\
\hline$I_{125}=\mathrm{K}-101$ & $\begin{array}{l}\text { Postoliorism Colls - A1r Flew } \\
\text { Diagran }\end{array}$ & $3425=k-20 i$ & $=12=23=63$ & $12=21=62$ & $22=26-62$ & $\begin{array}{l}1 i-14-6 \\
i 1=30-62 \\
12-1162\end{array}$ & $\begin{array}{l}\text { Yeetars } \\
\text { Tix } \\
\therefore 25 \text { in: }\end{array}$ \\
\hline $1425-10101$ & $\begin{array}{l}\text { Postollortein Celis = Typica? } \\
\text { Fase of Cell }\end{array}$ & $31 \times 25-1, y=20_{2}$ & $c / 2=23-63$ & $1=13=63$ & $1=21-63$ & $\begin{array}{l}32=11-58 \\
2-563\end{array}$ & $\begin{array}{l}\text { Peeting } \\
\text { Thix }\end{array}$ \\
\hline $2425-L-102$ & $\begin{array}{l}\text { Post-liorten Cei3s = Crax. } \& \\
\text { Manipulator Covesaga }\end{array}$ & $3-25-5$ & $1 / 3=4063$ & $3=13=63$ & $3=21-63$ & $\begin{array}{l}32=11-62 \\
4-1-5 i\end{array}$ & $\begin{array}{l}\text { Heasing } \\
\text { Thin }\end{array}$ \\
\hline $11,25=\mathrm{L}=106$ & $\begin{array}{l}\text { Post-kiortem Ceils o East \& } \\
\text { Vest Face Eleraticn }\end{array}$ & $1425-L=0$. & $i / i=53=6$ & $1=28=63$ & $1=21-63$ & $\begin{array}{l}12-11=62 \\
z=25=63\end{array}$ & $\begin{array}{l}\text { Neeting } \\
\text { Tix }\end{array}$ \\
\hline $1425=1:=20$ & PestoMortam Celis $=$ Piping & $1425=M=20 ?$ & $3 / 1-3-63$ & $1=4-63$ & $1=7=63$ & $1=25=63$ & TWX \\
\hline $2425=11=i C$ & $\begin{array}{l}\text { Fosthorten Catiz = Pipirg } \\
\text { Diegram Vicst: }\end{array}$ & $11425=28=205$ & $3 / 2=3=63$ & $1-4=53$ & $I=7=53$ & $I=25-5 ?$ & $T W X$ \\
\hline $1425=\mathrm{N}-\mathrm{K} 0 \mathrm{O}$ & 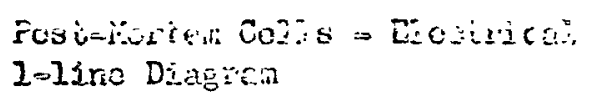 & $3 \dot{2} 25=\ddot{y}=20 ?$ & $4 / j=25=6 j$ & $1=28=63$ & $1=3 i=63$ & $\begin{array}{l}32=1 \hat{i}=6 i \\
2=12=5 i\end{array}$ & $\begin{array}{l}\text { Doetifise } \\
\text { TLX }\end{array}$ \\
\hline $1425-R-124$ & $\begin{array}{l}\text { Pasiblortem Colis = Pactiai } \\
\text { Plans Effeci (Schenatic } 4 \text { ) }\end{array}$ & & & & & & \\
\hline$U_{1} \sum 5=R=125$ & $\begin{array}{l}\text { Postiliortem Celis a Partialal } \\
\text { Plans Efiect (Echenatio } 5 \text { ) }\end{array}$ & $11.25-R=20: 5$ & & & & & \\
\hline $14,25-R=126$ & 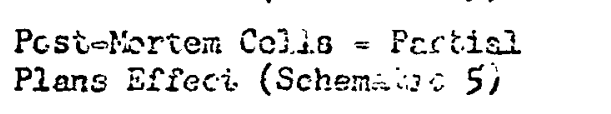 & $\begin{array}{l}2425-R=: 0 ? \\
2425-8=63\end{array}$ & $2 / 32=20=62$ & $12=21-62$ & $12-26=62$ & $\begin{array}{l}12=11=52 \\
1=9=53\end{array}$ & $\begin{array}{l}\text { Meeting } \\
\text { Thx }\end{array}$ \\
\hline $1425=R=1<3$ & 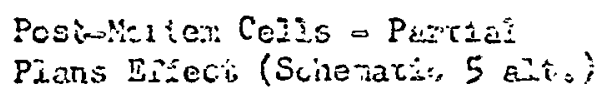 & & & & & & \\
\hline $1425=129$ & 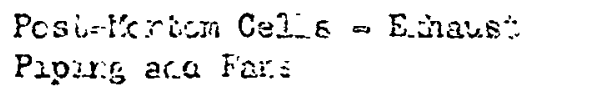 & $9 j 20.5-K=200$ & $2 / 2 \div 3-63$ & $2=11-63$ & $2-14=53$ & $\begin{array}{l}12-13=62 \\
2-27=63\end{array}$ & $\begin{array}{l}\text { Meeting } \\
\text { TwX }\end{array}$ \\
\hline & & & Response Ty & \multicolumn{2}{|c|}{$\begin{array}{l}\text { Mirimuan } \\
\text { Maximina } \\
\text { Average }\end{array}$} & $\begin{array}{l}7 \text { daj's } \\
24 \text { dsyrz } \\
11.9 \text { days }\end{array}$ & \\
\hline
\end{tabular}


REON REVIEW ACTIVITIES ON E-MAD POST MORTEM CELLS FINAL DESION

Incoming Drawings \& Speciflcations

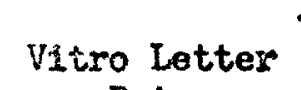
Dato

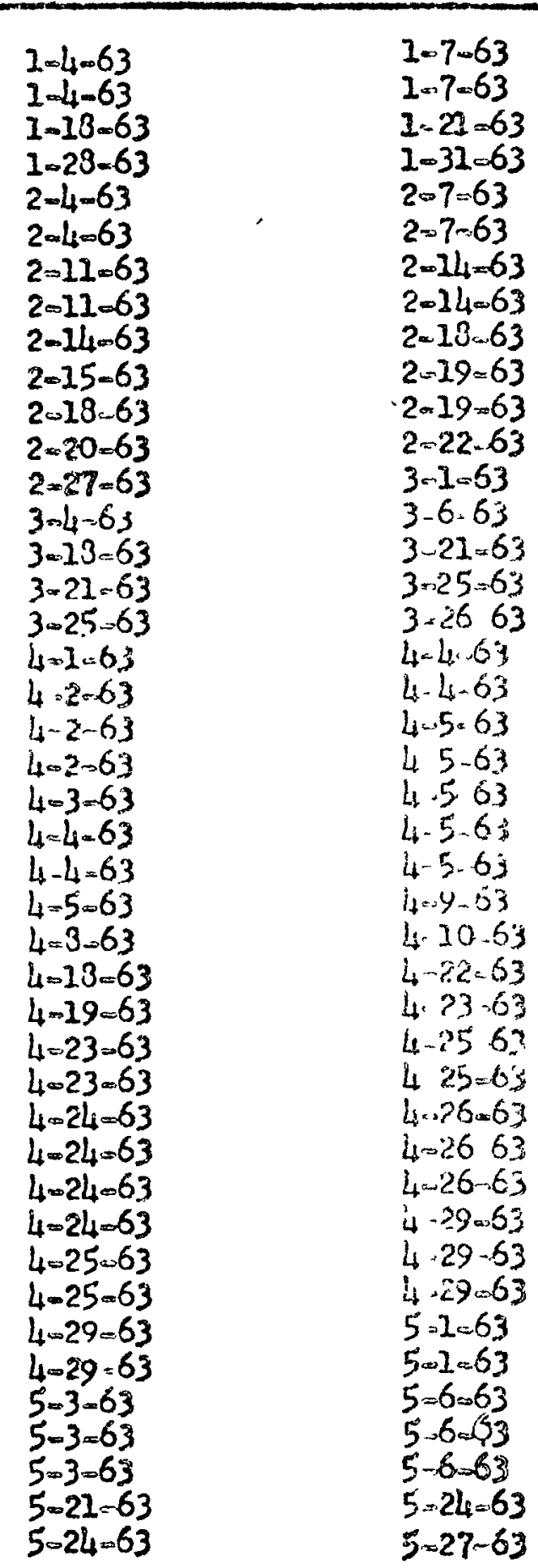

Trangmittal of Review . Comments
Number of Number of

Drawi.ngs Specs。

\begin{tabular}{|c|c|c|c|}
\hline 21 & & 0 & $1-25 \times 63$ \\
\hline$\lambda$ & & 1 & $2-5-63$ \\
\hline 8 & & $\overline{0}$ & $2-5 \times 63$ \\
\hline 17 & & 1 & $2-13-63$ \\
\hline 10 & & 0 & $2-21-63$ \\
\hline 2 & & 0 & $2-27-63$ \\
\hline 5 & & 0 & $2-27-63$ \\
\hline 2 & & 0 & $3-6.63$ \\
\hline 3 & & 0 & $2-27-63$ \\
\hline 0 & & 1 & 3.6 .63 \\
\hline 4 & & 0 & $2-23=63$ \\
\hline 5 & & 0 & $3-15-63$ \\
\hline 2 & & 0 & $3-15 \cdot 63$ \\
\hline 4 & & 0 & $3-13.63$ \\
\hline 5 & & 0 & $4-4=63$ \\
\hline 3 & & 0 & $4-9-63$ \\
\hline 10 & & 0 & $4-15-63$ \\
\hline 3 & & 0 & $4-19-63$ \\
\hline 4 & & 0 & $4-17=63$ \\
\hline is & & 0 & $4-15-63$ \\
\hline$i$ & & 0 & $L=019=63$ \\
\hline$y$ & , - & 1 & $4-30-09$ \\
\hline$\therefore$ & & 0 & $4-17-63$ \\
\hline$C^{\prime}$ & & 2 & $4=23-63$ \\
\hline$\therefore$ & & 0 & $4=17.63$ \\
\hline$e$ & & 0 & $40 x 9=63$ \\
\hline $2 l_{i}$ & & 0 & $5-1=63$ \\
\hline 27 & & 0 & $5-1-63$ \\
\hline 0 & & 15 & $5-23-6 x$ \\
\hline$r$ & & 11 & $5-3 i=63$ \\
\hline 2 & & 0 & $5=15=63$ \\
\hline $3:$ & & 0 & $5015=63$ \\
\hline 3 & & 0 & $6-14 \cdot 63$ \\
\hline in & & 0 & $6-14=63$ \\
\hline 11 & & 0 & $6-11=63$ \\
\hline 30 & & $\infty$ & $6=14-63$ \\
\hline 7 & & 0 & $6-14=63$ \\
\hline 31 & & 0 & $0-19-63$ \\
\hline 0 & & 7 & $5-23-63$ \\
\hline 0 & & 22 & $5-31-63$ \\
\hline () & & 2 & $6-20-63$ \\
\hline 2 & & 1 & $6-19-63$ \\
\hline$\therefore$ & & 0 & 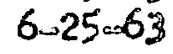 \\
\hline
\end{tabular}

\begin{tabular}{lll} 
Responseg & Minimua & 5 days \\
& Maximum & 39 days \\
& Avexags & 1501 days \\
\hline
\end{tabular}


REON REVIEN OF PIIASE II

"CERTIFIED FOR CONSTRUCTION" DRAWINGS

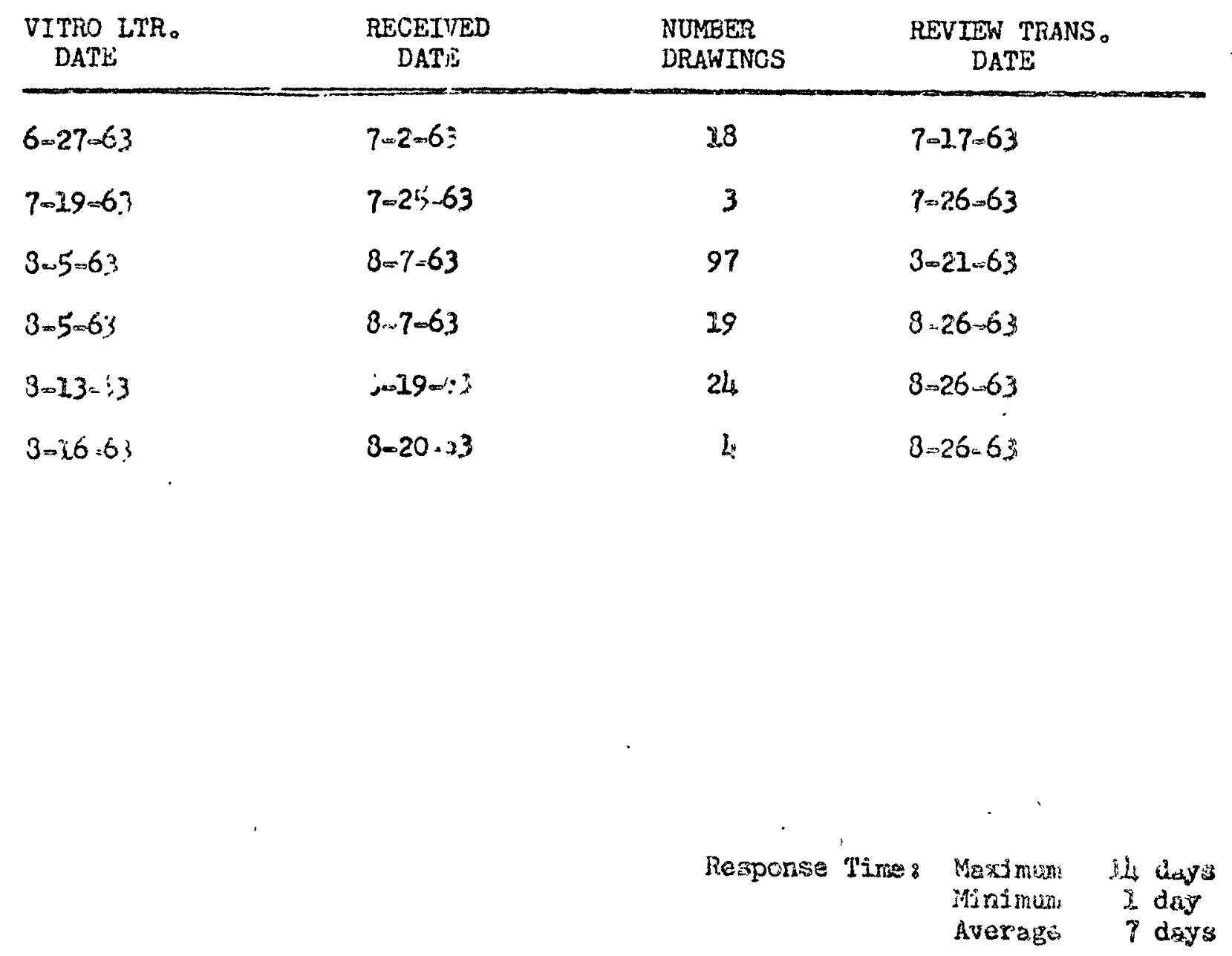


BIBLIOGRAITY FOR

SUBRASK 3.5

B-IZAD

CORRESFONDDHCE IROM SMTO-C

\begin{tabular}{|c|c|c|c|}
\hline $\operatorname{Tx} x$ & IETDTER & DATE & SUBJECT \\
\hline & $x$ & $10-9-62$ & Recosmended Sirrollfied Warning and Alarm Sybtem. \\
\hline $\mathbf{x}$ & & $10-10-62$ & Warm Rachine Shop. \\
\hline \multirow[t]{6}{*}{$\mathbf{x}$} & & $20-10-62$ & Reconniended Hethod of Inadjing the Core. \\
\hline & $\mathrm{x}$ & $10-21-62$ & Fost-Morten Cell Criteria Required. \\
\hline & $\mathbf{x}$ & $11-2-62$ & $\begin{array}{l}\text { Request for Proposal SNPDO-C-56564, Addendum \#1 } \\
\text { Wail Houated Handling SyBters. }\end{array}$ \\
\hline & $\mathbf{x}$ & $21-8-62$ & Evaluation or Wall Mounted Hanaling System. \\
\hline & $\mathrm{x}$ & $11-20-62$ & $\begin{array}{l}\text { NERVA Post-Operative Requirement and Support } \\
\text { Systcm Utilization. }\end{array}$ \\
\hline & $\mathbf{x}$ & $11-23-62$ & E-BAD Shielaing \\
\hline $\mathbf{x}$ & & $1-22-63$ & MASA Rev1ew of Preliminary Draw1ngs. \\
\hline$x$ & & $2-6-63$ & $\begin{array}{l}\text { Review of Vitro Fasase II Prelininary Design } \\
\text { Report. }\end{array}$ \\
\hline \multirow[t]{2}{*}{$x$} & & $2-6-63$ & $\begin{array}{l}\text { Quality Assurance for the U. II Nounted Handling } \\
\text { System. }\end{array}$ \\
\hline & $\mathrm{x}$ & $2-26-63$ & $\begin{array}{l}\text { VITRO JOB } 1425 \text { - Post-Bortem Cell Shieldings } \\
\text { Hindows. }\end{array}$ \\
\hline $\mathbf{x}$ & & $2-27-63$ & Priority on Viewsig Windows. \\
\hline $\mathbf{x}$ & & $2-28-63$ & Phase II Post-kforten Cells - Selection of Doors. \\
\hline $\mathbf{x}$ & & $3-6-63$ & Meeting - Review of Fhase II E-MAAD Desiga. \\
\hline$x$ & & $3-11-63$ & Deslep Review Rseciln \\
\hline $\mathbf{x}$ & & $3-12-63$ & $\begin{array}{l}\text { Frovisions for Elimination of Hazard from } \\
\text { Runaway U Cars from the Railroad. }\end{array}$ \\
\hline
\end{tabular}




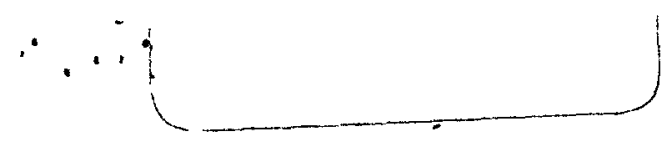

CORRISSFOHDENAE FROSA SNPO-C

\begin{tabular}{|c|c|c|c|}
\hline TWZ & LETPTER & DATE & SUBJECP \\
\hline & $x$ & $3-21-63$ & Argonne Coments on the E-MAD Fucility. \\
\hline & $\mathbf{x}$ & $3-22-63$ & E-MAD Facility, Phase II. \\
\hline $\mathbf{x}$ & & $3-27-63$ & hitis Bidders Coments. \\
\hline $\mathbf{x}$ & & $3-28-63$ & $\begin{array}{l}\text { Inforzation Required for Wall Kounted Handling } \\
\text { System. }\end{array}$ \\
\hline $\mathbf{x}$ & $\begin{array}{l}x \\
x\end{array}$ & $\begin{array}{l}3-29-63 \\
4-1-63 \\
4-2-63\end{array}$ & 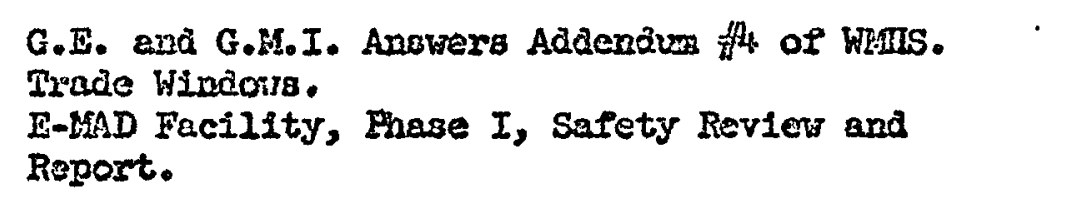 \\
\hline $\mathbf{x}$ & & $4-8-63$ & $\begin{array}{l}\text { Eudget Lobosatory TIme Ecuf gment for E-bad } \\
\text { CI } 64 \text {. }\end{array}$ \\
\hline & $\mathbf{x}$ & $4-15-63$ & $\begin{array}{l}\text { E-IEAD Facility, Faase II, Post-Hiortera Cells, } \\
\text { Proposed REONI Door Interiocir Schematic, Etc. }\end{array}$ \\
\hline & $x$ & $4-18-63$ & Revier of E-MAD, Phaze II, Prelininary Drewings. \\
\hline & $\mathbf{z}$ & $4-18-63$ & Hot Box Fac1lity at WIS. \\
\hline & $\mathbf{x}$ & $4-19-63$ & Scheduliog of E-MAD Phase II Design. \\
\hline & $x$ & $4-23-63$ & Filase II Post-lfortem Cell Vlewing Hindow Size. \\
\hline & 女 & $4-24-63$ & EWHAD Facility, Fheze II, IVAC Corraents. \\
\hline & s & $4-26-63$ & Finase II Construction Dravinga, Review of \\
\hline & $\mathbf{x}$ & $4-30-62$ & E-FAn Facility Viouing Window Priority Assignesent. \\
\hline & $\mathbf{x}$ & $5-2-63$ & EnHAD Fostmbartea Cell Door and Loek. \\
\hline & $z$ & $5-10-63$ & OIS Arrangenent Dratringe. \\
\hline & $\mathrm{x}$ & $5-13-63$ & Stde Hull Ranipulators Mounting E-MAD Buslalag. \\
\hline & $\mathrm{x}$ & $5-17-63$ & $\begin{array}{l}\text { Reviev of Additionel Funds for Design and } \\
\text { Congtruction of the E-RRAD Building. }\end{array}$ \\
\hline $\mathbf{x}$ & & $5-20-63$ & E-MAD 1964 ModiRications \\
\hline & $\mathbf{x}$ & $5-27-63$ & E-LAD Vendor Drawinga. \\
\hline
\end{tabular}


CORRESFOMDENCE FROH SNFO-C

\begin{tabular}{|c|c|c|c|}
\hline $\operatorname{Tr} x$ & IEITER & MATS & SUBJECI \\
\hline & $x$ & $5-27-63$ & E-MAD, AGC Phase II Desien Review. \\
\hline & $\boldsymbol{X}$ & $5-27-63$ & Phare II E-KAD. \\
\hline & $\mathrm{x}$ & $5-29-63$ & Change Order Frocedure. \\
\hline & $\mathrm{x}$ & $6-13-63$ & E-kinD Facility, OPS Design Data Interfece. \\
\hline & $\mathbf{x}$ & $6-13-63$ & E-MAD Vieving Hindows. \\
\hline & $x$ & $6-14-63$ & EIS-I and E-MAD Fhase II PKRT Report. \\
\hline \multirow[t]{2}{*}{$\mathbf{x}$} & & $6-19-63$ & $\begin{array}{l}\text { Froposed Meeting on E-BUD R diation lfonttorlag } \\
\text { Syrtem and Shielding Integrity Check. }\end{array}$ \\
\hline & $\mathbf{X}$ & $6-18-63$ & E-MAD Fac1lity, OPS Des1gn Dita Interfacing. \\
\hline \multirow[t]{5}{*}{$x$} & & $6-19-63$ & E-MAD 200 Setiez Drarings, Hot Cells. \\
\hline & $\mathbf{X}$ & $6-20-63$ & E-MAD Fazse II Safety Review. \\
\hline & $\mathbf{x}$ & $6-20-63$ & $\begin{array}{l}\text { E-HAD } 2964 \text { Bodiflcation, Wall Bandilng Systen } \\
\text { (Mesi Hall). }\end{array}$ \\
\hline & $\mathrm{x}$ & $6-22-63$ & E-12DD Certified Print Distribution. \\
\hline & $\mathbf{x}$ & $6-26-63$ & $\begin{array}{l}\text { E-MaD, Hall kounted Handling Systen, West Wull } \\
\text { Units. }\end{array}$ \\
\hline \multirow[t]{4}{*}{$x$} & & $6-27-63$ & E-KAD, PaEse II. \\
\hline & $\mathbf{X}$ & $7-1-63$ & $\begin{array}{l}\text { E-MAD, Fase II, Fost-Borten PIus Dcor Rewoval } \\
\text { PIus ErovisIons. }\end{array}$ \\
\hline & $x$ & $7-2-63$ & 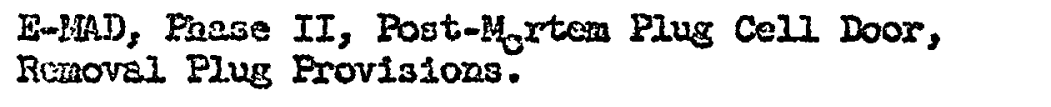 \\
\hline & $\mathrm{x}$ & $7-3-63$ & $\begin{array}{l}\text { E-wAD, 1964 Moasfleations Railroed Rewote Control } \\
\text { Switches. }\end{array}$ \\
\hline \multirow[t]{3}{*}{$\mathbf{x}$} & & $7-11-63$ & Technical Direction Heeting. \\
\hline & $\mathbf{x}$ & $7-13-63$ & E-MAD Building, Eoak Travel Overhead. \\
\hline & $\mathbf{x}$ & $7-16-63$ & E-MAD Vendor Data Distribution. \\
\hline
\end{tabular}

$3.5-18 a$ 


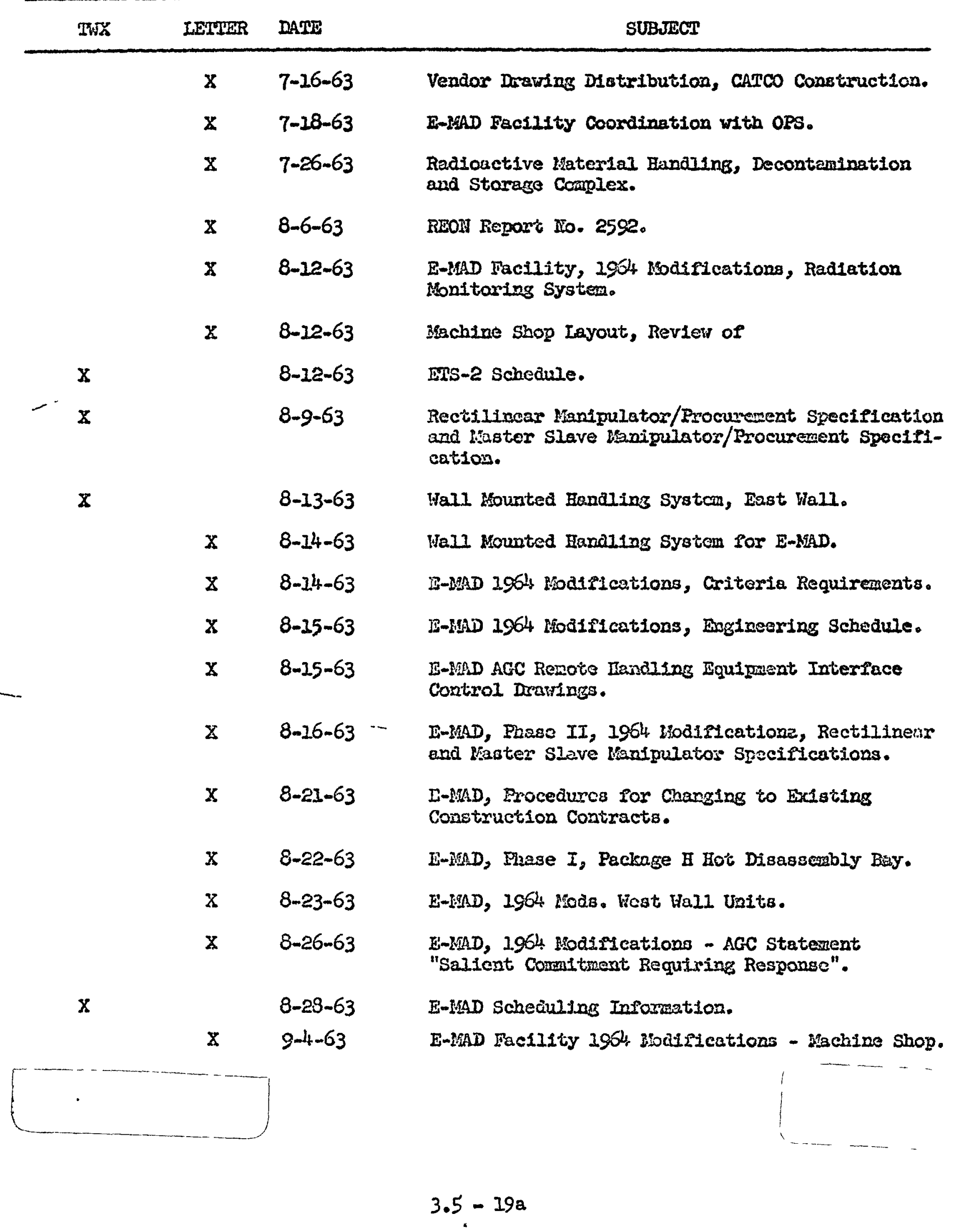




\begin{tabular}{|c|c|c|c|}
\hline TwX & IDETITER & DATE & SUBJECP \\
\hline & $\mathbf{x}$ & $9-5-63$ & E-BAD Facillty 1964 Modiflcations, Machine Shop. \\
\hline & $x$ & $9-5-63$ & E-MAD, Phase II Scopo Drawsings. \\
\hline & $\mathbf{x}$ & $9-9.63$ & F-MAD, Phase II Drawings and Speciflcations. \\
\hline & $\mathbf{z}$ & $9-9-63$ & $\begin{array}{l}\text { E-lKAD, Fhase II AGC Review of Certified for } \\
\text { Construction DrasingB. }\end{array}$ \\
\hline & $\mathbf{x}$ & $9-18-63$ & $\begin{array}{l}\text { E-BND } 1964 \text { Rodifications - Radiation Ronitaring } \\
\text { Systex. }\end{array}$ \\
\hline $\mathbf{X}$ & & $9-19-63$ & $\begin{array}{l}\text { E-MAD Facility } 1964 \text { Nods. - Eogineerlag Cost } \\
\text { Estinate. }\end{array}$ \\
\hline
\end{tabular}

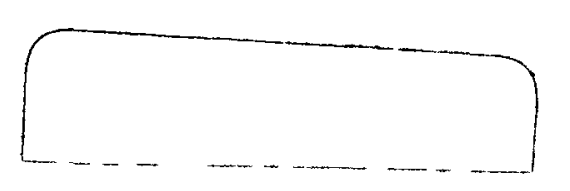




\section{S/T 3.6 REACTOR DEVELOPMENT FACILITY}

ACCOMPLISHMENT

\begin{abstract}
$W / s$
REFERENCE

2-3.6(1) SUPPORT
\end{abstract}

TO SNPO-C

2-3.6(1) DEVELOP

FACILITIES

REQUIREMENTS

2-3.6(1) REVIEW

DOCUMENTS

2-3.6 (1) ASSIST

C/O AND

ACTIVATION
PLANNED

(a) PROVIDE ANALYSIS AND

STUDIES AS REQUESTED

(a) PRODUCE REQUIREMENTS AS REQUESTED

CONDUCT REVIEWS AS REQUESTED

PROVIDE TECHNICAL

ASSISTANCE

AS REQUESTED (a) PERFORMED

ACTUAL

(2) PERFORMED

PERFORMED

PERFORMED
EVIDENCE OF COMPLETION

(a) REON REPORT 2433 DTD 12/28/62 WANL TME 097 WANL TME 279 WANL TME 340 WANL TME 374 REON REQUEST*2703 DTD $9 / 63$

(SEE TASK 1.1 )

PREPARED AND ISSUED FOR APPROVAL 12 FACILITIES MANUALS 
Purpose and Objective

1. Support to SNPO-C

a. A study was conducted to evaluate Test Cell "A" utilization as an interim stand for E-Engine testing. This effort was reported in REON Report 2433, 28 December 1962. The results of the study indicated feasibility of using TCA for this purpose with only nominal modifications.

b. NRX documentation was reviewed to assess the adequacy of Test Cell "A" support and for coordination and dissemination of data. Pertinent reports evaluated were (1) the NRX-A-1 test plan, WANL TNR 097; (2) NRX-A-1 test specification, WANL TNR-121; (3) NRX-A-1 Operational Support Plans, Rev. 1. Results of these reviews have been consolidated in overall planning efforts.

c. NRX operational planning was evaluated in order to define facility adequacy. Test duration studies at Test Cell "A" initiated by WANL and presented by WANL TME-279 and 340 were reviewed to establish the magnitude of modification of Test Cell "A" during CY 1963 was impractical due to (a) lead time required and (b) potential effects on the IASL and early NRX tests. This subject was discussed during the May Coordination Meeting with SNPO-C.

As a result of the above efforts, certain modifications which could be accomplished without undue influence on test operations were authorized by SNPO-C during CY 1963.

d. Preliminary studies were conducted to determine the feasibility of providing a single phase propellant feed system as required for controlling the hydrogen propellant temperature of the reactor inlet. Coordination with LASL and evaluation of the LASL mixing chamber tests were initiated. Evaluation of WANL TME 374 which described the desired characteristics of the mixing system was made. 


\section{Develop Facility Requirements}

Liaison with SNPO-C, WANL and test site organizations has been maintained to assure compatibility of proposed modifications to Test Cell "A" with the NRX test program and to assure the functional, operational, and safety adequacy of the Resctor Development Facility developed under this program.

Several major coordination meetings were held during the vear with SNPO-C, REON, WANI and IASL personnel. These meetings provided management support, program review, and technical coordination and direction for developing the requirements for and scheduling modifications of Test Cell " $A$ " for the NRX program. Pertinent meeting szhedules and topics are listed in the bibliography. Minutes of meeting at SNPO-C regarding a Review of Test Cell "A" Instrumentation, Data Reduction and Data Acquisition were published as REON Report 2703, dated 30 september 1963.

\section{Review Documents}

All appropriate $\mathbb{N R X}$ documentation and test planning data coordinated under Subtask 1.1 was subject to review by Subtask 3.6 to assess the influence of the test planning on facility capability and to provide data necessary to assess proposed facility modifications.

The results of these reviews have been coordinated and incorporated by Subtask 1.1 as applicable.

4. Assist Checkout and Activation

Drafts of various NRDS "Iest Cell "A" facility documents and operations procedures were prepared and/or released during CY 1963. The effort associated with this activity was shared by Subtasks 3.6 and 1.8 during CY 1963. Documents were prepared under the direction and cognizance of NTO management. Typical examples are:
a. $\mathrm{LH}_{2}$ Fill station, ICA
b. $\mathrm{GH}_{2}$ Fill Station, TCA
c. He Fill Station, TIA 


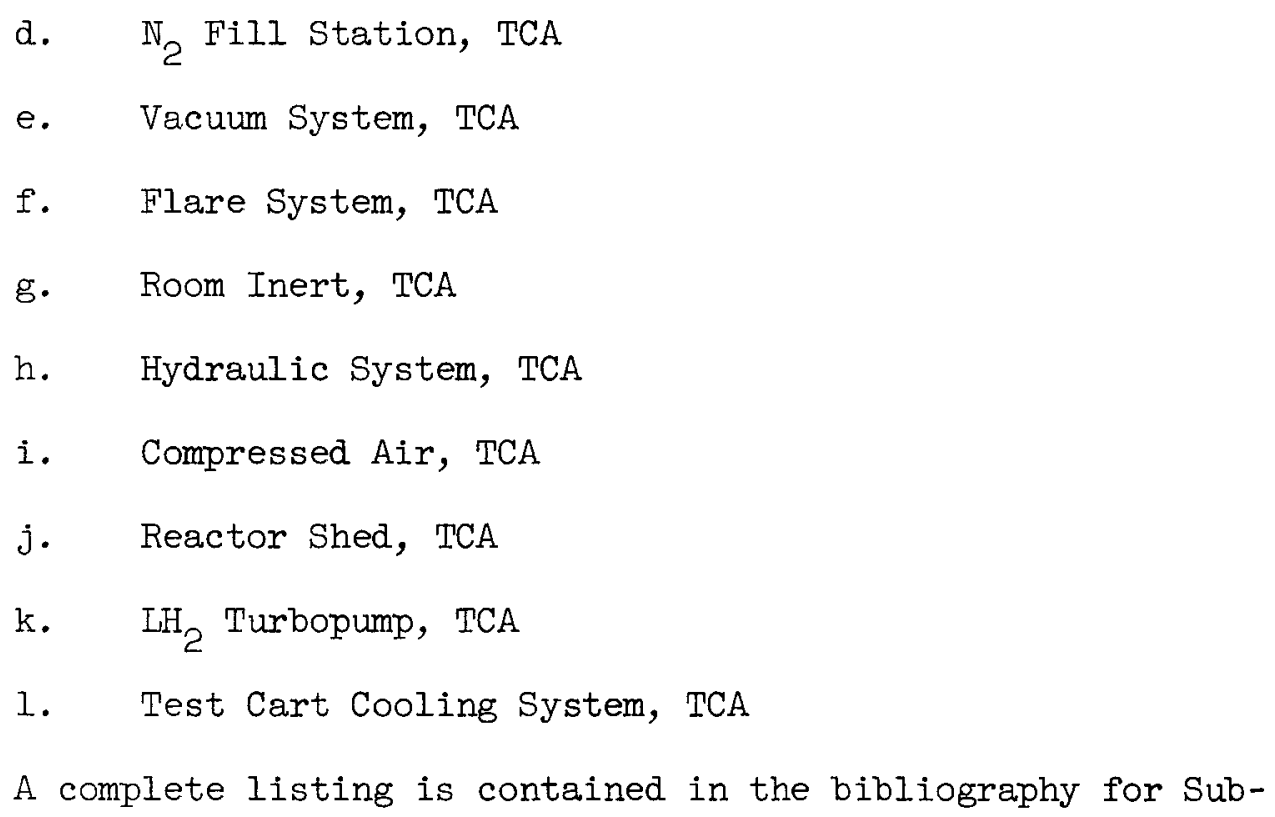

In conclusion, the efforts conducted during CY 1963 on this subtask have fulfilled the objectives of the work statement and program requirements leading toward an adequate capability for testing the NRX reactors. 


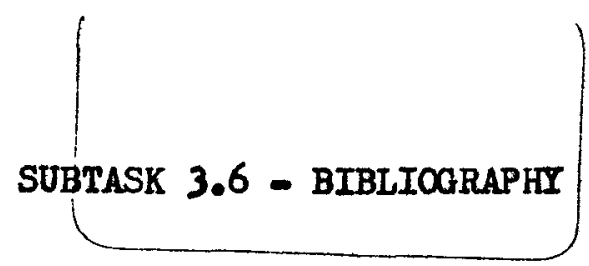

REACTOR DEVELOPMENT FACILITY

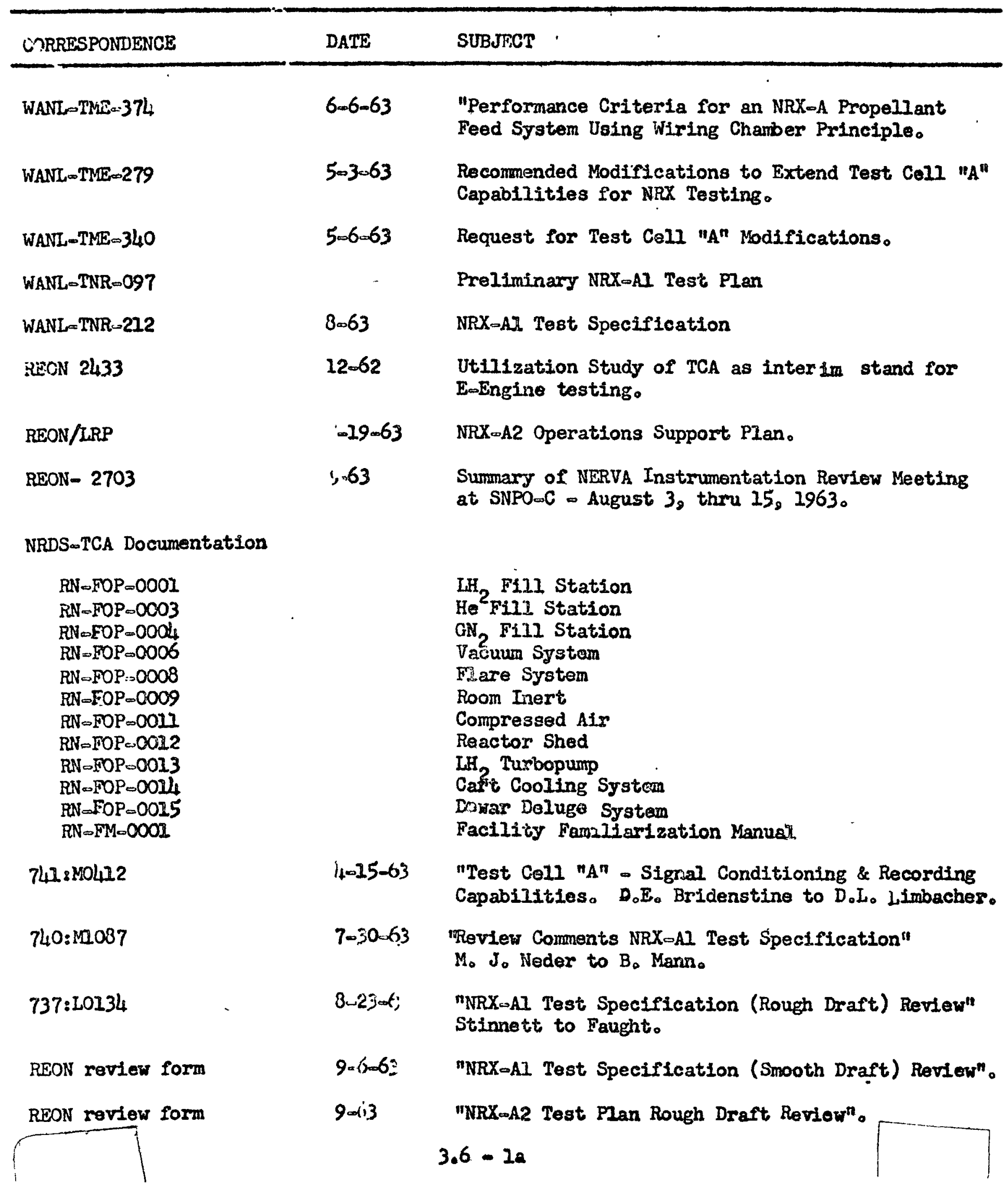




\begin{tabular}{|c|c|c|}
\hline MEETING DATE & WITI & TOPIC \\
\hline $10=25-62$ & $\begin{array}{l}\text { WANL/REON/ } \\
\text { SNPOCC }\end{array}$ & $\begin{array}{l}\text { Progress \& Status Planning fo: Test CoII "Al } \\
\text { Test Requirenents \& Durationa }\end{array}$ \\
\hline $11-29062$ & $\begin{array}{l}\mathrm{WANL} / \mathrm{REON} / \\
\mathrm{LFP} / \mathrm{SHPO} \text { - }\end{array}$ & 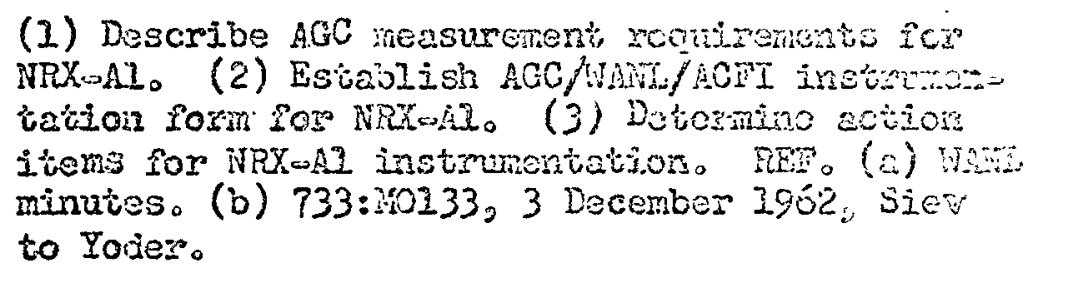 \\
\hline $3-20.033$ & 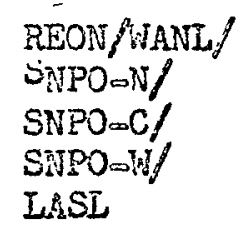 & 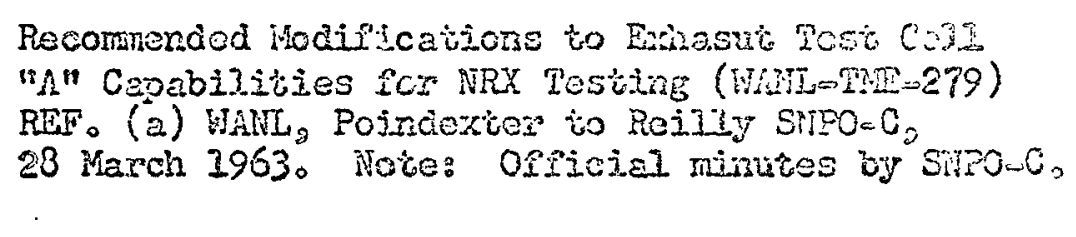 \\
\hline $3-25 \& 3-26-63$ & $\begin{array}{l}\text { REON/NARL/ } \\
\text { LRP }\end{array}$ & 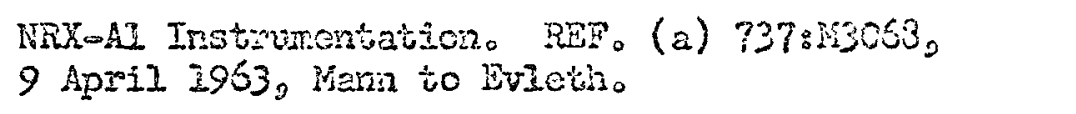 \\
\hline $40-26-53$ & $\mathrm{REON/NTO}$ & 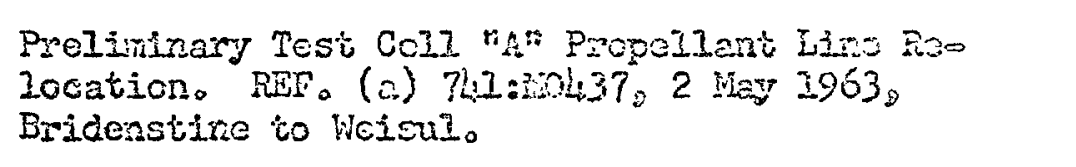 \\
\hline $5 \times 8 \& 509063$ & $\begin{array}{l}\mathrm{REON} / \mathrm{SNEO} \\
\mathrm{N}_{3} \mathrm{H}_{2} \mathrm{C} / \mathrm{A} \\
\mathrm{LASL} / \mathrm{HANL}\end{array}$ & 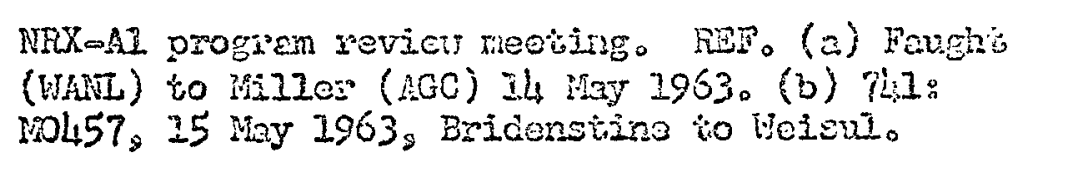 \\
\hline 9.13 to $901.5-63$ & $\begin{array}{l}\text { SWPOCC/ } \\
\text { REON/IRSL/ } \\
\text { WANL/LEWIS }\end{array}$ & 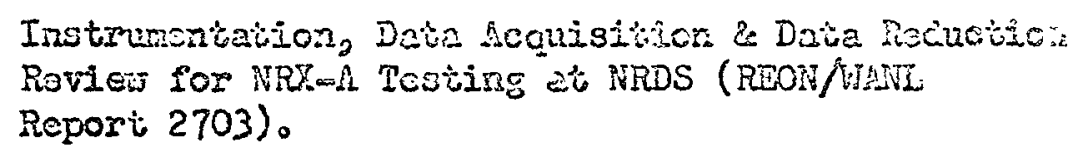 \\
\hline
\end{tabular}




\section{S/T 3.7 RADIATION EFFECTS FACILITY}

ACCOMPLISHMENTS

\begin{abstract}
$W / s$
REFERENCE

PLANNED

2-3.7(1) SUPPORT

TO SNPO-C

(a) AS REQUESTED

(b) PROVIDE INTERFACE DRAWINGS

(b) PERFORMED

(c) MAINTAIN TECH. LIAISON WITH SNPO-C (c) PERFORMED AND AENE COORDINATION ASSISTANCE
\end{abstract}

2-3.7(1) DOCUMENT (a) REVIEW AEE PRODUCED DWGS, REVIEW SPECS \& REPORTS AS REQUIRED 2-3.7(1) ACTIVATION (a) PLANNING ASSIST AS REQUIRED IN PREP. OF ACTIVATION AND C/O OF REF

SPECIAL REQUEST (a) SNPO-C 5-22-63

PREPARE DATA ACQUISITION REQUIREMENTS DOCUMENT AND ROM COST STUDY FOR REF (a) PERFORMED

(a) PERFORMED

(a) COMPLETED
EVIDENCE OF COMPLETION

(a) L741:0188 DTD 5-15-63 L741:0247 DTD 7-11-63 L741:0250 DTD 7-11-63 L741:0274 DTD 8-7-63

(b) AGC DWG. \#700269

(c) L740:0046 OTD 5-2-63 TWX 741:162 DTD 9-10-63 SEE BIBLIOGRAPHY TECH MEETINGS

(a) L741:0238 DTD 7-2-63 L741:0306 DTD 9-26-63 L741: 0188 DTD 5-15-63 


\section{Purpose and Objective}

1. Support to SNPO-C

a. "Provide Updated Requirements as Requested"

These requirements were submitted to SNPO-C in the fol-

lowing documents:

L741:0188, dated 15 May 1963, "REON comments to SNPO-C

document 'revised technical and test objectives for NARF'"

This letter made corrections to and stated additional

requirements to those requirements established by SNPO-C for the initial

direction of the A\&E.

I741:0247, dated 11 June 1963, "Propellant feed system operating temperature"

This letter established the pump and turbine discharge temperature requirements to be reflected in the facility.

L741:0247, dated 11 July 1963, "REON comments to SNPO-C

ref redirection"

SNPO-C directed that the facility would be sized for a 10 minute run capability, in lieu of the 20 minute run capability.

REON's letter indicated that no questionable or adverse test results would be produced as the result of this redirection.

L741:0250, dated $11 \mathrm{July} 1963$, "Facility minimum startup requirements for PFS tests at NARF"

This letter established the flow, pressure and temperature requirements for pump and turbine inlets based on a 20 second startup.

L741:0274, dated 7 August 1963, "REON non-concurrence of SNPO-C proposal for horizontal mounting of PFS at NARF"

This letter stated that test results would be inconclusive if the PFS was mounted horizontally for tests at NARF. 
b. "Provide Interface Drawings"

AGC Drawing No. 700296 "Preliminary Propellant Feed System Interface Control Drawing"

This drawing established the location of the hardware, the primary dimensions, and the interface location of all lines and harnesses that will be part of the test article.

c. "Maintain Technical Liaison with SNPO-C and A\&F Coordination Assistance"

Five technical coordination meetings were attended as requested by SNPO-C for direct communication with General Dynamics/Fort Worth, and Kellogg/EG\&G. (See bibliography for summary of technical coordination meetings.) Examples of this coordination are:

L741:0046, dated 2 May 1963, "REON procedure for processing Task 3.7 (Ref) A\&E information requests and drawing review"

This procedure established the communication channels to be followed and the manner in which information would be submitted and drawing reviews conducted. Basically all communication to and from the A\&E would be through SNPO-C.

TWX 741:162, dated 10 September 1963, "REON answers to M. W. Kellogg questions presented in Letter No. 13"

This TWX supplied information concerning the following:

(1) Turbine backpressure

(2) Turbine inlet temperature for full run and short periods

(3) $\mathrm{LH}_{2}$ inlet flow rate variances and rate of variance

(4) Pump suction control response

(5) Operating time for the turbine inlet scram valve.

2. Document Review

a. "Review A\&E Produced Drawings, Specifications and Reports as Required" 
Two packages of the M. W. Kellogg Company ref design material composed of drawings, reports, documents and specifications were received from SNPO-C by REON during CY 1963.

(1) Package 1 identified as Job 6029, No. 2425 consisted of:

(a) Preliminary process schematic

(b) Process description

(c) Major component specification chart

REON's review comments and recommendation were presented at a review meeting held at SNPO-C in June and became part of the minutes of that meeting. (Ref: L741:0238, dated 2 JuIy 1963)

(2) Package No. 2, "Process Specification (for approval) NARF Modification Program, Fort Worth, Texas," Job 6020, dated 16 August 1963.

REON's review comments and recommendations of this package were submitted to SNPO-C as enclosures to L741:0366, dated 26 September 1963.

\section{Activation Planning}

a. "Assist as Required in Preparation of Activation and Checkout of Ref"

The facility design progress did not warrant initiation of activation planning during CY 1963; however, informal discussion with SNPO-C regarding operational responsibilities and internal REON planning has been accomplished.

4. Special Requests

a. "Prepare Data Acquisition Requirements Document and ROM Cost Study for Ref"

L741:0270, dated 5 August 1963, "Preliminary Data Acquisition and Control System Requirements" 
REON was requested by SNPO-C to prepare the data acquisition and control system requirements for PFS testing at NARF and to include a ROM cost estimate for the design, fabrication, procurement, installation, and checkout of such a system.

The data acquisition system, presented in REON Report 2319A, dated 1 October 1962, was based on the understanding that certain data acquisition capability existed at NARF which would require only minor supplemental equipment for PFS testing.

Since that time, we have been informed that this capability does not exist which required that our original requirements had to be expanded.

The data acquisition system as described consists of 165 channels to be recorded on analog tape, digital, oscillograph and strip chart equipment presents the direction that the NARF DAS shall be comparable to the LRP DAS which is to be employed for non-nuclear PFS development tests.

The control system described in L741:0270, also stated the functions of the test article and the facility that will be controlled by the PFS control console and the manner in which this control will be accomplished.

Conclusion

In conclusion, the efforts completed by REON under this subtask have met all of the defined SNPO-C requests and have aided materially in timely SNPO-C direction of the Ref program. 


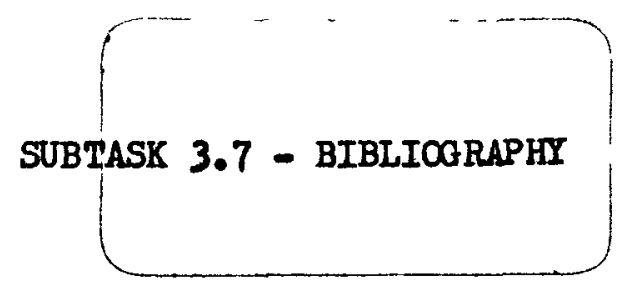

RADIATION EFFECTS FACIITTY

Correspondence to SNPO-C - 2WX

TwX No. Date

From

To

Subject

$741: 032 \quad 4-26-63$

WD Stinnett

KW Schroeder

Review Comments Submittal Date

741:055 5-31-63 WD StInnett RW Schroeder Target Date DA Rtquirements

741:058 6-5-63 WD Stinnett RW Schroeder Submittal Dates

741:070 6-14-63 IE White JB Stauffer Telecon Confirmation

741:079 6-21-63 JR Campbell JB Stauffer Telecon Confirmation

741:081 6-24-63 JR Campbell JB Stauffer Telecon Confizmation

741:089 7-1-63 WD Stinnett $\quad$ WW Schroeder Interface Drawing Date

741:090 7-1-63 JR Campbell JB Stauffer Telecon Confirmation

741:122 7-31-63 JR Campbell JB Stauffer Telecon Confirmition

741:140 8-23-63 JR Campbell JE Stauffer Telecon Confirmation

$741: 156$ 8-30-63 HJ Rosso JB Stauffer Telecon Confirmation

741:162 9-10-63 WD Stinnett $K W$ Schroeder Answers to Kellogs Questions 


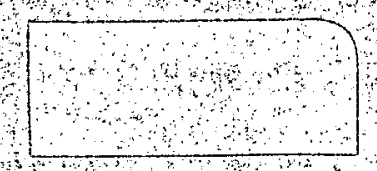

Correspondence from SNPO-C - TWX

TwX No. Date from wo subject

5-16-63 JB Stauffer JR Campbe11 Telecon Conflrmation

$101,2,6-10-63$, WW Schoeder WC House

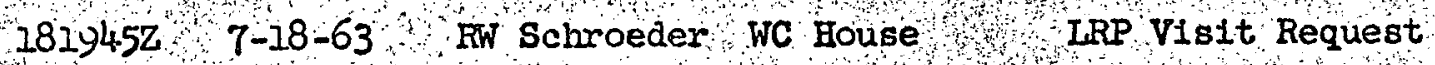
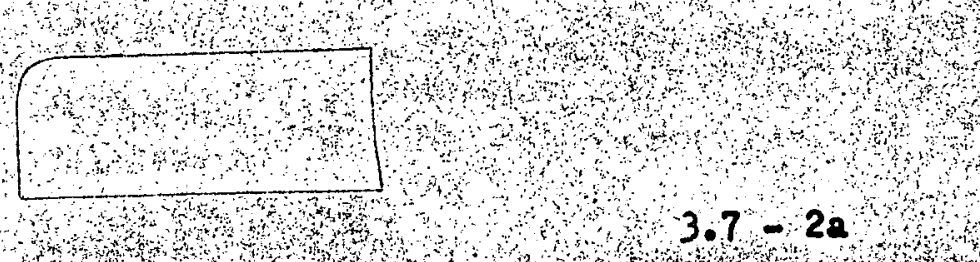

$$
3.7-22
$$


Correspondence to SNPO-C - IEITIERS

Ietter

Wumber Date From to

L740:0046 $5-2-63$, WC House

KW Schroeder REoN Operating Procedure

$1741.0181,5-10-63$ WC House

IW Schrôder

Telecon Conflrmation

I $741: 0188$ 5-15-63 WC House

KW Schroeder

Review Comments SNPO-C Document

L741:0191 5-20-63 WC House

RW Schroeder

Telecon Confirmation

I741:0192 5-20-63 WC House

HW Schroeder

Telecon Conflimation

$I_{1}^{2}+10193,5-20-63$ WC House

RT Schroeder

Telecon Conflrmation

LF4:0197 5-22-63 WC House

FW Schroeder

Telecon Conflimation

$1741: 0204 \quad 5-29-63$ WC House

HW Schroeder

Telecon Confirmation

L741:0214 $6-11-63$ WC House

RW Schroeder

Faclilty Operating Temperatures

L741:0215 6-11-63 WC House

RW Schroeder

Telecon Confirmation

I741:0247, $7-17-63$, WC House

RW Schroeder

Coments to SNPO-C Redirection

I741:0222 $6-14-63$, WC House

RW Schroeder

Telecon Conflrmation

I74I:0250 $7-11-63$ WC House

RW Schroeder

Faclilty startup Requirements

I741:0263, $8-2-63$ WC House

KW Schroeder

Cover Letter Interface Drawing

IT41:0270 $8-5-63$ WC House

Eir schroeder

Data Acquisition Requirements

$1741: 0274,8-7-63$, WC House

$\mathrm{I} 741: 0306$ \% $9-26-63$ wC House

KW Schroeder

Non-concurrence Hor1zontal Ifounting

En Schroeder

Review Comments to Design Material 

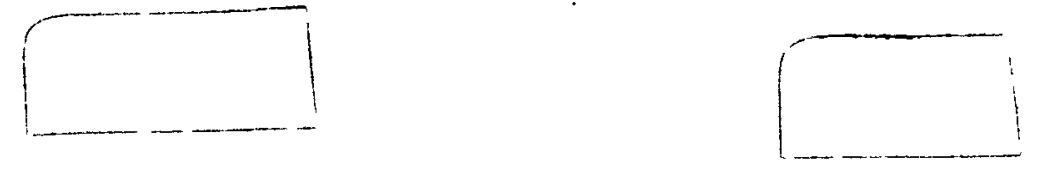

CORRESPONDEHCS FROM SMPO-C

\begin{tabular}{|c|c|c|c|}
\hline IETPER NO. & DATEE & SUBJECT & EROM \\
\hline FDG:JBS & 8 May & Information Requested by AdeE & RWSchroeder - WCHouse \\
\hline \multirow[t]{4}{*}{ FDG:JBS } & 10 June & Transmittal Design Material & JBSteuffer - JRCampbell \\
\hline & $1 \mathrm{Ju} I \mathrm{y}$ & SIIPO-C Minutes of Meeting & JBStauffer - JRCampbell \\
\hline & 21 Aug & Transmittal of Design Materlal & JBStauffer - JRCampbell \\
\hline & 29 Aug & $\begin{array}{l}\text { Kellogg Transmittal of Design } \\
\text { Naterial }\end{array}$ & DAMemegaz - Jicarton \\
\hline
\end{tabular}


TEGHWICAL MEETINGS

MEETING NO. 1

24 Apr11 - REON, BNPO-C, M. W. Kellogg, GD/FW Meeting at SHPO-C, Ref: $1740: 0045,5-3-63$

This meeting established the commalcation channels to be followed In the interchange of information concerning the creation of the cryogenics facility at MARF under Task 3.7. Basically, this sgreement sald that all information will be transmitted through SNPO-C. All comonication directed at REON would be through the 3.7 Task Manager. This agreement did not alter the comminication channels previously established for other tasks, such as 2.2 and 1.9, but provided for the 3.7 Task Manager to be informed of activities in these tasks.

During this meeting, REON received coples of the SNPO-C document "Revised Technical and Test Objectives for MARF," which is the basis for the M. W. Kellogg design of the facility.

METING MO. 2

May 22, 23 - REON, SNPO-C, M. H. Kellogg, GD/FW, EG\&G, and IRP Meeting at Azusa, Ref: 1741:0211

a. REON paesented corrections, corments to SNPO-C document, "Revised Mechnical and Test Objectives for MARF。"

b. SNPO-C made the following design schedule statement, "PreIiminary design completed approximately 1 September 1963 - Final design completed approximately I November 1963."

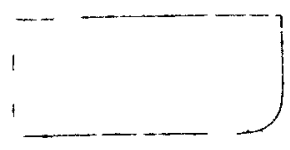

$$
3.7-5 a
$$


1

c. REON went on record with the following statement, to which there hasn't been an acceptance or denial by SRPO-C. "Because of the complexity of the tests to be performed upon the NkiRV Propellant Feed Bystem at MART, REON w1Il supply key technical pereonnel for activation and checkout of the facility and to install hook-up and checkout prior to test and test the Propellant Feed System."

d. Basic ground rules for particlpant responsibilities were established for the facility, test article, Data Acquisition and Control Systems.

e. Basic facility operating requirements were established。 MEEIIITC $\mathrm{NO}_{0} 3$

June 18, 19, 1963 - REON, SNPO-C, GD/FW, M. W. Kellogg, EGrG, Levis Iab., IRP Meetings at SHPO-C (Ref. (741:0238)

Purpose: Reviev of Kelloge process flow diagram.

a. SWPO-C made the following redirection of REF.

(1) Facility to be sized for a 10-minute run capability.

(2) Facility startup requirements to be the same as ASTR but not to exceed 20 seconds.

(3) NPSP need not be held to the steady state figure during startup and shutajown transients.

b. KEON requested by SIDO-C to provide facility startup and shutdown curves.

c. Kellogg directed to proceed with design based on 10-minute run time and sizing "Level Pot"/"Run Tank" at minimum required to meet PFS requirements. The "Run Tank" is a large area in the Iine directly upstream

$$
3.7-62
$$


of the inlet to the tank shut-off valve, used to stabilize flow and pressure prior to entering the pump.

MEEIPIIG $\mathrm{NO}_{0} 4$

June 26, 1963. - REON, IRP, M. W. Kellogg, PFS Interface Meeting at IRP (Ref. IT41:0243)。

The following agreements were reached:

a. All ACC supplied lines, harnesses, etc. will terminate at a point adjacent to the thrust structure attachment.

b. All disconnects will be in the same plane and emerge in the same general direction.

c. AGC will provide both halves of all disconnects for PFS to test stand.

d. Kellogg to proceed with design following these ground rules.

MEREIIIIG HO. 5

July 23, 24 - REON, SNPO-C, M.W. Kellogg, GD/FW, IRP Meeting at IRP, (Rer. Ir741:0269).

REON requested by SUPO-C to provide answers to the following:

a. In conjunction with the staxtup and shutdown curves presented by REON it will be necessary to know the rate of change and magnitude of change required during a test run of the pump inlet pressure and flow. (answered 9-10-63 - TWX 741:162)

b. What is the maximum time allowed for cutoff of turibine inlet gas Ilov to shutdown the TPA in an overspeed condition. (answered 7-11-63(571:0250)

$$
3.7-7 a
$$


c. The present state of the art of hardware design and materials available will not allow inlet conditions of hot gas to the turbine above 1850\% $\mathrm{F}$. REON's requirement of $2000^{\circ} \mathrm{F}$ cannot be attained at this time. (answered 9-10-63- $75 \times$ x $741: 162$ )

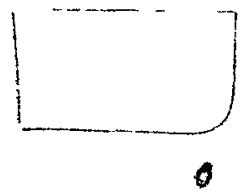




\section{S/T 3.8 NRDS RAD MATL COMPLEX}

\section{HANDLING, DECON. \& STORAGE COMPLEX ACCOMPLISHMENTS}

$W / s$

REFERENCE

2-3.8 (1) SUPPORT (a) PROVIDE AS REQUIRED UPDATED

TO SNPO-C

(b) MAINTAIN TECH LIAISON WITH

SNPO-C \& OTHERS

(c) PERFORM SPECIAL STUDIES AS REQUESTED

2-3.8(2) DESIGN (a) PROVIDE CRITERIA, PLANNING CRITERIA DATA AND ROM COSTS FOR REF FACILITIES

2-3.8 (3) DOCUMENT (a) PERFORM REVIEWS OF DRAWINGS, REVIEW SPECS, REPORTS AS REQUIRED SPECIAL REQUEST (a) CONDUCT REEVALUATION OF FACILITY SITING

SNPO-C 8-1-63

ACTUAL

(a) PERFORMED

(b) PERFORMED

(c) PERFORMED

(a) COMPLETED

(a) PERFORMED

(a) COMPLETED
EVIDENCE OF COMPLETION

(a) AGC REPORT *2584 DTD 6-17-63

(b) SEE BIBLIOGRAPHY TOTAL IZI COMMUNICATIONS

(c) SEE BIBLIOGRAPHY (MEETINGS)

(a) AGC REPORT * 2592 DTD 6-25-63 AGC REPORT * 2603 DTD 6-25-63 AGC REPORT \#2603 (REV) DTD 8-22-63

(a) L741:0308 DTD 9-13-63 MINUTES OF TECH MEETING *6 8-23-63 
Purpose and Objective

1. Support to SNPO-C

a. Updated Requirements

REON delineated NERVA operational, functional, and safety requirements for the radioactive materials handling, decontamination and storage facility capability at NRDS in REON Report No. 2584. This report was informally submitted on 5 April 1963 at Meeting No. 1 and, following revision in accordance with SNPO-C comments, was published on 17 June 1963 (Ref: Bibliography).

\section{b. Technical Liaison}

Technical liaison was maintained with SNPO-C, subcontractors, NTO and related subtasks to assure the functional, operational, and safety adequacy of the design criteria developed under the subtask. The effort involved six technical coordination meetings with SNPO-C and produced 48 letters, 37 TWXs, and more than 30 telecons (Ref: Bibliography).

\section{c. Special Studies}

During the development of the design criteria and conceptual designs, special studies were conducted and reported in technical meetings. Typical of these studies are listed below (see Bibliography).

(1) Evaluation of decontamination pad location (741:0219 dated 14 June 1963)

(2) Facilities siting studies (741:0194 dated 21 May 1963)

(3) Cost study of three spent fuel storage concepts (741:0219 dated 14 June 1963)

(4) Radiation analysis of spent fuel storage concept (741:0223 dated 14 June 1963) 


\section{Design Criteria}

REON was requested to prepare design criteria for the radioactive materials complex facilities and the engine transport system maintenance building at Meeting No. 1, held in Cleveland on 5 April 1963 (L741:0155 dated 23 April 1963).

Reports No. 2592 and 2603 were submitted on 25 June 1963 for the above facilities in full satisfaction of this milestone.

Report No. 2603, ETSMB design criteria, was subsequently revised in accordance with SNPO-C comments and published on 22 August 1963. As a result of SNPO-C direction, associated with the NRX feasibility study, this document is to be revised during CY 1964 to incorporate NRX requirements.

Final publication of Report No. 2592 was deferred to CY 1964 by SNPO-C pending further direction.

3. Document Review

No design review was required during the contract year.

4. Special Requests

Siting study

A siting study was undertaken in response to the SNPO-C request of I August 1963. This effort involved site inspection and the development of three new drawings showing alternate facility layouts and plot plans.

The results of this study were presented to SNPO-C at Technical Meeting No. 6 and by letter L741:0308 dated 13 September 1963. After this meeting a meeting was called at SNPO-W for resolution of the site location. As a result of this meeting an alternate site location proposed by SNPO-C/REON was selected.

Conclusion

In conclusion, the effort expended by $R E O N$ on Subtask 3.8 has resulted in complete fulfillment of all requirements and requests in a manner which provided required information for A\&E services. The siting relocation for the 
RMHDS and the NRX feasibility study will require some further revision of the criteria generated. 
IIRDS RADIOACTIVE ILATERIAL COIPLEX

Correspondence to SIPO-C

Correspondence

TWX

Letter

THXX

TVIX

Lotter

Letter

Letter

Letter

Letter

Letter

Letter

Letter

Letter

Letter

TWTX

Letter
Date 30 April 63

10 May 1963

15 ilay 1963

15 May 1963

15 llay 1963

7 June 1963

7 June 1963

7 June 1963

11 June 1963

1 July 1963

6 Aug 1963

9 Aug 2963

9 Aug 1963

3 Sept 1963

17 Sept 1963

27 Sept 1963
Subject

Agenda for Meeting No. 2 Schroeder to L.E. White

Data on Vitro Spent Fuel Stora, e Concept Brookshire to House

Agenda for Meeting No. 3 Schroeder to House

Comments on Preliminary Operational Req. to Report Brookshire to House

Comments on Minutes of Heeting Ho. 2

Comments on Minutes of Heeting lloo 3 Brookshire to House

Spent Fuel Storage Concept and Agenda Meeting No. \& Brookshire to House

ETSMB to remain in Task 3.8 Schroeder to Ifouse

Approval of linutes of leeting No. 4 Brookshire to House

ETSMR to remain in Tash 3.8 Schroeder to House

Supplying IASL Comments on Report 2592 Renas to White

Hot Engine Hold Design Criteria Schroeder to House

Relocation of Storage and Disposal Facilities Schroder to llouse

Approval llinutes of Meeting No. 5 \& Agenda lleeting Ho. 6 Brookshire to House

Meeting. Notification Vissing to House

Minutes of Washington Meeting Vissing to House

$$
3.8-1 a
$$

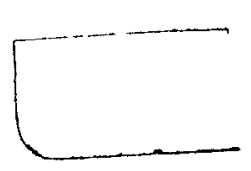



TWX 74I:094

$\operatorname{TVI} 741: 110$

TVIX 741:117

2741:0259

L741:0261

$\operatorname{TrX} 741: 125$

L741:0279

I74]:0280

I765:599

TWX 74]:135

$1765: 605$

TWX $741: 148$

TwX 741:151

I74I:0300

L741:0301

TIX $741: 152$

TIX 741:149

I741:0303

I74]:0308

[74]:0307

TWX 741:178

$2741: 310$
10 July 1963

16 July 1963

26 July 1963

29 July 1963

29 July 1963

12 Aug 1963

15 Aug 1963

15 Aug 1963

27 Aug 1963

23 Aug 1963

27 Aug 1963

27 Aug 1963

28 Aug 1963

29 Aug 1963

29 Aug 1963

30 Aug 1963

3 Sept 1963

6 Sept 1963

13 Sept 1963

20 Sept 1963

23 Sept 1963

26 Sept 1963
Telecon SNPO-C review comments on Reports 2592 \& 2603 Stinnett to Schroeder

Telecon-Date for Technical Meeting Stinnett to Schroeder

Schedule for Publication of Final Report 2603 Stinnett to Schroeder

Action Item Summary Report House to Schroeder

Minutes of Meeting No. 5 House to Schroeder

Telecon-Content o: Report 2603 Stinnett to Schroeder

Action Item Summary Report House to Schroeder

Approved Minutes of Meeting No. 5 House to Schroeder

Transmittal of Final Report 2603 Ryland to Corringto

Agenda for Mceting No. 6 Stinnett to Schroeder

Transmittal of Additional copies of Report 2603 Ryland to Corrington

Use of Report 2603 Stinnett to Schroeder

Telecon-SNPO-C data on fence requirements Stinnett to Schroeder

Minutes of Meeting Io. 6 Stinnett to Schroeder

Action Item Summary Report Stinnett to Schroeder

Telecon-Schedule for siting evaluation StInnett to Schroeder

Telecon-Schedules and criteria publication Stinnett to Schroeder

Transmittal of ACFI Drowing Stinnett to Schroeder

Siting evaluation Stinnott to Corrington

Action Item Summary Report Stinnett to Schroeder

Telecon-SIPP-C approval of minutes of meeting Hoo 6 Stinnett to Schroeder

Approved Minutes of Meeting No. 6 Stinnett to Schroe

$$
3.8-3 a
$$

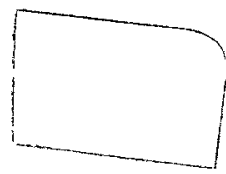



RDS RADIOACTIVE MATHRIAL COMPIEX

Correspondence WAML to REON

Correspondence Date

Subject

\begin{tabular}{|c|c|c|}
\hline TME-245 & 11 Jan 63 & Initial Operational Requirements \\
\hline$T M-287$ & 4 IIarch 63 & Operational Requirements Faught to 111 ller \\
\hline $\mathrm{T} \times 2288$ & 13 May 63 & Upgrading Tite-287 Faught to Iniller \\
\hline TrXX 2733 & 3 June 63 & Transmittal date of cooling Reqts. Faugin to lililes. \\
\hline GSE 117 & 11 June 63 & Spent Tuel Cooling Faught to Miller \\
\hline GSE 121 & 12 June 63 & KTUI Dags Information Faught to Miller \\
\hline "GSE 151 & 9 July 63 & Upgrade Operational Reqts. Faught to Miller \\
\hline GSE 185 & 9 Aug 63 & Reactor Cooling Reqts Faught to Ifiller \\
\hline TTX 4387 & 19 Aug 63 & $\begin{array}{l}\text { Telecon Reactor Monitoring is Cooling Reqts. } \\
\text { Faught to liiller }\end{array}$ \\
\hline$T \times 4507$ & 22 Aug 63 & $\begin{array}{l}\text { Telecon Meeting date reactor monitoring and cooling } \\
\text { Faught to Miller }\end{array}$ \\
\hline $\operatorname{TWX} 5248$ & 26 Aug 63 & Telecon Spent Fuel Cooling Faught to Miller \\
\hline
\end{tabular}




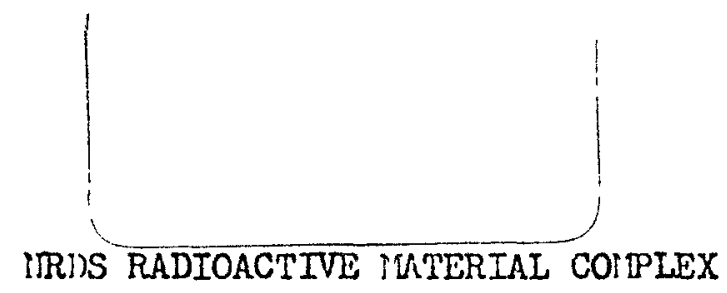

Correspondence REON to VAII,

\begin{tabular}{|c|c|c|}
\hline Correspondence & Date & Subject \\
\hline I $760: 2061$ & 27 INov 62 & Preliminary Oporational Requirements VRuiller \\
\hline$L 760: 2369$ & $4 \operatorname{Jan} 63$ & Operational Requirements VRililler \\
\hline TWX 583 & 14 Feb 63 & TME-245; Deficiencies Stinnett to $H_{0}$ Johnson \\
\hline L740:0043 & $20 \Gamma \mathrm{eb} 63$ & Supnlving Report Outline Ihite to Johnson \\
\hline TWX $747: 040$ & $8 \mathrm{May} 63$ & Comment on Prelim. Op. Reqts Stinnett to Faught \\
\hline$T W X 741=048$ & 22 May 63 & Spent Fuel Cooling leqts Stinnett to Faught \\
\hline$T W X 741: 054$ & 31 May 63 & Request KTVI Test Car Dwg. Stinnett to Faught \\
\hline $\operatorname{TwX} 741: 067$ & 12 June 63 & Telecon Spent Fuel Storage Stinnett to Faught \\
\hline L760: & JuIy 63 & Review Reports 259 \&2603 Miller to Faught \\
\hline $\operatorname{TWX} 741: 129$ & 31 JuIy 63 & Telecon Engine Cooling Reqts Stinnett to Faught \\
\hline$T H X 741: 124$ & 7 Aug 63 & Telecon Reacuor Cooling Reqis Stinnett to Faught \\
\hline TWX $760: 4283$ & 8 Aug 63 & Spent Fuel Cooling Ililler to Faught \\
\hline THX $741: 126$ & 8 Aug 63 & Telecon Reactor llanitory Requs Stinnett to Fau, ht \\
\hline$L 760: 4292$ & 9 Aug 63. & Transmitt Report 2584 Miller to Taught \\
\hline $\operatorname{Mx} 741: 136$ & 26 Aug 63 & Telecon Spent Fuel Cooling Stinnatt to Faught. \\
\hline$T / X 741: 250$ & 28 Aug 63 & Telecon Spent 'uel Cooling Stinnett to Faught \\
\hline TWX 741:167 & $12 S_{3}$ pt 63 & $\begin{array}{l}\text { Telecon Spent Puel Cooling ie Reactor lionitory } \\
\text { Stinnett to Faught }\end{array}$ \\
\hline TIX $741: 179$ & $2 l_{i}$ Sept 63 & $\begin{array}{l}\text { Telecon Spend Fuel Cooling \& Heactor Monitory } \\
\text { Stinnett to Faught }\end{array}$ \\
\hline
\end{tabular}




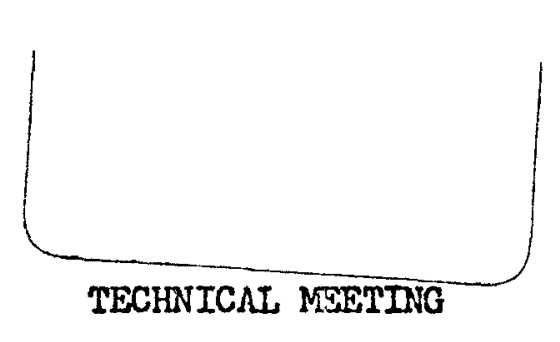

SURMARY

Technical Meeting No. I was held in Cleveland on 5 April 1963 to define the SIPO-C requirements for RFON technical assistance on NERVA Subtask 3.8, IRDS, Radioactive Materlals Handling, Dacontamination and Storago Complex.

This meeting concluded that REON would be responsible for design criteria for the subtask facilities, as well as the operational requirements. (Reference minutes of moeting L741:0155, dated 23 April 1963)

Letter FN $63002 B$, dated 17 April 1963, G. L. Ryland to R. W. Schroeder, presented the cost estimates for this change of scope and problem areas to be resolved by SNPO-C during the development of the criteria.

Technical Meoting No. 2 was held in Azuse on $2-3$ May 1963 to establish the management procedures to be used during the development of the design criteria and to resolve the proglem areas presented in letter RN-63002B. These items were satisfactorily concluded by this meeting. Early siting studies and facilities concepts were presented by REON. (Reference minutes of meeting 174180194 , dated 21 ilay 1963)

Technical Neoting No. 3 was held in Clevoland on 16 May 1963 to review rtho status of the design criteria development and to resolve outstanding problems.

REON presented an evaluation of locations for the decontamination pad and it was concluded that pad would be retalied north of the E-PMD Building and any additional pad requiremerts would be provided at the Decontanination Facility。 
REON also presented a preliminary cost evaluation of three concepts of storing spent fuel.

All outstanding action items were satisfactorily concluded. (Reference minutes of meeting I7L1:0219, dated Ih June 1963)

Technical Neeting No. 4 was held in Azusa on 28 - 29 May 1963 to revlew the atatus and schedule of the design criteria and the facility sites and concepts developed by REON and the operational, radiation, and cost considerations associated with the selection of those sites and concepts.

No major departures from SIPPO-C concepts were identified and no new direction by SIIPO-C was consldered nocessary at that time. All outstanding action items were satisfactorily resolved. (Reference minutes of moeting 174180223, dated 14 June 1963)

Technical Meeting No. 5 was held in Cleveland on 19 July 1963 to review the SNPO-C comnents and Preliminary Report No. 2592, Radioactive Materlals Handling, Decontamination, and Storage Complex Design Concept and Criteria, and Preliminary Report No. 2603, Engine Transport System Maintenance Building Design Criteria, which had been submitted to SNPO-C on 25 July 1963 in satisfaction of the 1 July 1963 milestone.

No major technical changes were recomendod excopt to the Hot Engine Hold Facility. Re-evaluation of the engine monitoring and cooling requirements were requested by SNPO-C.

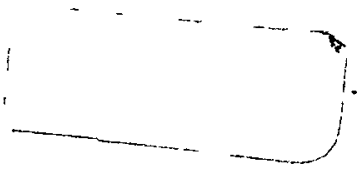

$$
3.8-8 a
$$


SNPO-C directod that Report No. 2592 not be issued untll after two other SNPO meetings and release by SNPO-C. (Reference minutes of meeting I 74I:0280 dated 15 August 1963)

Technical Meeting No. 6 was held in Azusa on 22 -223 Augugt 1963 to review new siting arrangements of three facilities that were propared in response to the SNPONC request of 1 August 1963 and comments on Report No. 2592 supplied by LASL。

The LASL comments were reviewed and no real conflicts with the design criterla were determined; however, REON did not concur in the relocation of facilities as indicated by SNPO-C and planned to request further review and evaluation of the siting. (Reference minutes of meeting $7741: 0310$, dated 26 September 1963)

SNPO held a meeting at AEC, Germantown, Maryland, on 19 September 1963, with REON representod. This neeting was to conclude SIPO outstanding action items including siting of the radioactive materials facilities, However, no decision on sliting was reached. SNPO-N was to re-evaluace the siting and and make a reconmendation by 25 September 1963.
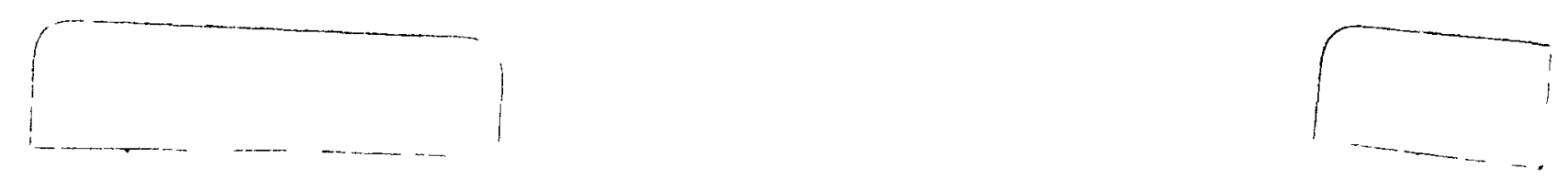

$$
3.8-9 a
$$




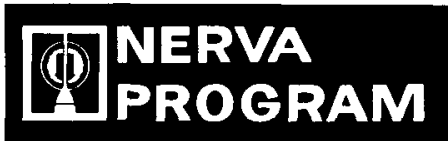

SCHEDULES AND MILESTONES

CONTRACT YEAR 1963

TASK ITEM 3.8

绿

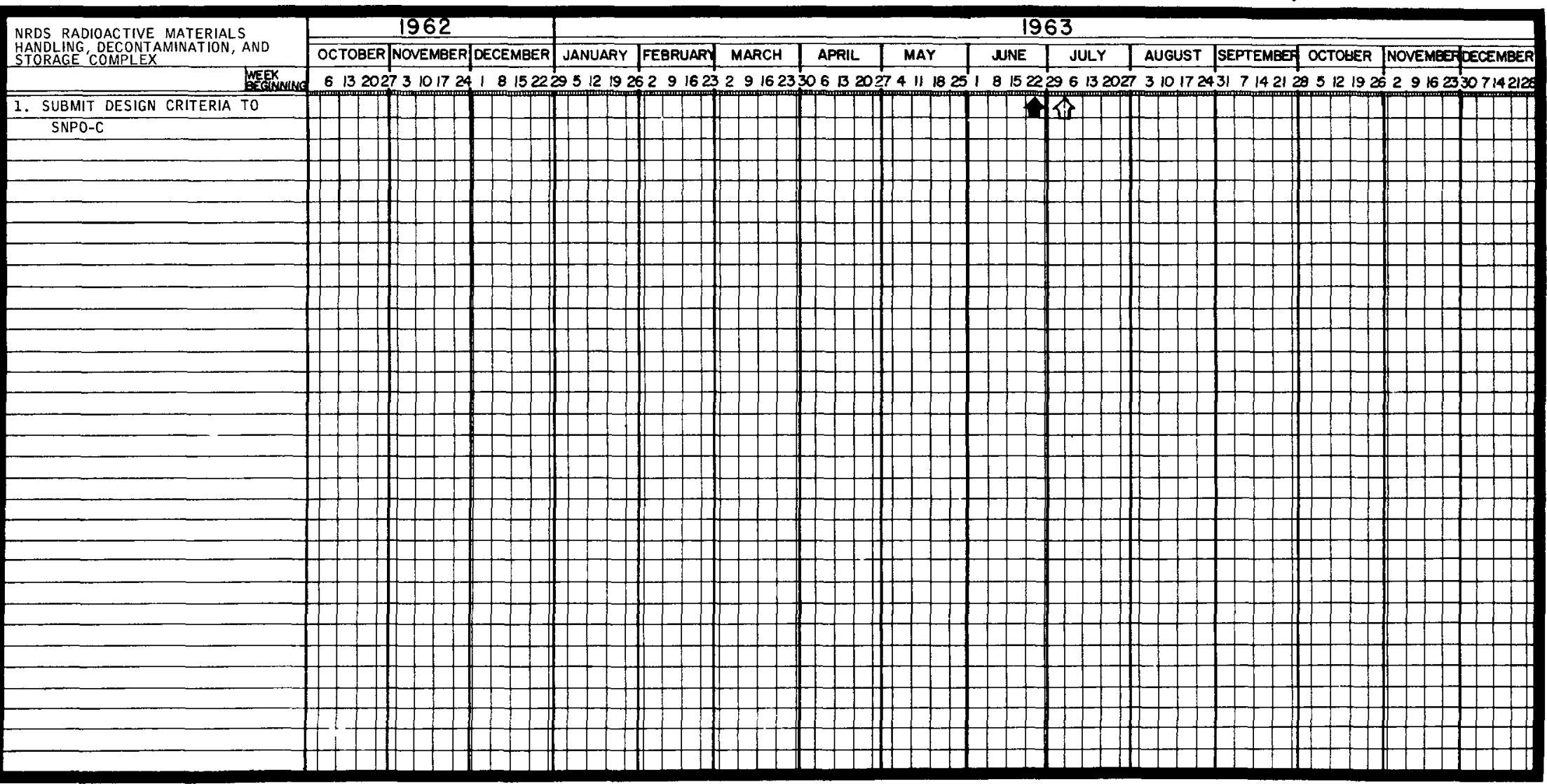

DATE:

\ SCHEDULED MiLESTONE

- MILESTONE ACHIEVEMENT $\diamond$ RESCHEDULED MILESTONE

RESCHEDULED MILESTONE ACHIEVEMENT
RESCHEDULED TO CY 64
RE(P) 


\section{S/T 3.9 RIFT STAGE DEVELOPMENT FACILTIES}

ACCOMPLISHMENTS

$w / s$

REFERENCE

2-3.9(1) SUPPORT TO SNPO-C

$$
\text { PLANNED }
$$

(a) MAINTAIN TECH LIAISON WITH RIFT CONTRACTORS

(b) PROVIDE FACILITY CRITERIA AS REQUESTED
ACTUAL

(a) PERFORMED

(b) PERFORMED
EVIDENCE OF COMPLETION

L740:0177 DTD 11-12-62 MINUTES OF NVPO MTG. (HUNTSVILLE) DTD I1-15-62 
Purpose and Objective

1. Support to SNPO-C

a. Provide Facility Criteria as Requested

(1) The dissemination of available NERVA information and data to NVPO personnel was made through the distribution of REON generated reports pertaining to ETS-1 and ETS-2, etc.

b. Maintain Technical Liaison and RIFT Contractors

(1) Liaison and coordinating meetings were conducted with RIFT contractors.

An informal meeting held in October 1962 with representatives of Lockheed was devoted to a discussion of ground support system interfaces in the RIFT test area.

Representatives of REON attended the 5 October 1962 meeting of the GSE subgroup of the nuclear engine interface working group. An initial list was prepared of GSE required to support nuclear engine testing through NRDS operations. (Refer to bibliography.)

Attended meeting with representatives of NVPO, LMSC, SNPO-C, REON and WANL at Huntsville on 15 November 1962, to review the initial RIFT facility concepts, plans and program schedules and to determine availability of the RIFT static test facilities in support of the NERVA engine development program.

\section{Conclusion}

In conclusion, minor effort was required under this subtask during CY 1963 associated with NERVA/RIFT support systems interface; however, it is anticipated that significant effort will be required during CY 1964. 
SUBTASK 3.9 - BIBLIOGRAPHY

RIFT STAGE DEVELOPMENT FACIIITIES

ITEM REFERENCE SUBJECT

ORIGINATOR/ADRESSEE

Itr. 741:M017?

Minutes of Meeting, Lockheed

L.E.White/to Stinnett $11-12-6 ?$

Nuclear Engine Interface Working Group 


\section{S/T 4.I PROGRAM PLANNING \& CONTROL}

ACCOMPLISHMENTS

\begin{tabular}{|c|c|c|c|}
\hline $\begin{array}{l}w / s \\
\text { FERENCE }\end{array}$ & PLANNED & ACTUAL & $\begin{array}{l}\text { EVIDENCE OF } \\
\text { COMPLETION }\end{array}$ \\
\hline \multirow[t]{4}{*}{$2-4.1$} & 1. IMPLEMENT PERT SYSTEM FOR PROGRAM MANAGEMENT & COMPLETED & $\left\{\begin{array}{l}\text { PERT COMPUTER LOG } \\
\text { NETWORK MICROFILM FILE }\end{array}\right.$ \\
\hline & & & $\begin{array}{ll}2322 & \text { LETTERS } \\
2434 & \text { OF } \\
63002 & \text { TRANSMITTAL } \\
63005 & \end{array}$ \\
\hline & 2.SUBMIT BIWEEKLY PERT REPORTS & $\begin{array}{l}\text { COMPLETED } \\
\text { ADDED SCOPE }\end{array}$ & $\begin{array}{l}63005 \\
\text { REPORTS } 63-1 \text { THRU } 63-26\end{array}$ \\
\hline & $\begin{array}{l}\text { THREE MAJOR REPLANNING CYCLES TO SUPPORT } 2322 \text {, } \\
2434,63002,63005 \text { - } \\
\text { MANOR EXPANSION OF PLANNING DETAIL REQUIRED- } \\
\text { FROM } 1500 \text { ACTIVITIES TO } 25,000 \text { ACTIVITIES }\end{array}$ & & $\begin{array}{l}\text { PERT COMPUTER LOG } \\
\text { NETWORK MICROFILM } \\
\text { FILE }\end{array}$ \\
\hline
\end{tabular}


Purpose and Objective

1. Implement a PERT system to provide detailed integrated plans, schedules and corresponding status information as required by program management to monitor, evaluate and control the overall program.

2. Provide biweekly PERT status reports for internal and SNPO-C use.

Accomplishments

Program Planning and Control

REON planning and control operations perform a dual role in the NERVA program. The first of these is the role of a prime contractor with total program or system functions oriented toward major program objectives. The second is the role of a technical participant oriented toward accomplishment of technical objectives at the Azusa, Sacramento, Downey Plants and at NRDS.

The principal functions performed in both areas consisted of the following:

\author{
Planning and Scheduling \\ Monitoring and Evaluating for Management Control \\ Reporting \\ 1. Planning and Scheduling \\ Master program plans and schedules were prepared for the total
} NERVA program. Demand networks were prepared for each program objective or end item to establish explicit programmatic, schedule and interface requirements for all participant plants and subcontractors. The resulting preliminary requirements were reviewed with REON senior task managers for technical compatibility. Revised demand networks and requirements were prepared, approved by REON management, and issued to all participants. Subtask oriented preliminary planning networks were prepared for all plants to support the requirements and objectives defined by the demand networks. Typically, the preliminary networks were prepared under Task 4.1 and reviewed with task managers to verify logic and to obtain time estimates. 
Preliminary planning networks from all participants including subcontractors supporting the demand networks were reviewed by the REON planning group and REON task engineers.

The plans were interfaced, schedule conflicts resolved with the affected participants and program or end item networks were prepared for major program objectives.

This programming cycle was repeated for each major program change or redirection.

Program plans were defined at the start of the contract year by 15 networks consisting of 1500 activities increasing to 115 networks and approximately 25,000 activities by the end of the contract year. A tabulation of all these networks will be found in the handout which I will give you.

2. Monitoring and Evaluating for Management Control

Task oriented networks were processed through the PERT computer program by LRP and REON for their cognizant in-house subtasks.

The biweekly reports from all participants together with the REON subtask reports were reviewed and verified by the planning group, and processed as an integrated NERVA PERT computer program. Biweekly meetings were held between the planning group and REON management to review total program status and define problem areas and corrective action. In addition, weekly management reviews are made of pacing items on critical paths.

\section{Reporting}

Twenty-six biweekly PERT reports were submitted to SNPO-C in accordance with the NASA PERT handbook, dated 30 October 1962 . The reports included activity completions, activity time changes during the latter portion of CY 1963 and logic changes. The report was expanded to include a narrative report summarizing program status, identification of problem areas and indicated corrective action.

Monthly milestone status reports were prepared for inclusion in the monthly technical progress reports. 


\section{Supplemental status information was submitted to SNPO-C as}

requested.

Two-hundred-thirty-five planning networks were submitted to SNPO-C during the course of the contract year.

Added Scope

Program changes have required three more major replanning cycles than were originally contemplated. In addition, it became obvious during the year that more detailed planning networks were required to adequately define these program changes than anticipated. As a result, whereas we started the year with 15 networks and approximately 1500 activities, we finished with 115 networks and approximately 25,000 activities to describe the program recommended in Report RIV-63005. 


\begin{tabular}{|c|c|c|}
\hline QABS & X0. $\mathbf{R}$ & DESCRIPIIOK \\
\hline $\mathbf{D}$ & 004001 & $25 x-A 1,2, \& 3$ \\
\hline $\mathbf{D}$ & 004902 & $H \pi x^{\prime}=4,45,5,86$ \\
\hline $\mathbf{D}$ & 0049003 & Eसx- $7,8,9, \approx 10$ \\
\hline D & 004911 & E-Eugine 1 \& 2 \\
\hline $\mathbf{D}$ & 004912 & EnErgine 3, 4, \& 5 \\
\hline$\infty$ & $\infty, 000$ & 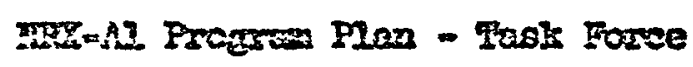 \\
\hline$n$ & opitgen & 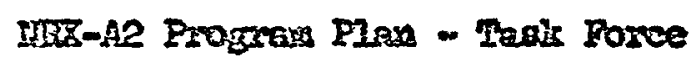 \\
\hline$\infty$ & 0.04932 & IRT-AI HAHL Intexface \\
\hline$\infty$ & ookges & 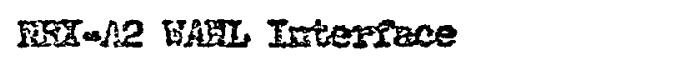 \\
\hline$\infty$ & 004,026 & EST-43 FingL Intexface \\
\hline$\infty$ & colsen & HOL-A4 KKAVL Interiaco \\
\hline$\infty$ & 004983 & DSE-AS WALT Intenpace \\
\hline$\infty$ & 004931 & IXIX-AI IEP Interface \\
\hline$\infty$ & 004935 & IJRE-A2 IRR Inteatace \\
\hline$\infty$ & 0014936 & IHES-A3 IFP Intesfece \\
\hline$\infty$ & 004937 & 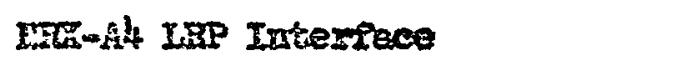 \\
\hline$\infty$ & 004938 & REX-A4 LER Interface \\
\hline
\end{tabular}

\begin{tabular}{|c|c|c|}
\hline Spens & BEV & DAYTE \\
\hline \multirow{17}{*}{2} & $H / c$ & $8-10-63$ \\
\hline & B/C & $8-10-63$ \\
\hline & $n / C$ & $8-10-63$ \\
\hline & $\mathrm{II} / \mathrm{C}$ & $8-10-63$ \\
\hline & $\pi / C$ & $8-10-33$ \\
\hline & $\mathbf{E}$ & $10-8-63$ \\
\hline & $B i v$ & $10-21-63$ \\
\hline & B & $10-18-63$ \\
\hline & A & $10-21-63$ \\
\hline & $3 / C$ & $10-1-63$ \\
\hline & $B / C$ & $10-1-63$ \\
\hline & $\pi / C$ & $10-1-63$ \\
\hline & c & $10-9-63$ \\
\hline & A & $10-1-63$ \\
\hline & $\mathbb{Z} / \mathrm{C}$ & $10-10-63$ \\
\hline & I/C & $10-10-63$ \\
\hline & $n / C$ & $10-10-63$ \\
\hline
\end{tabular}


CY 64 Program Plonning Hetworks

\begin{tabular}{|c|c|c|c|c|c|c|c|}
\hline $\begin{array}{l}\text { SUB- } \\
\text { RASK } \\
\text { PAS }\end{array}$ & $\begin{array}{l}\text { DRAHIDG } \\
\text { FO. } P\end{array}$ & & LESSCRIPITOST & & SHEIS & BEV & DATE \\
\hline 2.1 & 214001 & & Ingine Syster and sockup & & & B & $8-23-63$ \\
\hline 1.1 & 214200 & & Fngine and Cages & & 2 & $A \& B$ & $8-23-63$ \\
\hline 1.1 & 224201 & 2.1 .2 & IIIJUS & & & B & $8-21-63$ \\
\hline 1.1 & 124102 & 1.1 .8 & HBI-A Engare & ' & 3 & $\mathbf{A}$ & $8-13-63$ \\
\hline 1.2 & 124301 & 1.2 .2 & Velves & & 2 & $\mathbf{A}$ & $8-32-63$ \\
\hline 1.2 & 124102 & 1.2 .3 & TPA & & & $\mathbf{A}$ & $8-22-63$ \\
\hline 1.2 & 124203 & 2.2 .4 & $\mathrm{TPA}$ & & & A & $8-12-63$ \\
\hline 2.4 & 244001 & & Ding Irozzle Propallant Feed \& Applied & Regeareh & & $\mathrm{n} / \mathrm{C}$ & $8-23-63$ \\
\hline 1.4 & 144101 & 1.4 .2 & $\mathrm{~T} / \mathrm{s} \&$ Ginbar & & & A & $8-12-63$ \\
\hline 1.4 & 244102 & 1.4 .3 & FV. Agestivis & & & $\mathbf{A}$ & $8-13-63$ \\
\hline 2.4 & 244203 & 1.4 .1 & Iozzile \& Bxt. Developremt & & 2 & $\mathbf{A}$ & $8-13-63$ \\
\hline $2.4^{\circ}$ & 144104 & 2.4 .6 & 1964 Auplled Fezeaxah Progrem & - & & $\mathbf{A}$ & $8-10-63$ \\
\hline 1.4 & 144105 & 1.4 .5 & Dactor Iozzle & & & A & $8-12-63$ \\
\hline 2.5 & 154001 & & Cosatrol Systan & & & A & $8-23-63$ \\
\hline 1.5 & $15 \ln 20 \%$ & & Engline Controls & & & $A$ & $8-11-63$ \\
\hline 1.6 & 164001 & & Counter systen & & & A & $8-13-63$ \\
\hline 1.7 & 274201 & & Pneusetic Power Suppiy & & 2 & $w / C$ & $8-2-63$ \\
\hline 2.8 & 284002 & & System Analysis & & & & $8-27-63$ \\
\hline 2.9 & igl:002 & & IRP Irradiation Refecto Program & & 14 & $\mathrm{H} / \mathrm{C}$ & $8-6-63$ \\
\hline 2.9 & 194003 & & Azurea Irreallation friects Progrea & & 13 & $\mathbf{I} / \mathbf{C}$ & $9-6-63$ \\
\hline
\end{tabular}




\begin{tabular}{|c|c|c|c|c|c|c|c|}
\hline $\begin{array}{l}\text { SURE } \\
\text { TASSE }\end{array}$ & $\begin{array}{l}\text { DRAWIIIG } \\
\text { DOP. } P\end{array}$ & & IESCETHETCA & & signs & HEW & DATE \\
\hline 2.1 & 214001 & & Alt. Pate Haraling GSE & & 2 & $\mathrm{r} / \mathrm{C}$ & $8-13-63$ \\
\hline 2.1 & 214002 & & 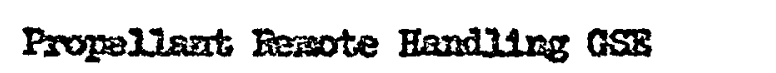 & & 2 & $\pi / c$ & $8-13-63$ \\
\hline 2.1 & 221401 & & 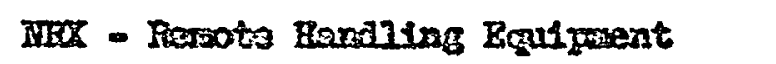 & & & A & $9-3-63$ \\
\hline 2.2 & 224301 & & c/O \& Test Equilpzemt & , & & $A$ & 903.63 \\
\hline 2.3 & 234201 & & 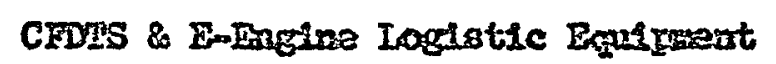 & & & B & $9-3-63$ \\
\hline 2.4 & 244001 & & Instirizentestion systera & & 4 & $\mathbb{\$} / \mathbf{c}$ & $8-13-63$ \\
\hline 2.4 & 244002 & & MRX-A Irastarksentatica & & 10 & & \\
\hline 2.4 & $24 k 0 \times 3$ & & Flont. Irradtation Saries 500 & & 4 & & \\
\hline 2.4 & 244004 & & Yeeh. Irradiatios Series 900 & & 9 & & \\
\hline 2.7 & 274001 & & Prelizicary Flight Safety System & & & $\mathbf{z} / \mathbf{C}$ & $8-13-63$ \\
\hline 3.1 & 314001 & 3.1 .4 & Duet Systom-1 & & & $\pi / c$ & $8-23-63$ \\
\hline 3.1 & 314003 & & HES Dazet Systera gRS-2 & & & $\mathbb{B} / \mathrm{c}$ & $8-23-63$ \\
\hline 3.3 & 324004 & 3.1 .5 & Ens - I Sives Genorator & & & $\mathbb{w / c}$ & $8-23-63$ \\
\hline 3.2 & 324001 & & EIS- 1 Cosp. andivities & & & A & $9=4-63$ \\
\hline 3.3 & 334001 & & xrs- IRe Syrsea & & 2 & $\pi / C$ & $8-13-63$ \\
\hline 5.1 & $51400 x$ & & Sise- Test Zone C & & & $B / c$ & $8-15-63$ \\
\hline 5.2 & 524001 & & Cryogrmie Inboratory Ieat zare A & & & $\mathrm{II} / \mathrm{C}$ & $8-16-63$ \\
\hline$\Xi \Xi$ & 534001 & & FrE-Test Zone H & & 2 & $\pi / c$ & $8-16-63$ \\
\hline 5.8 & 584003 & & STEG-AGC TESp. Iaboretrory & & & $\mathrm{H} / \mathrm{C}$ & $8-16-63$ \\
\hline 5.9 & 594002 & & SIE-Laboratory Facilithy - Sacto & & & $\pi / c$ & $8-16-63$ \\
\hline
\end{tabular}




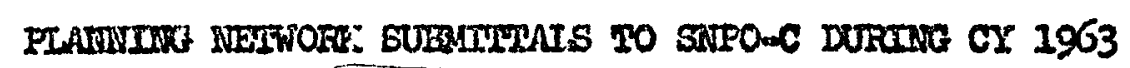

\begin{tabular}{|c|c|c|}
\hline \multirow[t]{5}{*}{$10-26-62$} & 3.1 & 2.1 \\
\hline & 1.2 & 2.2 \\
\hline & $2.4-1$ & $2 \cdot 3$ \\
\hline & $2.4-2$ & 2.4 \\
\hline & 1.7 & \\
\hline $12-7-62$ & 3.66 & \\
\hline $11-30-62$ & 0.0 & $2.3 R$ \\
\hline & $1.1 R$ & $2.2 R$ \\
\hline . & $2.2 R$ & $2.3 R$ \\
\hline & $1.4-117$ & 2.48 \\
\hline & $2.4 m 2 R$ & \\
\hline & 1.5 & \\
\hline & $2.6 n$ & \\
\hline & 2.TR & \\
\hline
\end{tabular}

12-7-62 Progrean Burrisary

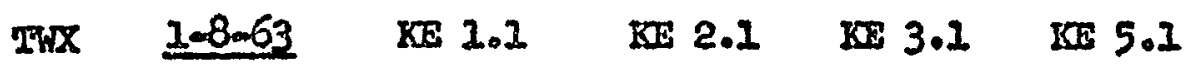

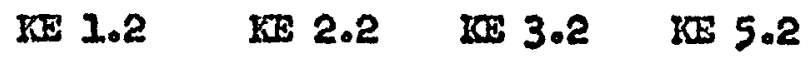

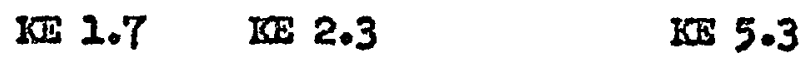

LD 1.92 .4 . 5.9

KE 6.2

TWX N:T:396 1-9063 KC 1.4

IIS 2.5

KE 1.6

ItT $751: 309 \quad 1-25-63 \quad 2.3 \mathrm{kR}$

$\begin{array}{lllllll}\text { Ittx 751:412 } 309-63 & 000 & 1101 & 15 & 211 & 315\end{array}$

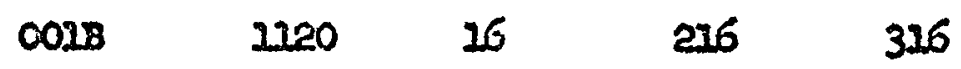

$\begin{array}{llll}1401 & 19 & 32\end{array}$

$1302-1$

$1301-2$

1301-3

- $4.1-4 a$


Plaming lietwork supmitrals s outum During CY 1963

\begin{tabular}{|c|c|c|c|c|c|c|}
\hline \multirow{13}{*}{$\begin{array}{l}45574 \\
45575\end{array}$} & \multirow[t]{13}{*}{$3=22-63$} & P01012 & $P 00001$ & PO2001 & PO3001 & $024683-1$ \\
\hline & & POICla & 1000002 & P0e002 & P03002 & $014683-2$ \\
\hline & & Pogions & P00004 & $\mathrm{PO} 0003$ & F03003 & $014683-3$ \\
\hline & & P01021 & P00005 & $\mathrm{POCO}_{2}$ & $\mathrm{PO} 00004$ & $2301-1$ \\
\hline & & P01022 & 1000006 & PCre005 & Fo3005 & $1301-2$ \\
\hline & & $P 01023$ & P00007 & F02005 & 503006 & $2301-3$ \\
\hline & & 901024 & 200008 & PO2007 & P03501 & 2401 \\
\hline & & & & F02008 & P03502 & 228 VIB \\
\hline & & & & P02009 & E03503 & 27 \\
\hline & & & & $P 02010$ & PO3504 & \\
\hline & & & & F02501 & F03505 & \\
\hline & & & & P02502 & $P 03506$ & \\
\hline & & & & & P03507 & \\
\hline
\end{tabular}

Itr 751:343 . 4-18-63 P0300T

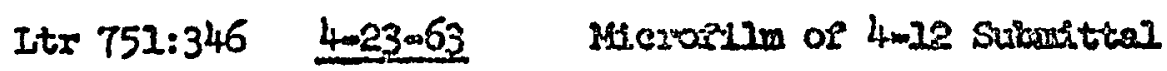

Ltx 751:349 4-202063 502012

P000201

P00027\%

Itr 751:371 6-5063 $\quad$ P03012

P03012

F03013

203014

\$03015

803016

Lit 751:393 I-5-63 $\quad 5000020$

502016

Hand-Carried $7-8.63 \quad$ ro2014

F02018

702019

Itr 751:395 7-12.61] P00032

Litr 751:396 7-26-63 2000032

Itr 751:404 7-19053 P02019 
Itr 751:613 8-30-63

004902

004902

004903

004910

colt972

004931

colyg32

214001" $B "$

214100 "B"Sht I

1714100" $\mathrm{A}^{\text {"sht }} 2$

274201" 1

$174102^{\prime \prime} \mathrm{A}^{\text {"but }} 3$

124101"A"Sht 2

$204302^{\prime \prime} A^{\prime \prime}$

124103"A"

233202

133203

133204

133205

233205

244001

144.201"A"

$144202^{\prime \prime} A^{n}$

144303"A"5ht 2

$141204^{\prime \prime} "$

$144105 " \mathrm{~A} "$

154001"A"Slat 2

$254104^{\prime \prime} A^{\prime \prime}$

164001"A"

164002

174101 ant 2

184001

19400252014
Demand 214001 sat $\#, 2.1$

Demand 214002 Sht $2 \quad 2.1$

Denand 244001 sht $31 \quad 2.4$

Demand $274001 \quad 2.7$

Dermana $314001 \quad 3.1 .4$

Coup. $314003 \quad 3.1$

cong. 314004 3.1.5

$1.1324001 \quad 3.2$

$1.1 .0 \quad 334001$ sat $2 \quad 3.3$

$1.1 .0 \quad 514001 \quad 5.1$

$1.2 .2524001 \quad 5.2$

$1.1 .8 \quad 534001$ sht $2 \quad 5.3$

$1.2 .2584001 \quad 5.8$

$2.2 .3594001 \quad 5.9$

1.2 .4

1.3

1.3

1.3

1.3

1.3

1.4

1.4 .2

1.4 .3

1.4 .1

2.4 .6

1.4 .5

1.5

3.5

2.6

1.6

2.7

1.8

1.9 
$\because .:$

Planning Netirork subutitals to soro-c

During of 1963.

$+\ldots$

Ittr T51:518 $\because$

$2=12-63.194003 \cdots 514$

$224200 \mathrm{~A}$

: 224101A

2341018

$324001 \mathrm{~A}$ क्ष 


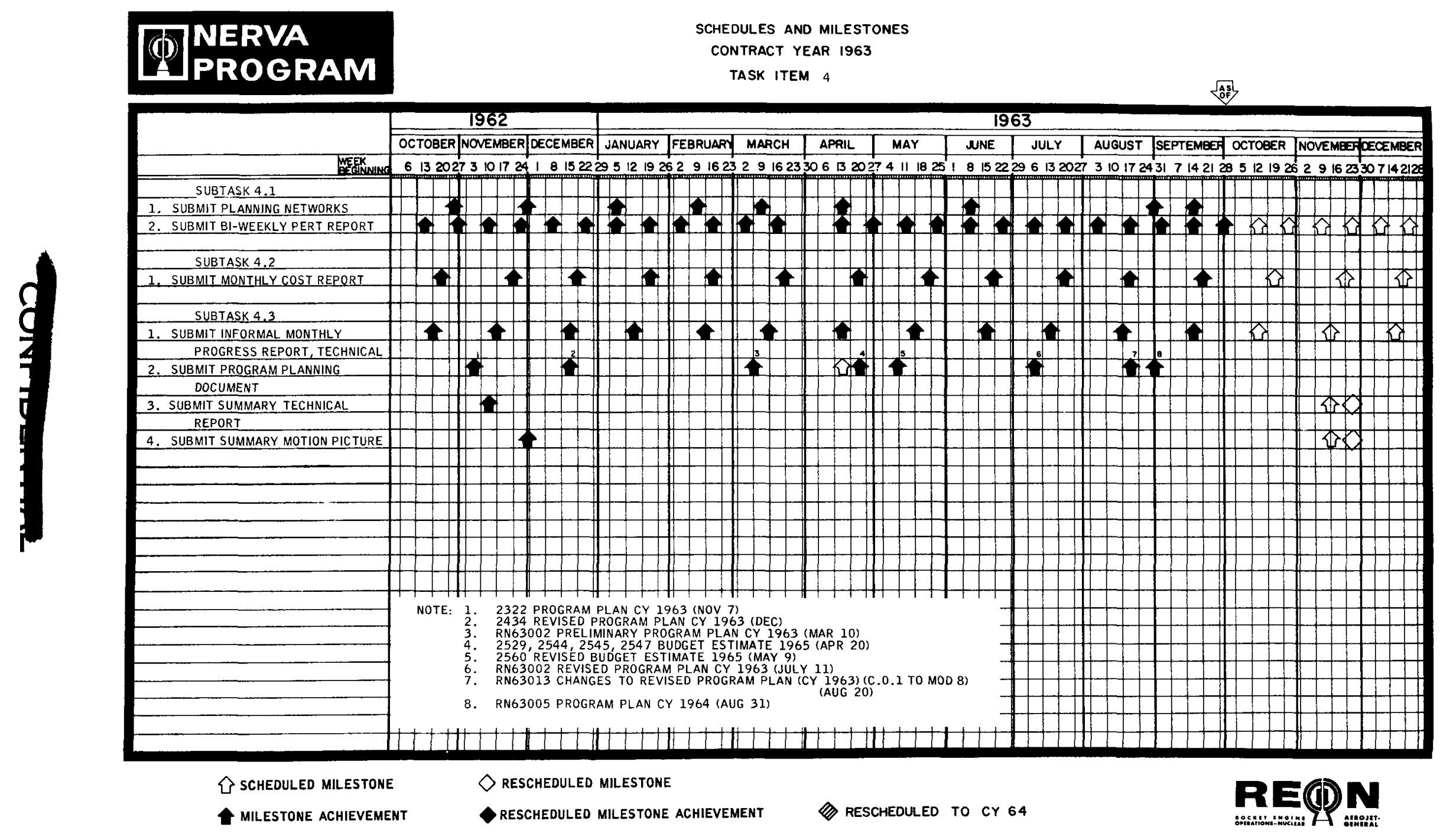




\section{S/T 4.2 FISCAL CONTROL ACCOMPLISHMENTS}

$W / S$

REFERENCE

$2-4.2$
PLANNED

I. DEVELOP DETAILED PROGRAM BUDGETS

2. PROVIDE COMPREHENSIVE COST STATUS REPORTS

3. MONITOR \& CONTROL COSTS \& BUDGETS

\begin{tabular}{|c|c|}
\hline ACTUAL & $\begin{array}{l}\text { EVIDENCE OF } \\
\text { COMPLETION }\end{array}$ \\
\hline COMPLETED & $\begin{array}{l}\text { RU-2-2322, MOD II, CY } \\
\text { 1963 PROGRAM } \\
\text { RN-2434, CY } 1963 \\
\text { PROGRAM } \\
\text { RN-63002, REV, MOD } 8 \\
\text { RN-63013, C/O\#I } \\
\text { RN-63005 INITIAL } \\
\text { CY 1964 PROGRAM } \\
\text { RN-2529, CY } 1965 \\
\text { BUDGET }\end{array}$ \\
\hline COMPLETED & $\begin{array}{l}\text { REPORTS: LO56O- } \\
\text { 10-15 THROUGH }-27\end{array}$ \\
\hline ERFORMEI & $\begin{array}{l}\text { PROGRAM COST ARE } \\
\text { WITHIN LIMITATIONS } \\
\text { REPORTS: LO560-10-15 } \\
\text { THROUGH- } 27\end{array}$ \\
\hline
\end{tabular}

EVIDENCE OF

-2-2322,MOD $\mathbf{Z 1 , C Y}$

$R N-2434, C Y 1963$

PROGRAM

$R N-63013, C / O \# 1$

RN-63005 INITIAL

CY 1964 PROGRAM

RN-2529, CY 1965

BUDGET

THROUGH-27 


\section{S/T 4.2 FISCAL CONTROL ACCOMPLISHMENTS}

$W / S$

REFERENCE

\section{UNPLANNED ACTIVITIES}

ADDED SCOPE

FORMAT CHANGES - CY 1965 BUDGET

EXTENSIVE SEPARATION AEC-NASA COSTS

REVISED REPORTING FORMAT WITH BUDGET CATEGORIES

SIGNIFICANT INCREASE IN MISC ADMIN

TYPE INFORMATION REQUESTS
EVIDENCE OF

COMPLETION

RN-2560 REV. BUDGET ESTIMATE CY 65 RN-63002 ‡ SUBSEQUENT REPORTS DEVELOPMENT FOR CV 1964 COST AREAS - MANPOWER SUMMARIESCHANGED OVERHEAD RATES - REVAMPED COMPUTER PROGRAMS 
SUBTASK 4.2 - ACCOMPLISHMENTS FOR CY 1963

Purpose and Objective

1. Develop detailed program budgets.

2. Provide comprehensive cost status reports.

3. Monitor and control costs and budgets compatible with program objectives and contract limitations.

Accomplishments

1. Budgets have been developed for each redefined program. As you can see from the chart there have been seven basic budgets prepared including those for CY 1964 and CY 1965.

2. Budgets have been adjusted as the program changed or as technical difficulties were encountered.

3. Monthly cost reports L0560-10-15 through -27 were provided.

4. Program costs are within contract year limitations as evidenced by Report L0560-10-27.

5. In consideration of the fiscal year end problems associated with AEC funding, special administrative attention was given this problem in June. Consequently, the expenditures incurred for the AEC funded effort from 1 October 1962 through $30 \mathrm{June} 1963$ were within 1.3\% of the AEC financial plan. Added Scope

As in Subtask 4.1, three more major program cost estimates have been required than anticipated. Also, format changes for the April budget submission and for the CY 1964 definitive cost budgets, has necessitated additional effort. Extensive separation of AEC-NASA costs, revised reporting format and a large increase in miscellaneous administrative type informational requests involving specific cost areas, manpower summaries and changes in overhead rates has resulted in a heavier work load than planned. 


\section{SUBTASK 4.2 - BIBLIOGRAPHY}

Documente to Hhloh subtask 4.2 Nede Irput:

FEFORI/IESTIEAR

Titie

Date

2300

Program Plan

Asegust 1962

2322

Program Plan

Hoveruber 1962

2434

Revlsed IHENA Program PLan

63002

Prellminary Program Plan - CI 1963

Decentar 1962

2529

CI 1965 Budget Estimate

Uaran 1963

2544

CY 1965 Badget Bstimato

Nay 1963

2545

CI 1965 Eudget Estimate

1963

2547

CI 1965 Budget Batimate

us 1963

2560

Berloed CY 1965 Budgot Brtimato

63002

Rerised Program PLan - CI I\$63

Hov 1963

63013

c/O $\$ 1$ Program Plan CX 1963

63005

CI 1954 Progaran FLan

uav 1963

June 1963

August 1963

Eepteniber $1 \% 53$

10560-10-

Tอะue $16-27$

Plocel Gupplanest to Konthly Pragress Ropt.

xonthly (2end

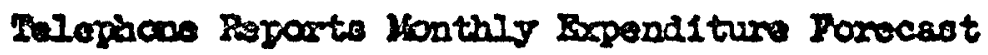

ronthy (Sth)

Iotter Noport Nonthiy Report af Contrector Buloymat

roatily (25th)

Letter Repart Nonthly Repart of Contrector Overtive

Nonthis (25th)

H1scellaneous Ono-IIm Letter and Fhono Roparto

Arerse 1/the

$2-4$ Kooding Eefort 


\section{S/T 4.3 DOCUMENTATION}

ACCOMPLISHMENTS

$W / S$

REFERENCE

2-43A MONTHLY REPORTS

B SPECIAL TECHNICAL REPORTS

C SUMMARY TECHNICAL REPORTS

D PERFORMANCE EVALUATIONS

E SUBCONTRACTOR REPORTS

F SUMMARY MOTION PICTURE

$G$ PROGRAM PLANS

SPECIFICATIONS AND CRITERIA

PROPELLANT FORECAST

MONTHLY LISTING REPORTS

WEEKLY HIGHLIGHTS REPORTS

ADDED SCOPE

WEEKLY SIGNIFICANT EVENTS REPORTS
ACTUAL

COMPLETE

COMPLETE

COMPLETE

COMPLETE

COMPLETE

COMPLETE

COMPLETE

COMPLETE

COMPLETE

COMPLETE

COMPLETE

COMPLETE
EVIDENCE OF COMPLETION

REPORT "LO560-10-16 THROUGHT 27

93 REPORTS REPORT \#2323, 3 VOL. REON LTR NOS. 756: $355,760: 3385 \$ 765: 575$ REPORT "LO560-10 SUPP. TIME'S ETC. PROD NO. M-382- 379 8 ISSUED IN 30 BOOKS 82 ISSUED

12 ISSUED

7 ISSUED

50 ISSUED

26 ISSUED 
SUBTASK 4.3 - ACCOMPLISHMENTS FOR CY 1963

Purpose and Objective

1. Provide the following:

A. Monthly progress reports

B. Special technical reports

C. Summary technical report

D. Performance evaluation report

E. Subcontractor report

F. Summary motion picture

G. Program planning reports

H. Specifications and criteria

I. Propellant forecasts

J. Monthly listing reports

K. Weekly highlights TWX

I. Weekly significant events reports

Accomplishments

All planned accomplishments were completed.

1. Informal Monthly Progress Report, Technical

Twelve reports (Letter Report No.s L0560-10-16 through L0560-10-27)

were submitted in compliance with this requirement. The pages in this report increased from 144 in Report L0560-10-16 to 261 pages in Report 10560-10-27, representing an $80 \%$ increase in content between the first and last reports.

Supplements to this report were:

Fiscal supplement - 12 reports issued

Reliability and quality assurance supplement - 6 reports issued.

$4 \cdot 3-1$ 


\section{Special Technical Reports}

Eighty-eight reports were produced. The number of reports increased from about 5 per month at the beginning of the contract year to about 10 per month at the end of the year. The size of the reports increased as the year progressed. Some reports, such as the data books, consisted of several volumes and thousands of pages. It is estimated that 16,275 pages were published.

3. Summaxy Technical Report.

Summary report for contract year 1962 in 3 volumes, Report No. 2323 dated November 1962, was submitted 15 November 1962. Preparatory work for the submission of summary report for contract year 1963, to be submitted 15 November 1963, was carried on during the year.

4. Performance Evaluation Reports

Three evaluations of subcontractor performance were submitted: Letters 765:355, 760:3385, and 765:575, dated 15 January 1963, 30 April 1963, and 10 August 1963, respectively.

\section{Subcontractor Reports}

Subcontractor reports were submitted as requested. REON Report No. L0560-10- supplement is submitted monthly, consolidating reliability and quality assurance reports of REON, IRP, Westinghouse Electric Corporation, the Bendix Corporation, and American Machine and Foundry Corporation. The weekly significant events and reactor component test program progress report is submitted weekly. Westinghouse Electric Corporation TMEs are submitted directly。

\section{Summary Motion Picture}

A summary motion picture for contract year 1962 was submitted on 30 November 1962. This delay from November 15 to 30 was concurred in by SNPO-C to get additional hot bleed information in the movie. Film strips have been taken' throughout contract year 1963 preparatory to production of the summary motion picture for contract year 1963 schedule for submission on 25 November 1963.

\section{Program Planning Documents}

Eight program plans ere published during the year, consisting of 30 volumes. 
8. Work Accomplished but not Specifically Called Out in Work Statement

Twenty specifications and 62 design criteria were published. The most significant of these was the NERVA engine model specification no. AGC 10095C, dated I November 1962 and revised 12 July 1963.

Other periodic publications were:

Monthly listing report - 7 issued

Weekly highlights report (TWX) - 50 issued

Weekly significant events report - 26 issued

Propellant forecasts - 12 issued

Added Scope

1. A requirement for the weekly significant events report did not exist until after RN-63002 was prepared.

2. When the budget estimates were made for RN-63002 - preliminary draft, program plan for CY 1963, the "Special Technical Reports" requirements were averaging about 5 per month based on the months of December, January, and February. At that time the estimate allowed for some increase in report requirements but not nearly twice the effort. The average output per month from April through September was 10 reports with 14 being published in September. In addition, the size of the "Special Technical Reports" increased, e.g., the instrumentation data book report no. 2320 grew from 2 volumes and about 600 pages in April to 5 volumes and 1300 pages in September.

3. The budget estimates for $\mathrm{RN}-63002$ were based on producing a program for CY 1964-1965 of about 800 pages covering approximately 47 subtasks. Actually four additional program plans were made for a total page count of 3464 pages - an increase over that estimated of about $350 \%$. The last of these plans increased the number of tasks reported to 140 subtasks and sub-subtasks. In addition some of these plans were produced on very tight schedules requiring considerable overtime in the reproduction departments. Additional effort was expended in producing the budget estimates for 1965 because of a completely new format and method of presentation requiring fiscal year budgets and contract year budgets were developed. 


\section{SUBTASK 4.3 - BIBLIOGRAPHY}

(This worix includes edfing, typing, printing, binding, and coordination of report production.)

\section{A. Program Planaing Documents}

Report IHO. Wol.

파닐

Date

2322

I Program Plan, Cy 1963

November 1962

II

do.

2434

Revised NERTA Engine Program and Associeted Tasks

RII 63002 I Preliminary Drait, Progrem PIan, CI 1963

November 1962

December 1962

March 1963

RIII 63002

II

do.

March 1963

I Revised Prograrn Plan, CY 1963

June 1963

III

do.

June 1963

III

do.

June 1963

2529

I AEC Budget Estimate, FF 1965, Schedules 20 and 216 through 91

Niey 1963

II AEC Pudget Estimate, II 1965, Schedule 2la Nay 1963

III AEC Budget Istimate, FII 1565, Schedules 189

Nay 1963

2544 NASA Eudget Estimate, C.I 1965, Schedules 189

$2545 \quad$ Addendrm Budget Istimate - 1965\% GNE, Propellants, and SNPO-II Supporac

May 1963

2ury 2963

2547 Addendum II = Budget Isitmate - 1955

Miny 1963

2560

I Revised Eudget Estimate, FI 1965, AIC Schedules 20 and 276 through il

May 1963

II Revised Eudget Estimaie, FI 1965, AIC Schedule 210

May 1963

III AEC schedules 189, FF 1965

May 1963

IV ITASA Schedules 289, CI 2965

May 1963

V Addendum I - GFE, Propellants, a:II SiPPO-II Support

VI Addendum II - Altemate Plan, Reduced FII 1964 Eudget

May 1963

May 1963 
A. Pragram Planning Documents - costd

Report No. Vol. Thtle Date

IDI 63005 I Program Plan, CI 1964 - August 1963

Summaries and Work Statements

II Program Plan, CI 1964 - Augret 1963

TNIADs for Tasks 1 through it

III Program Plan, CI 1964- August 1963

NTADs for Tasks 5 through 9

IV Progrim Plan, CI 1964 - Ausust 1963

Composite Cost Study

V Program Plan, CI 1964- Auguat 1963

WAYIL Cost Estimates

VI Progrem Plen, CX 1964 - Support Augrst 1963

Equipment Provistoning I1sts

VII Frogrom Plan, CI 1964. August 1963

Addenda 1 through 6

VIII Program Plan, CI 1964. - August 1963

Addenda 7 through 18

FN 63005W WANL Portion of Frogram Plan for CI 1964

September 1963

RN 63013 C Changes to Revisel Prograin Plan, cr 1963 (C.0. 1 to Mod. 8)

August 1953

B. Monthly Reports

Informal Monthly Progress Leticers (Report 1Nos. I0560-10-16, October 1962, through I0560-10-27, September 2963)

Fiscel supplement to Informal Monthiy Progress Latters (Hos. L0560-10-16 through (0560-10-27)

Rellability and Guality Assurance Supplement to Irformal Monthly Progress Letters (HOB. I0560-10-22, April 1963, through I0560-10-27, September 1963)

Nonthly Ifsting Reports (Issued for February 1963 through August 1963)

Fropellant Forecasts (12 1ssued)

c. Weekly Reports

Weekly IIghlists TWX Reports (No. 1, atd 10-2b-62, through \#50, atd 10-2-63)

Weekly Significant Events and Reactor Component Test Program Progress

Reports (No. 1 for period April 9 - 15, 1963 through Ho. 26 for period

Septemicer $24-30,1963)$

D. Sunmary Technical Report

Report Ho. 2323, Yolumes I, I, and III, summary Report for CI 1962, was issued in November 1962 . 


\section{E. Subcontractors Reports}

Tucorporated in Fiscal Supplement and Reliability and Quality Asburance Supplement to Informel Mionilily Progress Letter Reports, in the Weekly Significant Ivents and Reactor Component Test Program Progress Reports, etc.

P. Periomance Evaluations

These reports were submitted by Letters $765: 355,760: 3385$, and $765: 575$ dated 15 January 1.963, 30 April 1963, and 10 August 1963, respectively.

a. Summary Motion Picture

Production Iro. M-382-379

H. Special Technical Reporte

Report No.

2275, Rev。

2275, Rer.

2275, Rev。

2276

2277

2278

2305

2316

2320

2320, Rev.

2320, Rev.

2320, Rev。

2321

2402

2403

$2409 \ldots$

Preliminary

Rev. $A_{2} \mathcal{B}_{8} \mathrm{C}$

2410
Thile

Date

Materfals Properties Data Bools

do.

do.

Engino Systems Data Book

IVBRTA Program o Radiation Eriects Duta Book

Interim Report - MERVA Engine Thernodynamic Cycle Solection

Compartson or clinbal and Gas injection Systems for Thinast Vector Concrol of INTEXA Engine

Oparational Sarety Evaluation of Elsol Complex Instrimentation Data Book

$\begin{array}{ll}\text { do. } & \text { (2 Volumes) } \\ \text { do. } & \text { (3 Volumes) } \\ \text { do. } & \text { (4 Volumes }- \text { Vol. IV } \\ & \text { consists of } 2 \text { books) }\end{array}$

Radiation Esrects Facility, Conceptusl Design MEEFIVA TPA/ASIR Faclility (Sacramento)

Support Systerns for a Typleal Development Progrom

Aralyitical and Experimental Evalui : on of Ij]ectors with a $90^{\circ}$ Thurn for Ose in IIS-I

JPDS Nuclear Rociset Ingine Static Test Carplex Operational Requirements

October 1962

$1-30-63$

July 1963

November 1962

$2-15-63$

$10.23-62$

Issued in

Noveraber 1962

October 1952

Jenuary 1963

Apri1 1963

Tuly 1963

October 1963

$10.4-62$

10.19 .62

ITovember 1962

February 1963

PreIiminary Design Paclsage - IIS-I
November 1962 
Fi. Speciel Technical Reports - contd

Report No.

$$
2420
$$

2421

2421, Rev。

2429

2433

2467

2473

Freliminary

2473

2474

2477

2481

2482

2483

2487

2492

2493

2499

2502

Preliminary

2502, Rev。

2502, Rev.

2506

$\%$

2507

2510

2506 Addendum 1
Mitle

Preliminary Survey - Muclear Rocket Prow pulsion Systems for Advanced Applications

RIFT Safety ReviEW Program - NERVA Systems Description, IIERVA Prozram, SINP-1

do.

Standard RERTVA Folne Anajytical Model for Radiation

Prel Iminary, NRDSeNWRYA Nuclear Rocket Ingine Auriliary Static TeBt Facility Study

Progrean Plannlog Details, INERVA Component Radiation Program, CD/WW - Engine Auxiliary Static Tert Facility Study

Data Cotained from Mirst Irradiation Test on Structural llaterials

do。

Prelininary Deslgn Report, MERVA Exhaust Duct, Iarge Radius mlbow ACO-2 Duct

IEEFIPA Support Equipment Provisioning Ifrta and Scheäule

Fressure Vessel - Reacior IntexPace Ioøds Report

Fanno Iine Tables, MIETTA Prograin

Raylefin Iine Tailes, NERPA Program

REOT Rolikbility and Quillty Assurance

Program Plan., MirRli Program, Fieb. 1963

Standard Nutiva Ingine Analytical Model

Por Rediation Anelysi:3

Scalo Hodel EeatmTramsier Tests of NWEVA

WIHFA Jisgine Component Weight and Balance Report

Operation Requirements for Huclear Roclset

Engine Test Stand No. 2 at MRDS

Raslc Criteria for Frgine Test stand No. 2 at NKDS

do.

Mendatory Facility Additions to Activace ITSS-I at IRRS

Prelininary Test Speclifications for Ground Teat Reactor (GIR) Testa of $4-20-63$

Compondium of Radiation Effeats Test Plan, Speciffcations, and Jest Results

Ens-1 Fluia Requirementis Addendum
Date

Published 5-9-63

Novemiber 1962

Auguat 1963

February 1963

$12 \approx 28.62$

Inated in

Desember 1962

$1-25-63$

$4-15-63$

August 1963

Febzuary 1963

Trebruary 1963

$2 \approx 8 \times 63$

$2-8-63$

February 1963

February 1963

April 1963

April 1963

Issued in

Merch 1963

May 1963

JuIy 1963

June 1963

Issued in

Merch 2963

June 1963

$$
4.3-42
$$


io Special Technical Reports - contd

Report No.

2512

2514

2516

2518

2520

2531

2537

2543

2551

2554

2556

2563

2569

2573

2574

2518

2584

2585

2592

Pralinionary

2597

2603

Prelfoinaty

2603 , irins mistre

Incident Roport - Meteriala Tegt Program, 30 March 1963

Tinal Test Specifications for Ground Test Reactor (GIR) Teats of $4-20-63$

HFX Operational support Plon - Preliminary Draft

Dynamic Anelysiss o Kivf BhA Reactor Core Cluster Asscongly

Postwoperative Requirements - BolAAD BIag. , IEIS-I

Security Manvals WuDS

FuOr SIFO Moating Pregentation Charts

Con. IT Fogise Sirariation Repors

Ixparireatal Investigation on Heat Trensfer to Hyaxocra in Tubes

Prelituinsmy Feat Speciflcatsons for ASTR

Reciranical Pallet Test of 6m15m63

Prelinisary Test Plan oold Flow

Davelcarenc Test Byatem

Preliminaty gregc Specivications - Control

Druar Actuatoro Coriposatri

ringl Fest Spees fo: A3TR Nochanical Pallety Tagis oi $6 \mathrm{~m}-15 \mathrm{c} 63$

Erogram Plaming Details Ior CD/IW

Tinal Tost Plan aed Feat Spscirlcation for

Gavae Isanurentit of loaffied ASIR Test

of 60.15063

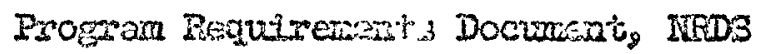

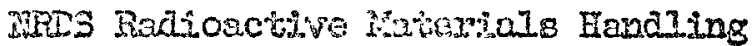

Decontonination and Storage Cormlex

Iroluation ane Conjarnson of Attitude-

Control Sybtom ios spacecrait with IVENTA

Fingrinas

Tasix 3.8 - ITwos Rudionctive Moterials

Bandings, Decontcmination, and storage

Complex Desiten Criteris

Irvalustion of Fostow Operative Destruct

Syrtim Coucopts

Tasy 3.8 - Ergine Transport System

Hointonance WIdg. Desiga Criteria

do.
Date

May 1963

Apre11 1963

March 1963

May 1963

1 Apri1 1963

Apr. 10/11, 1963

30 June 1963

Niay 1963

Issued

$5-2-63$

1 Mey 1963

Hey 1963

Tune 1963

Mry 1963

June 1963

Tune 1953

Irne 1963

Masled

$6 \times 26 \infty 63$

June 1963

$8-9-63$

June 1963

Argast 1963

\section{$4 \cdot 3-5 a$}


IX. Specfal Rechnical Reports - contd

Report No.

2605

2622

2626

2628

2630 ,

Yol. I

2630,

Appendix A

2636

2640

2641

2652

2656

2657

2660

2665

2667

2668

2673

2678

2683

2691

2698

2599

2703
Final Test Specifications for Ground Reactor (CIR) Tests

Tinal Test Spectfications Por Ground Test Reactor (GIR) Tests oi T-2T-63

Preliminary Test Spectifications for cround Ilest Reactor (GLR) Tests of 8-24-63

Huclear Fngine Sizing Analysis (Briefing to NASA sometime in 1963)

Preliminary Design IERYA Rharast System

ETS-1, SST-2 Duct

$$
\text { do. }
$$

SS Materials Control Instruction Manuel for RTERVA Progrom

Preliminery Test Speciplcation for Ground Reactor Tests of 9-7-63

Preliminary Test Reports Por GIR Tests during May 13 - 19, 1963

Aneiysis of the Frat Ifentron and Carma Ray

Envircment - IRP Mechanical Radiation Test 901

Organization of WHRFA Test Operations

NEEFA Test Operations and Support Serices Contractor Responsibilities at MPDS

Final Test Specs Por GIR Tests Nos, 8 and 9 of $9-21-63$

Finel Test Specification for Second Hechanical Pallet Test at ASIR, Tests of 9.3-63

Final Test Specificaflons for Plum Brook Reactor Facilities Tests of August 1963

Structural Integrity Rests - Rectangular Coolant Channels

Final Test Specification for OIR Test No. 10, Tests of 9.21 .63

FIS- 1 Design Criteria

Kiwi-B2A Design Review

Strain-Gage Research and High-Output Transauucer:

INRX-AI Reactor Ranpower Jt1lization, NRDS

IVES Duct (551-2) Conceptual Design

sumary of RCRPA Instrumentation Review at SWPO-C, August $13-15,1963$
Date

June 1963

September 1963

September 1963

July 1963

Majled

$7-18-63$

30 sept. 1963

$8-5-63$

$8-5-63$

August 1963

September 1963

September 1963

10 sept. 1963

September 1963

Issued 9-13-63

September 1963

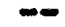

$$
4.3-6 a
$$


9. Sprciel Techo:cel Bgrorta = coirga

Ryport 10

T12

Date

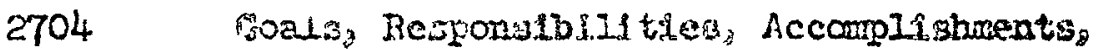
Who integration, Subtak 3.1

2T10 Cold FIow Dovelonnent Jeat Sysiem Plan

Wetifi Program Coramulications Proxadure Nemeal

Septemis or 1963

Septemitser 1963

Issued in

October 1962

1. Specitications and Dezion Criteria

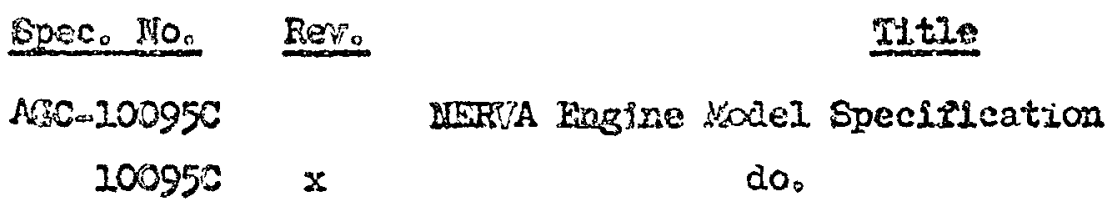

Date

1 Hovemiber 1962

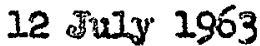

Date Relsased

\begin{tabular}{|c|c|c|c|}
\hline$A . C-10095$ & & $\begin{array}{l}\text { Engine, Rocket, Wuciear, Sufelded, got } \\
\text { Eleed, A330m5 }\end{array}$ & $-\infty$ \\
\hline 10125 & $\mathbf{c}^{\prime}$ & Velicle, Justallation, Engine, Thelnar & $7-17 \cdot 63$ \\
\hline 10126 & A & Loconotive, 80 Fon, iñclear Fivironment & $7-15-63$ \\
\hline $1013^{4}$ & A & Cax, isnued, Costrol, Muclear Enviroment & $10.3 \circ 62$ \\
\hline 10134 & $\mathrm{~B}$ & do. & $7-26 \infty 63$ \\
\hline 20236 & B) & $\begin{array}{l}\text { Positioning sinisystem, Overinesd, for } \\
\text { Renuto operations }\end{array}$ & $7-26-63$ \\
\hline 20237 & $A$ & $\begin{array}{l}\text { Foraling Sularistein, Foor lounted, for } \\
\text { Remote Operations }\end{array}$ & $10-3-62$ \\
\hline 10138 & A & $\begin{array}{l}\text { Teat Systern, Jerelownent, cold Wlow, for } \\
\text { Si30.5 Eagine }\end{array}$ & $12=31-62$ \\
\hline 10238 & 9 & $\mathrm{CO}$ & $5 \infty 16-63$ \\
\hline 10144 & & 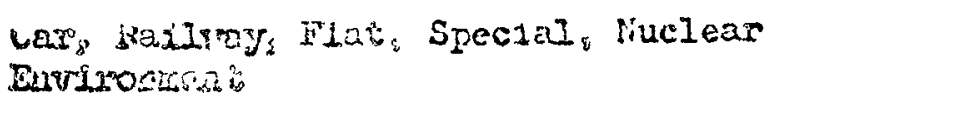 & $-\infty$ \\
\hline 10245 & & 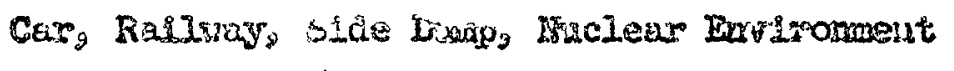 & $\infty$ \\
\hline 10146 & & $\begin{array}{l}\text { Practor Mhonel/felldozer, Rerote Radio } \\
\text { Costisolled }\end{array}$ & 3.02063 \\
\hline 10149 & & Expeno, Erisriec plock 1 , Deaten Spec。 for & 9.15 .63 \\
\hline 10192 & & 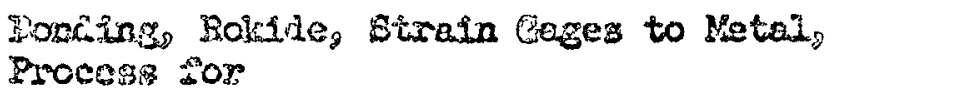 & $7-30.63$ \\
\hline 10193 & & 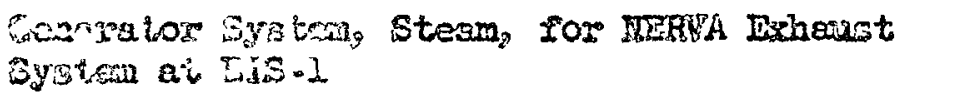 & $5 \times 20.63$ \\
\hline $102 \% 2$ & & 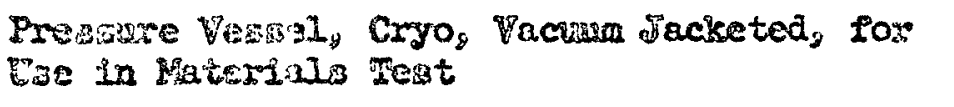 & $8.26 \times 63$ \\
\hline 10273 & & 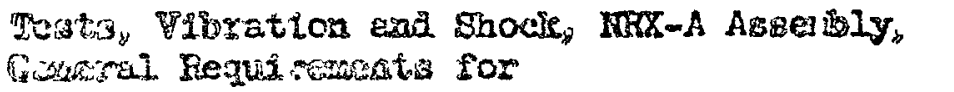 & 9.19 .63 \\
\hline
\end{tabular}


I. Speciflcations and Desizn Criteria * contd

Desion

Criterle Rev.

IDC-02 c VaIre, Slautori, Tarli, (TSOV), for Heated and Bot-Bleed Engines

04 B Valve, wribine Power Control (IPCV) por Fot-pileed Fongive AJ 30.5

06 B Pressure Vessel, Hydrogen, for Hot-Bleed Engine Air30-5

o7 B Iine, Pump Suction, for Bot-Bleed Bngine AT $30-5$

08 I Inne Assembly, Fump Discharge, for Heated and Hot-1leed ingines

14 Thrust Chamber Assenibly

18 C Bimulator, Gen. If, Nuclear Rocket Engine, Eeated Bleed, AI3I-6

19

22

24

26

28

29 -

30

32

36

37

39

40

41

$4.1 / 1$

$41 / 2$

$41 / 3$

$41 / 4$

Iine Assembly, Propeliant, ior the MRX-A Reactor

A Itne Assembly, Tusbine Brhaust, for Hotw Bleed Ingine AJ30-5 Engine AJ30-5

Diaphram, Rurstig $\mathrm{P}$, Por IITRTA Hot-Bleed Engine As 30.5

Corpling Assemizly, Gutar Disconnect, PS, Eot-Bleed Bargine AJ30-5 Bot-Bleed Tugline A $30-5$

Parik, Storase, Pnewarits, for Hot-Bleed

Eagine AJ 30.5

Velve, Rellef, FG, for IIIFIFA Elot-Bleed Engline $1530-5$

Talve, Check, 1/2" The Siza, Fresmatic

System Hot-illeed Ingine AJ30-5

Valve, Check, 1-I/4" Tube Size, Pneumatic System Hot-nIeed ragiane A $30-5$

Line, PFs, Eot-Eileed Fugino

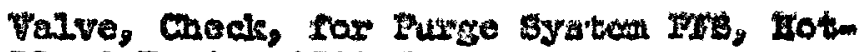

Daie Released

$1-2-63$

$5-3-63$

$4-15-63$

$5-29-63$

$11-27-62$

$7-25-63$

$9-19-63$

$11-1-63$

$4-23-63$

Harness, Electarical, Iot-lileed Engino AS30-5

$10-31-62$

$10-31-62$

Valve, Prescure Reducing, Tank, PS, Hot-Blead

Disconnect Asssmbly, Remote, Prs Lines, for

$3-8-63$

$10-31-62$

$12-3-62$

$3-4-63$

Veive, Stantoxf, PB, Hot-isleed Dogine AT30-5

10-31-62

2-27-63

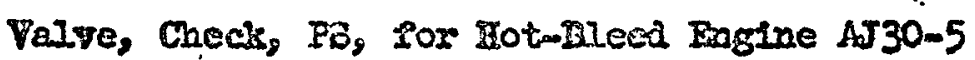

$12-14-62$

$3-6-63$

$3-6-63$

$1-9-63$ Mleed Eagine As30-5 
I. Specifications and Desion Criteria - conta

Design

Criteria

Rev.

Tit.tie

Date Released

NDC- 42

FilterB, PS, Ilot-Bleed Frisine AJ30.5

$10-31-62$

Mransducer, Pres., Poten. Type, for Use on T.C. Itot-alleed Ingine AS30-5

$9-23-63$

44 Tranaducer, Term, Res. Therm., for Use on T.C. Fot-Bieed Ingine A $30-5$

$9-23-63$

50

Ine Assembly Ifiq. Hyd. Propellant, ITS-I

Fun Tank to IFETV Ingine

52

Exhmut Syatem, MERTA, for Jest Stand EIS-1

$10.15-62$

Duct Assemibly, Ixhaust, Supersonic, Large

Radius Elbow, for IVES

54

Generator Syrstem, Cas

2.1 .63

53

Trailer, Installatioa, for Exhoust Desct Assembly

56

Fozzle, Inquid Hydrogen Cooled, for IRRK-A

Reactor Test Aasemilies

57

Hozale Asserioly, Propellant Cooled, for

Hoto Elleed Ingine AaT30-5

58

Tharbogum, Asserably, for Zlot Bleed Engine A.5 30.5

59

Instrimentation, Exhoust Duct Assemoly,

Reguirements for

$2-1-63$

$2-1-63$

2-1-63

$11-14-62$

$6-14-63$

$4023-63$

$2-1-63$

60

Tants Asserbiby Rung Propeliant Feed, Por

Nuclear Rociset fingine Simalator Gen. II Mod.

$12.26-62$

61

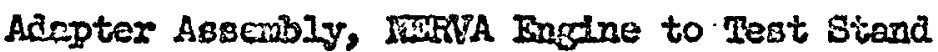
Finrust structare

62

Pressure Vessel, Eydrogen, for IRX-A Reactor Test Ass 2 mithles

65

Penotraticas, Iop Sntald, IFIs-I Ingine

Compartment

66

Irechast Systery, HEFriz, (SST-2), for use at Teat Siand EMs-1

67

Duct Aascmbiy, Firaust (EST-2), for IRHFA

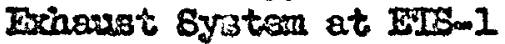

68

Inetrumsatation, Frhoust Duct Assemibly

(SST-2) at ENS-1, Requirmants for

$12.21-62$

$2-25-63$

$6-28.63$

$9-16.63$

$9-16.63$

$9-16-63$

69

Installation ard Rernorel, IFES Exhoust Duct

(SST-2) at EISor1, Process Por

$9-16-63$

To

Trafler Assembly for Mransporthe the IIIS

(SBT-2) Dharst Duct

9.160063

T

Fabrication and. Assenisiy of Wes Echaust Duct

Asvmibiy (SST-2) at FIS6-I, Process for 
I. Specisications and Desisn Criteris - conta

Dosign Criterfa Reto

IDDC -73

74

75

76

T7

18

79

80

81

82

83

84
Thitie

Aftercooling System for IHERTA Ingines

Covers, Dust, for E-Series Engrines

Stand, Eold, Iot-Bagine Remote

Irailer, Checleout, E-Ingine

Contoiners, for Iransport and Storage of Radioactive Materials

Waste Digposal, Radiosctive Hateriels, Equiproent for

Prime Hover, Por Hendling IES Duct Trailer in huclear Invilonmont

Intercell Transfer System, ErIAAD Bldg, MRDS

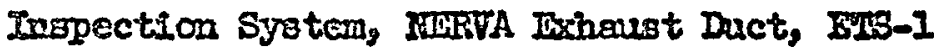

Hot Cell Materifal Transfer Syistern, PostOperative Cells, ENIAD BIdg., IROS

Test Stand Malfumctions and Iquipment

Requirements ot EIS-1

Decontamination System, ivas Duct at Eus-1
Dete Released

$9-30-63$

$9-30.63$

$9-30-63$

$9-30.63$

$9-30-63$

$9-300063$

$9-30-63$

$9-30-63$

$9-30.63$

$9-30-63$

$9030-63$

$9-30-63$ 


\section{S/T 4.4 CEITRAL DATh SYSTEIm}

ACCOMPLISHMENTS

$w / s$

\section{REFERENCE}

PLANNED

ACTUAL

$2-4.4$

ESTABLISH AND MAINTAIN A CENTRAL DATA SYSTEM

COMPLETED

FOR STORAGE AND RETRIEVAL OF SIGNIFICANT

PROGRAM DATA

EVIDENCE OF COMPLETION

REPORT NO $751: 378$

DATED 10 JUNE 1963

MONTHLY ENG.

DWG LISTS

MONTHLY SPEC.

STATUS REPORT

$765 \cdot 5838 / 15 / 63$

$765: 6519 / 27 / 63$

ENGINEERING DATA

FILES (95000 CARDS) 
SUBTASK 4.4 - ACCOMPLISHMEITSS FOR CY 1963

Purpose and Objective

Establish and maintain a central data system for storage and retrieval of significant program data.

Accomplishments

1. Preliminary criteria were established and forwarded to SNPO-C in June.

2. Implementation of a mechanized system scheduled to be accomplished in July was accomplished.

3. Issuance of monthly lists of engineering drawings was initiated in August.

4. Issuance of monthly specification status lists was initiated in August.

5. All available engineering drawings are microfilmed. Approximately 95,000 microfilm cards are already in storage. 


\section{SUBTASK 4.4 - BIBLIOGRAPHY}

Lettex Dated

751:348 10 June 1963

$765: 583 \quad 15$ Avgust 1963

765:651 21 Septeniber 1963

$4.4-1 a$ 


\section{S/T 4.5 SUBCONTRACT ADMINISTRATION}

ACCOMPLISHMENTS

\begin{tabular}{|c|c|c|c|}
\hline $\begin{array}{c}w / s \\
\text { REFERENCE }\end{array}$ & PLANNED & ACTUAL & $\begin{array}{l}\text { EVIDENCE OF } \\
\text { COMPLETION }\end{array}$ \\
\hline $2-4 a$ & ISSUE SUBCONTRACT DOCUMENTS & COMP & $\begin{array}{l}31 \text { CONTRACT } \\
\text { DOCUMENTS }\end{array}$ \\
\hline$b$ & $\begin{array}{l}\text { LIAISON BETWEEN REON MGMT AND } \\
\text { SUBCONTRACTORS }\end{array}$ & COMP & $\begin{array}{l}\text { CONTINUING } \\
\text { EFFORT }\end{array}$ \\
\hline C & $\begin{array}{l}\text { REVIEW SUBCONTRACTOR PROCUREMENT } \\
\text { POLICY \& PROCEDURES }\end{array}$ & COMP & $\begin{array}{l}\text { CONTINUING } \\
\text { EFFORT }\end{array}$ \\
\hline$d$ & $\begin{array}{l}\text { SYSTEM FOR ACCOUNTABILITY OF } \\
\text { GOVT PROPERTY }\end{array}$ & COMP & \\
\hline$e$ & PROCUREMENT APPROVAL REVIEWS & COMP & $\begin{array}{l}414 \text { PACKAGES } \\
\text { PROCESSED }\end{array}$ \\
\hline $\mathbf{F}$ & COST AND PRICE ANALYSIS & COMP & $\begin{array}{l}\text { CONTINUING } \\
\text { EFFORT }\end{array}$ \\
\hline
\end{tabular}


SUBTASK 4.5 - ACCOMPLISHMENTS FOR CY 1963

\section{Purpose and Objective}

1. Issue subcontract documents.

2. Provide liaison with subcontractors.

3. Review subcontractor's policy and procedures.

4. Provide a system for accountability of government property.

5. Review subcontractor's procurement activities.

6. Conduct cost and price analysis.

Accomplishments

All efforts required under this subtask has been accomplished, the major areas are:

1. Fifteen major contract documents, covering $\$ 37,720,617$ in work were negotiated, issued, and approved. Eight smaller subcontracts, covering $\$ 101,611$ in work, were also issued.

2. Four hundred and fourteen procurement approval packages were processed, representing a total of $\$ 8,739,186$ in place of procurements requiring consent action.

3. Subcontractor procurement policies and procedures were reviewed on a continuing basis in conjunction with the procurement approval reviews.

4. The government property accountability system is in operation and has recorded acquisition of property valued at $\$ 2,394,588$ for the contract year.

5. Cost and price analysis functions have been performed on a continuing basis, both on major subcontracts and on procurement approval requests. 6. Subcontractor costs have been controlled essentially on ur below planned budgets. 
Added Scope

Repeated programming has increased significantly the planned workload. Capital equipment accountability requirements associated with AEC accounting practices have proven more comprehensive than estimated. 


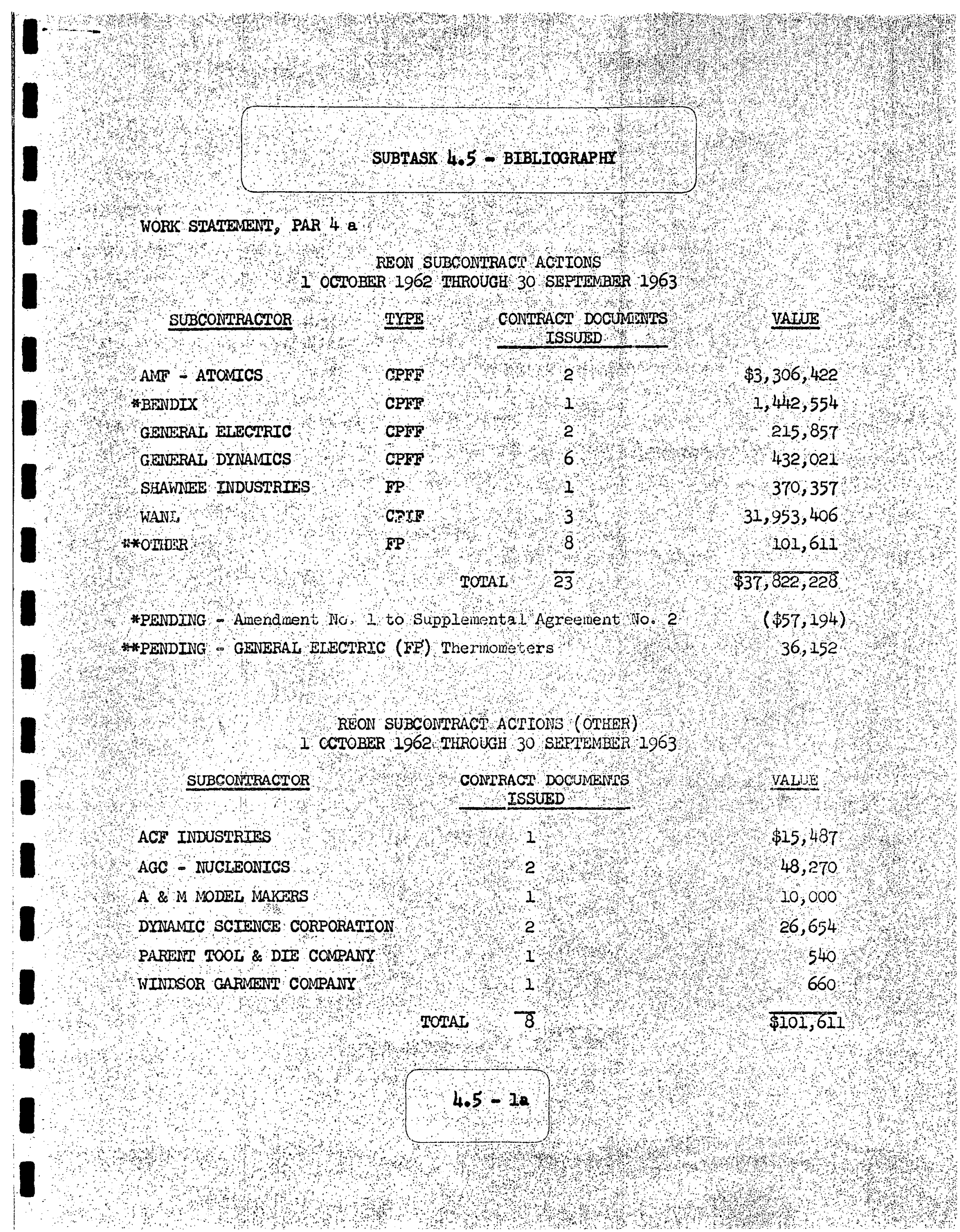


WORK STATEMUENT, PAR 4 c AND 4 e

FROCUREMTNT APPROVAL ACTION:

1 OCIOBER 1962 THROUGH 30 SEPITMMBER 1963

\begin{tabular}{|c|c|c|c|c|c|}
\hline \multicolumn{2}{|c|}{ ReceIved } & \multicolumn{2}{|c|}{ Pending } & \multicolumn{2}{|c|}{ Completed } \\
\hline No. & Value & Ne. & Value & No. & VaIue \\
\hline 36 & $\$ 804,926$ & 2 & $\$ 30,880$ & 34 & $\$ 664,750$ \\
\hline 10 & 95,970 & 2 & 23,741 & 8 & 72,229 \\
\hline 11 & 91,364 & 3 & 44,063 & 8 & 47,301 \\
\hline 85 & $1,948,964$ & 5 & 284,214 & 80 & $1,664,750$ \\
\hline 28 & 484,241 & 9 & 89,486 & 19 & 394,755 \\
\hline 4 & $7,448,447$ & $37^{*}$ & $1,662,342$ & 207 & $5,786,105$ \\
\hline & $\$ 10,873,912$ & 58 & $\$ 2,134,726$ & 356 & $\$ 8,739,186$ \\
\hline
\end{tabular}

th Awaiting Action $30^{\circ}$ Sept 63
11 - WANI Action
- \$806,566
11 - SIPO AC Action - 529,093
15 - AGC Action - 326,683
37
$\$ \overline{1,662,342}$ 


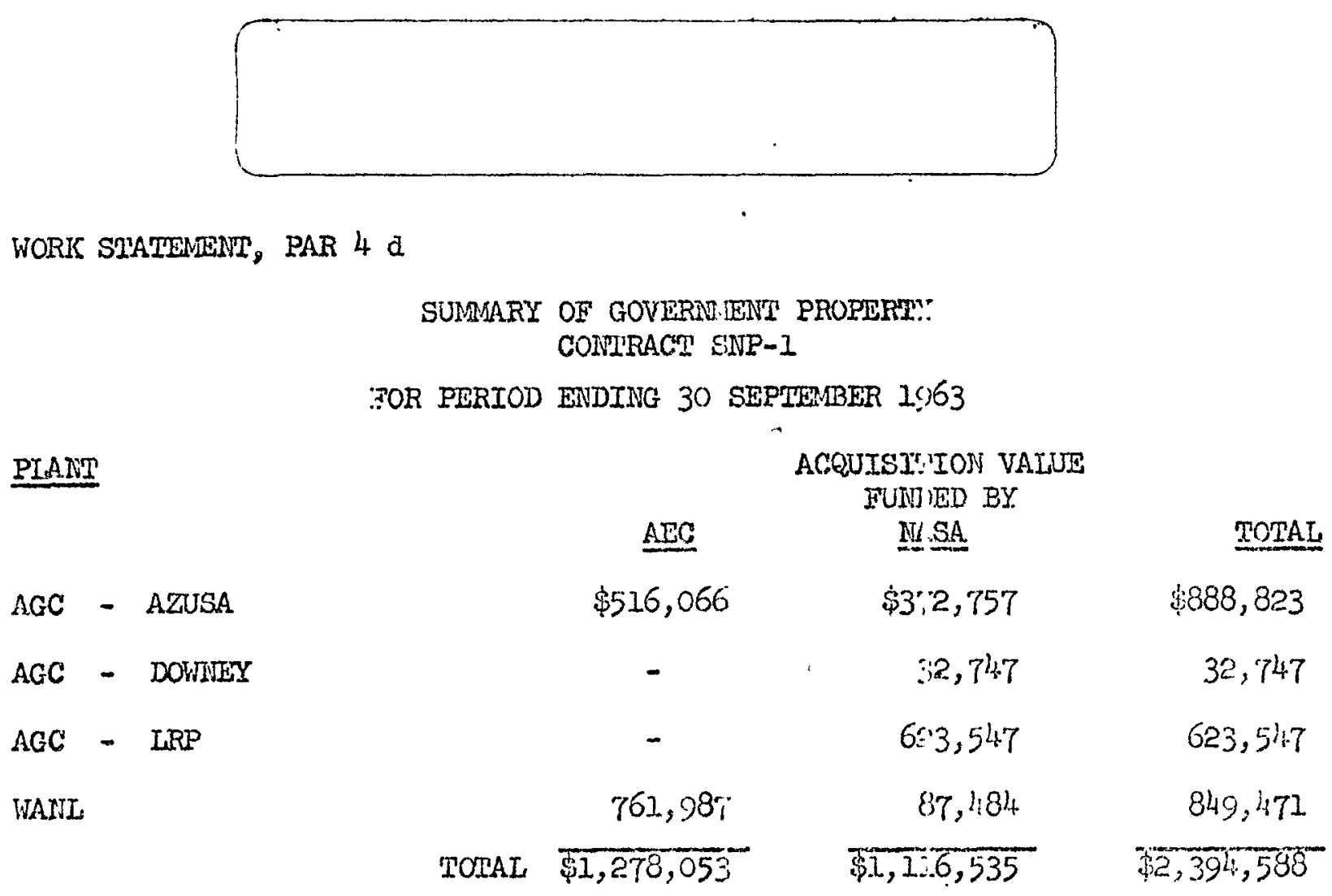

\section{SUMARY OP DEPRECIABIP GOVETMEITI (AEC) PROPERIY}

COMIUJACI SAP-I

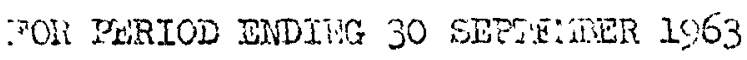

\begin{tabular}{|c|c|c|c|}
\hline Accountability & $\begin{array}{l}\text { Acquisition } \\
\text { Value }\end{array}$ & $\begin{array}{l}\text { Deprociation } \\
\text { Po Iote }\end{array}$ & $\begin{array}{c}\text { Jalroce } \\
\text { To Re Dropeiated }\end{array}$ \\
\hline AGC & $516,066.00$ & $\$ 97,020.41$ & $\$ 19,04.5 .59$ \\
\hline WANL & $202,968.85$ & $30,280 \cdot 30$ & $102,679.55$ \\
\hline
\end{tabular}




\section{S/T 4.6 SPECIAL PROGRAM SERVICES}

ACCOMPLISHMENTS

$W / s$

REFERENCE

PLANNED
1. CONSULTANTS FOR NAG
2.SPECIAL EQUIPMENT $\$$ SERVICES

ACTUAL

PROVIDED

PROVIDED
EVIDENCE OF COMPLETION

3 NAG MEETINGS

IN USE 
SUBTASK 4.6 - ACCOMPLISHMENTS FOR CY 1963

Purpose and Objective

1. Provide for nationally known consultants for the NERVA advisory group.

2. Provide special office equipment services. Accomplishments

1. Three NAG meetings were held during the year.

2. A Clary office computer with peripheral equipment has been in use throughout the year. 


\section{S/T 5.I PLANNED ACCOMPLISHMENTS}

W/S REF. 63002

2-5.1-I A\& B TEST STAND C-6 ALL EFFORT COMPLETED EXCEPT

$A$ (1) FAB \& INSTALL NOZZLE ADAPTER

DELETED DUE TO DIFFUSER DEFERRAL COOLANT SYSTEM

A \& B (3) COMPLETE CY 62 EFFORT

COMPLETE EXCEPT SS DIFFUSER

2-5.1-II A TEST STAND C-7 \& 8 ALL EFFORT COMPLETED EXCEPT

(3) FAB \& INSTALL VALVES FOR TPCV HOT

VALVE PROCURED TO BE INSTALLED GAS TEST

(6) ACTIVATE TSOV VESSEL \& NRX-ACFTS NOV. 1963

(7) ACTIVATE TSOV HOT GAS TEST SYSTEM TSOV COMP./NRX-A AWAITING NRX-A HDWARE

(8) COMPLETE CY 62 EFFORT VALVE PROCURED TO BE INSTALLED NOV 1963 COMPLETE EXCEPT $\mathrm{N}_{2}$ PRECHILL SYSTEM 2-5.1-II B TEST STAND C-7 \& 8 ALL EFFORT COMPLETED EXCEPT

(6) ACTIVATE NRX-A CFTS

WAITING NRX-A HARDWARE 
Purpose and Objective

The objective of Task Items 5.1 through 5.9 is to provide for continued design, procurement, fabrication and modification of the special test equipment required during CY 1963 in Test Zones C, G, H and the Cryogenic Laboratory in support of the NERVA R\&D test program in a timely manner consistent with the program test schedules and in compliance with all project requirements specified.

The objective of Task Item 6 is to provide G.F.E. for support of the NERVA R\&D test program. 
Purpose and Objective

See page 5-1.

Accomplishments

All work planned for the $\mathrm{C}$ area was completed except for the following

items:

$2-5 \cdot 1-I-A(I)$

Fabricate and Install Nozzle Adapter Coolant System

$\underline{2-5.1-I-A \& B(3)}$

The effort not completed in the above $\mathrm{W} / \mathrm{S}$ items relates to the supersonic diffuser effort for Test Stand C-6. This diffuser was planned for $\mathrm{C}-6$ nozzle skirt tests. Due to the fact that $H$ area will become available in time to accomplish this work, it is not planned to install a supersonic diffuser in the $\mathrm{C}-6$ area.

$\underline{2-5 \cdot 1-I I-A(3)}$

Fabricate and install valves for TPCV Hot Gas Drive

This valve was procured but has not been installed due to the urgency of TPA tests. Installation is planned for mid-November 1963.

$\underline{2-5.1-I I-A(6)}$

The TSOV vessel has been activated in Test Stand C-7, however the cold flow system for $\mathrm{C}-8$ is awaiting the delivery of the test hardware for final activation.

$\underline{2-5 \cdot I-I I-A(7)}$

The activation awaits the installation of the above valve and the receipt of Generation II TPCV for tests.

$\underline{2-5 \cdot I-I I-B(5)}$

The procurement of these transducers was transferred to sub-task 2.4. $\underline{2-5 \cdot 1-I I-B(6)}$

Awaiting NRX-A hardware. 
$2-5.1-I I-B(6)$ (cont.)

Work which has been accomplished under the above Subtask has involved the removal of STE from the C-6 area to make it available for nozzle testing. The C-8 area was modified to receive the Generation II engine simulator and this test system activated and the test completed. Work in Test Stand C-7 was involved first, in the modification of the test stant to provide hot gas drive to TPA and in August and early September the suction system was modified to install a TSOV vessel and simulated PFS suction piping for the TPA. This work was completed and the test stand reactivated. 


\section{[1] NERVA}

SCHEDULES AND MILESTONES

CONTRACT YEAR 1963

TASK ITEM 5.1

照

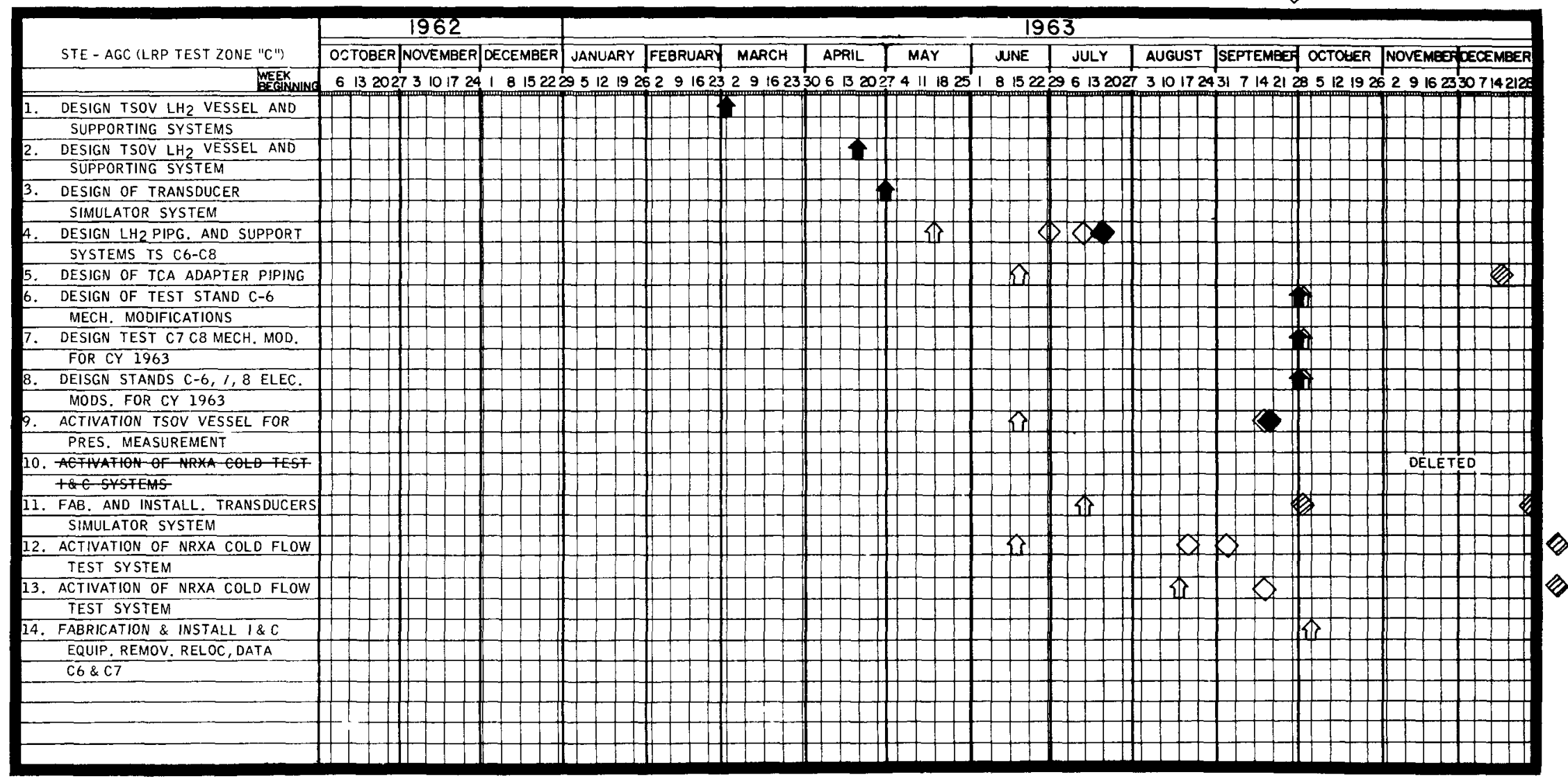

DATE:

仓 SCHEDULED MILESTONE

$\diamond$ RESCHEDULED MILESTONE

- MILESTONE ACHIEVEMENT

- Rescheduled milestone achievement

Oescheduled to cy 64

RE(P) 


\section{S/T 5.2 PLANNED hCCOMPLISHinENTS}

W/S REF. 63002

2-52 A CRYOGENICS LAB ALL EFFORT COMPLETE EXCEPT

(1) FAB EIINSTALL 2 BEARING TESTERS FOR

COMPLETE EXCEPT I FOR LAB \& LAB \& 5 FOR RET

3 FOR RET

(2) FAB \& INSTALL ENVIRONMENTAL CHAMBER COMPLETE $10-21-63$

(6) FAB \& INSTALL L $\mathrm{H}_{2}$ PIPING

$11-5-63$

(7) FAB \& INSTALL SIDE BY SIDE TEST SETUP 12-1-63

2-5.2B

(1) PROCURE \& INSTALL TRANSDUCERS 1-1-64

(2) PROCURE $\varepsilon_{2}$ INSTALL $\mathrm{H}_{2}$ LEAK MEASURING 11-2-63 APPARATUS 
Purpose and Objective

See page 5-1.

Accomplishments

$2-5.2 A(1)$

All effort to provide special test equipment to the Cryogenic Laboratory was completed except as follows:

$2-5.2 A(1)$

In CY63 two bearing testers were fabricated for RET and one for the laboratory. This reduction in work was brought about as a result of the deferral in the radiation test pallet schedule under Subtask 1.9 and as a result of fabrication and procurement delays of the bearing testers.

$\underline{2-5.2 A(2)}$

This work was completed in October rather than during the Contract Year as a result of procurement delays.

$\underline{2-5.2 A(6)}$

This effort will be completed early in Nuvember. The delay was caused by the concentration of effort in more critical areas. A portable $\mathrm{LH}_{2}$ dewar was employed to supply $\mathrm{LH}_{2}$ for the experiments being performed in the Cryogenic Laboratory.

$\underline{2-5.2 A(7)}$

This work statement item refers to a setup to checkout pallet No. 904 . The effort has been delayed as a result of a slippage of the pallet schedule. It is planned for completion early in December.

$2-5.2 B(1)$

This work has been completed with the exception of position, acceleration and load transducers which have not yet been delivered. This effort is scheduled for completion the first of January 1964. 


\section{$\underline{2-5.2 B(2)}$}

Due to procurement delays this apparatus arrived late and is being installed at the present time. It will be cumplete early in November.

Work has been completed during CY63 such that the Cryogenic Laboratory construction has been completed and the laboratory equipment installed and activated. This includes the environmental test chamber, electrical test setups, a TPCV test setup, TSOV setup, the installation and activation of the bearing tester and the checkout equipment for the radiation effects bearing testers. 


\section{WPROGA}

SCHEDULES AND MILESTONES

CONTRACT YEAR 1963

TASK ITEM 5.2

紧

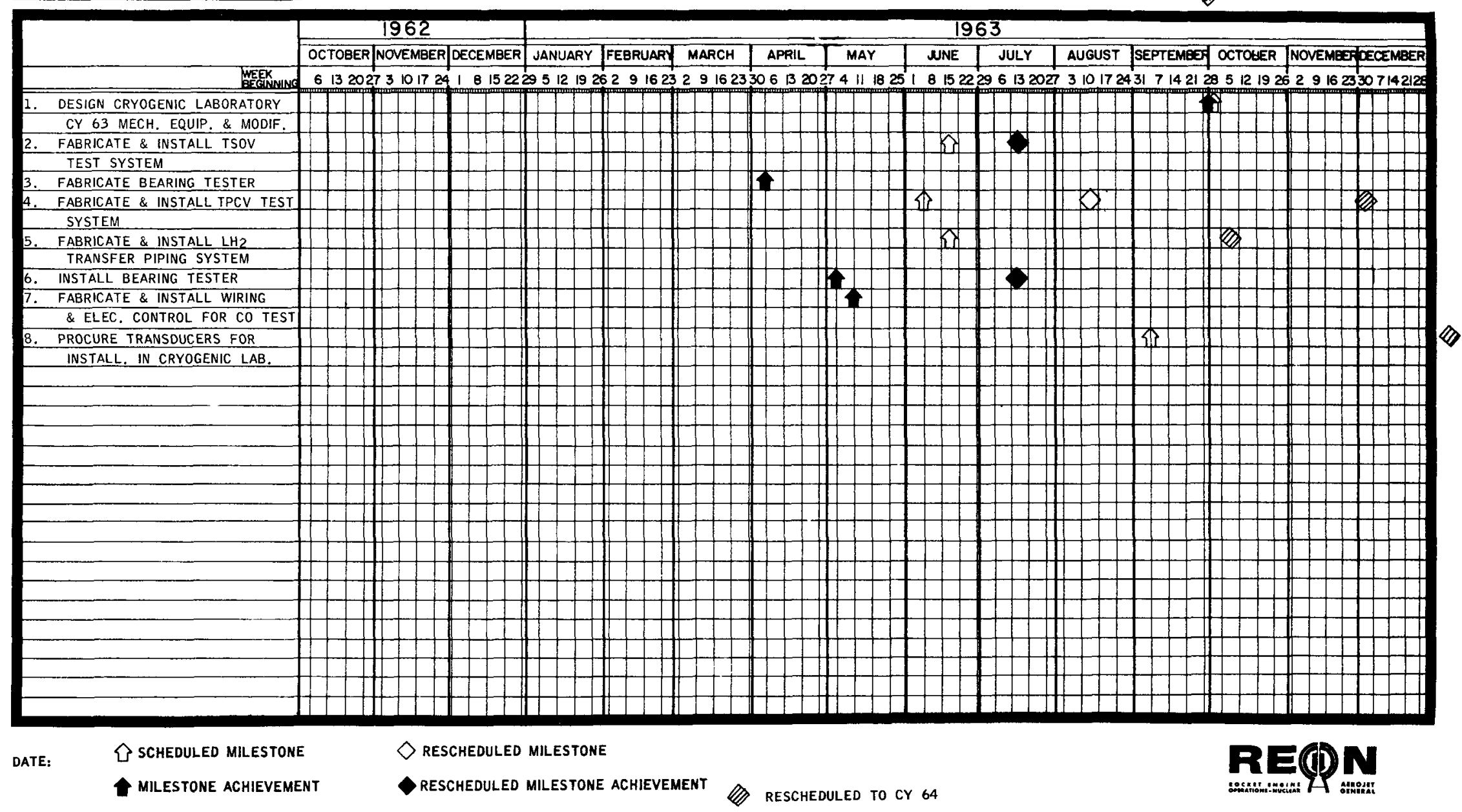




\section{S/T 5.3 PLANNIED ACCOIrPLISHImENTS}

W/S REF. 63002

2-5.3A TEST ZONE H ALL EFFORT COMPLETE EXCEPT

(1) FAB AND INSTALL WORK PLATFORMS

DELETED

(2) FAB 2 GG FOR TPA AND TPCV TESTS

GG PROCURED, NOT INSTALLED

(6) FAB AND INSTALL MAIN INJECTOR

(7) FAB AND INSTALL TURBINE EXHAUST EJECTOR

(8) FAB AND INSTALL $\mathrm{H}_{2}$ HEATER

(9) FAB AND INSTALL TPCV HOT H $\mathrm{H}_{2}$ TEST SETUP

(10) FAB AND INSTALL NOZZLE ADAPTER COOLANT SYS)

(II) ACTIVATE TEST ZONE H FACILITY

12/26/63 FOR H-4 1/10/64 FOR H-6

(13) FAB AND INSTALL VALVES FOR TPA HOT $\mathrm{H}_{2} \mathrm{O}$ SYS

(14) FAB AND INSTALL TSOV VESSEL (DELAYED FOR NOZZLE TESTING)

(15) REINFORCE H-4, $5 \$ 6$ FOR BLAST OVERPRESSURE

(16) MODIFY H-5 FOR NTS SUCTION LINE

(17) ACTIVATE TSOV, NTS SUCTION LINE DELAYED FOR NOZZLE TESTING DELAYED FOR NOZZLE TESTING DEFERRED 1/10/64 (DELAYED FOR NOZZLE TESTING) 


\section{S/T 5.3 PLANINED ACCOImPLISHmEITS}

2-5.3B TEST ZONE H ALL EFFORT COMPLETE EXCEPT

(1) FAB AND INSTALL EJECTOR ELECTRICAL SYSTEM

(3) PROCURE AND INSTALL C/O EQUIPMENT

(4) PROCURE AND INSTALL $X-Y$ PLOTTER

(5) ACTIVATE ZONE H FACILITY

(7) PROCURE \& INSTALL CFDTS DATA PROCESSING SYSTEM

(8) PROVIDE ELECTRICAL CONTROLS HOT GAS SYSTEM AND TSOV VESSEL

(9) PROCURE $\varepsilon_{2}$ INSTALL TRANSDUCERS FOR TSOV VESSEL

(10) ACTIVATE ELECTRICAL SYSTEM FOR HOT GAS SYSTEM AND TSOV VESSEL

(ii) FAB AND INSTALL TRANSDUCER SIMULATOR SYSTEM

(13) FAB AND INSTALL ENVIRONMENT TRANSDUCER CALIBRATION SYSTEM

(14) FAB AND INSTALL CRYOGENIC REF. JUCTION

(15) INSTALL TRANSDUCER CALIBRATION EQUIPMENT

(16) FAB AND INSTALL ELECTRICAL SYSTEM VH-12 AND TPCV TEST SYSTEM

DEFERRED

DELETED

DEFERRED

12-26-63 H-4/1-10-64 H-6 DEFERRED TO 6-30-64

$1-10-64$

$1-10-64$

$1-10-64$

DEFERRED

12-30-63

$11-30-63$

$12 \cdot 30-63$

$6-30-64$

CHART 4 
SUBTASK 5.3 - ACCOMPLISHMENTS FOR CY 1963

Purpose and Objective

See page 5-1.

Accomplishments

All effort in Test Zone H STE has been completed except:

$2-5 \cdot 3 A(1)$

This work was not accomplished in CY63 due to the concentration of effort on completing the assembly and activation of $H$ area test setups. $2-5 \cdot 3 A(2)$

The gas generators were procured but not installed.

2-5.3A(6) Fabricate and Install Main Ejector

2-5.3A(7) Fabricate and Install Turbine Exhaust Ejector

2-5.3A(8) Fabricate and Install H-2 Heater

2-5.3A(9) Fabricate and Install TPCV Hot $\mathrm{H}_{2}$ Test Setup

2-5.3A(10) Fabricate and Install Nozzle Adapter Coolant System

2-5.3A(13) Fabricate and Install Valves for TPA Hot Hydrogen System

2-5.3A(14) Fabricate and Install TSOV Vessel

2-5.3A(15) Reinforce $\mathrm{H}-4,5$ and 6 for Blast of Pressure

2-5.3A(17) Activate TSOV NTS Suction Line

2-5.3B(1) Fabricate and Install Ejector Electrical System

2-5.3B(8) Provide Electrical Control Hot Gas System and TSOV Vessel

2-5.3B(9) Procure and Install Transducers for TSOV Vessel

2-5.3B(10) Activate Electrical System for Hot Gas System and TSOV Vessel

2-5.3B(13) Fabricate and Install Environmental Transducer Calibration System

2-5.3B(14) Fabricate and Install Cryogenic Reference Junction

2-5.3B(15) Install Transducer Calibration Equipment 
The above items have been delayed due to several changes in $\mathrm{H}$ area activation plans. Due to the urgency of TPA testing required to meet the TPA 10-minute test milestone under Subtask 1.2, effort in the $\mathrm{H}$ area was directed toward the activition of $\mathrm{H}-6$ which would provide the only test setup where the liquid hydrogen run capabilities existed to meet the run requirements. As a result of concentration on activating $H-6$, plans were made to delay the availability of $\mathrm{H}-4$ for nozzle testing. Late in $\mathrm{CY} 63$ we were directed to make every effort to activate $\mathrm{H}-4$ area as early as possible in order that long duration runs on the nozzle would be possible. As a result, activation effort ill $H-0^{\circ}$ was discontinued and modifications necessary to the stand for activation of $\mathrm{H}-4$ area were begun. This stand will be available for test December 20, $190 ́ 3$ and H-́́ on January 10, 1964.

$\underline{2-5 \cdot 3 A(11)}$

The above effort was deferred as noted above. Activation of H-4 will be accomplished December 26, 1963 and activation of H-0 January 10, 1964.

2-5.3A(16) Modify H-5 for NTS Suction Line

2-5.3B(3) Procure and Install Checkout Equipment

2-5.3B(4) Procure and Install XY Plotter

$2-5 \cdot 3 B(7)$

The above work statement items have been deferred until approximately June 1964 as a result of the deferral of the cold flow development test system activation date. This modification in out plans was brought about by the requirement to make additional long duration nozzle test firings to verify the nozzle design. This work must be accomplished before shutdown of the $H$ area test stand for modification for the CFDTS.

The work which has been completed in CY63 in the $H$ area involves the completion of the test stand structure and liquid hydrogen supply tank. This tank has been checkout and is ready for activation. The liquid hydrogen storage vessels for $\mathrm{H}$ area have been installed and activated. A gaseous and liquid oxygen system has been installed and is ready for activation. The test stand I\&C has been installed. This includes a complex control system for the three test stands and a data processing system capable of handing the test data from any one of the three test stands.

$$
5 \cdot 3-2
$$




\section{(1)

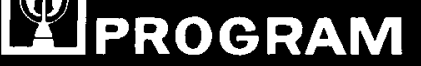

SCHEDULES AND MILESTONES

CONTRACT YEAR 1963

TASK ITEM 5.3

成

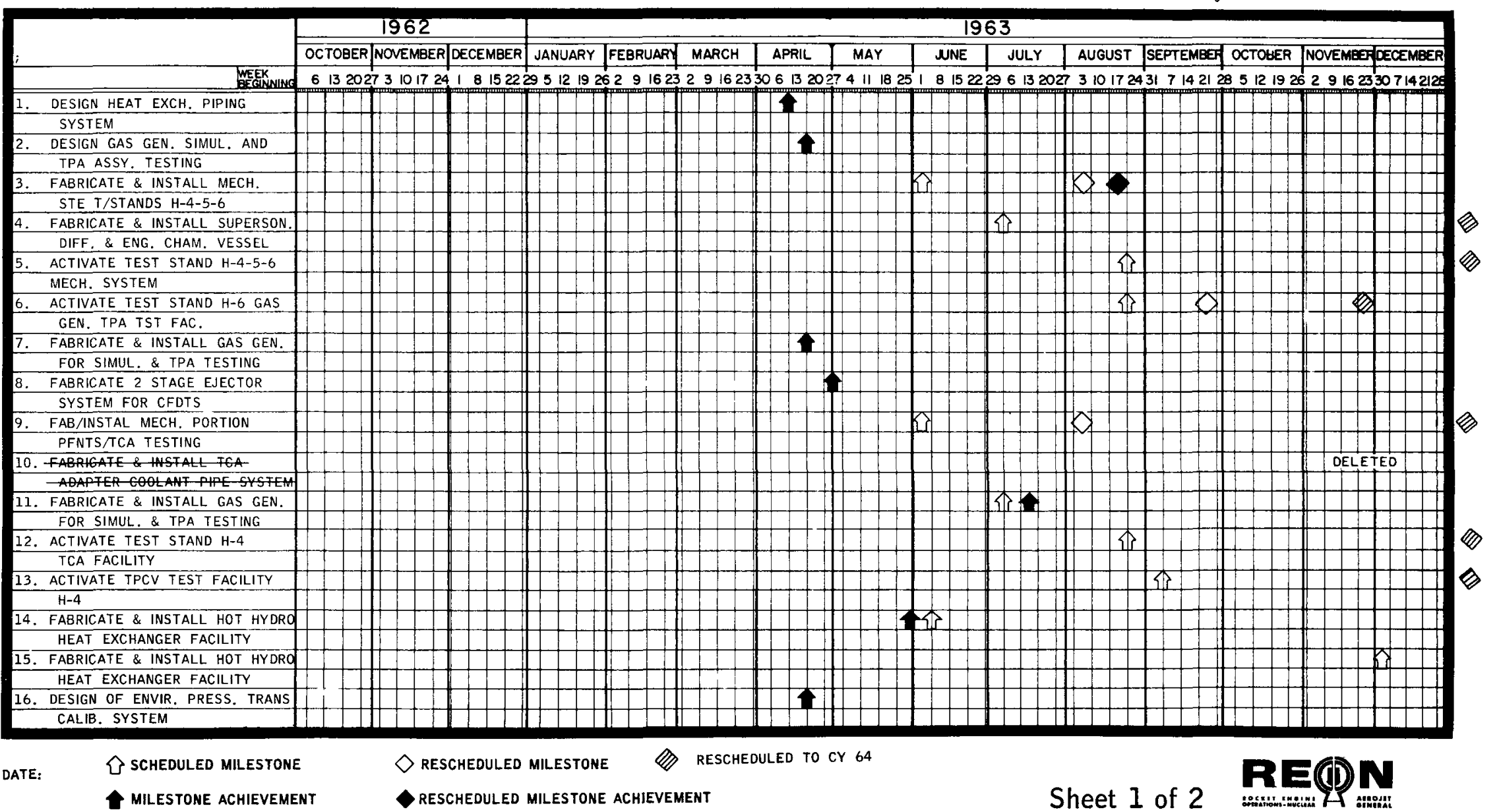

Sheet 1 of 2 . 


\section{(1) NERVA
PROGRAM}

SCHEDULES AND MILESTONES

CONTRACT YEAR 1963

TASK ITEM 5.3

感

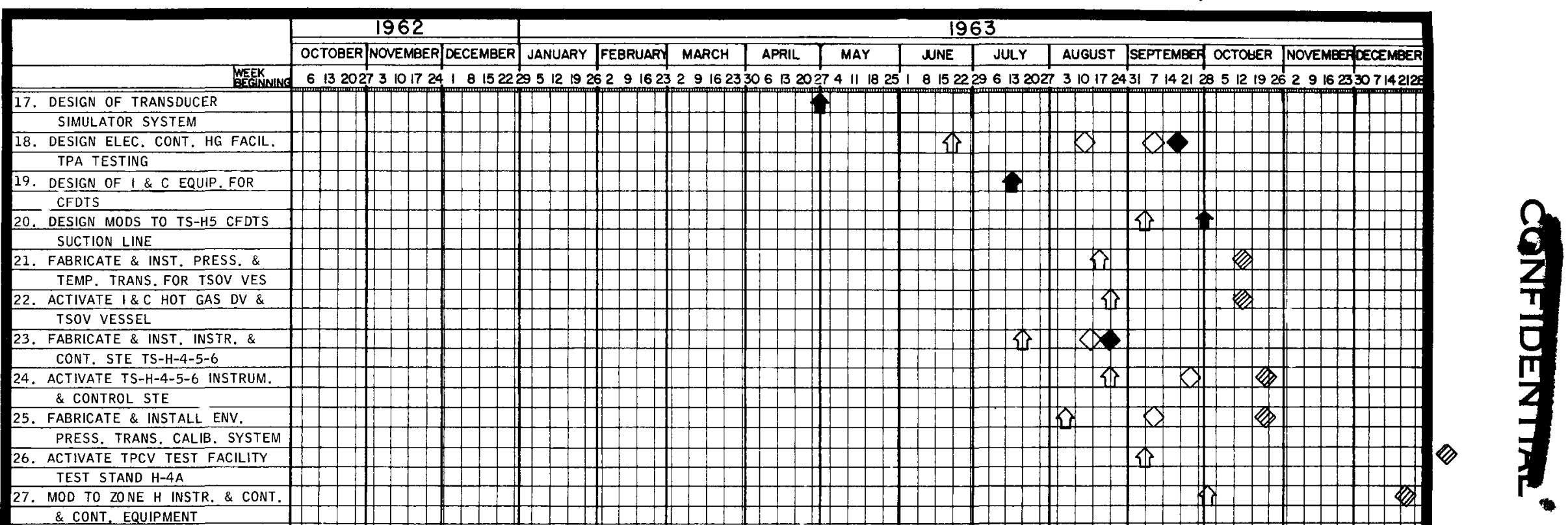

DATE:

S SCHEDULED MILESTONE

$\bigcirc$ RESCHEDULED MILESTONE

Reschedule to Cy 64

- MLLESTONE ACHEVEEMENT

$\checkmark$ ReSCHEDULED MLLESTONE ACHIEVEMENT

Sheet 2 of 2 RE(D) 


\section{TASK ITEM 5.4}

\section{ACCOMPLISHMENTS}

\begin{tabular}{|c|c|c|c|c|}
\hline \multicolumn{2}{|c|}{$\begin{array}{c}W / S \\
\text { REFERENCE }\end{array}$} & PLANNED & \multirow{2}{*}{$\begin{array}{l}\text { ACTUAL } \\
\text { COMPLETE }\end{array}$} & \multirow{2}{*}{$\begin{array}{l}\text { EVIDENCE OF } \\
\text { COMPLETION } \\
\text { P.0. } 353687\end{array}$} \\
\hline $2-5.4$ & (1) & $\begin{array}{l}\text { PROCURE } 25 \text { DUAL AMPLIFIERS FOR PACE } \\
\text { CONSOLE } 231 \mathrm{R}\end{array}$ & & \\
\hline & (2) & $\begin{array}{l}\text { PROCURE } 20 \text { SETS OF MULTIPLIER CARDS } \\
\text { FOR PACE CONSOLE } 231 \mathrm{R}\end{array}$ & COMPLETE & P.O. 360337 \\
\hline & (3) & $\begin{array}{l}\text { PROCURE A I2-CHANNEL DIRECT WRITING } \\
\text { RECORDER FOR CFDTS }\end{array}$ & COMPLETE & $\begin{array}{l}\text { PROCURED 8-CHANNEL; } \\
\text { SNPI-A-NAS-087 }\end{array}$ \\
\hline & (4) & $\begin{array}{l}\text { COMPLETE MODIFICATION OF THREE AEC-OWNED } \\
\text { SINGLE CONSOLES FOR SIMULATED ENGINE TESTING }\end{array}$ & $\begin{array}{l}2 \text { COMPLETED; } \\
\text { THIRD SCHEDULED } \\
\text { COMPLETE IN JAN. }\end{array}$ & P.0. 350339 \\
\hline & (5) & $\begin{array}{l}\text { PROCURE CHECKOUT AND HARDWARE TIE-IN } \\
\text { EQUIPMENT }\end{array}$ & COMPLETE & $\begin{array}{l}\text { INVENTORY OF GOVT. } \\
\text { PLANT EQUIPMENT } \\
\text { I4OCT } 63 \text {; PAGES } \\
301 \text { TO } 303 \\
\text { INCLUSIVE }\end{array}$ \\
\hline
\end{tabular}


Purpose and Objective

The overall objective of this subtask was to support the controls effort of $\mathrm{S} / \mathrm{T}$ 1.5, and the materials effort conducted under S/T 1.9. Specifically, the objectives were:

1. To modify and add to the analog computing equipment to provide an adequate system for engine simulation testing, and

2. To fabricate special equipment required to conduct materials thermal cunductivity and tensile tests in a radiation environment.

In Subtask 5.4, the procurement of all the STE has been completed and delivery made except for the modification of one of the analog computer consoles. This modification is under contract to Comcor, and completion is rescheduled to January 1964.

$\underline{2-5.4}$

A. In support of the systems analysis and controls program, the following work was performed:

1. The additional amplifiers to complete the full complement of the $231 \mathrm{R}$ console have been procured and have been in-house since the spring of 1963.

2. The multiplier cards to expand to the full complement of the $231 \mathrm{R}$ console have been procured and have been in use since mid-summer.

3. The procurement of a l2-channel direct writing recorder was changed to an 8-channel recorder due to a re-evaluation of paper size and the handling of the records. Also, upon re-evaluation it was decided that 8 channels of recording were adequate for the job. Another important factor in this consideration is that the paper on an 8-channel recorder does not creep like it does on the 12-channel recorder evaluated.

4. Two of the modified consoles have been integrated into the PACE computer complex. During the installation of these consoles cunsiderable problems occurred in that noise on the power supple lines and amplifiers was increased intolerably when the consoles were connected into the complete computer installation. 
5. The checkout and hardware tie-in equipment is in-house and has been in use for sometime.

B. In support of the materials rudiation effects program, the following was performed.

1. A prototype thermal conductivity test apparatus was provided, and a demonstration test was completed. The remaining ten test units were manufactured but not assembled. Completion of these equipment will occur in contract year 1964. The test date is scheduled for June 1964. This work is being rescheduled to be compatible with the rescheduling of the materials radiation tests at General Dynamics, Fort Worth.

\section{All shear test fixtures and sub-size tensile test fixtures were} completed and the shear test fixtures utilized for control tests.

As you can see from the milepost charts just handed you, five out of the seven milestones were completed; of the two milestones deferred, milestone No. 3 was deferred to contract year 1964 in order to allow maximum utilization of the PACE computer for solution of power range and cooldown problems. Wilestone No. 7 was deferred to contract year 1964 to be compatible with the rescheduling of the materials program.

\section{Conclusions}

The objectives of this subtask, i.e., to support the controls effort and the materials effort, were met in a manner that allowed the most effort under the development subtasks to proceed as required, without any penalty in cost or schedule being imposed. 


\title{
Q19ERVA
}

SCHEDULES AND MILESTONES

CONTRACT YEAR 1963

TASK ITEM 5.4

灵

STE - AGC (AZUSA PLANT) ANALOG COMPUTER

\begin{abstract}
1962
\end{abstract}
1963

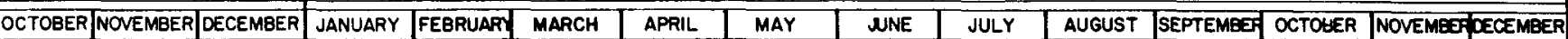

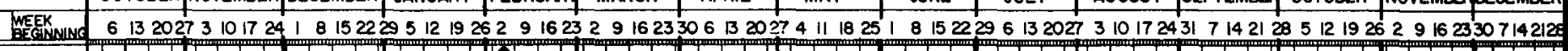

1. PACE $231 \mathrm{R}$ CONSOLE RECEIVED

MODERNIZATION PACE 24D

COMPLETE

MODERNIZATION PACE 131R COMPLETE

DELIVER 231R ADDITIONAL

DELIVER CONTROL SYSTEM C/O

EQUIPMENT

PROTOTYPE THERMAL CONDUCTI-

TMER EQUPDOCTIVITY EQUIPMEN

THERML CONDUCTIVITY EQUI

DYNAMICS/FT. WORTH

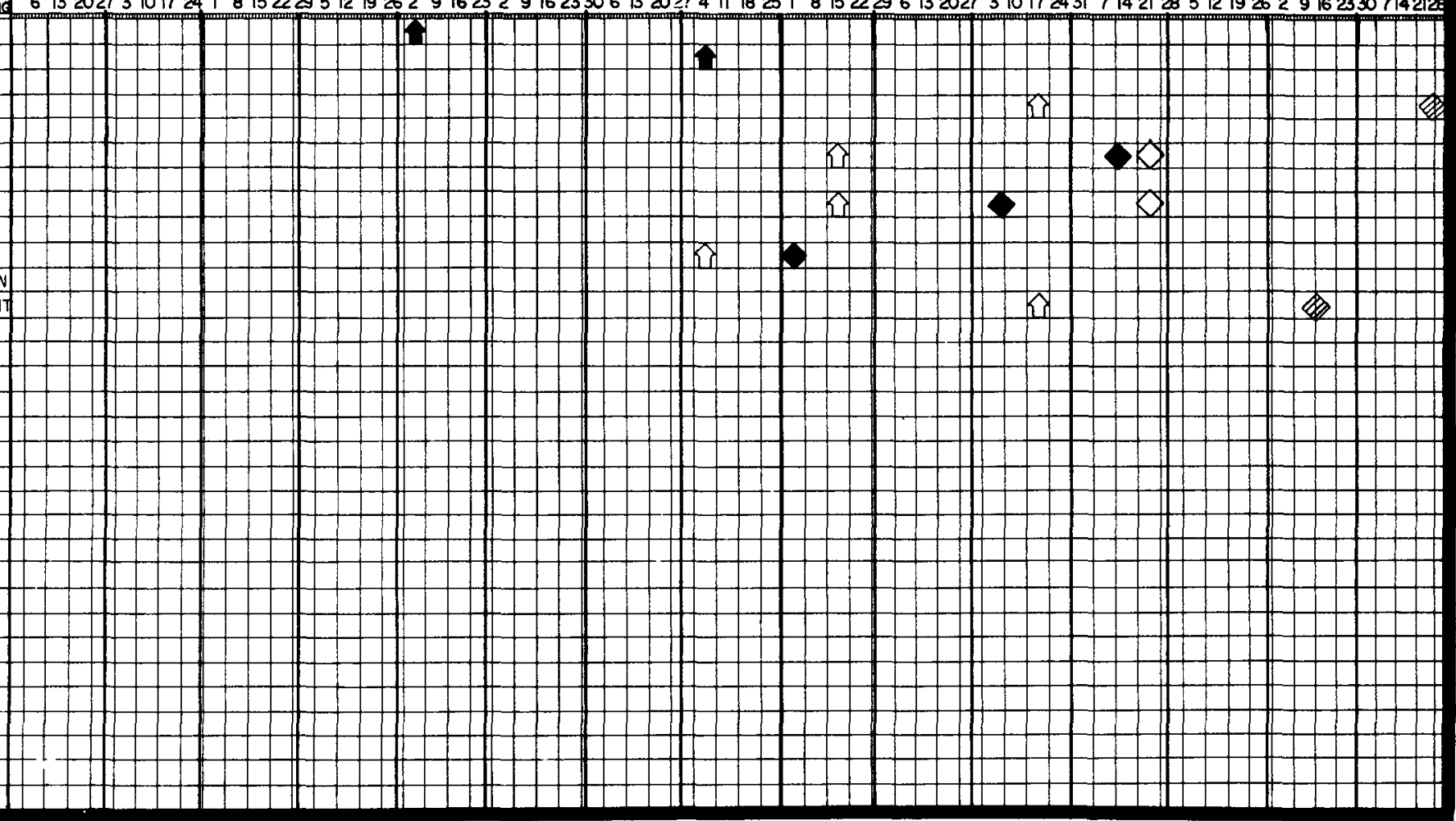

DATE:

$\checkmark$ SCHEDULED MILESTONE

$\diamond$ RESCHEDULED MILESTONE

RESCHEDULED MILESTONE ACHIEVEMENT

RESCHEDULED TO CY 64

RE(D) 


\section{S/T 5.5 SPECIAL TEST EQUIPMENT \\ ACCOMPLISHMENTS}

$W / S$

REFERENCE 2-5.5 (I) Al

2 MODIFY TEST BUILDING AND INSTRUMENT CUBICLES

3 MODIFY MECHANICAL TEST EQUIPMENT (E.G. TARGET DOLLY)

BI INSTALL INSTRUMENTATION CONTROL CONSOLES

2 INSTALL ELECTRICAL COMPONENTS

\begin{tabular}{ll} 
ACTUAL & $\begin{array}{l}\text { EVIDENCE OF } \\
\text { COMPLETION }\end{array}$ \\
\cline { 2 - 2 } & $\begin{array}{l}\text { DNY 0716-16(09) } \\
\text { MP/JUNE PG } 12\end{array}$ \\
DELETED & $\begin{array}{l}\text { NOT NEEDED- } \\
\text { GFTF ACTIVATION }\end{array}$ \\
COMPLETED & DWGS-511634A \\
& -512610
\end{tabular}

DELETED

NOT NEEDED-TESTS PERFORMED AT CHINO HILLS OR GFT FACILITIES

DELETED
NOT NEEDED-TESTS PERFORMED AT CHINO HILLS OR GFT FACILITIES 


\section{S/T 5.5 SPECIAL TEST EQUIPMENT}

ACCOMPLISHMENTS

\begin{tabular}{|c|c|c|c|}
\hline $\begin{array}{c}w / s \\
\text { REFERENCE }\end{array}$ & PLANNED & ACTUAL & $\begin{array}{l}\text { EVIDENCE OF } \\
\text { COMPLETION }\end{array}$ \\
\hline $2-5.5$ (1) B3 & MODIFY INSTRUMENTATION & DELETED & $\begin{array}{l}\text { NOT NEEDED - TESTS } \\
\text { PERFORMED AT CHINO } \\
\text { HILLS OR GFT } \\
\text { FACILITIES }\end{array}$ \\
\hline $2-5.5$ (II) $\mathrm{Al}$ & PREPARE TESTING AREAS & COMPLETED & $\begin{array}{l}\text { PR } 175621 \text { - NEDS } \\
\text { DOWNEY } \\
\text { PO } 706179 C D \text {-NEDS } \\
\text { DOWNEY }\end{array}$ \\
\hline 2 & FABRICATE TEST STANDS & COMPLETED & $\begin{array}{l}\text { DY } 0716-16(02) \mathrm{MP} / \\
\text { NOV } 1962 \text { PG } 40 \\
\text { DY } 0716-16\left(0^{\circ}\right) \mathrm{MP} / \\
\text { DEC } 1962 \text { PG } 56\end{array}$ \\
\hline
\end{tabular}




\section{S/T 5.5 SPECIAL TEST EQUIPMENT}

ACCOMPLISHMENTS

\begin{tabular}{|c|c|c|c|}
\hline $\begin{array}{c}w / s \\
\text { REFERENCE }\end{array}$ & PLANNED & ACTUAL & $\begin{array}{l}\text { EVIDENCE OF } \\
\text { COMPLETION }\end{array}$ \\
\hline $2-5.5(11) A 3$ & MODIFY TEST BUILDINGS & DELETED & $\begin{array}{l}\text { NOT REQUIRED- } \\
\text { EXISTING FACILITIES } \\
\text { PROVED ADEQUATE } \\
\text { FOR PARTICULAR } \\
\text { TESTS CONDUCTED }\end{array}$ \\
\hline 4 & $\begin{array}{l}\text { TEST SETUP MODIFICATIONS } \\
\text { (E.G. WATER TANK AERATION SET-UP) }\end{array}$ & COMPLETED & $\begin{array}{l}\text { DY 0716-16(10) MP/ } \\
\text { JULY } 1963 \text { PG } 10\end{array}$ \\
\hline$B(1)$ & $\begin{array}{l}\text { INSTALL ELECTRONIC CONTROL UNITS } \\
\text { (E.G. OSCILLOSCOPES, POWER SUPPLY UNIT) }\end{array}$ & COMPLETED & $\begin{array}{l}\text { PO } 445091-C D \text {, } \\
\text { PO } 443054-C D \text {, } \\
\text { PO } 448496-C D\end{array}$ \\
\hline (2) & $\begin{array}{l}\text { MODIFY TEST INSTRUMENTATION } \\
\text { (EG. TIME DELAY GENERATOR, RESET } \\
\text { GENERATOR, PROBE \& PASSIVE TERMINATION) }\end{array}$ & COMPLETED & $\begin{array}{l}\text { PO } 445094-C D \text {, } \\
\text { PO } 444857-C D \text {, } \\
\text { PO } 444855-C D \text {, } \\
\text { PO } 444854-C D\end{array}$ \\
\hline
\end{tabular}




\section{S/T 5.5 SPECIAL TEST EQUIPMENT}

ACCOMPLISHMENTS

\begin{tabular}{|c|c|c|c|}
\hline $\begin{array}{l}W / S \\
\text { REFERENCE } \\
\end{array}$ & PLANNED & ACTUAL & $\begin{array}{l}\text { EVIDENCE OF } \\
\text { COMPLETION }\end{array}$ \\
\hline $2-5.5$ (II) A(I) & PREPARE TEST SITE & COMPLETED & $\begin{array}{l}\text { H-NAD CHARGES } \\
\text { SUBMITTED TO SNPO-C }\end{array}$ \\
\hline (2) & FAB TEST STANDS & COMPLETED & $\begin{array}{l}\text { DYO716-16(05)MP FEB } \\
1963 \text { PG 129 } \\
\text { DYO716-16(06)MP MAR } \\
1963 \text { PG 107 } \\
\text { DYO716-16(10)MP } \\
\text { JULY } 1963 \text { PG } 41\end{array}$ \\
\hline (3) & $\begin{array}{l}\text { MODIFY TEST HARDWARE TO ACCOMMODATE } \\
\text { CHANGES (E.G.5O FT TEST STAND) }\end{array}$ & COMPLETED & РНОТО 96318814 \\
\hline$B(1)$ & $\begin{array}{l}\text { PROVIDE INSTRUMENTATION AND CONTROL } \\
\text { DEVICES }\end{array}$ & COMPLETED & $\begin{array}{l}\text { REON RPT NO. } 2597 \\
\text { PG } 107\end{array}$ \\
\hline
\end{tabular}




\section{S/T 5.5 SPECIAL TEST EQUIPMENT}

ACCOMPLISHMENTS

\begin{tabular}{|c|c|c|c|}
\hline $\begin{array}{c}W / S \\
\text { REFERENCE } \\
\end{array}$ & PLANNED & ACTUAL & $\begin{array}{l}\text { EVIDENCE OF } \\
\text { COMPLETION }\end{array}$ \\
\hline $2-5.5$ (III) $B(2)$ & $\begin{array}{l}\text { PROVIDE MODIFICATION FOR INSTRUMENTATION } \\
\text { CHANGES }\end{array}$ & COMPLETED & $\begin{array}{l}\text { DY 0716-16(10) MP } \\
\text { JULY } 1963 \text { PG } 44\end{array}$ \\
\hline (3) & PROVIDE METEOROLOGICAL INSTRUMENTS & $\begin{array}{l}\text { DEFERRED TO } \\
\text { CY } 1964\end{array}$ & $\begin{array}{l}\text { ALL ITEMS PURCHASED } \\
\text { AND RECEIVED EXCEPT } \\
\text { FOR PIBAL THEODOLETE } \\
\text { AND WIND TELEMETRY } \\
\text { EQUIPMENT. DELAY IN } \\
\text { RECEIVING INFORMATION } \\
\text { ON EXACT EQUIPMENT } \\
\text { REQUIRED BY U.S. } \\
\text { WEATHER BUREAU, } \\
\text { LAS VEGAS, } \\
\text { NEVADA }\end{array}$ \\
\hline
\end{tabular}




\section{Purpose and Objective}

The objective of this subtask is to provide the special test equipment needed at Downey, Chino Hills, or the Garfield Flats Test Facility in support of Subtask 1.6 Destruct System Program.

$$
\text { Specific objectives for CY } 63 \text { were to procure items of mechanical, }
$$
photographic, instrumentation, and control equipment, meteorological equipment, and radiological equipment as dictated by the requirements of the various test programs.

$\underline{2-5.5(1) A 1}$

Support and individual test equipment for destruct system qualification and evaluation at the Downey Facility was fabricated. This equipment included target stands, barricades for cameras, and special equipment for the shipment of targets.

$\underline{2-5.5(I) A 2}$

The modifications of the test building and instrument cubicles for installation of the test equipment at the Downey Facility

This requirement was deleted. The activation cf Garfield Flats Test Facility precluded the necessity for these modifications.

$\underline{2-5.5(I) A 3}$

Provide modifications tc accommodate continuing test hardware configuration charges.

This item was completed. The target shipping dollies were modified to handle the more accurately simulated engine targets as required. $2-5.5(I) B I$

(I) $\mathrm{B2}$

(I)B3

These items or work were not performed since other AGC facilities became available to support the test program.

$2-5.5(I I) A I$

The testing areas for explosive concept evaluations at the Chino Hills Facility were prepared.

$$
5 \cdot 5-1
$$


This preparation included black topping of a test area to facilitate recovery of fragments for data recording.

$\underline{2-5.5(I I) A 2}$

Test stands and support units at the Chino Hills Facility were fabricated for the concrete-filled targets used in the development and evaluation tests of explosive charges and ccnfigurations.

$2-3.5$ (II) A3

Test buildings for the installation of $\mathrm{S} \perp \mathrm{E}$ required for evaluation and qualification studies at the Chino Hills Facility were not performed since existing test buildings proved to be adequate for the installation of STs for test data recording.

$\underline{2-5.5(I I) A 4}$

The water tank at Chino Hills Facility was modified, to provide a means of fragment recovery for the support research program studies concerned with graphite rod and B-it fuel element fracture mechanisms.

$\underline{2-5.5(I I) B I}$

Firing units, power supply units and oscilloscopes were installed at the Chino Hills Facility in barricaded locations for the conauct of explosive and fragmentation tests.

$\underline{2-5.5(I I) B 2}$

Time delay generators, reset generators, and other electronic components were installed in special circuits and modified as necessary to record applicable data at the Chino Hills Facility.

$2-5.5(I I I) A I$

Individual test sites adequate to accommodate the experiment assemblies to be evaluated and to allow for instrumented analysis at GFTF were provided. $\underline{2-5.5(I I) A 2}$

Test fixtures and stands to support the experimental assemblies to be evaluated were fabricated and installed at GFTF. 
$2-5.5$ (II)A3

A 50-ft test stand was installed and braced for a special test in September 1963. This involved modification of existing test stands to reach the elevation required. Dravo-Transportainers were modified and installed in a remote location for use as storage magazines.

$2-5.5$ (III)BI

Instrumentation such as oscilloscopes was provided to collect and record necessary data. Firing panels were installed to ensure adequate control over explosive firings during test operations. $2-5.5(I I I) B 2$

Firing panels and time-delay generators were connected in special circuits to provide the means of introducing known time delays between the firings of various explosive charges in a target. $2-5.5$ (III)B3

Meteorological instruments and facility required to predict fallout of test particles at GITF were procured.

All equipment items have been received except for a theodolite and three-wind recording-telemetry system. Purchases of the latter equipment were delayed pending receipt of exact equipment requirements from the U.S. Weather Bureau, Las Vegas, Nevada.

Conclusions

Five milestones were scheduled for completion in CY 63. Four of the five milestones were achieved as scheduled. One milestone was deferred into CY 64.

All special test equipment was procured and has been used except for four items of meteorological equipment. These include a theodolite and three-wind telemetry system for use at Hawthorne, Nevada. These items are on order and will be delivered in cy 64.

The delay in receipt of this equipment had no effect on the program progress since the CY 1963 testing was limited to unfueled targets. 
I. PURCHASE ORDERS AND CONTRACTS

A. TURCILASE ORDERS

1. Install Electronic Control Units

P.0. 445091-CD

2. Install Electronic Control Units

P.0. $443054-C D$

3. Install Electronic Control Units

P.0. 448495-CD

4. Modify Test Instrumentation

P.0. 445094-CD

5. Modify Test Instrumentation

P.0. 444857-CD

6. Modify Test Instrumentation

P.0. 444855-CD

7. Modify Test Instrumentation

P.0. 444854-CD

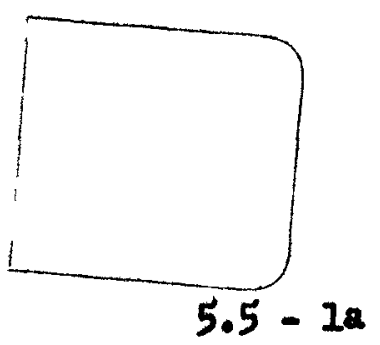




\section{NERVA
PROGRAM}

SCHEDULES AND MILESTONES

CONTRACT YEAR 1963

TASK ITEM 5.5

感

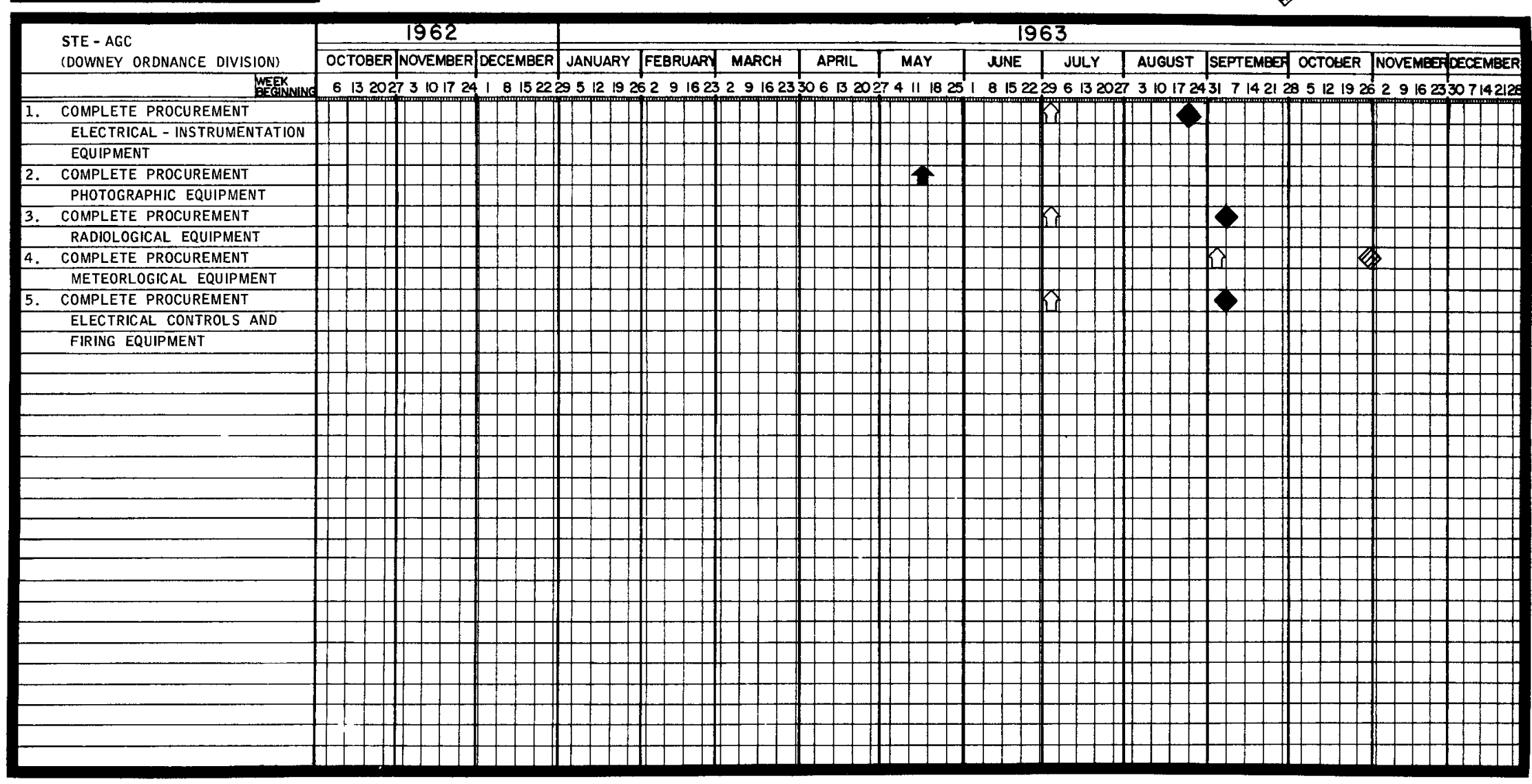

DATE:

S SCHEDULED MILESTONE

$\bigcirc$ RESCHEDULED MILESTONE

CILESTONE ACHIEVEMENT

- RESCHEDULED MILESTONE ACHIEVEMENT

Rescheduled to $\mathrm{CY} 64$

RE(D) $N$ 


\section{SUBTASK 5.7 - ACCOMPLISHMENTS FOR CY 1963}

Purpose and Objective

See page 5-1.

Accomplishments

The effort under this subtask is associated with the modification and maintenance of special test equipment necessary to support turbine drive bearing tester. This work was completed in the year. 


\section{S/T 5.75 .96 .1 \& 6.2 PLnNNWED hCCOMPLISHmENTS}

2-5.7 A AND B TEST ZONE G ALL EFFORT COMPLETED

2-59 A MISC. NON-TEST AREA LABORATORIES ALL EFFORT COMPLETED EXCEPT

(1) FAB AND INSTALL EXTENSION OF LN 2 PIPING DEFERRED

$2-5.9 B$

(2) COMPOSITE CY 62 I \& C EFFORT

COMPOSITE EXCEPT FOR CALIBRATION CRYOSTAT $1-1-64$

2-6.1 A ZONE H GFE ALL EFFORT COMPLETED

2-6.2 A AND B CRYOGENICS LAB GFE ALL EFFORT COMPLETED EXCEPT

(1) FAB AND INSTALL LN 2 PIPING SYSTEM $11-9-63$ 


\section{SUBTASK 5.9 - ACCOMPLISHMENTS FOR CY 1963}

Purpose and Objective

See page 5-1.

Accomplishments

All effort was completed with the exception of the following:

Fabricate and Install Extension of Liquid Nitrogen Piping

This effort was delayed due to late procurement and subcontractor difficulty in obtaining material.

$2-5.9 B(2)$

This work has been completed in its entirety except for the provision of a calibration cryostat which is due January 1, 1964. Incidentally, in RN63002 the TAD is in error in that this item is included under Subtask 5.8 rather than 5.9 .

The work under this subtask which has been accomplished involves the installation of an environmental chamber and fabrication equipment in the electrical test laboratory. This work has been completed and the equipment is installed and has been activated. 


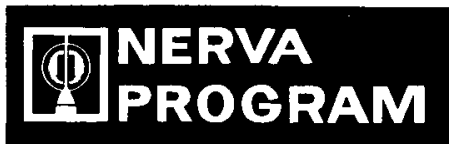

SCHEDULES AND MILESTONES

CONTRACT YEAR 1963

TASK ITEM 5.9

㘳

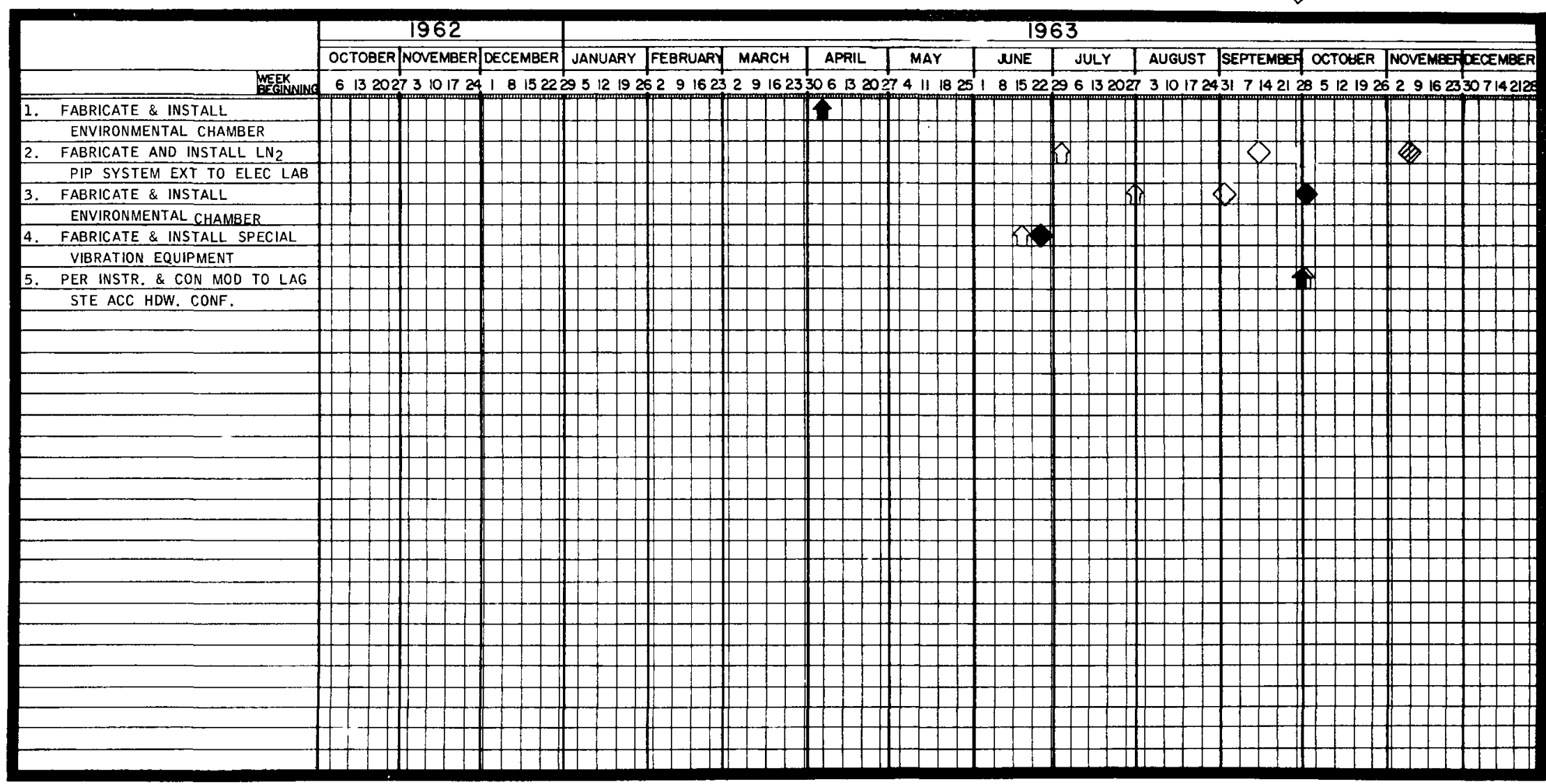

DATE:

S SCHEDULED MILESTONE

$\bigcirc$ RESCHEDULED MILESTONE

- MILestone ACHIEVEMENT

RESCHEDULEO MILESTONE ACHIEVEMENT

Rescheduled to cy 64

RE(D) 


\section{SUBTASK 6.1 - ACCOMPLISHMENTS FOR CY 1963}

Purpose and Objective

See page 5-1.

Accomplishments

This item involved the installation of a liquid hydrogen pump and vaporizer for the $H$ area. This equipment has been installed and activated. 
Purpose and Objective

See page 5-1.

Accomplishments

This effort has been completed except for the following:

$\underline{2-6.2 A(1)}$

This work will be completed early in November. It was delayed as a result of late procurement and the contractor's difficulty in obtaining material.

The work which was accomplished in CY63 under this item was the installation and activation of a humidity chamber, the installation and activation of a gaseous hydrogen and nitrogen transfer piping system for the Cryogenic Laboratory, the installation of a variable frequency power supply for the bearing tester and the installation of an oscillograph record scanner, two mass spectrometer leak detectors and various power supply and instrument items. 


\section{TipRoGA}

SCHEDULES AND MILESTONES

CONTRACT YEAR 1963

TASK ITEM 6.2

踏

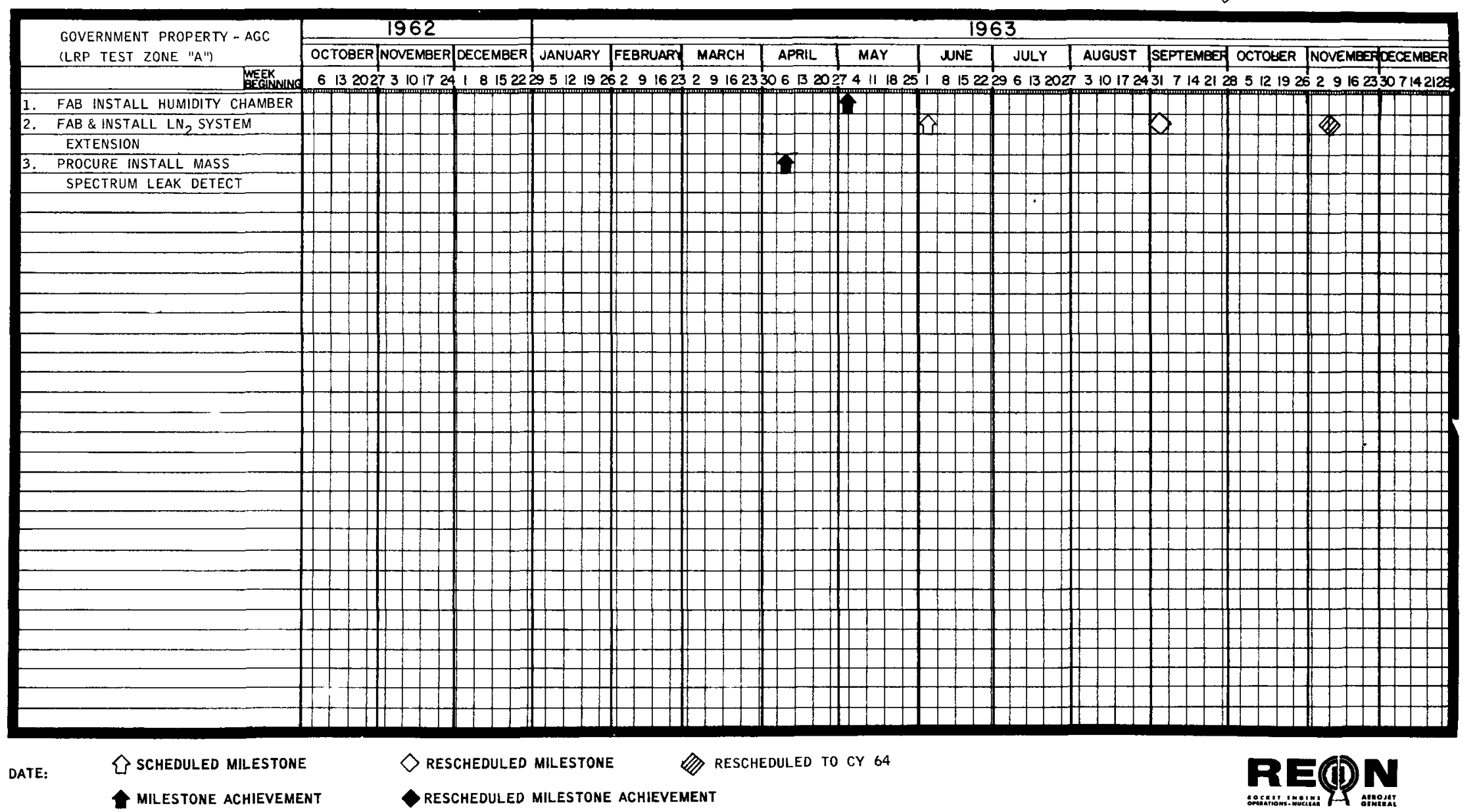




\section{MEMO}

To: Recipients of Report RN-S-0014

From: REON Documentation

Subject: Supplement to Report RN-S-0014

The attached material represents the contribution of Mr. W. D. Stinnett to the second portion of the NERVA presentation to SNPO-C on $30-31$ October 1963. At the time of the publication of RN-S-0014, the attached material was not available for inclusion. For the proper sequence it should be inserted in Vol. II of $\mathrm{RN}-\mathrm{S}-0014$ directly preceeding section "D Summary."

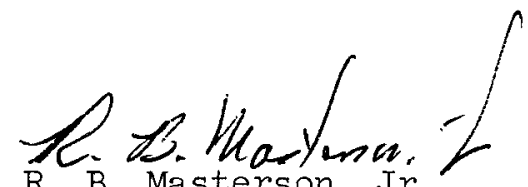


TECHNICAL PROGRAM SUMMARY

You have heard a lot of detail during 12 hours of presentations that has indicated the magnitude of the effort of the SNP-1 Contract Year 1963 program. I would like to summarize the significant accomplishments in the light of the two major technical objectives of the program: these objectives being first to uncover the development problems by analysis and test and to take corrective action. The second is to provide the technical management necessary to maintain a balance between development items competing for available funds:

The problems encountered, the progress made toward their solution during the year and the status at the end of the year are summarized as follows:

SUB-TASK 1.1

A. In sub-task 1.1 the constraints imposed by the facility and NES system were recognized and the engine system was redesigned to dump the turbine exhaust gases into the nozzle exhaust at the exit plane.

B. The RIFT contractor proposed a different mechanical interface and a different TVC system from that of the NERVA engine. AGC analyzed their proposed method and made a presentation to NVPO and MSFC. The problems inferred by their proposal are far reaching - they could lead to a major redesign of the thrust structures, the pneumatic gas supply system, and possibly the test stand interface and support equipment redesigns. This is an open item at year's end but informal feedback indicates an acceptance by NVPO and MSFC of the NERVA mechanical interface and TVC system.

C. The need for various interface gages and match plates were reanalyzed, the requirements reduced by a plan that still yielded the same information.

D. Fabrication difficulties were encountered on the pressure vessel to reactor interface gage; they were overcome and the gage delivered on a schedule compatible with the NRX requirements. 
E. While there were no specific problems in the systems analysis area, the many analyses being made were not coordinated to the most effective degree. In response to the customer's guide lines the efforts were centralized and, within Aerojet, brought into focus by reorganization.

SUB-TASK 1.2

A. At the beginning of the contract year the major problem of developing hydrogen cooled bearings for the TPA was still with us, and during the contract year we demonstrated the work statement requirement for one hour's endurance test in a non-radiation environment. Although the 5 minute demonstration in a radiation environment was not performed during the contract year, the test pallet was delivered and during the month of October this demonstration was made.

B. At the beginning of the contract year we were faced with the problem of a redesign of the TPA to take care of the increased head requirements brought about by the various increases in system pressure drop resulting from increased reactor core $\triangle P$, increased nozzle $\triangle P$ and the normal increases one encounters and allows for. Normally, this problem would be handled by slight increases in pump speed; however, we were faced with the problem of handing a significant horsepower increase and we had a lid of critical speed imposed on us. The redesign was accomplished by eliminating one of these turbine stages. This resulted in an increase of the critical speed from 28-29,000 to 35-36,000 rpm, and allowed the design speed to be increased from approximately 20,000 rpm to 24,000 rpm.

C. The redesign above resulted in a decreased efficiency of the turbine and so the Mk IV was designed. The Mk IV incorporated the additional desirable features of the thrust balance piston and provisions for shaft seals so that a wet pump start may be utilized, if, for instance, the RIFT contractor proposal to move our tank shut-off valve downstream becomes an actuality.

SUB-TASK 1.4

A. The nozzle fabrication problem with the cast aluminum jacket was with us early in CY 1963. The first problem of separation of the casting from the tube bundle was corrected by providing interlocks; the second problem of brittle failure 
of the first Kiri nozzle resulted in a rapid acceleration of effort and has yielded an increase in "as-cast" properties from $1 \%$ or less to a minimum of $6 \%$ elongation (the design requirement). We have qualified two new foundries on this important problem and although we have not fully demonstrated the structural integrity of the design, there is every indication that the casting techniques will yield the required material properties. The problems we carry into contract Year 1964, namely, the problem of obtaining reproducibility and the in-process handling problems are different than the one we encountered on the Kiwi nozzle failure.

SUB-TASK 1.5

The problem encountered with the turbine power control valve actuator has been described in some detail; that we have obtained a solution to these is evidenced by the satisfactory operation in a radiation environment. Detail analyses have uncovered potential problems associated with the integration of the actuator with the turbine power control valve. Corrective redesign was accomplished. The problem carried over into contract Year 1964 is one of maintaining close tolerances. However, this problem was handled during CY 1963 by using lapping techniques which are generally accepted good practice in the early stages of development.

SUB-TASK 1.9

At the beginning of the contract year, it was recognized that the major problem involved in this area was primarily one of proper organization and management of this rather complex task. That corrective action has been taken at Aerojet may not have been apparent at the end of the contract year, but the fact that three of the five pallet tests carried over to Contract Year 1964 were completed in October of this year.

The Dewar failures encountered on the materials irradiation program has been corrected by redesigns which have been submitted to SNFC-C for approval. 
TASK 2.4

Going into this contract year the major technical problem was one of measuring accurately the liquid hydrogen temperature in support of the TPA development program and the development of a reactor outlet temperature sensor for control purposes. One of these problems, namely the liquid hydrogen temperature sensor, was solved and although the other remains with us, the problem was defined and a development plan has been established for proceeding. At this time the sensor utilized by IASL is considered adequate for the NRX-reactor tests even though the ultimate life, response rates, and accuracy for engine operation are not met.

TASK 3.1

At the beginning of the contract year, we were confronted with a situation of having solved the technical problems of producing a design that would adequately handle the heat transfer problem, the safety, and the operational problem but the funding constraints and facility limitations (which could have been solved by additional funding for modifications) required a more economical solution. This imposed a new series of technical problems. In cooperation with the technical staff of SNPO-C and Lewis, solutions to these problems were made and on schedule. It should be noted that AGC recognized the magnitude of the problems and took the necessary steps to cope with them by establishing a separate project organization.

\section{NRDS FACILITY SUPPORT TASKS}

As you have seen, these tasks present a variety of problems, but the major one is the sporadic nature of the work load due to the unscheduled receipt by Aerojet of various sets of drawings and specifications for review. The work has in general been accomplished in a timely manner. However, we do recognize that all of the customer requested review completion dates were not met. We consider this a problem that needs the joint concerted action of SNPO-C and AGC. Anything that can be done to schedule the work load of A-E design reviews at a steady level will be directly applicable to the alleviation of this problem. 
I would now like to summarize the milestone accomplishments for Contract Year 1962. (Use chart). I wish to point out that my analysis is based on the milestone report, exclusive of Task 4, included in the monthly report for September and, due to a few corrections to that report, is slightly in error and will be corrected at the same time we respond to the questions raised in this review. Of the 75 milestones carried over into Contract Year 1963, 22 are associated with the NRX program; of the 22 AGC is dependent upon the nuclear subcontractor for inputs for accomplishing 10 of them. None of the AGC items were, at the end of CY 1963, pacing the NRX program. Five are associated with the CFDTS and because of the reschedule of this system, are not pacing. An additional seven milestones are associated with the delays in placing the subcontract with GE for the explosive irradiation experiments.

There are 24 associated with the Task 5 and 6 series and of the remaining, 15 are associated to the component development subtasks and 2 are solely dependent on the nuclear subcontractor's efforts. 


\section{CY I963 MILESTONE SUMMARY}

\begin{tabular}{|c|c|c|c|c|c|}
\hline$S / T$ & $\begin{array}{c}\text { TOTAL } \\
\text { NUMBER }\end{array}$ & $\begin{array}{c}\text { NUMBER } \\
\text { CANCELLEED }\end{array}$ & $\begin{array}{c}\text { NUMBER } \\
\text { REMAINING }\end{array}$ & $\begin{array}{c}\text { NUMBER } \\
\text { COMPLETED }\end{array}$ & $\begin{array}{c}\text { NUMBER } \\
\text { CARRIED OVER }\end{array}$ \\
\hline $\begin{array}{l}1.1 \\
1.2 \\
1.4 \\
1.5 \\
1.6 \\
1.7 \\
1.9 \\
2.1 \\
2.2 \\
2.3 \\
2.4 \\
2.6 \\
2.7 \\
2.8 \\
3.1 \\
3.8 \\
5.1 \\
5.2 \\
5.3 \\
5.4 \\
5.5 \\
5.9 \\
6.2\end{array}$ & $\begin{array}{r}43 \\
20 \\
20 \\
18 \\
30 \\
6 \\
3 \\
15 \\
9 \\
12 \\
31 \\
9 \\
31 \\
14 \\
13 \\
1 \\
14 \\
8 \\
26 \\
7 \\
5 \\
5 \\
3\end{array}$ & $\begin{array}{l}6 \\
0 \\
0 \\
1 \\
0 \\
0 \\
0 \\
0 \\
0 \\
0 \\
7 \\
2 \\
0 \\
0 \\
0 \\
0 \\
1 \\
0 \\
1 \\
0 \\
0 \\
0 \\
0\end{array}$ & $\begin{array}{r}37 \\
20 \\
20 \\
17 \\
30 \\
6 \\
3 \\
15 \\
9 \\
12 \\
24 \\
7 \\
31 \\
14 \\
13 \\
1 \\
13 \\
8 \\
25 \\
7 \\
5 \\
5 \\
3\end{array}$ & $\begin{array}{l}25 \\
11 \\
17 \\
12 \\
19 \\
4 \\
3 \\
14 \\
8 \\
11 \\
22 \\
7 \\
26 \\
12 \\
13 \\
1 \\
9 \\
5 \\
13 \\
5 \\
4 \\
4 \\
2\end{array}$ & $\begin{array}{c}12 \\
9 \\
3 \\
2 \\
11 \\
2 \\
0 \\
1 \\
1 \\
1 \\
2 \\
0 \\
5 \\
2 \\
0 \\
0 \\
4 \\
3 \\
12 \\
2 \\
1 \\
1 \\
1\end{array}$ \\
\hline TOTALS & $\overline{343}$ & 18 & 325 & 247 & 75 \\
\hline
\end{tabular}




\section{SUMMARY}

We would now like to review the cost aspects of the CY 63 effort. These handout charts are provided for your reference during the discussion.

The first chart is provided as an overall SNP-1 summary. MOD 5 was in existence at the end of CY 62 with a total authorized committed cost of about 33.4 million. When MOD 6 was established, the total obligated authority increased by 57.9 million. However, several tasks, namely $1.1,1.6,1.9,2.6$ and 3.I were partially funded pending further negotiation. Subsequently, MOD 8 was negotiated which, in removing the partial funding, also incorporated the revision to the hot bleed cycle rather than heated bleed. This increased obligational authority an additional 13.3 million.

The recent addition of change order 1 , resulting in changes in subtasks 1.1, 1.3, 1.4, 1.6, 2.1, 2.2, 2.4, 3.1, 3.3, and 5.0, increased the obligational authority by approximately 1.7 million. This change order is not yet finally negotiated: however, the total obligational authority is undoubtedly very close to the $\$ 106,318,324$ noted on the chart.

It can be seen that, as of 30 september, we are under committed by 2.163 million and under expended by 4.135 million, but that open commitments are about 2 million more than originally estimated, thus indicating heavy procurement activity.

This total contract status has then been broken down to a CY 63 status by major participants. As can be seen, the under commitment is approximately evenly divided amoung AGC, WANI and AMF at about the $\$ 700,000$ level. However, the under expenditure is $2.9, .7$ and .4 million, respectively, with Bendix $\$ 39,000$ under expended. More will be said later about the under committed variances.

Another way of describing the total CY 63 status is shown at the bottom of the chart to reference the amount of new funding for CY 63 as opposed to the unused portion of CY 62 funds that existed at the beginning of CY 63 . It can be seen that the under commitment and under expenditure are both less than at the same time last year. 
As noted on the chart, all costs include subcontractor G \& A and fee, AGC $G \& A$, but no AGC fee.

The next chart provides a summary of the cost elements involved in the previous information. Direct lab $r$ has been very close to budget with direct labor overhead withun 3\% of that forecase for the year. Material and outside production is $12 \%$ under estimate as would be expected from the general undercommitted status although there has been some exchange of inside labor for outside services. Ttotal administrative expense has been very close to that forecast, although the $G$ \& $A$ rate has been somewhat higher than estimated. This would have caused total $G$ \& A expense to have been slightly higher had the subcontractor and outside procurement costs been fully realized.

The next series of charts entitled CY 63 NERVA Costs, wre provided to reduce the previous information to the subtask level. To avoid possible confusion these charts are all prepared on a commltted basis since we feel that is, in general, a more accurate approach to the measurement of progress than are expenditures. On these charts all subcontracting or outside procurement is included except that effort being performed by Westinghouse. This is done since you are primarily concerned with AGC at this briefing and since you had a review of Westinghouse last week.

The column entitled RN-02012 is the prugram plan number which resulted in Report 2322, and the costs are the same as in 2322.

In preparing these charts, recognition was given to the fact that you have already been given considerable detail during the subtask reviews. Therefore, the objective of these charts is to indicate the impact of the various contract changes from a cost standpoint and to summarize the major causes for variations from planned subtask costs.

The first of these charts reviews Task 1 .

Subtask 1.1 - Engine System costs were $\$ 544,000$ under budget. As the year progressed, certain programmed effort became unnecessary or unrealistic. The NRX program slippages made it impossible to accomplish NRX hardware cold flow acceptance testing at LRP. The CFDTS relied on the use of NRX hardware which would become available following the NRXA-I cold flow test. This inderdependency 
made it logical to reschedule the CFDTS which permitted a savings in CY 63 . It became possible to use actual hardware, rather than special mockup hardware. Economies were achieved in fabrication and test administration costs. All these combined to effect a considerable saving in the CY 63 period and allowed this money to be re-allocated to other subtasks where problems were being encountered. Subtask 1.2 - The propellant feed system effort exceeded that planned by $\$ 701,000$. Development problems in the turbo pump and bearing areas were encountered. In addition, several design changes were requested by SNPO-C during: the year. Most significant of the latter was the decision to create the MOD 2 version of the MARK IV TPA to incorporate a balance piston and to provide a capability to operate as a "wet" pump without an upstream tank shut off valve. This decision resulted in substantial redesign and an extended schedule for completion of the MARK IV design. In addition, a number of added scope items, previously mentioned, added substantially to the total effort required.

Subtask 1.3 - The reactor subassembly task effort exceeded the planned cost by only $\$ 64,000$. However, since this is nearly a $20 \%$ variance it deserves some recognition. This variance represents only $2-1 / 2$ man years effort and it was required to support the special NRX task force activities and the several program re-direction efforts.

Subtask 1.4 - Cost associated with the thrust chamber assembly exceeded that first planned by $\$ 564,000$. When difficulties were encountered in casting satisfactory aluminum jackets, a special task force was formed and alternate foundries were brought into the program. In addition, because of this problem and the critical effect on the NRX program, it was decided to rework two NRX nozzles to incurporate camera and light ports rather than only one. Further, poor quality pressure vessel forgings caused added fabrication and inspection effort.

Subtask 1.5 - The cost of the engine control task was less than planned by $\$ 91,000$. This was caused by the delay in availability of subcontracted hardware which delayed evaluation and analysis of the test operators console. An additional item not noted on the chart is a late procurement of an alternate source TPCV actuator. 
Subtask 1.6 - The destruct system task was under committed by $\$ 154,000$. This resulted from a delay in resclving arrangements with the government which were required prior to proceeding with completion of the Garfield Flats Facility for explosive testing. In adaition, a procurement delay was encountered with the subcontractor who will perform irradiation testing of explosives.

Subtask 1.7 - The $\$+3,000$ cost variance in the pneumatic supply system task was caused by the need for additional liaison with the RIFT contractor with corresponding analysis and a sinall under estimate of fabrication costs.

Subtask 1.8 - NRDS operations cost was significantly below that first planned $(\$ 513,000)$. This is entirely due to the delay in reactor testing which permitted a reduced level of staffing.

Subtask 1.9 - The cost of the radiation effects task was $\$ 73,000$ below budget. This resulted from the fact that delays were encountered in fabricating the mechanical and electrical radiation effects pallets. There was an exchange of funds planned for testing to permit repair of equipment at convair, Fort Worth, but this was approximately an even trade-off.

Incidentally, before going to the next chart covering task 2, it may be appropriate to note that some of the delays just mentioned result in CY 63 work being carried over into CY 64. Mr. Ryland will cover this subject when I am through.

Subtask 2.I - The under commitment,s of $\$ 601,000$ is remote handing equipment is the direct result of delays in procurement by the subcontractor. Subtask 2.2 - The ground support equipment (checkout and test) task was accomplished $\$ 19,000$ below budget which is considered well within estimating tolerance.

Subtask 2.3 - The ground support equipment (handing and maintenance) task required $\$ 206,000$ more than first planned. Technical problems were encountered which necessitated considerable redesign and the fabrication costs of transporting and handing equipment for the pressure vessel were under extimated.

Subtask 2.4 - The cost to perform the diagnostic instrumentation task exceeded the estimate by $\$ 220,000$. This $14 \%$ variance resulted from changes in 
the measurement lists for the NRX-AI and $\mathrm{A} 2$ instrumentation and a greater-thananticipated effort on the instrumentation data book.

Subtask 2.6 - The reliability and quality assurance task required $\$ 119,000$ or $11 \%$ less than estimated. Later-than-estimated implementation of the more comprehensive reliability and quality control program plans was the cause.

Subtask 2.1 - The safety program was performed for $\$ 123,000$ less than first estimated. Due to schedular considerations, the flight operational safety systems requirements report was deferred, thus permitting a lower level of effort.

Subtask 2.8 - A savings of $\$ 21,000$ was possible in the training program as a result of the rate of build up of staff at NRDS.

Subtask 2.9 - This IASL support task is a level of effort with support as requested. The requested level permitted an under expenditure of $\$ 39,000$.

The next chart presents the task 3 effort.

Subtask 3.0 - While this general support facilities task is under the estimate by $\$ 13,000$, it is desired to point out that a significant unplanned study effort was conducted this year at the request of SNPO-C to evaluate the possibility of using ETS-I facilities or an alternate upwará firing stand for reactor tests.

Subtask 3.1 - The NERVA exhaust system test was accomplished within $\$ 59,000$ of budget. This small variance was caused by late arrival of a GFE van which delayed the I \& C installation in the test area where scale model testing is conducted.

Subtasks 3.2 through 3.9 - are basically level of effort activities and with two exceptions were all accomplished at less than first estimated. Subtask 3.3 required $\$ 37,000$ more than estimated because review of drawings and coordination with the ETS-I I \& C contractor exceeded the estimated scope. Subtask 3.6 reactor development facility required $\$ 22,000$ or approximately one man year more than estimated. This subtask provides field engineering support for test cell $A$ activities and procedures, and was accomplished without permanent transfer of personnel to Nevada.

In all, a significantly lower cost $(\$ 294,000)$ was realized while accomplishing task 3 . 
The next chart relates to task 4.

All of task 4 subtasks except subtask 4.3 were performed at less than budgeted levels despite their sensitivity to the numerous reprogramming efforts. The cost of these tasks is predominantly labor which indicates that desired staffing was not achieved. As in all uther tasks, the required work was accomplished by use of excessive overtime, most of which was uncompensated. The cost, therefore, reflects a situation which we hope to correct in the future.

Subtask 4.5, Documentation, was over buaget by 440,000 . Here a major portion of the effort is accomplished by hourly personnel si that the extra work load is necessarily reilected in the increased cost.

The next chart reviews tasks 5 and 6 .

Subtask 5.1, STE - Test zone C, is under estimate by $\$ 123,000$. This occurred because certain work was delayed. Specifically this effort is associated with the nozzle adapter, diffusers, hot gas systems, associated instrumentation and the NRX-A cold flow installation equipment.

Subtask 5.2, STE - Cryo Lab, was within normal estimating tolerance on a cuntract year basis. However, delays were encountered which will reflect as costs after 1 Dctober.

Subtask 5.3, STH - Test zone H, was performed for $\$ 276,000$ below budget. This reduction resulted from incompletion of the nozzle adapter, coulant system, hot gas system, ejectors and miscellaneous propellant system test installations which were incomplete.

Subtask 5.4, STE - Azusa, was performed for $\$ 16,000$ or $16 \%$ below the estimate. This STE involves modification and updating of the PACE analog. All equipment planned for CY 63 was procured.

Subtask 5.5, STE Downey, was performed for $\$ 10,000$ less than estimated but sould have been on budget had not the procurement of telemetry equipment and a theodolite been delayed.

Subtask 5.7, STE - Test zone G, was completed for $\$ 11,000$ above estimate. While this is a large percentage, the small dollar value does not seem significant. 
Subtask 5.8, was associated with the temperature lab at LRP. During the year it was deemed more proper to transfer effort associated with a calibration cryostat to subtask 5.9. The residual costs for subtask 5.8 are therefore $\$ 55,000$ below budget.

Subtask 5.9, STE - LRP laboratory bldg., was under budget $\$ 36,000$ including the effect of the transfer from subtask 5.8. However, this under budget condition results from incompletion of $\mathrm{LN}_{2}$ piping and the calibration cryostat.

Subtask 6.1, other government property - test zone H, was completed substantially below estimate $(\$ 31,000)$.

Subtask 6.2, other government property - test zone A, was $11.5 \%$

$(\$ 26,000)$ below estimate. This was a result of incompletion of a $\mathrm{LN}_{2}$ piping system because of subcontractor difficulties.

Subtask 6.4, other government property - development fabrication facility, was withdrawn from the program before MOD 8 was finalized and was shown only as reference to complete the MOD 6 summary. 


\section{SNP-I COST SUMMARY}

SNP-I COST SUMMARY

\begin{tabular}{|c|c|c|c|c|c|c|}
\hline & \multicolumn{3}{|c|}{ EXPENDED CONTRACT AMOUNT } & \multicolumn{2}{|c|}{ ACTUAL COSTS } & COMMITTED \\
\hline$T$ & 2 & 3 & 4 & 5 & 6 & 7 \\
\hline MOD 5 & $32,454,115$ & 940,683 & $33,394,798$ & $27,844,826$ & $2,960,919$ & $30,805,745$ \\
\hline MOD 6 & $89,199,848$ & $2,095,511$ & $91,295,359$ & & & \\
\hline MOD 8 & $99,524,975$ & $5,057,303$ & $104,582,278$ & & & \\
\hline C/O NO.I & $100,097,498$ & $6,220,826$ & $106,318,324$ & $95,962,269$ & $8,193,168$ & $104,155,437$ \\
\hline
\end{tabular}

\begin{tabular}{|c|c|c|c|c|c|c|}
\hline & \multicolumn{3}{|c|}{ EXPENDED } & \multicolumn{3}{|c|}{ COMMITTED } \\
\hline & BUDGET & ACTUAL & VARIANCE & BUDGET & ACTUAL & VARIANCE \\
\hline $\begin{array}{c}1 \\
A G C\end{array}$ & $\begin{array}{c}2 \\
34030.523\end{array}$ & $\begin{array}{r}3 \\
31085\end{array}$ & $(2054.938)$ & $\begin{array}{c}5 \\
33.672 .514\end{array}$ & $\begin{array}{c}6 \\
32002465\end{array}$ & $7^{7}$ os/9) \\
\hline WANL & $33,957,139$ & $33,233,0$ & ( $724,6 t)$ & $36,800,842$ & $36,078,1$ & $(722,798)$ \\
\hline AMF & $2,739,627$ & $2,321,598$ & $4(8,029)$ & $3,562,710$ & $2,895,973$ & $(666,737)$ \\
\hline BENDIX & $1,516,383$ & $1,477,2$ & $39,0 \mathrm{~d})$ & $1,476,513$ & $1,473,150$ & $3,363)$ \\
\hline TOTAL & $72,252,672$ & $68,117,443$ & $(4,135,229)$ & $75,512,579$ & $73,349,692$ & $(2,162,887)$ \\
\hline
\end{tabular}

CV 63 STATUS

\begin{tabular}{|c|c|c|}
\hline & EXPENDED & COMMITTED \\
\hline NEW FUNDING CY63 & 2 & 3 \\
UNEXPENDED CY 62 & $67,643,383$ & $72,923,526$ \\
TOTAL FUNDING CY 63 & $72,609,289$ & $2,589,053$ \\
ACTUAL CY63 & $68,117,443$ & $75,512,579$ \\
UNEXPENDED CY63 & $4,135,229$ & $2,162,887$ \\
\hline
\end{tabular}

NOTE: ALL COSTS INCLUDE $S / C G \& A$ AND FEE AND AGC $G \notin A$. ALL ACTUALS AS OF $9 / 30 / 63$ $10 / 30 / 63$ 
CY 1963 COST ELEMENT SUMMARY

COMMITTEDD

THOUSANDS

\begin{tabular}{|c|c|c|c|}
\hline & BUDGET & ACTUAL & VARIANCE \\
\hline DIRECT LABOR (AGC) & 9,752 & 9,942 & 190 \\
\hline DIRECT LABOR OVERHEAD (AGC) & 10,322 & 10,681 & 359 \\
\hline MTLS \& O.P. (AGC) & 11,427 & 10,005 & $(1,422)$ \\
\hline SUBCONTRACTORS & 41,841 & 40,447 & $(1,394)$ \\
\hline$G \& A(A G C)$ & 2,170 & 2,274 & 104 \\
\hline TOTAL & 75,512 & 73,349 & $(2,163)$ \\
\hline
\end{tabular}


NTRACT YEAR 1963 NERVA COSTS

WANL EXCLLDED

(COMTCITH - W/ACC GRA)

Thousends

\begin{tabular}{cccccccc} 
Subtask & $\begin{array}{c}\text { RNV-62012 } \\
\text { Mod 6 } 6\end{array}$ & $\begin{array}{c}\text { RNI-63002 } \\
\text { Mod } 8\end{array}$ & $\begin{array}{c}\text { RN-63013 } \\
\text { C/0 \#1 }\end{array}$ & Total & $\begin{array}{c}\text { CY 1963 } \\
\text { Actual }\end{array}$ & Variance & REMARKS \\
\hline 1 & 2 & 3 & 4 & 5 & 6 & 7 & 8 \\
\hline
\end{tabular}

\begin{tabular}{|c|c|c|c|c|c|c|}
\hline 1.1 & 971 & 2,991 & 33 & 3,024 & 2,480 & $(544)$ \\
\hline 1.2 & 3,286 & 3,730 & -- & 3,730 & 4,431 & 701 \\
\hline 1.3 & 477 & 342 & - - & 342 & 406 & 64 \\
\hline 1.4 & 4,565 & 5,233 & 119 & 5,352 & 5,916 & 564 \\
\hline 1.5 & 2,179 & 2,013 & - & 2,013 & 1,922 & (91) \\
\hline 1.6 & 1,440 & 1,704 & - & 1,704 & 1,550 & $(154)$ \\
\hline 1.7 & 365 & 239 & -- & 239 & 282 & 43 \\
\hline 1.8 & - & 869 & $\cdots$ & 869 & 356 & (513) \\
\hline 1.9 & 845 & 2,443 & -- & 2445 & 2,335 & $\begin{array}{l}(108) \\
+795\end{array}$ \\
\hline Total & 14,122 & 19,564 & 152 & 19, & 19,678 & \\
\hline
\end{tabular}

Effort reduced due CFDTS and NRX acceptance test rescheduling. Used actual hardware rather than special mock ups. Achleved economies in fabrication and test administration.

Effort increased to solve development problems and to incorporate requested changes to Mark IV, Mod 2 TPA. Added scope 1 tems.

Increased effort for reactor task force support and program re-direction effort.

Increased effort to resolve aluminum jacket casting problems and expedite fabrication through task force approach. Addition of windows in two nozzles.

Late recelpt of subcontractor hardware delayed evaluation tests and analysis of test operator's console.

Procurement delay for explosive 1rradiation test and Garfield Flats facility.

Additional RIFT liaison and underestimated fabrication cost.

Delay in reactor program permitted reduced stafeing level.

Delay in manical and electrical radiation effects pallets. 


\begin{tabular}{|c|c|c|c|c|c|c|c|}
\hline Subtask & \multicolumn{7}{|c|}{$\frac{\text { CONTRACT YEAR } 1963 \text { NERVA COSTS }}{\text { WANL EXCLUDED }}$} \\
\hline 1 & 2 & 3 & 4 & 5 & 6 & 7 & 8 \\
\hline 2.1 & 4,221 & 3,692 & 25 & $3, \pi 7$ & 3,107 & $(610)$ & Subcontractors procurement of remote handling equipment delayed. \\
\hline 2.2 & 932 & 415 & 30 & 445 & 426 & (19) & Within estimated tolerence. \\
\hline 2.3 & 735 & 610 & -- & 610 & 816 & 206 & $\begin{array}{l}\text { Underestimated fabrication cost for transporting and handling equipment for } \\
\text { pressure vessel. }\end{array}$ \\
\hline 2.4 & 965 & 1,552 & 15 & 1,567 & 1,787 & 220 & 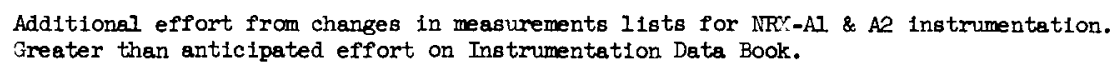 \\
\hline 2.5 & 35 & -- & -- & -- & $\cdots$ & -- & \\
\hline 2.6 & 398 & 1,088 & $\cdots$ & 1,088 & 969 & (119) & $\begin{array}{l}\text { Effort delayed due to later implementation of reliability and quality control } \\
\text { program plans. }\end{array}$ \\
\hline 2.7 & 235 & 302 & -- & 302 & 179 & (123) & $\begin{array}{l}\text { Flight operational safety systems requirements report deferred. Iower level of } \\
\text { effort applied. }\end{array}$ \\
\hline 2.8 & 214 & 124 & $\cdots$ & 124 & 103 & (21) & Task completed at reduced cost as result of slow NRDS build up. \\
\hline 2.9 & 469 & 242 & -- & 242 & 203 & (39) & Support furnished as required. \\
\hline Sub-Total & 8,104 & 8,025 & 70 & 8,095 & 7,590 & $(505)$ & \\
\hline
\end{tabular}




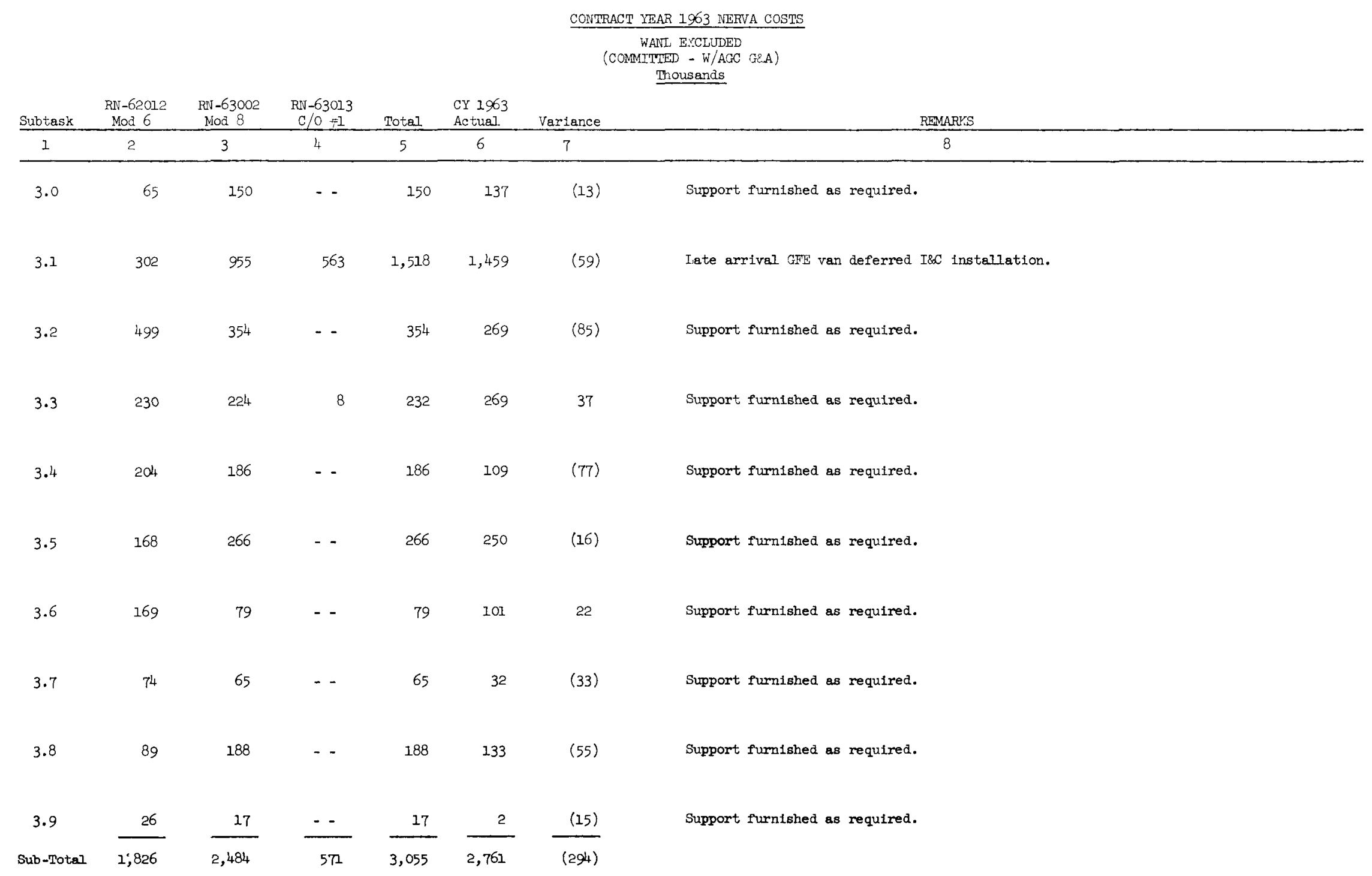




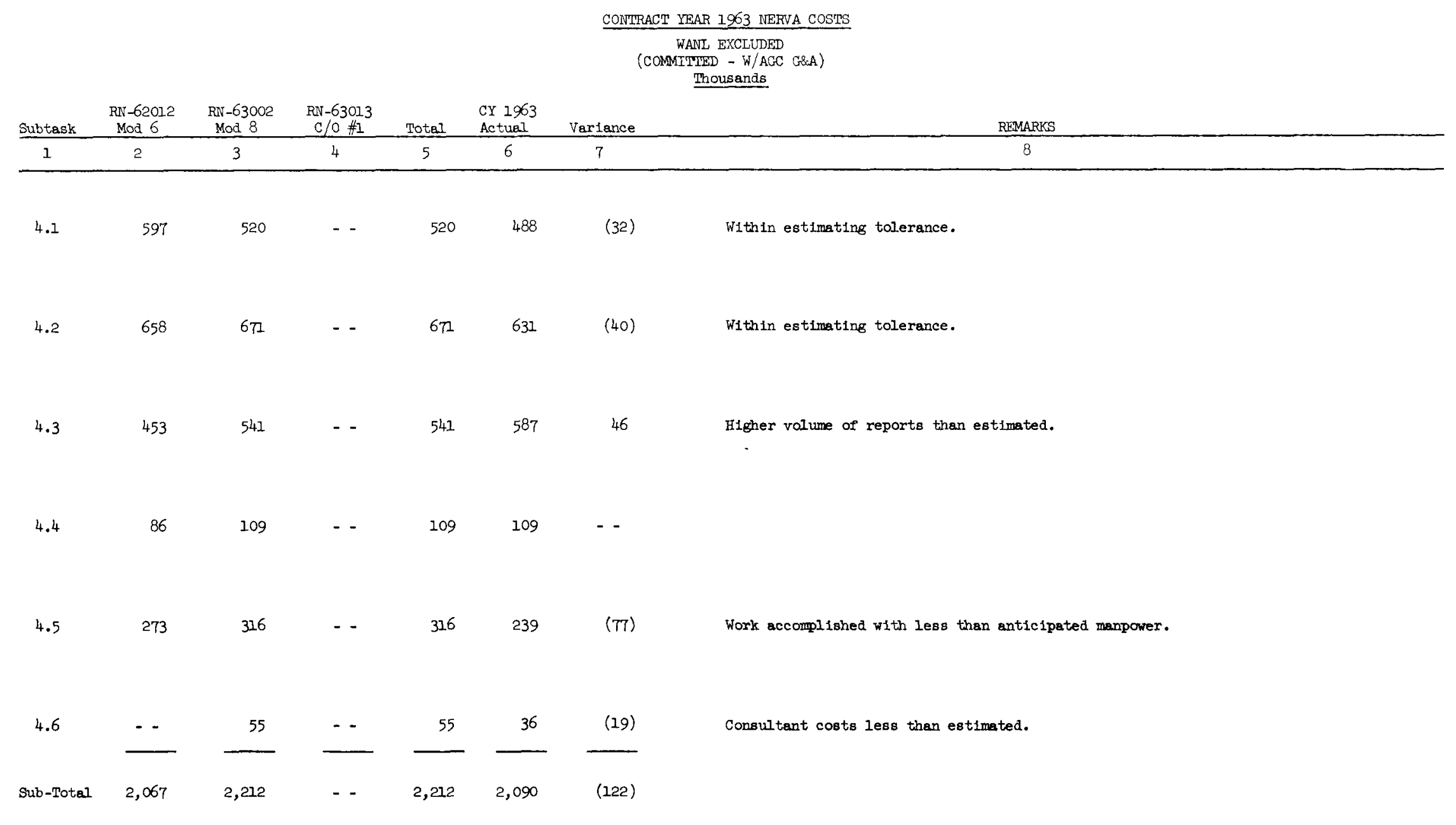




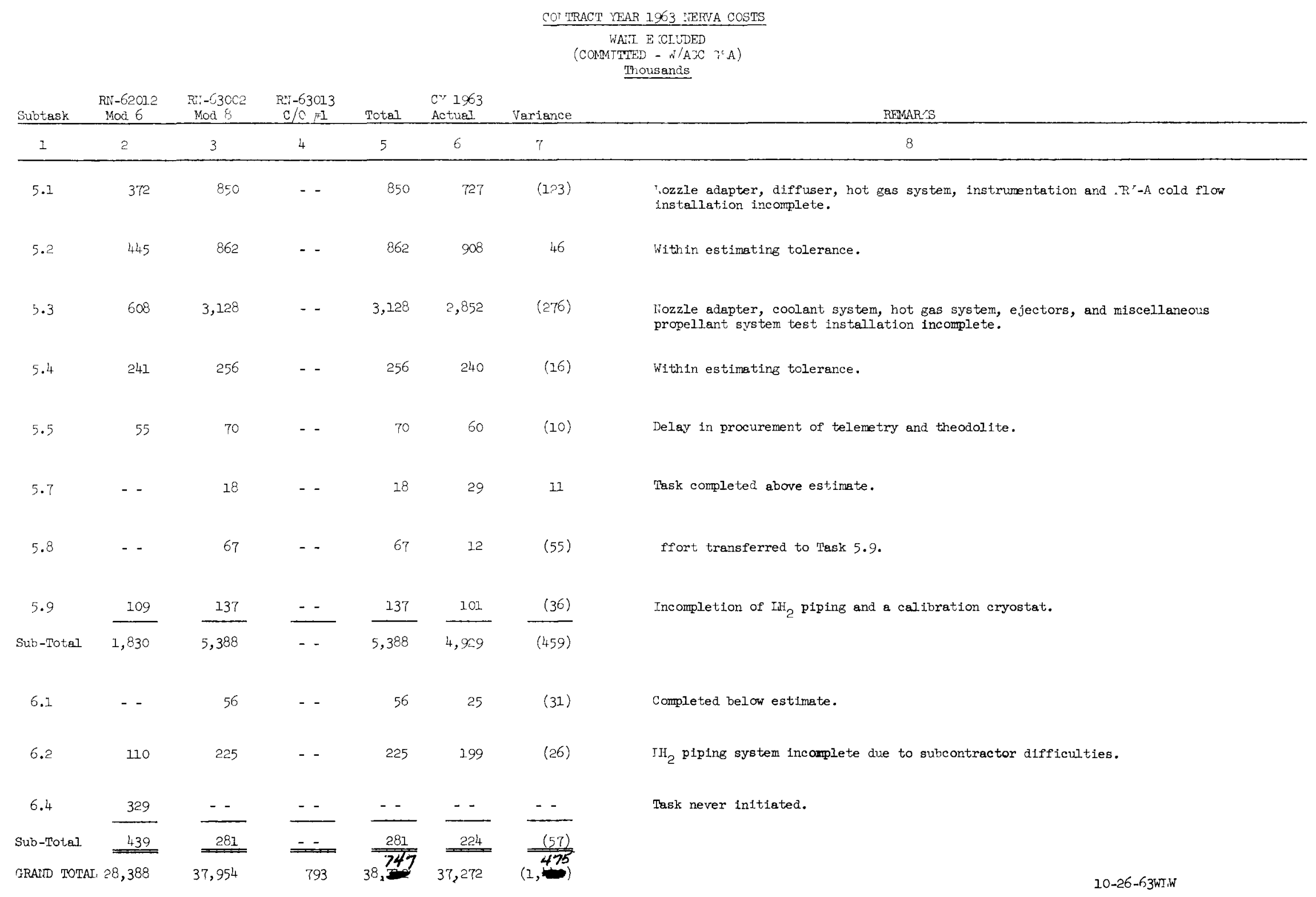




\section{E. ESTIMATE TO COMPLETE CY 1963 WORK}

On August 21 Aerojet-General Corporation made a presentation in Cleveland to describe the estimates to complete CY 1963 work which would not be finished at September 30. The premises were established as of July in order to create a start point for the 1964 Contract Year proposal. Assumptions were made regarding items which appeared to be close to completion at 30 September and, in general, these were estimated to be complete and the dollar amounts attributable to them were estimated to be committed. A number of these areas were not completed exactly as contemplated and have slid over the line resulting, as you have seen by Mr. Wheeler's discussion, in a lower than predicted commitment and expenditure at 30 september and a commensurate increase in the estimate to complete.

Aerojet in re-estimating its position as of the end of the Contract Year has been as objective as possible in establishing dollar amounts remaining to be committed against CY 1963 work. As you recognize, the contractor is bound only by the contractual language and not by numerous subsidiary written or oral representations which are not in the nature of contractual commitments. Nevertheless, in reviewing the status of the program we have recognized some gray areas wherein the contractual work statement: was subject to interpretation and I wish to assure you that we have not always made our judgement solely one way. We recognize our presentation today is not in the nature of a negotiation, but is an effort to provide some bases for the Government's evaluation of the contractor's performance and completion status. The cost status and dollar estimate of work to be completed are only a part of this. Any differences on the dollar estimates to complete will, of course, be subsequently ironed out in the CY 1964 negotiations.

You have been given detailed technical presentations on each of the program areas. In addition, you have been handed "backup packages" which include milestone accomplishments, as well as deferrals past September 30. In the technical presentation charts the completion - non-completion status is correlated to the contract work statement requirements. It is not my intention to be redundant with that which you already have but to summarize, in 
terms of dollars, the contract work for 1953 which remains to be accomplished after september 30 .

The tabulation of our estimated cost to complete has been handed out to you. Let's take a look at the individual subtasks wherein we believe completion effort is indicated. As was stated previously in the cost status presentation, the figures shown exclude WANL carryover costs which are treated separately.

Subtask 1.1 - Engine System

The basic objectives of this integration task were met. There were some items affected, however, by the reactor test program schedule, and acceptance testing of NRX-A non-nuclear hardware will be completed in Contract Year 1964. Also remaining to be completed is the fabrication of certain CFDTS unique hardware. By Change Order 1 to Mod 8, nuclear rocket mission study work was initiated late in the contract year and this will be furnished in November. Together, these unfinished efforts total $\$ 144,000$.

Subtask 1.2 - Propellant Feed System

The major development effort on the propellant feed system was complete, but some early problems, numerous program changes plus unavailability of test facilities at the required time resulted in some hardware and test effort being carried over to CY 1964. These efforts include performance of a 10-min TPA endurance test, completion of thrust balance tester and testing, as well as radiation testing of liquid hydrogen cooled bearings (completed in October 1963) and completion of CFDTS feed lines. The unfinished portion of work is estimated at $\$ 133,000$.

Subtask 1.3 - Reactor Subsystem Management

This work was primarily level of effort and no carry-over is

involved.

\section{Subtask 1.4 - Thrust Chamber Assembly}

The development problems related to fabrication of the nozzle resulted in hardware fabrication and test activities being performed after september 1963. The primary items remaining to be accomplished are fabrication and test 
of NRX-A reactor nozzles and inlet lines, skirts, thrust structures and nozzles for development testing. The sum of remaining CY 1963 work is $\dot{\psi} 501,000$.

\section{Subtask 1.5 - Engine Controls}

Essentially all work was completed with the exception of conduct of evaluation testing and analysis of test operators console design effort on remote engine control system and subcontracted TPCV actuator effort. This latter was committed in October. The total deferred cost is $\$ 175,000$.

Subtask 1.6 - Destruct System

All development work was completed with the exception of radiation effects on explosives which is being covered in Subtask 1.9. The facilitization of the Garfield Flats Test area in Nevada was not as complete as planned due to a combination of procurement and approval problems. A total of $\$ 131,000$ associated with this facility expansion will be done in Contract Year 1964.

Subtask 1.7 - Pneumatic System

All work was completed.

Subtask 1.8 - NRDS Operations

Since this was essentially a level of effort task to support testing at NRDS it is considered complete.

Subtask 1.9 - Radiation Effects Program

Effort associated with the subcontracted radiation effects on explosives plus fabrication and checkout of electrical and mechanical pallets for radiation effects testing amount to $\$ 388,000$.

Subtask 2.1 - Remote Handiling Equipment

The later than anticipated completion of remote handling equipment fabrication by the subcontractor and the On Stand Hot Maintenance study results in effort approximating $\$ 667,000$ being done in Contract Year 1964 . 
Subtask 2.2 - Ground Support Equipment - Checkout and Test Systems

This task was complete except for two items of checkout equipment for the NRX-Al cold flow test - pressure vessel and nozzle closure kits which will be complete early in Contract Year 1964. About $\$ 5000$ are involved. Subtask 2.3 - Ground Support Equipment - Handling and Maintenance

This task has one area of incomplete fabrication and acceptance testing effort associated with NRX-AI handling equipment. This amounts to approximately $\$ 44,000$.

Subtask 2.4 - Instrumentation

This subtask called for a major instrumentation development program. The outstanding effort at the end of the contract year was to provide additional NRX-A instrumentation and to complete subcontracted development effort on radiation resistant microphones and tungsten resistance thermometers. This effort amounts to $\$ 357,000$ to be performed in Contract Year 1964 .

Subtask 2.6 - Reliability and Quality Assurance

There is no work deferred from Contract Year 1963.

Subtask $2.7-$ Safety

This level of effort task is considered complete.

Subtask 2.8 - Training

This effort was completed.

Subtask 2.9 - LASL Support

This work was complete.

Subtask 3.0 - General Support Facilities

Subtask 3.1 - NERVA Exhaust System

Subtask 3.2 - Test Stand ETS-1

Subtask 3.3 - ETS-1 Instrumentation and Controls

Subtask 3.4 - Test Stand ETS-2

$\mathrm{E}-4$ 
Subtask 3.5 - E-MAD Facility

Subtask 3.6 - Reactor Development Facility

Subtask 3.7 - Radiation Effects Facility

Subtask 3.8 - NRDS Radioactive Materials Handing, Decontamination and Storage Complex

Subtask 3.9 - RIF"T Stage Development Facilities

The entire Task 3 series are considered complete for Contract Year 1963.

Subtask 4.1 - Program Planning and Control

Subtask 4.2 - Fiscal Control

Subtask 4.3 - Additional Documentation

Subtask 4.4 - NERVA Central Data System

Subtask 4.5 - Subcontract Administration

Subtask 4.6 - Special Program Services

All of the Task 4 Series are considered complete with the exception of 4.3 which has open the completion of the year end technical report and film report. Approximately $\$ 38,000$ are involved.

Subtask 5.1 - LRP-Test Zone "C"

Completion of Test Zone activation requires work in CY 1964 on a number of items including nozzle adapter coolant system, hot gas system, ejectors and other propellant systems. An estimated $\$ 50,000$ will be committed subsequent to September 30 .

Subtask 5.2 - LRP Test Zone "A" - Cryogenics Laboratory

Approximately $\$ 70,000$ will be required to complete and install 4 bearing testers, environmental chamber $\mathrm{LH}_{2}$ piping and leak apparatus plus some instrumentation. 
Subtask 5.3 - LRP - Test Zone "T" Test Stands H-4, 5 and 6

As you know significant delay was incurred in activation of "H" area. A number of items were mentioned in the technical presentation which would be performed after September 30, 1963. Some of the more significant ones are completion of the nozzle adapter coolant system hot $\mathrm{H}_{2}$ system, ejectors, instrumentation and control. of $\mathrm{H}-4$ and $\mathrm{H}-6$. The estimated commitments to complete CY $196 \overline{5}$ work are $\$ 850,000$.

Subtask 5.4 - Special Test Equipment

Complete.

Subtask $5.5-$ Downey

Still open in support of destruct testing are procurement of some telemetry anà theodolite equipment. Amounting to $\$ 10,000$. Subtask 5.7 - Test Zone "G" - Test Stand G-7

Complete.

Subtask 5.9 - IRP Miscellaneous Non-Test Area Laboratories

To be completed is installation of $\mathrm{LN}_{2}$ piping and a calibration cryostat. Estimated $\$ 110,000$ remain to be committed.

Subtask 6.1 - Test Zone "H" Test Stands H-4, -5 and -6

Complete.

Subtask 6.2 - Test Zone "A" Engineering Cryogenics Laboratory

Procurement difficulty results in necessity to complete $\mathrm{LN}_{2}$ piping system installation for approximately $\$ 15,000$.

This brings us to the sum of estimated Aerojet work to be committed after september 30, 1963 amounting to $\$ 3,688,000$. This picture can be best shown by the Summary to Complete CY 1963 chart.

We have segregated Aerojet and WANI and present the actual September 30, 1963 cumulative commitments and expenditures against the contractual amounts authorized. The Aerojet costs shown can be checked out against our 
most recent detailed cost report submitted on 22 october. The estimate to complete figure in the committed column is recognized from the review we just presented. Adding provides the total required versus that presently authorized and the difference is the additional funding required to complete CY 1963 work. The expenditures column is likewise explained.

The figures shown in the WANL breakdown result from their latest cost report and the presentation at Pittsburgh 22 and 23 October. The WANL cost to complete figures result from the application of their fee and Aerojet $G$ \& A to the approximately $\$ 1.57$ million reported as "Estimated Cost to Complete" in their Chart No. 28.

Adding the Aerojet and WANL figures presents a total commitment cost to complete of $\$ 5.42$ million and an expenditure cost to complete of $\$ 7.39$ million requiring additional Contract SNP-1 funding of $\$ 3.258$ million.

As I am sure you recognize, from the technical program description the contractor has performed a large number of complex tasks, made more difficult by frequent programmatic revisions. Certain additional efforts nor originally contemplated were in fact done. The fact that $\$ 3.258$ million must be added to the contract should not be interpreted in a negative fashion. It is within reasonable estimating tolerance and it represents clearly that the contractor has approached a tough job without including normal cost contingencies one could consider and has maintained at the same time a necessary flexibility to meet various program changed requirements.

Again I point out, as I did in my opening remarks yesterday, Contract Year 1963 has been one of frequent reprogramming. The evaluation SNPO is making is in response to the experimental incentive fee clause of the contract. Aerojet has laid bare its unfinished work as well as its technical accomplishments and has attempted to be frank and objective throughout. Your evaluation affects an area about which industry and government are seldom completely objective. Yet we have given you the facts and ask that you weigh them carefully against the difficulty of the job, the year's environment, the context of a cost type $\mathrm{R} \& \mathrm{D}$ contract, and the probability of inventing on a precise schedule. 


\section{SNP-I SUMMARY TO COMPLETE CY'63}

(THOUSANDS)

\begin{tabular}{|c|c|c|c|c|c|c|}
\hline & \multicolumn{2}{|c|}{$A G C$} & \multicolumn{2}{|c|}{ WANL } & \multicolumn{2}{|c|}{ TOTAL } \\
\hline & COMMITTED & EXPENDED & COMMITTED & EXPENDED & COMMITTED & EXPENDED \\
\hline ACTUAL - 9/30/63 & 56,682 & 52,067 & 47,473 & 43,895 & 104,155 & 95,962 \\
\hline COST TO COMPLETE & 3,688 & 5,659 & 1,733 & 1,734 & 5,421 & 7,393 \\
\hline TOTAL REQUIRED & 60,370 & 57,726 & 49,206 & 45,629 & 109,576 & 103,355 \\
\hline TOTAL AUTHORIZED & 58,122 & 55,478 & 48,196 & 44,619 & 106,318 & 100,097 \\
\hline ADDITIONAL REQUIRED & 2,248 & 2,248 & 1,010 & 1,010 & 3,258 & 3,258 \\
\hline
\end{tabular}

NOTES: WANL FEE $₹$ AGC G\$A APPLIED

WANL COMMITTED ESTIMATE TO COMPLETE

ASSUMED $=$ EXPENDITURE 
Enclosure (3)

IEGEND: "Q" - Question/Comment by SNPO

"A" - Answer/Comment by AGC

\author{
CONTRACT SNP-I \\ CY 1963 STATUS PRESENTATION \\ 30-31 OCTOBER 1963 \\ QUESTIONS AND ANSWERS
}

$5.6+.2 .53 \times 1.1$

Q. When status is shown on the various charts, what is the "as of" date?

A. AII status charts reflect the completion status as of 30 september 1963 .

Q. Wher items are shown as deletions, does this mean by mutual agreement or were decisions unilateral?

A. Sowe items were by customer direction, some by mutual agreement, others were decisions of the contractor based upon achieving objectives in a more economical way. It is believed the customer was aware of any such decisions.

Subtack 1.2

Q. What was the specific design information with respect to TPCV actuators which was lacking?

A. This detailed information will be furnished. It is as follows:

Present fixed spline (female) on TPCV and fixed spline (male) on actuator could result in imposing radial load on actuator beainings. Bendix and IRP meeting held which resulted in solution to problem. It was decided to use malt "crown" splines on both the IPCV and actuator shafts with a female spline coupling to join the two male splines. This will require a change to the valve/actuator interface which will be accomplished in a CY 64 design change to the TPCV.

Q. Did the TICV actuator test get run?

A. Tt wras not planned to conduct tests with the Bendix actuator in CY 63 . Ioitiai TPCiv hot gas tests are to be run with an experimental actuator (nydrauiic). Following this test series the Bendix actuator would be used for testing. Hot gas tests have been delayed due to late activation of facility for hot gas testing in $\mathrm{C}-7$ area. 
Q. Regarding additional effort performed, what is the "increased Iiaison with SNPO-C Iocal representatives?"

A. The budget of this subtask was overrun. In analyzing the reasons for $i^{+}$, we assessed those things performed but not conterplated in the original estimates for CY 1963. One of these items was the extent to which time of our engineering personnel was deroted to communications and liaison with the technical representatives of SNPO-C at the Liquid Rocket Plant.

Sibtask 1.3

Q. Tre design review by Aerojet of $B 2 A$ and $B 4 D$ was requested by whom?

A. Mr. Rod Spence of IASI.

Q. How many mar hours were expended?

A. Goout zo0 man hours in each case.

Q Internal memoranda art listed in your charts as evidence of performance. Why aren't more memoranda in published reports and available to SNPO and WANL?

A. Tre content of such memos were used in meetings with WANL and as a general rule transmitted to WANL by letters.

Q. Effort on engine nozzle requirements really had to do with attitude control. Was this properly a Subtask 1.3 item?

A. Yrs.

Q. How dops work on flux determinations, etc. relate to WANL's work? How Is thle integrated? Are AGC maps different than WANL's?

A. The maps art ks, d on similar information. The AGC maps include information on non-nuclear hardware. Tre first map had minor amount of differtage as between WANL and AGC.

Q. How about codes?

A. Cades are related to the operat ional engine aspects, not the flux map.

Q. Are you $u=$ ing the same code information?

A. If mary cases we are using codes of WANL. In other cases we are not. AGr 1 s not developirg nuclear codes. Wo're taking the information of ot ners and ucing it. 
Q. Are you using WANL information and extrnding it to non-nuclear component $\leqslant$ ?

A. $Y \in s$. We are careful to avoid duplication of any work WANL does.

Q. What is your estimate of the percent of time applied to integration effort of the overail. system versus review and monitoring of WANL?

A. Nc Iess than one haif is integration (including program planning in this category).

Q. What did you do "in-house" on the cementing of fuel elements program?

A. We did three or four analyses on the advantages for clusters.

Q. Ary ctmeniling work?

A. On.y $r \in l a t, e d$ to fastening of strain gages on graphite. A long time zgo, prior to INRVA, we did some work on cempnting of graphite componerts.

O. Was ary done in the last year?

4. To. Filel eienent instrumentation installation was worked on under Subtask 2.4 .

Q. WLI you please review briefly your personnel buildup?

A. In Oetober lg6e the original staff was four people. There has been neariy a linear buildup to roughly twenty. The peak month was either june or July 1963 due to utilization of fabrication and sest people or the kutton progrsm.

Q. Wers $r^{2}-s^{2} I^{+}=$of IASL and AGC on the button program comparable?

A. This was on B4C. LASI didn't perform the same type of investigation. LASL requested AGC to do tbis.

Q. What doclmertation covers this work?

A. An inturral AGC memo describes this investigation. The content can be made avajlabis if you wish.

Q. Tezi us more about the organizational buildup.

A. We had four in October 1962 and twenty in September 1963. The majority rame on voari in Apr.I, May and June. They became effective in June, Jilly orid Aigdet. 
Q. Separately, from this meeting, we'd I lke to explore the organization and subgroup assignments on Subtask 1.03.

Q. Regarding program plans submitted by REON, these contain WANL portions. We know there may have been revisions to WANL o original submission. Did WANL respond consistently with the original guidelines?

A. No. The initiaI WANI submittal for the CY 1964 program and the finaI WANL submittal differed significantly on numbers of reactors and test schedules.

Q. It makes It difficult for SNFO-C to anaiyze when a.1. the inputs from WAIN ore not received.

Q. WANic arrived at a conclusion on the schedule two to three weeks ago wrich could have been arrived at sooner. There was no administrative flaid In wht has taken place in the guidelines and response to them.

Q. Whas there any work done "in-house" at Aerojet related to WANI assigned Efiort?

A. There was stuly work related to the support plate for the reactor. A pre Liminary investigation was made based on a forged plate design.

Q. Was experinental work performed?

A. Srus work was done with a lucite model plus some early enalyses.

W. Has WAlNI haa the berefit of Internal AGC work?

A. WAIJ 195 reenived the content of any AGC investigation by incorporation into letters to WAN or discussions with WANL.

Q. IE AGO in series on any WANL effort?

A. No, uriess incorporation or integration is required with other than WANL input.

Q. Can SNEO have information which is in the many internal reports referred to?

A. yes。W- li make copies available to you.

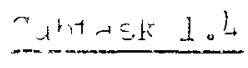

Q. 1t is stated that design is complete and brazing development conplete. There dre real. problems here and issuance or a first, drawing jo perthes: only $1 \%$ of completion. More drawings are needed as fabrication proceci.: Somoor = not ciose to the program could get an incornect impression thot. the job is dore. 
A. This is true, additional cycles are re luired. The intent of the presentation chart was to relate to the completion of the step or iteration pianned. For instance, brazing development program is a continuing effort (Applied Research). "Completion" here means that the CY 63 portion was finished.

Q. It IE ${\mathrm{s}^{+}}^{+}$ed that wonduct of Hybrid NERVA Noy Le, ACFI Pressure VEsst. structural Test, wa reported in March. SNPO-C actually received a report last treek.

A. mrree (3) ropies of the internal AGC test report R-C6415 issued 22 Nar-n 196; were sent to SNPO-C on 1 May 1963. The final report, tae NERI hyarostatic Test St maturai Evgluation Report, Report No. 8207-6; -9. AGC No. 10662 was serit to SNPO-C on 23 October 1.963.

w, Wher ar = the the 1j-Tub= $20 \geq 11=5$ to be complete?

4. Jarisacy $196+$ and February 1964.

Q. What is t re rollatior effects information on $7^{+}$anium? This status report says the material evaluation is complete.

A. Thi -rork 1 dorte under Subtask 1.9 and is Eeparate.y reported.

Q. Fadiztion rifezts tork is furded under 1.4, tested in 1.9.

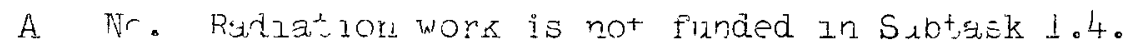

Q. Ningt were "it Elans for tre NERWI na/zZns?

A. Trey whe duvertril to drvelopmentg. purposes.

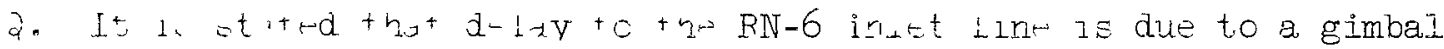
"nel" in $r=b^{1+} \mathrm{l}^{+} \mathrm{i}^{+}$is duf to a hinge joint.

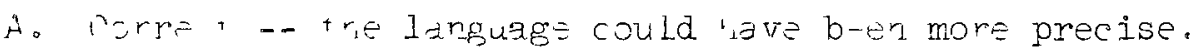

Q. Thu fPNTS deliy is stated to be part 1 y due "o the "H" area window.

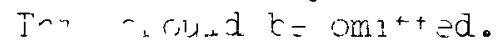

A. $\Gamma^{2}=$ primary driay ls due to lack of nardwort as staled.

Q. Inje tor development tests have beer run for two years on 30 . Any progres=?

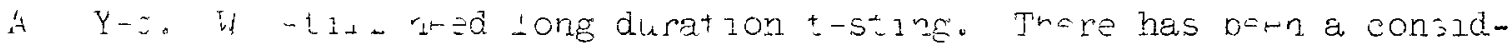
rat t im- p-rucd mat reladively few trsts.

k. Dus to 'zo of hardware couldn't get more $\mu_{0^{+}}$? ? 
A. Due to lack of NERVA nozzles and emphasis on nozzle fabrication, we completedr- planned work with XIR8T nozzles.

Q. Are you getting over the hump?

A. We will have the proof when we test. We have redesigned and expect improvement in interface cooling, outer Channel. (Steel) erosion problems.

Q. Which one of the twenty-seven nozzles fabricated will be used on NRXA-1 t,est?

A. The twenty-seven are equivalents, not specific completed nozzles. Trey include tiwenty-two in process of fabrication or completed, long lead materials procured for five, and five nozzles stripped and recast. For NRX-A-1 nozZle S/N 0000011 is prime S/N 0000010 backup. For NRX-A-2 nozzle $\mathrm{S} / \mathrm{N}$ oono0l2 is prime $\mathrm{S} / \mathrm{N} 0000007$ backup.

Gubtisk 1..5

Q. Do experimental data show that magnetic amplifiers will work in a reäiation environment?

A. Yes.

Q. Regarding remote engine controls, what were the obligations in this contrsot year?

A. It was intended from early in the program to take simulation far enough to prepare design criteria for ETS-l remote engine control system. We left in only the effort to complete simulation hardware.

Q. Regarding the 100-hour GTR test, how are the flux rates versus those expected in NERVA?

A. We believe we are OK above the shield. We have simulated NERVA conditions to the best of our ability except the heating due to the IPCV.

qu. Are design and development of amplifiers complete?

A. Yes -- tr, rough experimental models.

Q. Satisfaction with the amplifier design is indicated, but your reports on rajiation tests indicate that magnetic amplifiers do not work well. ir a radiation field.

A. The lost anplifien radiaticr tests mun just recently put some fifty hours on them and indicate that the amplifiers operate satisfactorily. The radiation test that you may have been concerned about was a test. rur sometime in August wherein the amplifier design was such that 
certain elements were not properly heat-sinked. As a result, improper operation was due to temperature effects. The designs tested recently in the GTR have corrected this design defect and, hence, the amplifiers work well within specifications.

Q. Suggest $N$. Irvine and A. Hintze get together on any further detail questions.

Subta.sk 1.6

Q. What was the cause of Vallecitos delay?

A. Primarily an impasse on fee and contract provisions in placing the subcontract.

Q. The "draft report" shown in the presentation chart indicates it includes much summary information. Is this considered complete even though SNPO-C hasn't seen the detail?

A. We had no contractual requirement for a report but all the information is available to SNPO-C.

Subtask 1.7

Q. What is preliminary design?

A. In tinis case it includes basic layout, component criteria;schematics, etic., so that detail design can proceed.

Q. You have said all milestones were complete yet the milestone chart disagrees. How come?

A. Our error. As stated by the milestone chart, there vere two milescones deferred.

Subtask 1.9

Q. The redirection regarding the dewars is a matter of interpretation.

Q. One ares where the most trouble has developed is in the 501, 502, 503 series of radiation effects pallets. Why were they so late in getting tested?

A. We would like to prepare a detalled answer on this item. 
Subtask 2.1

Q. You've indicated completion of preliminary design on the NES duct trailer. How far along is the fabrication of the OPS, EIV and MCC?

Q. Understand meeting set for 5-6 November with AMF to get this status.

A. Procurement of long lead hardware was initiated five months ago for a.11 of these.

Q. Reference to the number of WANL items complete doesn't mean one hundred percent completion of all WANL items of work does it?

A. No. The actual number of WANL items completed has been presented in the WANL presentation of last week.

Q. Will the duct transporter be available for the sheet metal duct testing?

A. No.

Q. The additional work listed regarding providing NRX equipment for E-MAD was $r e a l l y$ always contemplated wasn't it?

A. It was always contemplated but the amount of work performed in Contract Year 1963 was significantly more than planned.

Subtask 2.4

Q. Were milestones 25 and 26 complete?

A. Yes. They are shown in the Instrumentation Data Book. The evaluation report has not been written.

Q. What is the proof testing referred to in the Instrumentation Data Book?

A. Only proof testing is per manufacturer's specifications. No testing is done by us. We are trying to buy as much as possible off-the-shelf instrumentation. Testing will be done on this program before commitment to NRX. Data from testing on another program may be acceptable.

Q. You have referred to procurement status reports. Have such been sent to SNPO-C?

A. Yes。

Q. In the development program SNPO-C approval requirements exist yet woris is being accomplished.

A. There is a problem here but this discussion should be deferred.

Q. You say you have run qualification tests for all NRX instrumentation. 
A. No. Just for the second objective. We are buying conmercial instrumentation and trying to get improvements working with manidfacturers. Proof testing finds the limitations of the instrumentation. This is "type-testing." One uses the information to go back to the manufacturer and it give guidance as to whether or not we can use the instrument. Qualification testing (which we are not performing) involves imposing an exact environment then keep testing until the instrument meets the requirements under this exact environment. We have only set the goals so far.

Q. There are a number of other detail questions on measurement requirements, accuracies, etc., which are important and should be answered but can be handled outside this neeting.

Q. How do we stand on NRX-A-2?

A. Mary instrumentation components have not yet been procured or qualified. Procurement had been postponed to take advantage of results of latest radiation effects tests.

Q. You've stated that accuracy of $\pm .05^{\circ} \mathrm{R}$ has been achieved. If tmie, this is a major improvement.

A. We did accomplish this and agree it is a significant advance.

Q. Do you feel comfortable with temperature control?

A. Instrumentation for temperature control for NRX-A2 has not yet been developed to meet control system specifications. While this will. not delay the NRX-A2 test, the control system may require a degraded periomance level. Further analysis of the control. system will give us a detailed answer as to possible lower performance.

A. We are not confortable regarding control of temperature within a radiation field.

Q. When do you have to decide on instrumentation for INRA-2 and. initiate procurement?

A. One to two months. There should be six months lead time from the test.

Q. Insirunentation alternatives may have differing mounting requirersents or affect other components. It is not known what instrumentation is t.o be used in the control system. Why don't you decide -- and then go ahear and buy it?

A. We have been waiting for the test schedule to settle down and taking advantage of latest known information on instmumentation. It is cles.r that the final instrumentation decision dates for NRXA-2 are nearly upor us and we will get together with SNPO-C task engineers and review lead uimes and what actions will be taken. 
Subtask 2.6

Q. What use is made of IASL logs?

A. WANL uses this information in designing the reactor and in reliability analyses.

Q. How did you develop mathematical models for predicting reliability of the engine and non-nuclear components?

A. The model for the reliability of the engine is based on the product law of statistics since the functional blocks of the apportionment diagram were selected so as to be series functions. The models for the components or functional blocks vary, depending upon the test data to be generated. These models are based on normal distributions, exponential aistributions, margins of safety, etc. as applicable.

Q. What operational data would be used?

A. For non-nuclear components, test data on Titan and other programs were used for reliability apportionment and prediction. In using these data, charges in envirorment and operating conditions were considered.

Q. Who is responsible for damage due to handling? How can this be prevented?

A. Responsibility for handling damage is shared among several groups. Design engineering is responsible for designing a product, which is least susceptible to damage. Manufacturing is responsible for providing adequate tooling and handling equipment, the preparation of handling procedures, and for the physical handling. Quality Control is responsible for reviewing handling procedures and for implementing corrective action. All of the above activities require improvement to prevent handiing damage.

Q. It is understood that items have been fabricated from drawings not checked by stress and Quality Control.

A. It is INERVA policy that all drawings be checked for stress and quality control requirements prior to procurement or fabricasion. On the modification of the No. 10 nozzle, permission was granted to use sketches ratber than released drawings, but the requirements for stress and quality control checks were not waived.

Q. AGC engineers were stjll considering three lnicknesses of quartz glass for a nozzle window. This should nave been established on the sketch or drewing by stress analysis.

Q. (BJ AGO) Does SINPO-C consider there was a deficiency? Was the procedure fauity?

A. (By SNPO-C) The procurement as agreed to Uy SIVEO-C was satisfactory or it would not have been approved. This incident was related to a calculated risk on the thickness of the glass. 
Q. The milestone charts indicate completion showing design review by Reliability. What evidence exists that these were done?

A. Milestone No. 4 was completed by WANL, but no formal report has been received by REON. Milestone No. 5 was completed by Bendix during CY 1963. The report on this review will be issued on 21 November 1963 in Report No. BPAD-863-4-15158R. Milestone No. 7 was completed by LRP, and a report has been issued by Memo No. 897 dated 28 August 1963. This report may be found in the Reliability Data Book in the Miscellaneous Section, No. 9999. A meeting of AGC and SNPO-C counterparts can explore this further if desired.

Subtask 2.8

Q. How many people were put through the entire training program?

A. One series of training was completed by twenty-eight people。

\section{Subtask 3.1}

Q. Is the scale model testing program completed for the ETS-I duct?

A. No. The testing to date established the design operating point. Testing in CY 64 would be conducted to define the operating map of IES and for various interrelations of seal leakage, turbine flow, purge flow and nozzle area ratio and position.

Subtask 4.1

Q. When was the first time you had a computer run on NRXA-I status and called together the responsible people to review it?

A. About two to three months ago we got our first computer run on a good integrated network and had review with responsible parties.

Q. Does WANL receive your evaluation of the overall NRXA-1 status?

A. Yes. There are various means of providing this but the most effective is via the Task Force. This group meets every two weeks.

Q. Does the NERVA Test Operation contribute directly to the integrated demanä networks?

A. The input to the integrated demand networks comes via the NRX Task Force nembers which include the NTO.

Q. To set up $a$ demand net, you need the pecple at NTO to give their input directly。 
Q. Have there been no meetings to review PERT work?

A. There is constant daily phone communication among the participants. There are weekly meetings at LRP. There are REON composite meetings with WANL and IRP. We are not at present involving the top level REON WANL management in these meetings.

A. In the near future a number of top REON management personnel will be indoctrinated into the Navy Polaris management system which provides for weekly overall program status reviews. These concentrate on performance, schedules and cost. AIl critical areas are reviewed and correcutive actions to.ken.

Q. Th1s is most interesting; Could one or two SNPO-C personnel attend the briefing in Washington on this system?

A. Yes, they are invited.

قubtask 4.4

a. Is there Jocumentation as to what the central data system will do?

A. There was a preliminary cxiteria report issued in June. It is noted in the bibliography.

Q. It needs to pick up Quality Control and Reliability data, support equipment provisioning lists, etc.

A. The criteria will be updated.

Sucta.sk 4.5

Q. The chart indicates an accountability system for Government property. Where is a comparable requirement for other subcontractors and AGC plants other than REON?

A. The entire nateriel functions under Contract SNP-1 are the responsibility of the REON Subcontracts Division. This includes accountability for Gorernment property and a system has been established applicable to aII AGC plants involved. with NERVA work as well as to subeontractors.

Q. What subcontractor's heve received approvel of their procurement policy ard procedures?

A There has been continuing review of all subcontructors' procurement, systcms with the objective of getting them upgraded to the extent approval can be sranted of the "procurement systems." This wouid perrit raising approval limits by both AGC and SNPO-C of suicontractor" procurement packages. Improvements are being maje but to date no increases in procurement approvel levels have been granted. This would regrire ioint SNPO-C and Aerojet concurrence. 


\section{Subtask 5.3}

Q. Regarding H-6 area slippage of activation from 25 October to April 1964, how much of this is due to delays by Linde and how much just genera.l slippages?

A. The original date for H-6 activation was 17 April 1963. This was moved to 1 June to accomodate the directed Pressure Fed Nozzle Test System conversion. It was moved to August as a result of Linde delay. Concurrentily utilized this time to incorporate changes due to the Cold Flow Test and cycle changes. We could have saved ninety days except for Linde - we took advantage of the time however.

Q. What is the end date of activation?

A. The date we inu the first test.

Q. How confident are you of the 26 December activation date for $\mathrm{H}-4$ ?

$A$. Intil three days ago we were confident. Now we have a report that the December date is in jeopardy due to late delivery of gimbal joints. Probably now moves us into the first of 1964 although there is some chance for recovery.

Q. Does deiry of $\mathrm{H}-4$ mean delay of $\mathrm{H}-6$ ?

A. Yes。 Due to labor problems we are kept off both stands simultaneously.

\section{Costs and. Istincite to Complete}

Q. Do the toten is on the cost sheets include costs of subcontractors such as $A M F$ and Bendix?

A. Yes. The costs shown include all Aerojet costs plus all subcontractors except WANL. Costs for WANL are shown in summary on the chart entitled SINF-I Cost Summary, The details of WANL costs were presented at Pittsburgh on 22-23 Ostober.

Q. On Subtask 1.9, the costs shown for Mod 8 vary from those indicated in the total column.

A. This is an error and it will be corrected. The $\$ 35,000$ difference is due to an exroneous jnclusion from Contract Year 1962.

Q. There nay be need of some further breakdown of committed costs to be incurred arter Contract Year 1963. We car get together later on this.

A. Yes. If you will advise what additional information is required, we will. see that it is provided。 